UNIVERSIDADE DE SÃO PAULO

INSTITUTO DE FÍSICA

\title{
EMISSÕES VEICULARES EM SÃO PAULO: QUANTIFICAÇÃO DE FONTES COM MODELOS RECEPTORES E CARACTERIZAÇÃO DO MATERIAL CARBONÁCEO
}

DJACINTO APARECIDO MONTEIRO DOS SANTOS JUNIOR

Dissertação apresentada ao Instituto de Física da

Universidade de São Paulo para obtenção do título de Mestre em Ciências.

\section{Orientador:}

Prof. Dr. Paulo Eduardo Artaxo Netto

\section{Banca examinadora:}

Prof. Dr. Paulo Eduardo Artaxo Netto (IF-USP)

Profa. Dra. Maria de Fátima Andrade (IAG-USP)

Prof. Dr. Eduardo Landulfo (IPEN-USP) 


\section{FICHA CATALOGRÁFICA}

\section{Preparada pelo Serviço de Biblioteca e Informação do Instituto de Física da Universidade de São Paulo}

Santos Junior, Djacinto Aparecido Monteiro dos

Emissões veiculares em São Paulo: quantificação de fontes com modelos receptores e caracterização do material carbonáceo. São Paulo, 2015.

Dissertação (Mestrado) - Universidade de São Paulo. Instituto de Física. Depto. Física Aplicada

Orientador: Prof. Dr. Paulo Eduardo Artaxo Netto

Área de Concentração: Física Atmosférica

Unitermos: 1. Poluição atmosférica; 2. Aerossóis atmosféricos; 3. Aerossóis carbonáceos; 4. Modelos receptores; 5. Emissões veiculares. 


\section{AGRADECIMENTOS}

Agradeço ao Prof. Dr. Paulo Artaxo pela orientação, pelo incentivo e por propiciar excelentes condições de trabalho.

Ao Joel Ferreira Brito, pela coorientação extremamente atenciosa e fundamental para o desenvolvimento deste trabalho.

A Ana Lúcia Loureiro e Andrea Arana pela enorme colaboração nas análises feitas em laboratório.

A toda a equipe do LFA, Alcides Ribeiro, Fernando Moraes, Fábio Jorge, Simara Moraes, pelo apoio técnico durante todo o desenvolvimento deste trabalho.

Aos verdadeiros, que tanto me apoiaram e de alguma forma contribuíram para que eu chegasse até aqui, Gilberto, Dennis, Baiano, Tio Punk, Brunão, Thiagão, Naco, Fernando, Dentinho, Ivanildo e Ataide.

Aos meus pais, Djacinto e Graça, pelo apoio, pelo carinho e por estarem, mesmo longe, presentes o tempo inteiro na minha vida.

Ao Gustavo, meu irmão, por ser uma grande motivação para mim. Em meio aos enormes orgulhos que você me dá, dedico este trabalho a você.

A Bruna Salgueiro, por estar ao meu lado durante esses anos tão difíceis, pelo companheirismo, pelos sorrisos e pela força. 

“Cada obstáculo é uma missão e eu anuncio: É isso ai você não pode parar Esperar o tempo ruim vir te abraçar Acreditar que sonhar sempre é preciso É o que mantém os irmãos vivos" Racionais Mc's - A vida é desafio 



\section{RESUMO}

A significativa emissão veicular na Região Metropolitana de São Paulo (RMSP), com mais de 7 milhões de veículos e uma população da ordem de 18 milhões de habitantes, fazem desta uma área crítica do ponto de vista de níveis de poluentes atmosféricos. Neste trabalho foi obtida a determinação quantitativa de fontes de poluentes atmosféricos na RMSP, em particular do material carbonáceo na fração fina $\left(\mathrm{PM}_{2.5}\right)$ do aerossol atmosférico, focando na componente veicular. Como parte do projeto FONTES, coordenado pela Petrobrás, PUC-Rio e IFUSP, foram operadas por 1 ano quatro estações de amostragem localizadas em Congonhas (CGH), Ibirapuera (IBP), Cerqueira César (FSP) e Instituto de Física da USP (IFP), no período entre agosto de 2011 e janeiro de 2014. A concentração em massa de material particulado fino $\left(\mathrm{PM}_{2.5}\right)$, grosso $\left(\mathrm{PM}_{2.5}\right.$ $\left.{ }_{10}\right)$, e inalável $\left(\mathrm{PM}_{10}\right)$ foi determinada através de análise gravimétrica. Íons solúveis foram determinados por cromatografia iônica (IC), elementos traços por fluorescência de raios-X (XRF) e as concentrações de black carbon equivalente por refletância ótica. As componentes de carbono orgânico (OC) e carbono elementar (EC), bem como as diversas frações carbonáceas foram determinadas por análises termo-ópticas em equipamento da Sunset Inc., seguindo vários protocolos analíticos. As concentrações de gases tais como $\mathrm{CO}, \mathrm{NO}_{\mathrm{x}}$, e $\mathrm{O}_{3}$ foram fornecidas por estações de monitoramento da CETESB. Modelos receptores tais como APFA (Absolute Principal Factor Analysis) foram usados na determinação quantitativa de fontes de poluentes.

Observou-se uma grande similaridade nas concentrações medidas nas estações, indicando uma homogeneidade nas concentrações e composição de aerossóis da moda fina $\left(\mathrm{PM}_{2.5}\right)$ na RMSP. Nas estações amostradoras IFP, FSP e IBP foram observadas concentrações entre $10 \mathrm{e}$ $12 \mu \mathrm{g} \mathrm{m}^{-3}$ na fração fina e na faixa de 16 a $18 \mu \mathrm{g} \mathrm{m}^{-3}$ na fração grossa. Em CGH, observou-se uma concentração média de $34 \mu \mathrm{g} \mathrm{m}{ }^{-3}$, para $\mathrm{PM}_{10}$. O balanço químico de massa mostrou, na fração fina, impacto predominante de aerossóis orgânicos ( 50\%), EC ( 20\%) e sulfato ( 20\%). $\mathrm{Na}$ fração grossa verificaram-se concentrações dominantes de aerossóis de poeira do solo $(\sim 40 \%)$. A APFA identificou e quantificou o impacto das componentes veicular ( 60\%), ressuspensão de solo ( 10\%), emissões industriais e de sulfato ( 20\%), aerossol marinho ( $\sim 5 \%)$ e aerossol secundário $(\sim 5 \%)$. O impacto da componente veicular é dominante na RMSP. A aplicação dos modelos receptores forneceu a caracterização do material carbonáceo de acordo com as fontes de emissões e um perfil de volatilidade do material carbonáceo. 


\begin{abstract}
The large vehicle fleet in the Metropolitan Region of São Paulo (RMSP), with more than 7 million vehicles and a population of about 18 million people, make this a critical area from the point of view of atmospheric pollutants levels. This work focused on the quantitative determination of air pollutant sources, focusing at the vehicular component and the carbonaceous material in the fine fraction (PM2.5) of the atmospheric aerosol of RMSP. As part of the FONTES research project, coordinated by Petrobrás, PUC-Rio and IFUSP, it was operated for 1 year four sampling stations located in Congonhas (CGH), Ibirapuera (IBP), Cerqueira César (FSP) and the Institute of Physics at USP (IFP) during the period from August 2011 to January 2014. The mass concentrations of fine $\left(\mathrm{PM}_{2.5}\right)$, coarse $\left(\mathrm{PM}_{2.5-10}\right)$ and inhalable $\left(\mathrm{PM}_{10}\right)$ particulate matter was determined by gravimetric analysis. Soluble ions were determined by ion chromatography (IC), trace elements by X-ray fluorescence (XRF) and equivalent black carbon (EBC) concentration by optical reflectance. The organic carbon (OC) and elemental carbon (EC) components, as well as several carbonaceous fractions were determined by thermo-optical analysis using a Sunset Inc. equipment, following various analytical protocols. The concentration of gases such as $\mathrm{CO}, \mathrm{NO}_{\mathrm{x}}$, and $\mathrm{O}_{3}$ were obtained from CETESB air pollution monitoring stations. Receptors models such APFA (Absolute Principal Factor Analysis) were used for the quantification of the impacts of polluting sources. It was observed similar concentrations in the several sampling stations, showing uniformity in the concentrations and aerosol composition of $\mathrm{PM}_{2.5}$ in the RMSP. For the sites IFP, FSP and IBP were observed concentrations between 10 and $12 \mu \mathrm{g} \mathrm{m}^{-3}$ in the fine fraction and in the range from 16 to $18 \mu \mathrm{g} \mathrm{m}^{-3}$ in the coarse fraction. In the CGH site, there was an average concentration of $34 \mu \mathrm{g} \mathrm{m}^{-3}$ of $\mathrm{PM}_{10}$. The chemical mass balance showed large presence of organic aerosols ( $\sim 50 \%)$, EC ( 20\%) and sulfate ( 20\%) in the fine mode fraction. In the coarse fraction soil dust aerosols $(\sim 40 \%)$ dominates. The APFA identified and quantified the impact of vehicular components ( 60\%), soil dust ( 10\%), industrial emissions and sulfate ( 20\%), marine aerosol $(\sim 5 \%)$ and secondary aerosol $(\sim 5 \%)$. Vehicular emissions is the major air pollution component at the RMSP. The application of receptor models has provided the source characterization of carbonaceous material according to their volatility profile.
\end{abstract}




\section{Índice de figuras}

Figura 1-1 - Esquema idealizado da distribuição da área de superfície de aerossóis atmosféricos indicando modas principais, fontes e mecanismos de formação e remoção das partículas. 18

Figura 1-2 - Visão geral das fontes de emissão primária de black carbon e processos que controlam a sua distribuição na atmosfera ........................................................................ 23

Figura 1-3 - Distribuição geográfica das megacidades ...................................................... 26

Figura 1-4 - Região Metropolitana de São Paulo (RMSP). ................................................... 27

Figura 1-5 Efeitos da inalação de poluentes atmosféricos na saúde humana ............................ 31

Figura 1-6 - A deposição de partículas no trato respiratório humano ....................................... 32

Figura 1-7 - Estimativas de emissão relativa dos diversos poluentes por tipos de fontes............ 36

Figura 3-1 - Localização das estações amostradoras do projeto FONTES na Região

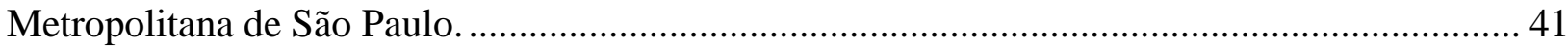

Figura 3-2- Fotografia mostrando os estágios do amostrador do particulado fino e grosso......... 43

Figura 3-3 - A medida de "equivalent black carbon" (EBC) foi feita no reflectrometro da

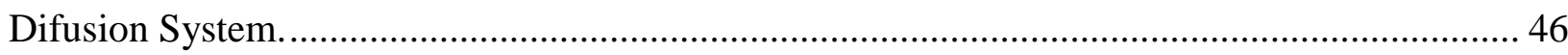

Figura 3-4- Ilustração do espectro de cromatografia iônica com a análise de cátions e ânions do equipamento Dionex ICS-3000 mostrado à direita nesta figura............................................. 47

Figura 3-5 - Processo em que as partículas emitem raios X por fluorescência.......................... 48

Figura 3-6- Esquema geral do princípio de funcionamento da análise por fluorescência de raios$\mathrm{X}$ de dispersão de energia - Energy Dispersive X-Ray Fluorescence. (EDXRF)...................... 49

Figura 3-7 - Espectrômetro de Fluorescência de raios X - Epsilon 5 (PANalytical) ................. 49

Figura 3-8 - Diagrama esquemático de funcionamento do analisador termo-óptico.................. 51

Figura 3-9 - Exemplo de termograma para uma amostra coletada na estação de Congonhas ..... 52

Figura 4-1 Série temporal da concentração em massa do material particulado inalável discriminado nas frações fina e grossa, no Ibirapuera, no período de Agosto de 2011 a Novembro de 2013.

Figura 4-2 Série temporal da concentração em massa do material particulado inalável discriminado nas frações fina e grossa, na estação IFP, no período de Outubro de 2011 a Novembro de 2013.

Figura 4-3 Série temporal da concentração em massa do material particulado inalável discriminado nas frações fina e grossa, em Cerqueira César, no período de Abril de 2012 a Janeiro de 2014. 
Figura 4-4 Série temporal da concentração em massa do material particulado inalável, dado pela soma das frações fina e grossa, em Congonhas, no período de Agosto de 2011 a Novembro de 2013. 68

Figura 4-5 - Regressão linear entre as medidas de material particulado PM10 feitas pela CETESB e pelo LFA-IFUSP para a estação amostradora de Congonhas. 70

Figura 4-6 - Regressão linear entre as medidas de material particulado PM10 feitas pela CETESB e pelo LFA-IFUSP para a estação amostradora Ibirapuera. 70

Figura 4-7 - Regressão linear entre as medidas de material particulado PM10 feitas pela CETESB e pelo LFA-IFUSP para a estação amostradora Cerqueira César. 70

Figura 4-8 - Regressão linear entre as medidas de material particulado PM10 feitas pela CETESB e pelo LFA-IFUSP para a estação amostradora do IFUSP. 70

Figura 4-9 Concentrações elementares médias identificadas na moda fina em IBP, IFP e FSP por XRF. Gráfico em escala logarítmica. 71

Figura 4-10 Concentrações elementares médias identificadas na moda grossa em IBP, IFP e FSP por XRF. Gráfico em escala logarítmica.

Figura 4-11 Composição elementar média do PM10 para as quatro estações. Elementos com concentração acima de $100 \mathrm{ng} \mathrm{m}^{-3}$. 73

Figura 4-12 Composição elementar média do PM10 para as quatro estações. São listados os elementos traços com concentração abaixo de $100 \mathrm{ng} \mathrm{m}^{-3}$. 73

Figura 4-13 Composição iônica média da fração fina para IFP, FSP e IBP determinada por IC. Gráfico de barras em escala logarítmica. 74

Figura 4-14 Composição iônica média da fração grossa para IFP, FSP e IBP determinada por IC. Gráfico de barras em escala logarítmica. 75

Figura 4-15 - Regressão linear entre os resultados obtidos por XRF (enxofre elementar) e IC (íon sulfato) nas frações fina e grossa para a estação amostradora do Ibirapuera. 76

Figura 4-16 - Regressão linear entre os resultados obtidos por XRF (enxofre elementar) e IC (íon sulfato) nas frações fina e grossa para a estação amostradora do IFUSP. 77

Figura 4-17 - Regressão linear entre os resultados obtidos por XRF (enxofre elementar) e IC (íon sulfato) nas frações fina e grossa para a estação amostradora Cerqueira César. 77 Figura 4-18 Série temporal da concentração em massa de black carbon equivalente discriminado nas frações fina e grossa, na estação amostradora do Ibirapuera, no período de agosto de 2011 a novembro de 2013. 80

Figura 4-19 Série temporal da concentração em massa de black carbon equivalente discriminado nas frações fina e grossa, na estação amostradora do IFUSP, no período de outubro de 2011 a novembro de 2013. 80 
Figura 4-20 Série temporal da concentração em massa de black carbon equivalente discriminado nas frações fina e grossa, na estação amostradora de Cerqueira César, no período de abril de 2012 a janeiro de 2014

Figura 4-21 Série temporal das concentrações de carbono orgânico e elementar na estação amostradora do Ibirapuera, no período de Agosto de 2011 a Novembro de 2013. 83

Figura 4-22 - Série temporal das concentrações de carbono orgânico e elementar na estação amostradora do IFUSP, no período de Outubro de 2011 a Novembro de 2013. 84

Figura 4-23 - Série temporal das concentrações de carbono orgânico e elementar na estação amostradora de Cerqueira César, no período de Abril de 2012 a Janeiro de 2014. 84

Figura 4-24 - Série temporal das concentrações de carbono orgânico e elementar na estação amostradora de Congonhas, no período de Agosto de 2011 a Novembro de 2013.

Figura 4-25 Balanço de massa químico para o material particulado fino na estação amostradora de Cerqueira César. Em colunas empilhadas estão as contribuições das componentes do balanço. Em linha a concentração do $\mathrm{PM}_{2.5}$ medido.

Figura 4-26 - Balanço de massa químico para o material particulado fino na estação amostradora do Ibirapuera. Em colunas empilhadas estão as contribuições das componentes do balanço. Em linha a concentração do $\mathrm{PM}_{2.5}$ medido. 88

Figura 4-27 - Balanço de massa químico para o material particulado fino na estação amostradora do IFUSP. Em colunas empilhadas estão as contribuições das componentes do balanço. Em linha a concentração do $\mathrm{PM}_{2.5}$ medido. 88

Figura 4-28 - Concentração média das nove frações carbonáceas discriminadas para as quatro estações amostradoras do projeto FONTES.

Figura 4-29 - Concentração média das frações carbonáceas discriminadas para o conjunto de dados das estações amostradoras IFP, IBP e FSP. Concentrações calculadas para os meses de inverno (Maio, Junho, Julho e Agosto) e verão (Novembro, Dezembro, Janeiro e Fevereiro).... 93 Figura 4-30 - Regressão linear entre as concentrações de black carbon equivalente na fração fina e de carbono elementar para a estação amostradora do Ibirapuera 94 Figura 4-31 - Regressão linear entre as concentrações de black carbon equivalente na fração fina e de carbono elementar para a estação amostradora de Cerqueira César. 94 Figura 4-32 - Regressão linear entre as concentrações de black carbon equivalente na fração fina e carbono elementar para a estação amostradora do IFUSP. 94

Figura 5-1 - Atribuição de fontes do material particulado fino para a estação amostradora IBP. 100

Figura 5-2 Atribuição de fontes para o material particulado fino na estação amostradora IFP.. 105 
Figura 5-3 Atribuição final de fontes do material particulado fino para a estação amostradora Cerqueira César. 108

Figura 5-4 Atribuição final de fontes do material particulado fino para o conjunto de dados das estações IFUSP, Cerqueira César e Ibirapuera.

Figura 5-5 - Série temporal das concentrações de $\mathrm{PM}_{2.5}$ atribuídas às emissões veiculares na APFA com cinco fatores para o conjunto de dados das estações IFP, FSP e IBP no período de agosto de 2011 a janeiro de 2014

Figura 5-6 - Série temporal das concentrações de $\mathrm{PM}_{2.5}$ atribuídas à ressuspensão de poeira do solo na APFA com cinco fatores para o conjunto de dados das estações IFP, FSP e IBP no período de agosto de 2011 a janeiro de 2014 .

Figura 5-7 - Série temporal das concentrações de $\mathrm{PM}_{2.5}$ atribuídas a aerossóis de sulfato/emissões industriais na APFA com cinco fatores para o conjunto de dados das estações IFP, FSP e IBP no período de agosto de 2011 a janeiro de 2014.

Figura 5-8 - Série temporal das concentrações de $\mathrm{PM}_{2.5}$ atribuídas ao aerossol marinho na APFA com cinco fatores para o conjunto de dados das estações IFP, FSP e IBP no período de agosto de 2011 a janeiro de 2014.

Figura 5-9 - Série temporal das concentrações de $\mathrm{PM}_{2.5}$ atribuídas a aerossóis orgânicos secundários na APFA com cinco fatores para o conjunto de dados das estações IFP, FSP e IBP no período de agosto de 2011 a janeiro de $2014 .$.

Figura 5-10 - Contribuição média dos cinco fatores principais para a concentração de material particulado fino referente ao conjunto de dados das estações IBP, FSP e IFP, para os meses de inverno (Maio, Junho, Julho e Agosto) e verão (Novembro, Dezembro, Janeiro e Fevereiro). . 115

Figura 5-11 Atribuição de fontes do material particulado carbonáceo para o conjunto de dados das estações IFUSP, Cerqueira César e Ibirapuera.

Figura 5-12 - Concentrações de formiato medido na fração fina e da fração mais volátil de carbono orgânico (OC1) para o conjunto de dados das estações amostradoras IBP, IFP e FSP no período de agosto de 2011 a janeiro de 2014.

Figura 5-13 - Concentrações de sulfato medido na fração fina e da fração menos volátil de carbono orgânico (carbono pirolítico ou PC) para o conjunto de dados das estações amostradoras IBP, IFP e FSP no período de agosto de 2011 a janeiro de 2014. 


\section{Sumário}

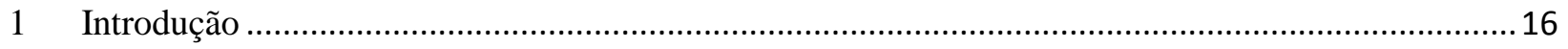

$1.1 \quad$ A atmosfera terrestre .................................................................................................. 16

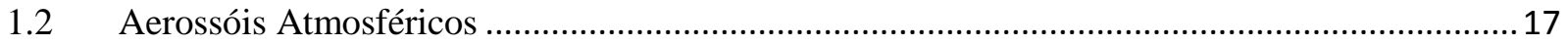

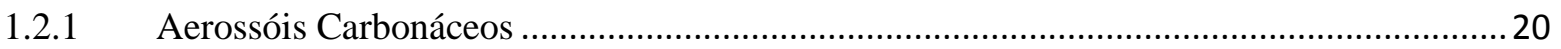

1.3 A poluição do ar em ambientes urbanos ……………………………………………………....2 23

1.3.1 Principais Poluentes Atmosféricos: Os Padrões de Qualidade do Ar .................................24

1.3.2 São Paulo - Megacidade de impacto global …………………………………………....2

1.4 Efeitos da poluição do ar à saúde humana ..............................................................................2

1.4.1 Os Padrões de Qualidade do Ar ..................................................................................

1.5 Estimativas de emissão de poluentes atmosféricos na RMSP ……………………………….....35

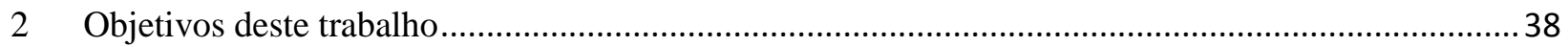

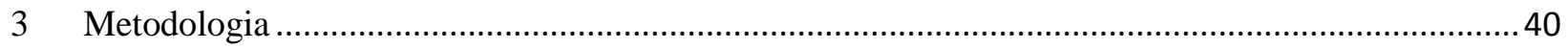

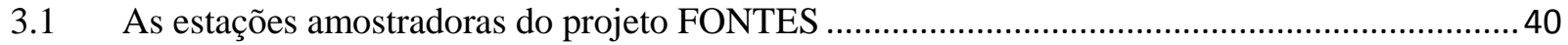

3.1.1 Estação amostradora de Congonhas (CGH) .................................................................... 41

3.1.2 Estação amostradora de Cerqueira César - Faculdade de Saúde Pública (FSP).................. 41

3.1.3 Estação amostradora do Ibirapuera (IBP) ................................................................. 42

3.1.4 Estação amostradora Instituto de Física da USP (IFP) …………………………………. 42

3.2 A coleta do material particulado ...................................................................................... 42

3.3 Metodologia analítica.................................................................................................. 43

3.3.1 A análise gravimétrica da concentração de aerossóis .............................................................4 44

3.3.2 A análise de black carbon equivalente por refletância ........................................................ 45

3.3.3 A análise de compostos iônicos e elementares .................................................................46

3.3.4 A análise da componente carbonácea do aerossol ............................................................50

3.4 A análise multivariada na quantificação de fontes de poluentes..................................................57

3.5 Métodos de análise multivariada............................................................................................5

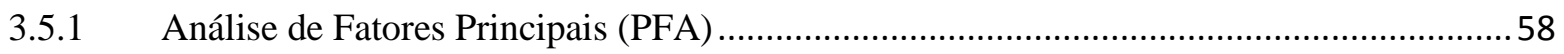

3.5.2 Análise de Fatores Principais Absoluta (APFA) ................................................................62

3.5.3 O modelo de Matriz de Fatoração Positiva (PMF) …………………………………….......63

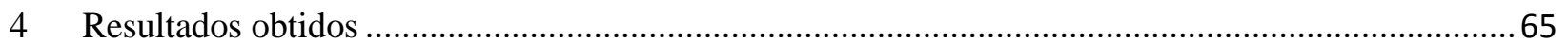

4.1 - Caracterização química do material particulado na RMSP …………………………………...... 65 
4.2 Validação das medidas de material particulado

4.3 A composição elementar e iônica do aerossol em São Paulo ...................................................71

4.4 Comparação entre as medidas feitas por Cromatografia Iônica e XRF .................................... 75

. Tabela 43 - Coeficientes de regressão linear, erro padrão associado (SE ou Standard Error) e coeficientes de correlação $\left(\mathrm{R}^{2}\right)$ obtidos a partir do ajuste entre as medidas por IC e XRF para as estações amostradoras Ibirapuera, IFUSP e Cerqueira César nas frações fina e grossa. Coeficientes de regressão menores que a unidade indicam concentrações medidas por XRF maiores que as medidas por

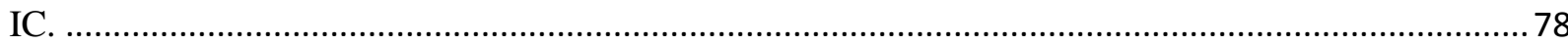

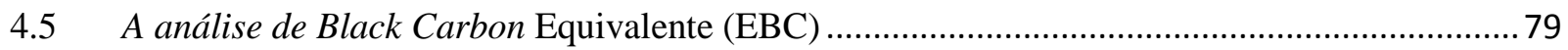

4.6 Conteúdo carbonáceo no aerossol de São Paulo: Carbono orgânico e elementar........................ 82

4.7 Balanço químico de massa das concentrações observadas ........................................................ 86

4.8 A análise dos termogramas na análise térmica diferencial. .....................................................90

4.9 Correlação entre as medidas de Black Carbon Equivalente e Carbono Elementar ....................93

5 Quantificação de fontes na RMSP: resultados da aplicação dos modelos receptores à fração fina do

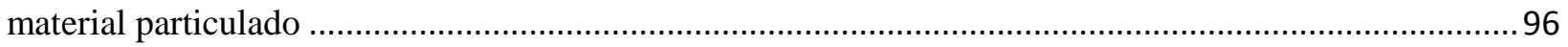

5.1 Resultados da APFA aplicada aos dados da estação Ibirapuera (IBP) ....................................97

5.2 Resultados da APFA aplicada aos dados da estação IFUSP (IFP) ...................................... 100

5.3 Resultados da APFA aplicada aos dados da estação Cerqueira César (FSP) ........................... 105

5.4 Compilação dos resultados obtidos na quantificação de fontes em SP..................................109

5.5 Resultados da APFA aplicada ao conjunto de dados das três estações amostradoras (IFUSP, Cerqueira César e Ibirapuera) ….............................................................................................. 110

5.6 Resultados dos modelos receptores aplicados às frações carbonáceas ................................... 115

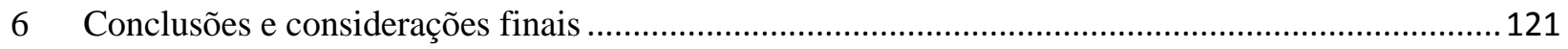

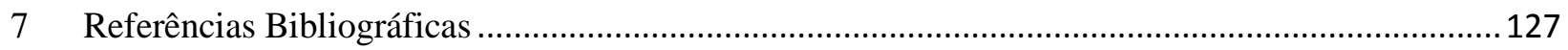

APENDICE A - Tabelas ocultadas na seção 5: Quantificação de fontes na RMSP .................................133 



\section{Introdução}

A questão da poluição atmosférica atinge todos os grandes centros urbanos, em particular as megacidades com população maior do que 10 milhões de habitantes (Zhu et al., 2012). Nestas megacidades, com estrutura complexa da atmosfera, é uma dificuldade crescente a identificação e quantificação de fontes poluidoras (Andrade, 1993a; 1993b), que tem importantes impactos nas políticas de redução de emissões e para minorar o impacto na saúde da população (Braga et al. 2001; Martins et al. 2002; Saldiva et al., 1992; 1994; 1995). Emissões veiculares e industriais destacam-se entre as principais responsáveis pelos altos níveis de poluentes na atmosfera em grandes centros urbanos (Parish e Zhu, 2009). O grande desafio nestas áreas com qualidade do ar comprometida é determinar a contribuição quantitativa das diferentes fontes de emissões para as concentrações de material particulado e de gases. A quantificação detalhada dos diferentes processos de emissão, formação, transporte, deposição e reatividade química desses compostos é um desafio científico. Em particular a componente carbonácea é de difícil quantificação e frequentemente é responsável por mais de $50 \%$ da massa de aerossol fino $\left(\mathrm{PM}_{2.5}\right)$.

\subsection{A atmosfera terrestre}

A atmosfera terrestre é uma camada extremamente fina relativamente ao raio do planeta ${ }^{1}$, estratificada em camadas caracterizadas pelas variações de temperatura e pressão em função da altura. A baixa atmosfera é em geral dividida em troposfera e estratosfera. A maior parte dos poluentes atmosféricos fica contida na troposfera, camada que se estende da superfície terrestre até uma altitude média de 10 a $15 \mathrm{~km}$, onde sofrem transporte e reações químicas.

Em termos de composição, a atmosfera terrestre possui inúmeras substâncias, sendo as majoritárias o nitrogênio diatômico (78\% das moléculas), o oxigênio diatômico (aproximadamente 21\%), o argônio (cerca de $1 \%$ ) e o dióxido de carbono (0,04\%). Outra espécie majoritária é o vapor d'água, extremamente variável nas diversas regiões do planeta e presente de forma predominante na baixa atmosfera. Há ainda compostos que não conseguem se acumular na atmosfera da mesma forma que os componentes principais e se apresentam apenas em

\footnotetext{
${ }^{1}$ Cerca de $99 \%$ da massa que compõe a atmosfera terrestre se encontra até uma altitude máxima de 30 km, o que representa apenas 0,5\% do diâmetro do planeta (Seinfeld and Pandis, 1998).
} 
concentração traço. Os constituintes atmosféricos desempenham papel fundamental no controle da temperatura terrestre, regulando as propriedades termodinâmicas da atmosfera, o clima e a precipitação, e tem papel importante nos ciclos biogeoquímicos, transportando nutrientes e outras substâncias essenciais para o funcionamento e equilíbrio da vida no planeta (Baird e Cann, 2011; Castanho, 1999; Lenzi e Favero, 2011; Monks et al., 2009; Seinfeld e Pandis, 1998).

Além dos diversos compostos gasosos aqui discutidos, a atmosfera também contém partículas sólidas e líquidas (os chamados aerossóis atmosféricos) em suspensão. Os constituintes atmosféricos terrestres mantém entre si complexos processos de interação física e química constante. A sessão a seguir aborda aspectos das partículas de aerossóis atmosféricos, seus processos de emissão e remoção atmosférica, sua composição química e seu importante papel no balanço energético do planeta e na qualidade do ar em centros urbanos.

\subsection{Aerossóis Atmosféricos}

Aerossóis são particulados sólidos ou líquidos em suspensão num gás, com dimensões que variam de alguns nanômetros $(\mathrm{nm})$ a dezenas de micrômetros $(\mu \mathrm{m})$. Aerossóis atmosféricos são classificados, em geral, pelas suas propriedades aerodinâmicas, uma vez que essas propriedades são determinantes nos processos de remoção e transporte atmosférico, bem como penetração e deposição no trato respiratório (CETESB, 2009; Seinfeld and Pandis, 1998). A figura 1-1, extraída de Seinfeld and Pandis (1998), é uma representação clássica dos principais processos que influenciam o tamanho destas partículas.

O material particulado atmosférico divide-se em dois grupos distintos: material particulado grosso (CPM, do inglês Coarse Particulate Matter) com diâmetro aerodinâmico no intervalo de 2.5 a $10 \mu \mathrm{m}$, e material particulado fino ( $\mathrm{PM}_{2.5}$ ou FPM, do inglês Fine Particulate Matter), com diâmetro aerodinâmico inferior a $2.5 \mu \mathrm{m}$. Em geral essas duas modas de tamanho possuem propriedades físicas e químicas diferentes, além de processos de emissão e remoção distintos. Denominam-se ainda, material particulado inalável $\left(\mathrm{PM}_{10}\right)$, o particulado com diâmetro aerodinâmico inferior a $10 \mu \mathrm{m}$ dado pela soma das frações fina e grossa e, finalmente, partículas ultrafinas, aquelas com diâmetros menores que 0,1 $\mu \mathrm{m}$ (Baird e Cann, 2011). 


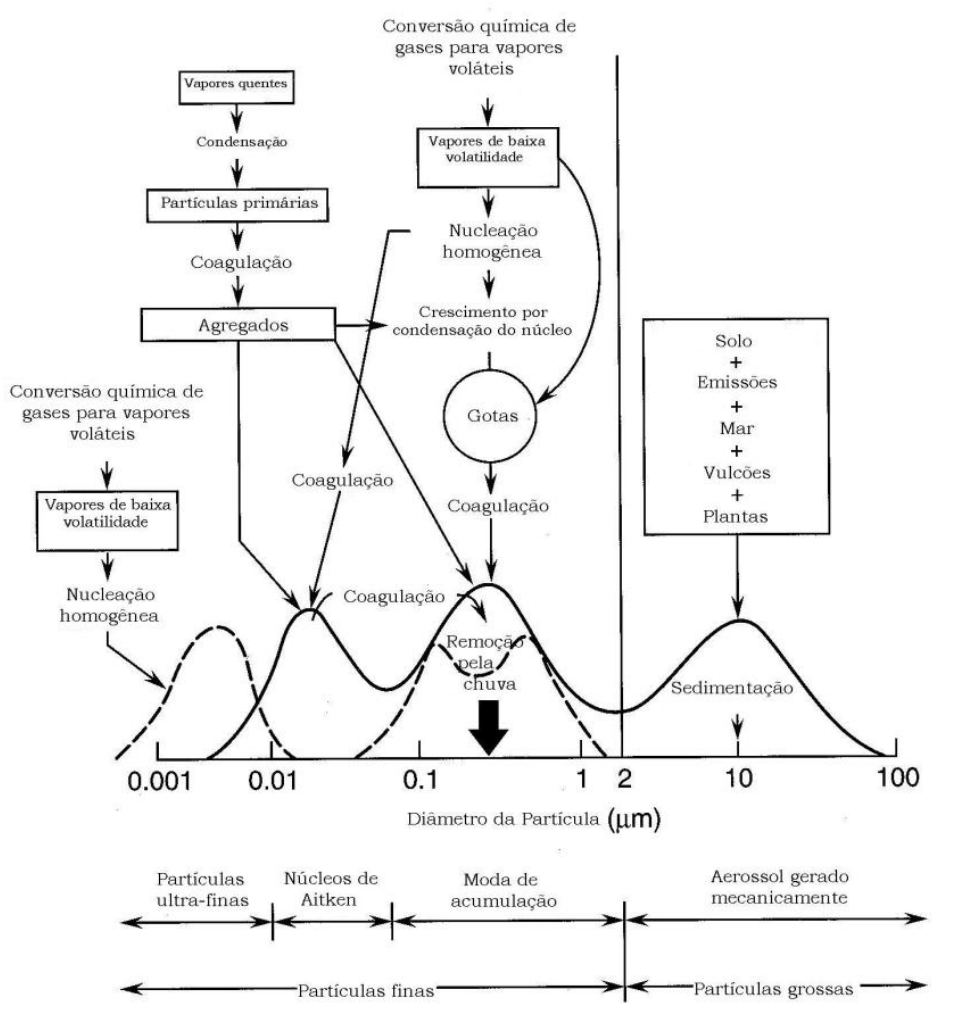

Figura 1-1 - Esquema idealizado da distribuição da área de superfície de aerossóis atmosféricos indicando modas principais, fontes $\mathrm{e}$ mecanismos de formação e remoção das partículas. As 3 modas ilustradas são a moda de nucleação $(10$ - $30 \mathrm{~nm})$, a moda de acumulação $(120-200 \mathrm{~nm})$ e a moda grossa (10 mícrons). A chamada moda de Aitken tem diâmetros da ordem de 50 a 100 nm, interagindo com as modas de nucleação e de acumulação. Fonte: Seinfeld e Pandis (1998).

As partículas na moda de nucleação são formadas em geral por condensação de vapores em processos de combustão e por nucleação de outras espécies atmosféricas. A moda de acumulação origina-se da coagulação de partículas na moda de nucleação e da condensação de vapores em partículas pré-existentes, causando o seu crescimento. Os mecanismos de remoção das partículas na moda de acumulação são menos eficientes do que na moda grossa, o que faz com que as partículas se acumulem neste regime e possuam tempos de residência maiores na atmosfera em relação às modas de nucleação, Aitken e à moda grossa. Em termos de concentração em número de partículas, existe predomínio de partículas nas modas Aitken e de nucleação, que, por outro lado não contribuem significativamente para a massa total do material particulado devido ao seu pequeno tamanho. Em termos de área de superfície de aerossóis, a contribuição majoritária se deve a moda de acumulação. A moda grossa e a moda de acumulação representam a maior parte da concentração em massa do aerossol (Seinfeld e Pandis, 1998). Os particulados atmosféricos originam-se tanto de processos naturais como de processos antrópicos e podem ser classificados como primários (emitidos diretamente da fonte na forma de sólidos e/ou líquidos) ou secundários (formados por processos conversão gás-partícula na atmosfera e/ou 
condensação de compostos gasosos). Uma vez em suspensão na atmosfera experimentam diversas interações e transformações físicas e químicas acarretando mudanças em sua composição, no seu tamanho e na sua estrutura. A concentração, composição química e distribuição de tamanho dessas partículas na atmosfera é bastante variável espacial e temporalmente. A concentração em massa das partículas na atmosfera varia tipicamente na faixa de 1-100 $\mathrm{\mu g} \mathrm{m}^{-3}$ (Monks et al., 2009).

A fração grossa dos aerossóis é geralmente constituída de partículas primárias formadas a partir de processos mecânicos, como desintegração de partículas maiores e suspensão destas pelo vento. Partículas de aerossóis marinhos, poeira do solo e material biogênico são dominantes na fração grossa do aerossol atmosférico. A moda fina, por outro lado, contém majoritariamente partículas primárias geradas em processos de combustão, uso de pneus e freios nos veículos e poeira da fundição de metais; e partículas secundárias formadas na atmosfera a partir de processos de conversão gás-partícula e de coagulação de espécies menores. O tempo de vida dessas partículas na baixa atmosfera é de apenas alguns dias e sua distribuição espacial é extremamente variável (Després et al., 2012; Satheesh e Krishna Moorthy, 2005). O perfil vertical das concentrações também é variável, sendo que a altura da camada de mistura ou de inversão térmica que no meio do dia situa-se de 800 a 2200 metros limita o transporte vertical de partículas.

Partículas de aerossóis atmosféricos podem absorver e espalhar radiação solar, modificando assim o balanço radiativo da atmosfera. Podem também atuar como núcleos de condensação de nuvens (CCN) e como núcleos de gelo (IN), afetando, dessa forma, a microfísica de nuvens, desempenhando importante papel no ciclo hidrológico (Artaxo et al., 1994). Elas também influenciam a química da atmosfera, fornecendo superfícies para reações químicas heterogêneas. É bem estabelecido que altas concentrações de aerossóis em ambientes urbanos, rurais ou indoor, afetam diretamente a saúde humana (Saldiva, 1994; 1995).

A seguir é apresentada uma discussão focada na fração carbonácea do material particulado atmosférico. A terminologia utilizada para definir as diferentes componentes carbonáceas quanto às suas propriedades físico-químicas e as diferentes técnicas de medida também são apresentadas nesta próxima seção. 


\subsubsection{Aerossóis Carbonáceos}

Aerossóis compostos por diversas formas de carbono (aerossóis carbonáceos) consistem principalmente de partículas finas com diâmetro inferior a $2.5 \mu \mathrm{m}$. Esta componente do aerossol tem contribuição de 20 a $80 \%$ da massa total de particulado fino em médias latitudes e contribuição superior a 90\% em regiões tropicais (Monks et al., 2009). O carbono presente nos aerossóis é frequentemente considerado nas formas de carbono orgânico (átomos de carbono que compõem moléculas orgânicas) e carbono elementar (componente fortemente absorvedora de luz, também referida como black carbon ou fuligem) (Gilardoni et al. 2011).

As nomenclaturas utilizadas para definir estas componentes carbonáceas, no entanto, podem conter certas ambiguidades, sobretudo do ponto de vista das características dessas partículas e das técnicas utilizadas para a quantificação das mesmas. É comum observarmos publicações que utilizam a mesma nomenclatura para reportar medidas baseadas em propriedades diferentes. Nesse sentido, Petzold et al. (2013) sugerem uma nomenclatura padronizada, focada tanto nos métodos de medida como nas propriedades físico-químicas dos aerossóis carbonáceos, a fim de estabelecer uma terminologia mais clara. Dentro dessa proposta, que será utilizada nesse trabalho, são definidos os termos:

- Black carbon $(\mathrm{BC})$ é um termo genérico que se refere às substâncias carbonáceas com fortes características absorvedoras de luz. Para uma determinação quantitativa em massa é necessário que se esclareça o método de medida, que em geral é realizado pela absorção ótica de radiação na faixa da luz visível.

- black carbon equivalente (EBC, do inglês equivalent black carbon) define medidas obtidas a partir de técnicas de absorção óptica, e expressas em termos de equivalente em absorção óptica.

- black carbon refratário (rBC, do inglês refractory black carbon) - se refere a componente absorvedora de radiação que é determinado a partir de métodos incandescentes, tais como o SP2 (Soot Particle Instrument da Droplet Measurement Technologies (DMT)).

- Carbono elementar (EC, do inglês elemental carbon) é o termo utilizado em técnicas que determinam especificamente a quantidade de carbono na forma 
elementar que compõe o material carbonáceo, como TOA (análises termoópticas) ou AMS (espectrometria de massa de aerossol), por exemplo. Partículas de EC são em geral refratárias, com alta temperatura de vaporização.

- Carbono orgânico (OC, do inglês organic carbon) é o termo que se refere a todo o carbono presente em compostos orgânicos, ligado a outros elementos como o hidrogênio e oxigênio. Determina-se através de técnicas similares ao EC, e possui baixa temperatura de vaporização.

- Massa orgânica (OM, do inglês organic matter) se refere à massa total de OC somada à massa dos elementos a ele ligados (em geral oxigênio e hidrogênio). Assume-se um fator de 1.4 a 1.6 no calculo do OM a partir do OC.

- Aerossóis orgânicos (OA) é um termo amplo que indica espécies contendo OC ligado a hidrogênio e oxigênio.

- Carbono total (TC, do inglês total carbon) define o carbono total presente em massa no material particulado, ou seja, a soma de OC e EC.

- O termo soot (ou fuligem) é uma descrição qualitativa que se refere ao particulado carbonáceo formado exclusivamente em processos de combustão incompleta.

- Brown Carbon (BrC) se refere à uma fração de OC absorvedora de luz no espectro visível, que não é tão eficientemente absorvedora quanto o Black Carbon.

No que diz respeito às fontes de aerossóis carbonáceos, o EC é um composto emitido primariamente durante processos de queima incompleta de combustíveis fósseis e de biomassa. Todas as fontes de EC emitem também OC para a atmosfera. A emissão primária de OC também inclui fontes naturais como emissões de esporos de plantas, pólens e matéria orgânica do solo, por exemplo. Compostos orgânicos emitidos diretamente na fase de aerossol são referidos como aerossóis orgânicos primários (POA, do inglês Primary Organic Aerosol). Estes podem também ser formados secundariamente na atmosfera através de diferentes processos como conversão gáspartícula, condensação ou adsorção. Esses produtos são referidos como Aerossóis Orgânicos Secundários (SOA, do inglês Secondary Organic Aerosol), sendo que seus principais precursores são compostos orgânicos voláteis (VOC, do inglês Volatile Organic Compounds) biogênicos. A 
contribuição antropogênica para a formação de partículas de SOA é pequena em escala global, no entanto pode ser significativa em regiões urbanas poluídas (Kanakidou, 2005).

Quanto às propriedades ópticas, BC é a espécie mais eficiente em termos de absorção de luz na faixa do visível. Dois outros tipos de aerossóis atmosféricos absorvem luz visível: poeira do solo e brown carbon $(\mathrm{BrC})$. A fração de $\mathrm{OC}$ absorvedora de luz no espectro visível $(\mathrm{BrC})$ consiste de uma complexa mistura de compostos orgânicos sem uma definição analítica formal. A absorção de luz pelo $\mathrm{BrC}$ é fortemente dependente do comprimento de onda com banda de absorção mais intensa no azul (Bond et al., 2013). As partículas de BrC, similarmente ao BC, predominam na fração fina.

A figura 1-2 ilustra a variedade de processos de combustão naturais e antropogênicos responsáveis pela emissão de $\mathrm{BC}$ bem como as diversas interações destes aerossóis com o sistema terrestre. Partículas de BC são emitidas conjuntamente a uma variedade de aerossóis (em particular com OC) e de precursores na fase gasosa de modo que, após a emissão, estas espécies se misturam na atmosfera. Essa interação com os diferentes componentes do aerossol influenciam fortemente as propriedades ópticas do BC e seu tempo de vida na atmosfera (Bond et al., 2013). 


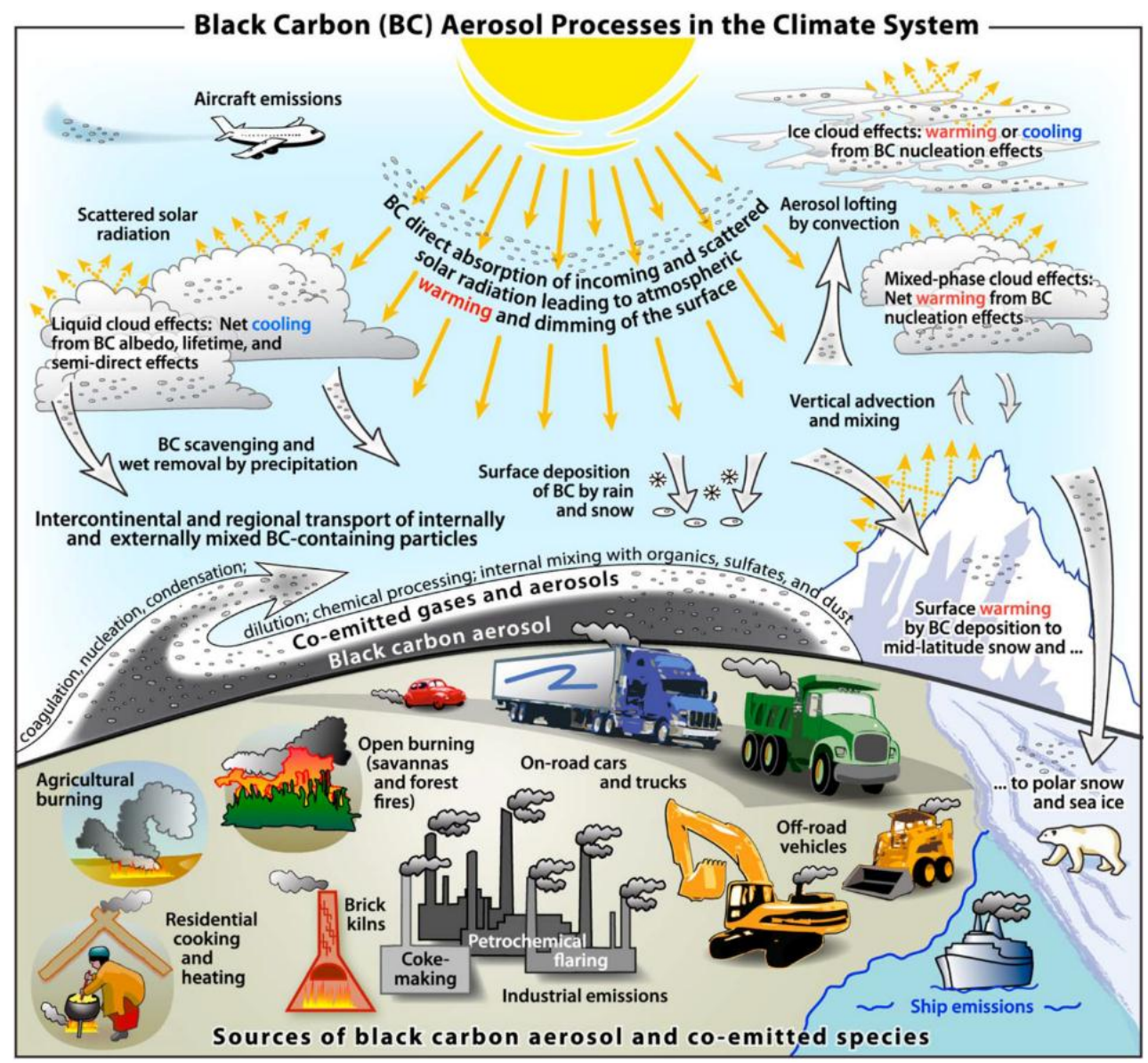

Figura 1-2 - Visão geral das fontes de emissão primária de black carbon e processos que controlam a sua distribuição na atmosfera. Figura extraída de Bond et al., (2013).

\subsection{A poluição do ar em ambientes urbanos}

Uma condição de poluição do ar pode ser definida como uma situação em que substâncias resultantes de atividades antrópicas estejam presentes na atmosfera em concentrações acima dos níveis ambientais normais, suficientemente altas a ponto de produzir efeitos negativos mensuráveis em seres humanos, plantas, animais e materiais (Seinfeld e Pandis, 1998).

Até hoje, mais de 3000 poluentes de origem antrópica foram identificados na atmosfera. Apenas os processos de combustão, como em motores veiculares, podem ser responsáveis pela emissão de cerca de 500 compostos diferentes para a atmosfera. No entanto, apenas uma fração destes compostos tem o seu impacto investigado; e um número ainda menor têm suas concentrações ambientais determinadas (Austin et al., 2002). 


\subsubsection{Principais Poluentes Atmosféricos: Os Padrões de Qualidade do Ar}

O nível de poluição atmosférica é determinado pela quantificação das concentrações de poluentes atmosféricos presentes no ar. Considera-se poluente qualquer substância presente no ar e que possa, pela sua concentração, possa ser impróprio, nocivo ou ofensivo à saúde, causando inconveniente ao bem estar público, danos aos materiais, à fauna e à flora (CETESB, 2013).

Poluentes podem ser lançados na atmosfera por emissões diretas (poluentes primários) ou formados através de reações químicas entre poluentes primários e/ou constituintes naturais, gerando os chamados poluentes secundários. A qualidade do ar depende das concentrações destes poluentes, mas também das condições meteorológicas favoráveis ou não à dispersão dos mesmos. Comumente, um grupo de poluentes é escolhido como indicador da qualidade do ar em áreas urbanas, devido aos seus efeitos adversos à saúde humana e ao meio ambiente. Esses indicadores são os gases dióxido de enxofre $\left(\mathrm{SO}_{2}\right)$, monóxido de carbono (CO), óxidos de nitrogênio $\left(\mathrm{NO}_{\mathrm{x}}=\mathrm{NO}+\mathrm{NO}_{2}\right)$ e o ozônio $\left(\mathrm{O}_{3}\right)$, além do material particulado (MP).

Quanto aos gases, $\mathrm{SO}_{2}, \mathrm{CO}$ e $\mathrm{NO}_{\mathrm{x}}$ originam-se basicamente de processos de combustão. Moléculas de $\mathrm{CO}$ resultam da queima incompleta de combustíveis fósseis, enquanto o $\mathrm{SO}_{2}$ é associado à queima de enxofre presente nos combustíveis. Os óxidos de nitrogênio são formados principalmente a partir da oxidação de moléculas de nitrogênio a altas temperaturas, sendo a maior parte emitida na forma de óxido nítrico (NO), subsequentemente oxidado na atmosfera formando $\mathrm{NO}_{2}$ que, na presença de luz do sol, reage com hidrocarbonetos e oxigênio formando oxidantes fotoquímicos ${ }^{2}$, dentre os quais se destaca o ozônio.

Em relação ao material particulado (MP), como discutido nas seções anteriores, se refere a partículas sólidas ou líquidas suspensas na atmosfera, na forma de poeira, neblina, fumaça, fuligem, etc. Tratando-se de um parâmetro de qualidade do ar, são definidos os seguintes termos para o MP: partículas inaláveis finas $\left(\mathrm{MP}_{2.5}\right)$, com tamanho menor que $2.5 \mu \mathrm{m}$; partículas

\footnotetext{
${ }^{2}$ A denominação Oxidantes Fotoquímicos se refere ao conjunto de poluentes secundários formados pelas reações entre óxidos de nitrogênio e VOCs, na presença de luz solar. O principal produto desta reação é o ozônio, por isso o mesmo é utilizado como parâmetro indicador da presença de oxidantes fotoquímicos na atmosfera (CETESB, 2013).
} 
inaláveis $\left(\mathrm{MP}_{10}\right)$, com tamanho menor que $10 \mu \mathrm{m}$; e partículas totais em suspensão (PTS), com tamanho de até 50 a $100 \mu \mathrm{m}$.

Observa-se, sobretudo em áreas urbanas como a RMSP, que os poluentes principais estão direta ou indiretamente associados a emissões veiculares e, portanto, medidas reguladoras aplicadas a este setor podem implicar em reduções significativas nas suas concentrações e em seus efeitos. As emissões de $\mathrm{SO}_{2}$, por exemplo, podem ser reduzidas com o uso de combustíveis com baixo conteúdo de enxofre, como o gás natural veicular (GNV). Emissões de $\mathrm{NO}_{\mathrm{x}}$ e $\mathrm{CO}$ podem ser reduzidas pela otimização dos processos de combustão e uso de conversores catalíticos no escapamento dos veículos (Carvalho, 2015; Fenger, 1999).

Muitos efeitos adversos à saúde podem ser atribuídos aos diferentes níveis de exposição da população a esses poluentes atmosféricos. Alguns dos efeitos gerais dessas substâncias sobre a saúde humana, sobretudo em ambientes urbanos, e uma breve discussão sobre os padrões de qualidade do ar serão apresentados na seção 1.4. A seguir, serão discutidos aspectos relevantes sobre a RMSP e suas emissões de poluentes atmosféricos.

\subsubsection{São Paulo - Megacidade de impacto global}

Megacidades são grandes conglomerados urbanos com mais de 10 milhões de habitantes, notáveis por seu tamanho e concentração de atividades econômicas (Zhu et al., 2012). Em 1990, apenas 10 cidades possuíam tal contingente populacional e as megacidades constituíam aproximadamente 150 milhões de pessoas (menos de 7\% da população urbana global). Em 2015, o número de megacidades quase triplicou: são 28 aglomerações urbanas com uma população superior a 450 milhões de pessoas (12\% da população urbana em todo o mundo). No ano de 2007, pela primeira vez na história a população urbana mundial excedeu a população rural. Em 2015, 54\% da população mundial vivem em áreas urbanas (ONU, 2014). A figura 1-3 mostra uma projeção das principais megacidades em todo o mundo.

A poluição do ar representa uma significativa ameaça à saúde humana e ao meio ambiente tanto em países desenvolvidos como em países em desenvolvimento, configurando um dos principais problemas em áreas urbanas, exercendo forte impacto em escalas regional e global. A rápida urbanização tem como resultado aceleração dos níveis de emissão de poluentes 
atmosféricos devido ao transporte, à produção de energia e às atividades industriais. Consequentemente, as emissões de gases e partículas em megacidades estão tornando-se gradativamente foco de interesse global (Gurjar et al., 2008).

\section{Megacidades no mundo: 19 em 2007, 27 em 2025.}

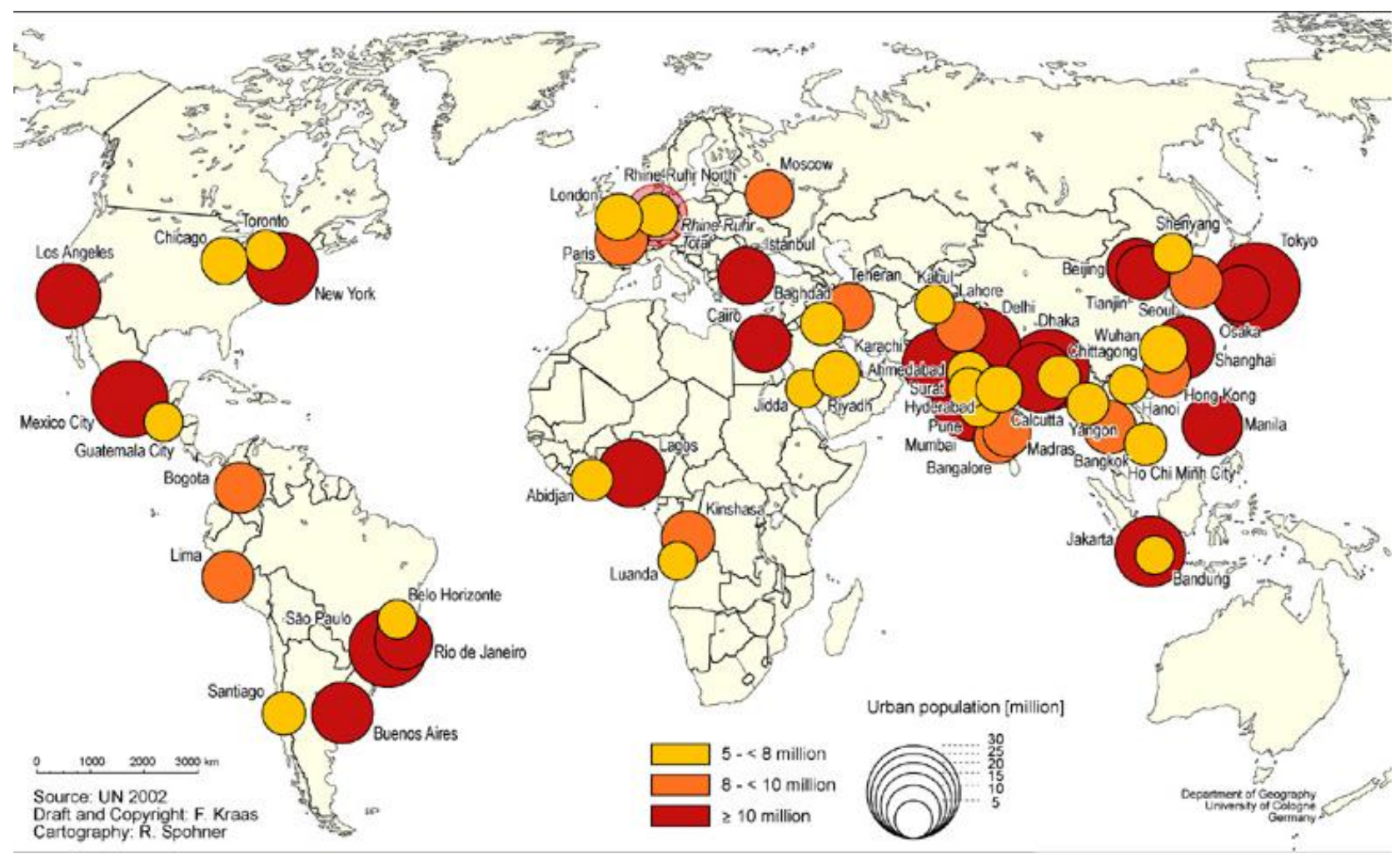

Figura 1-3 - Distribuição geográfica das megacidades e cidades com 5 a 8 milhões de habitantes. Fonte: http://www.megacities.uni-koeln.de/documentation/megacity/map/MC-2015-PGM.jpg

De acordo com dados do IBGE, cerca de $85 \%$ da população brasileira residem em áreas urbanas (IBGE, 2010). A maior parte desta população é afetada pela poluição do ar, principalmente em decorrência de emissões do setor de transportes. Apesar de características especificas em cada cidade, os tipos de combustível usados no Brasil são tipicamente etanol (95\% etanol; 5\% água), gasolina misturada a etanol (75\% gasolina; 25\% etanol) e gás natural veicular (GNV), para veículos leves; além de diesel e, em menor proporção, biodiesel, para veículos pesados (Andrade et al., 2012). 
A Região Metropolitana de São Paulo ou RMSP (figura 1-4) já é classificada como a quinta maior megacidade do mundo, com cerca 20 milhões de habitantes, o que representa um décimo da população brasileira (IBGE, 2010). Quanto à sua urbanização, a cidade de São Paulo experimentou, especialmente no final da década de 1970, acentuada descentralização das moradias que irradiaram para vários pontos de cidades que vieram a compor a RMSP, originando um padrão periférico de ocupação do solo urbano (Kowarick e Rezende, 2000). Hoje é constituída por 39 municípios, distribuídos em 5 sub-regiões, ocupando uma área superior a 8 mil $\mathrm{km}^{2}$, pouco mais de $3 \%$ do território do estado de SP, sendo que mancha urbana contínua, que já ultrapassa os 2 mil km², abrangendo cerca de 30 municípios (EMPLASA, 2011).

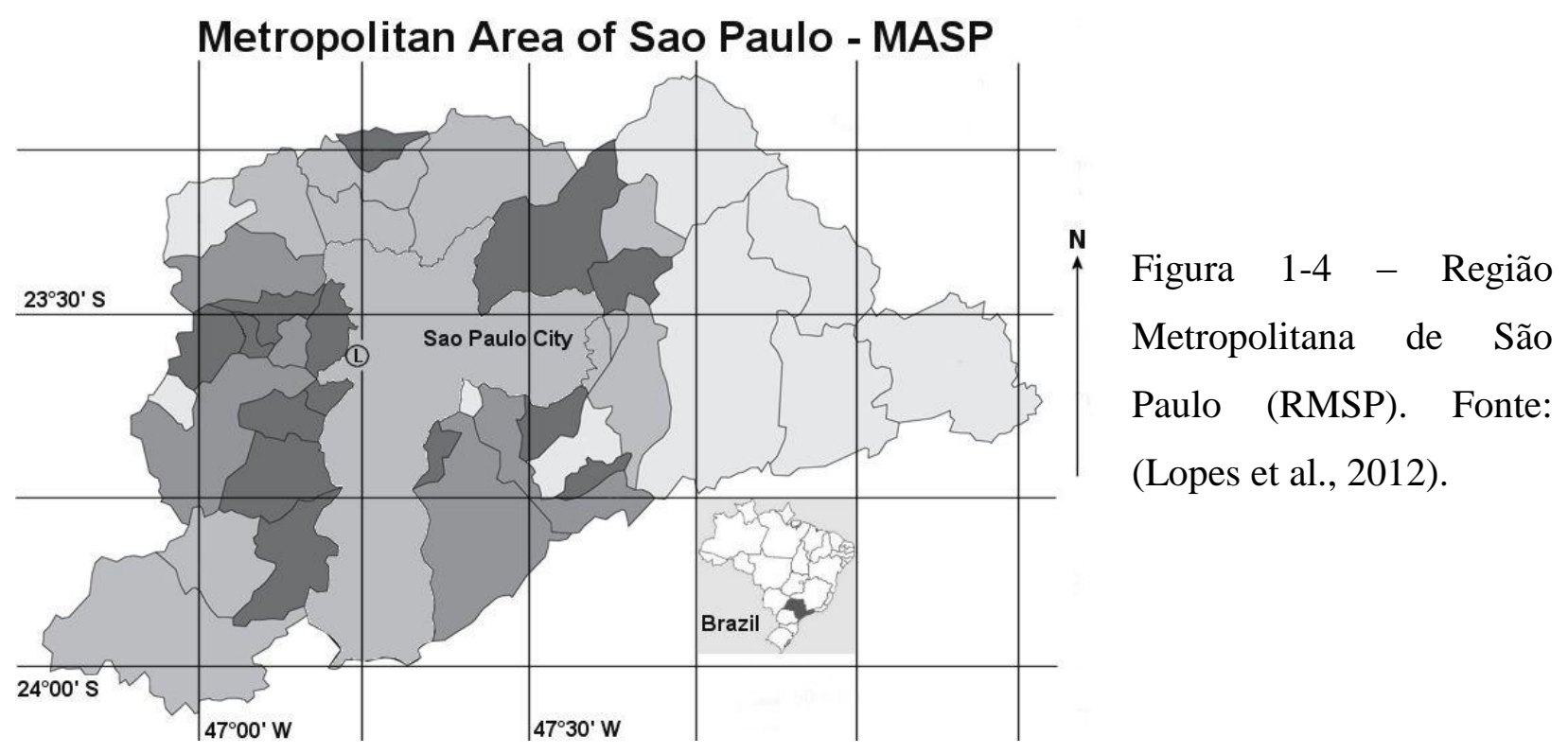

Quanto aos seus aspectos climáticos, a RMSP é caracterizada por um inverno seco e um verão chuvoso. A estação seca (inverno) é caracterizada pela frequente ocorrência de inversões térmicas a baixa altitude e grande estabilidade atmosférica, o que é desfavorável à dispersão de poluentes. Quanto aos aspectos geográficos da RMSP, destaca-se a sua proximidade do Oceano Atlântico e das Serras do Mar e da Cantareira. A climatologia local é fortemente influenciada pela ocorrência dos fenômenos de brisa marinha e brisa terrestre (Andrade et al., 1994; Castanho, 1999). Na RMSP, a frota veicular supera 7 milhões de veículos, uma das maiores frotas por habitante do mundo. Na tabela 1-1 são apresentadas informações sobre a frota circulante no estado de São Paulo em 2013. 


\begin{tabular}{|c|c|c|c|c|c|c|}
\hline \multicolumn{2}{|c|}{ Categoiia } & Combustível & $\begin{array}{l}\text { Idade } \\
\text { média }^{a}\end{array}$ & $\begin{array}{l}\text { Estado de } \\
\text { SP }\end{array}$ & RMSP & $\begin{array}{l}\text { Município de } \\
\text { SP }\end{array}$ \\
\hline \multirow{3}{*}{\multicolumn{2}{|c|}{ Automóveis leves }} & Gasolina C & \multirow{3}{*}{9} & 3.902 .442 & 2.153 .300 & 1.379 .789 \\
\hline & & Etanol Hidratado & & 363.966 & 154.896 & 102.697 \\
\hline & & Flex & & 5.550 .113 & 2.805 .086 & 1.773 .793 \\
\hline \multirow{4}{*}{\multicolumn{2}{|c|}{ Comerciais leves }} & Gasolina C & \multirow{4}{*}{7} & 674.735 & 392.355 & 269.817 \\
\hline & & Etanol Hidratado & & 36.295 & 14.224 & 9.331 \\
\hline & & Flex & & 794.105 & 343.380 & 215.392 \\
\hline & & Diesel & & 343.766 & 151.622 & 94.301 \\
\hline \multirow{5}{*}{ Caminhões } & Semileves & \multirow{5}{*}{ Diesel } & \multirow{5}{*}{11} & 42.355 & 16.545 & 7.672 \\
\hline & Leves & & & 118.449 & 46.172 & 21.401 \\
\hline & Médios & & & 73.475 & 29.021 & 13.468 \\
\hline & Semipesados & & & 100.998 & 39.999 & 18.536 \\
\hline & Pesados & & & 100.089 & 39.616 & 18.356 \\
\hline \multirow{3}{*}{ Ônibus } & Ulbanos & \multirow{3}{*}{ Diesel } & \multirow{3}{*}{11} & 63.442 & 33.638 & 20.067 \\
\hline & Micro-ônibus & & & 28.666 & 7.541 & 4.465 \\
\hline & Rodoviánios & & & 13.855 & 14.791 & 8.949 \\
\hline \multirow{2}{*}{\multicolumn{2}{|c|}{ Motocicletas }} & Gasolina C & \multirow{2}{*}{7} & 2.215 .367 & 795.385 & 450.298 \\
\hline & & Flex & & 386.266 & 85.964 & 44.105 \\
\hline \multicolumn{3}{|c|}{ Total } & 8 & 14.808 .384 & 7.123 .534 & 4.452 .436 \\
\hline
\end{tabular}

Tabela 1-1 - Estimativa da frota circulante em 2013 no estado, na região metropolitana e no município de São Paulo por tipo de veículo/combustível e estimativa da idade média da frota no estado para o mesmo ano. Fonte: CETESB (2013).

Observa-se expressiva participação de automóveis leves na composição da frota, representado $66 \%$ do total. A idade média da frota no estado de São Paulo é de pouco mais que 8 anos, contudo em 2013 ainda existiam cerca de 5 milhões de veículos com mais de 10 anos de uso, com fatores de emissão de poluentes mais altos do que veículos mais novos (CETESB, 2013). Nos últimos anos verificou-se expressivo aumento no número de automóveis e comerciais leves e motocicletas flex fuel. Estima-se que 55\% do combustível usado hoje na RMSP seja etanol. Esse aspecto particular e relevante tem alterado significativamente a composição do material particulado na RMSP a tornando um laboratório único para estudos de aerossóis provenientes do uso de biocombustíveis (Backman et al., 2012; Brito et al., 2013, Nogueira et al. 2014). 
Dentre as opções de transporte coletivo na RSMP, o Metrô (com apenas $61.3 \mathrm{~km}$ de extensão) atende a uma demanda média de 3,6 milhões passageiros por dia; seguido do transporte ferroviário metropolitano (com $122.7 \mathrm{~km}$ de extensão ao longo da região metropolitana) de responsabilidade da Companhia Paulista de Trens Metropolitanos (CPTM), que transporta 2,1 milhões de passageiros por dia. O transporte coletivo sobre pneus (ônibus movidos principalmente a diesel) inclui os serviços municipal, metropolitano e de fretamento, e movimenta 8,2 milhões de passageiros diariamente (EMPLASA, 2011). A RMSP é também a mais industrializada em toda a América do Sul, concentra importantes complexos comerciais e financeiros e sofre de problemas crônicos de poluição atmosférica, registrados desde meados da década de 1980 (CETESB, 2009; Orsini et al., 1986).

\subsection{Efeitos da poluição do ar à saúde humana}

A degradação da qualidade do ar, especialmente em ambientes urbanos, tem sido associada ao agravamento de doenças respiratórias, cardiovasculares e neurológicas, principalmente em crianças e idosos. Estudos indicam também correlação entre a exposição a alguns poluentes e a ocorrência de diferentes tipos de câncer, além de mudanças na expectativa de vida da população (Santana et al., 2012; Silva et al., 2012). Estudos recentes (Ribeiro, 2011) observaram associação positiva e consistente entre a exposição ao material particulado inalável e a incidência de câncer de pulmão na cidade de SP.

A partir da primeira metade do século XX, episódios de poluição do ar excessiva em cidades na Europa e nos Estados Unidos foram associados a fortes efeitos na saúde, com aumento da mortalidade. Destacam-se episódios ocorridos em 1930, no vale de Meuse, Bélgica, em 1943 em Los Angeles, e em 1948, em Donora, Pennsylvania entre outros. Nestes episódios observou-se forte emissão de poluentes associados a situações de condições meteorológicas desfavoráveis à dispersão de poluentes em que foram registrados aumento no número de doenças respiratórias e excesso de mortes. Contudo, durante o inverno de 1952, em Londres, ocorreu o mais grave episódio de smog fotoquímico ${ }^{3}$, em um episódio de inversão térmica ${ }^{4}$ que dificultou a

\footnotetext{
${ }^{3} \mathrm{O}$ fenômeno chamado de smog fotoquímico se refere a episódios de poluição do ar em áreas urbanas durante os quais são produzidos elevados níveis de ozônio, $\mathrm{O}_{3}$ - um constituinte indesejável se encontrado a baixas altitudes no ar que respiramos - como resultado das reações entre poluentes induzidas pela luz. A palavra smog é uma
} 
dispersão de poluentes. Na ocasião, foi observado grandes concentrações de material particulado e enxofre, de até nove vezes maiores do que a média, que permaneceu estacionada sobre a cidade durante aproximadamente três dias. Foi registrado um aumento de quatro mil mortes em relação à média de óbitos em períodos semelhantes (Baird e Cann, 2011).

Em virtude desses episódios, esforços para entender e mitigar os efeitos da poluição do ar na saúde e bem-estar humano foram intensificados. Durante as décadas de 70 e 80, a relação entre doenças cardiopulmonares e altas concentrações de material particulado foram amplamente aceitas. Em meados dos anos 90 pesquisas epidemiológicas reportaram efeitos adversos à saúde humana mesmo em baixas concentrações de material particulado ambiental (Pope e Dockery, 2006).

A Organização Mundial da Saúde (OMS) estima que em 2012 cerca de 7 milhões de pessoas morreram em decorrência da poluição do ar em todo o planeta. Nas Américas, foram 96 mil mortes nos países desenvolvidos e 131 mil nos demais (WHO, 2014). Em São Paulo, estimase um excesso de 7 mil mortes prematuras ao ano na região metropolitana decorrentes do impacto da poluição do ar na saúde humana. A poluição do ar é responsável uma redução de 1,5 anos de vida da população, com um custo financeiro podendo chegar a mais de um bilhão de dólares por ano (Saldiva e Vormittag, 2013).

O impacto das partículas de aerossóis atmosféricos sobre populações urbanas se deve principalmente aos seus efeitos adversos na saúde, sobretudo nos sistemas respiratório e cardiovascular (Figura 1-5). Ao serem inaladas, as partículas são depositadas em diferentes regiões do trato respiratório (Figura 1-6). A profundidade dessa deposição é maior quanto menor o diâmetro das partículas. Uma fração das partículas grossas é retida já nas narinas, de onde são eliminadas por espirros ou pelo muco. Partículas um pouco menores se depositam na região extratorácica, podendo, inclusive, ser depositadas ao longo da traqueia e dos brônquios. O aparelho mucociliar, a fagocitose e a tosse são mecanismos responsáveis pela remoção das

combinação de smoke (fumaça) e fog (névoa). O processo de formação de smog envolve centenas de diferentes reações, envolvendo inúmeras substâncias químicas, ocorrendo simultaneamente (Baird e Cann, 2011).

4 A inversão térmica é um fenômeno atmosférico comum, sobretudo em áreas cercadas por serras ou montanhas. Ocorre quando o ar frio (mais denso) é impedido de circular por uma camada de ar quente (menos denso). A camada de ar frio fica próxima à superfície terrestre, região com maior concentração de poluentes, prejudicando a dispersão destes. Este fenômeno se intensifica nos períodos de inverno quando o ar próximo à superfície sofre maior perda de calor e se torna mais frio que as camadas superiores. 
partículas que atingem este nível do trato respiratório. Entretanto, partículas finas e ultrafinas podem atingir a região dos alvéolos e a corrente sanguínea. Aerossóis orgânicos, especificamente, representam grande fator de ameaça à saúde humana, pois certas frações, especialmente aquelas contendo hidrocarbonetos policíclicos aromáticos ( $\mathrm{PAH}$, do inglês polycyclic aromatic hydrocarbons), podem ser cancerígenas e mutagênicas (Andrade et al., 1994; Castanho, 2005; CETESB, 2009; Seinfeld e Pandis, 1998).

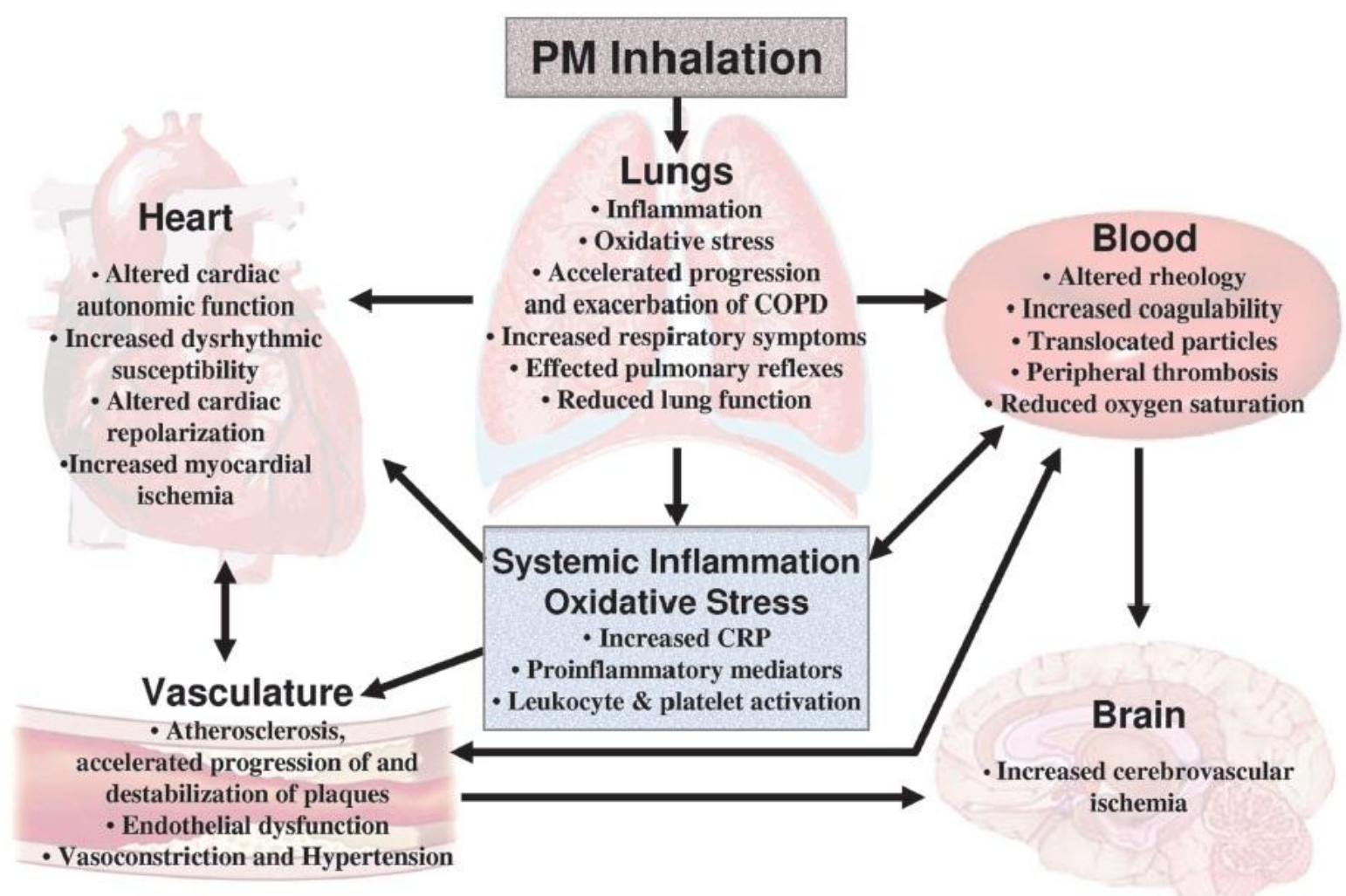

Figura 1-5 Efeitos da inalação de poluentes atmosféricos na saúde humana. Fonte: Pope e Dockery (2006).

De acordo com estimativas do ano de 2009, cada habitante de São Paulo gastava em média 2 horas e 47 minutos diariamente para se locomover pela cidade (IBOPE, 2009). A redução da velocidade de tráfego e aumento dos congestionamentos impõe maiores níveis de exposição à população que permanece mais tempo em corredores de tráfego, onde os níveis de poluição são mais elevados. Do ponto de vista econômico, um aumento no tempo gasto no trânsito envolve diversos custos adicionais com combustível e manutenção dos veículos, aumento no número de internações hospitalares, queda de produtividade, etc. (Silva et al., 2012). 

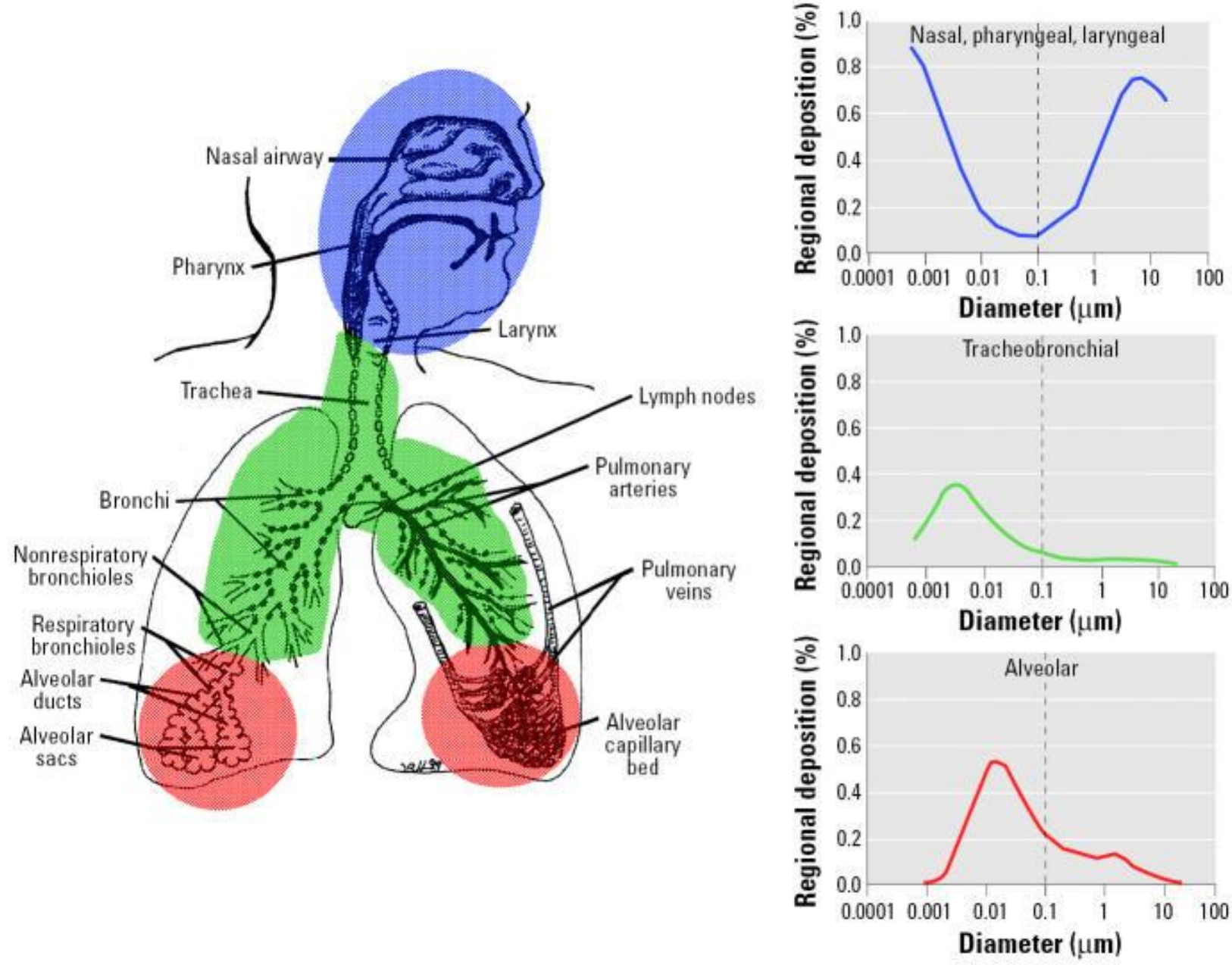

Figura 1-6 - A deposição de partículas no trato respiratório humano. Adaptada de Oberdoester (2005).

Os grupos mais atingidos pelo aumento da poluição do ar são, principalmente, idosos, crianças, gestantes e portadores de doenças respiratórias e cardíacas crônicas. No entanto, a população de regiões mais periféricas da cidade é a que está submetida a níveis maiores de exposição. O maior tempo de permanência no tráfego, dentro de transportes públicos, amplia a exposição dessas pessoas aos diversos poluentes atmosféricos. Além disso, a alta demanda pelo transporte público impõe os usuários a longos períodos de espera em pontos de ônibus, locais de alta concentração de poluentes em virtude da maior proximidade das fontes (Veronez et al., 2012). É indiscutível que a questão da mobilidade urbana e a poluição atmosférica estejam atreladas, de modo que políticas afirmativas de melhoria no transporte público tenham impacto direto na qualidade do ar em regiões urbanas como São Paulo. 


\subsubsection{Os Padrões de Qualidade do Ar}

De acordo com a Organização Mundial da Saúde (WHO), os padrões de qualidade do ar (PQAR) devem ser considerados como o nível máximo de concentração permitido para um poluente atmosférico por uma autoridade regulatória. Ainda segundo a WHO cabe aos governos estabelecer seus próprios PQAR em função do nível de desenvolvimento do seu país, da viabilidade tecnológica, dos riscos existentes à saúde, de considerações econômicas e de outros fatores sociais e políticos (Santana et al., 2012). A tabela 1-2 apresenta os PQAR estabelecidos pela legislação federal americana e atualmente em vigor.

\begin{tabular}{|c|c|c|c|c|}
\hline POLUENTE & $\begin{array}{l}\text { PRIMÁRIO E/OU } \\
\text { SECUNDÁRIO(") }\end{array}$ & $\begin{array}{c}\text { TEMPO DE } \\
\text { AMOSTRAGEM }\end{array}$ & CONCENTRAÇÃOO & OBSERVAÇÃOO \\
\hline \multirow{2}{*}{ CO (2011) } & \multirow{2}{*}{ Primário } & $8 \mathrm{~h}$ & $9 \mathrm{ppm}$ & \multirow{2}{*}{$\begin{array}{l}\text { Não deve ser excedido mais que uma vez } \\
\text { ao ano }\end{array}$} \\
\hline & & $1 \mathrm{~h}$ & $35 \mathrm{ppm}$ & \\
\hline $\begin{array}{l}\text { CHUMBO } \\
\text { (2008) }\end{array}$ & $\begin{array}{l}\text { Primário e } \\
\text { secundário }\end{array}$ & $\begin{array}{l}\text { Média móvel } \\
\text { trimestral }\end{array}$ & $0,15 \mu \mathrm{g} / \mathrm{m}^{3}$ & Não deve ser ultrapassado \\
\hline \multirow[b]{2}{*}{$\mathrm{NO}_{2}$ (2010) } & Primário & $1 \mathrm{~h}$ & $100 \mathrm{ppb}$ & Percentil 98 sobre médias de 3 anos \\
\hline & $\begin{array}{l}\text { Primário e } \\
\text { secundário }\end{array}$ & Anual & $53 \mathrm{ppb}$ & Média anual \\
\hline $\begin{array}{l}\mathrm{O}_{3} \text { (OZÔNIO } \\
-2 \text { 2008) }\end{array}$ & $\begin{array}{l}\text { Primário e } \\
\text { secundário }\end{array}$ & $8 \mathrm{~h}$ & $0,075 \mathrm{ppm}$ & $\begin{array}{l}\text { Quarta maior máxima média diária de } \\
8 \text { horas anual sobre médias de } 3 \text { anos }\end{array}$ \\
\hline \multirow{2}{*}{$\begin{array}{c}\mathrm{MP}_{2,5} \\
(2006)\end{array}$} & \multirow{2}{*}{$\begin{array}{l}\text { Primário e } \\
\text { secundário }\end{array}$} & Anual & $15 \mu \mathrm{g} / \mathrm{m}^{3}$ & Média anual sobre médias de 3 anos \\
\hline & & $24 \mathrm{~h}$ & 35 & Percentil 98 sobre médias de 3 anos \\
\hline $\mathrm{MP}_{10}(\mathbf{2 0 0 6 )}$ & $\begin{array}{l}\text { Primário e } \\
\text { secundário }\end{array}$ & $24 \mathrm{~h}$ & $150 \mu \mathrm{g} / \mathrm{m}^{3}$ & $\begin{array}{l}\text { Não deve ser excedido mais de uma vez } \\
\text { por ano sobre médias de } 3 \text { anos }\end{array}$ \\
\hline \multirow{2}{*}{$\mathrm{SO}_{2}(2010)$} & Primário & $1 \mathrm{~h}$ & $75 \mathrm{ppb}$ & $\begin{array}{l}\text { Percentil } 99 \text { das máximas de } 1 \mathrm{~h} \text { diária(s), } \\
\text { média de } 3 \text { anos }\end{array}$ \\
\hline & Secundário & $3 \mathrm{~h}$ & $0,5 \mathrm{ppm}$ & $\begin{array}{l}\text { Não deve ser excedido mais de uma vez } \\
\text { por ano }\end{array}$ \\
\hline
\end{tabular}

${ }^{*}$ *) Os padrões primários devem permitir uma margem adequada de segurança para proteção da saúde pública. Os padrões secundários devem ser adequados à proteção do bem-estar público, compreendendo, entre estes, os efeitos sobre a vegetação, colheitas, solos, águas, fauna, materiais sintéticos e a visibilidade.

Tabela 1-2 - Padrões nacionais de qualidade do ar atualmente em vigor nos EUA. Fonte: (Santana et al., 2012).

No Brasil, segundo o Conselho Nacional do Meio Ambiente (CONAMA), em sua Resolução 03/1990 (Art. 1), "são padrões de qualidade do ar as concentrações de poluentes atmosféricos que, ultrapassadas, poderão afetar a saúde, a segurança e o bem-estar da população, 
bem como ocasionar danos à fauna e à flora, aos materiais e ao meio ambiente em geral". Considera-se um poluente atmosférico "qualquer forma de matéria ou energia com intensidade e em quantidade, concentração, tempo ou características em desacordo com os níveis estabelecidos, e que tornem ou possam tornar o ar: (1) impróprio, nocivo ou ofensivo à saúde; (2) inconvenientemente ao bem-estar público; (3) danoso aos materiais, à fauna e à flora; ou (4) prejudicial à segurança, ao uso e gozo da propriedade e às atividades normais da comunidade”.

Esta resolução do CONAMA (Art. $3^{\circ}$ ) define os padrões nacionais de qualidade do ar PNQA para Partículas Totais em Suspensão (PTS), fumaça, material particulado inalável (MP 10$)$, monóxido de carbono $(\mathrm{CO})$, dióxido de nitrogênio $\left(\mathrm{NO}_{2}\right)$, dióxido de enxofre $\left(\mathrm{SO}_{2}\right)$ e ozônio $\left(\mathrm{O}_{3}\right)$. No caso do particulado fino $\left(\mathrm{PM}_{2.5}\right)$ a legislação brasileira ainda não possui PQAR, embora nos Estados Unidos, por exemplo, estes tenham sido estabelecidos em 1997. A Tabela 1-3 sumariza os valores vigentes na atual legislação brasileira.

No estado São Paulo, a legislação estadual também estabelece padrões de qualidade do ar, mas abrange um número menor de parâmetros. Os parâmetros fumaça, partículas inaláveis e dióxido de nitrogênio não têm padrões e critérios estabelecidos pela legislação estadual em São Paulo. Os parâmetros comuns à legislação estadual e federal têm os mesmos padrões e critérios para episódios agudos de poluição do ar, com exceção dos critérios de episódio para ozônio. Neste caso a legislação estadual é mais rigorosa para o nível de atenção de $200 \mu \mathrm{g} / \mathrm{m}^{3}$ (CETESB, 2012).

A CETESB mantém desde a década de 70, redes de monitoramento da qualidade do ar e de parâmetros meteorológicos em diversos municípios do estado de São Paulo. Os dados são divulgados em termos de uma classificação da qualidade do ar em função dos níveis monitorados, juntamente com eventuais informações de prevenção de riscos à saúde. Na RMSP, os principais parâmetros com frequentes ultrapassagens dos padrões de qualidade do ar são ozônio e material particulado. Com o objetivo de reduzir e controlar a contaminação atmosférica por fontes móveis, o CONAMA, em, criou os programas de controle da poluição do ar por veículos e por motocicletas, PROCONVE e o PROMOT, respectivamente. Tais programas consistem na fixação de prazos e limites máximos de emissão, estabelecendo exigências tecnológicas para veículos automotores nacionais e importados. No entanto, a relativa redução 
nas emissões veiculares em virtude desses programas, tende a ser contrabalanceada pelo uso intensivo de veículos para o transporte individual e pelo aumento da frota nos últimos anos (Carvalho, 2015; CETESB, 2012).

\begin{tabular}{|c|c|c|c|}
\hline \multirow{2}{*}{ POLUENTE } & \multirow{2}{*}{ TEMPO MÉDIO DE AMOSTRAGEM } & \multicolumn{2}{|c|}{ CONCENTRAÇÃO (VIOLAÇÕES ACEITAS POR ANO) } \\
\hline & & PADRÃO PRIMÁRIO & PADRÃO SECUNDÁRIO \\
\hline \multirow{2}{*}{ PTS $\left(\mu \mathrm{g} / \mathrm{m}^{3}\right)$} & $24 \mathrm{~h}$ & $240(1)$ & $150(1)$ \\
\hline & Anual (média geométrica) & 80 & 60 \\
\hline \multirow{2}{*}{ FUMAÇA $\left(\mu \mathrm{g} / \mathrm{m}^{3}\right)$} & $24 \mathrm{~h}$ & $150(1)$ & $100(1)$ \\
\hline & Anual & 60 & 40 \\
\hline PARTICULAS INALÁVEIS - & $24 \mathrm{~h}$ & $150(1)$ & \multirow{2}{*}{ Igual ao padrão primário } \\
\hline$M P_{10}-\left(\mu \mathrm{g} / \mathrm{m}^{3}\right)$ & Anual & 50 & \\
\hline \multirow{2}{*}{$\mathrm{SO}_{2}\left(\mu \mathrm{g} / \mathrm{m}^{3}\right)$} & $24 \mathrm{~h}$ & $365(1)$ & $100(1)$ \\
\hline & Anual & 80 & 40 \\
\hline \multirow{2}{*}{$\mathrm{CO}\left(\mu \mathrm{g} / \mathrm{m}^{3}-\mathrm{ppm}\right)$} & $1 \mathrm{~h}$ & $40.000-35(1)$ & \multirow{2}{*}{ Igual ao padrão primário } \\
\hline & $8 \mathrm{~h}$ & $10.000-9(1)$ & \\
\hline $\mathrm{O}_{3}\left(\mu \mathrm{g} / \mathrm{m}^{3}\right)$ & $1 \mathrm{~h}$ & $160(1)$ & Igual ao padrão primário \\
\hline \multirow{2}{*}{$\mathrm{NO}_{2}\left(\mu \mathrm{g} / \mathrm{m}^{3}\right)$} & $1 \mathrm{~h}$ & 320 & 190 \\
\hline & Anual & 100 & Igual ao padrão primário \\
\hline
\end{tabular}

Observação: para PTS, fumaça, particulas inaláveis e $\mathrm{SO}_{2^{\prime}}$ os padrões primários e secundários relativos às médias de 24 horas podem ser ultrapassados apenas uma vez ao ano. Os padrões primários e secundários do CO de 8 horas e de 1 hora e do ozônio também não podem ser ultrapassados mais de uma vez ao ano. Não há permissão de ultrapassagem para o $\mathrm{NO}_{2}$.

(x) - Número de violações aceitas por ano.

Tabela 1-3 - Padrões Nacionais de Qualidade do Ar (PNQA) atualmente em vigor. Fonte: (Santana et al., 2012).

\subsection{Estimativas de emissão de poluentes atmosféricos na RMSP}

Modelos matemáticos podem ser utilizados como ferramenta na identificação e quantificação de fontes de material particulado através de metodologias que serão discutidas ao longo deste trabalho. Informações sobre as diferentes fontes de emissão de poluentes atmosféricos são úteis, auxiliando a interpretação destes modelos. Neste sentido, foram utilizadas estimativas extraídas do mais recente inventário de emissões da CETESB (CETESB, 2012) relativas a fontes móveis e fixas. A partir destas estimativas podemos obter a responsabilidade de 
alguns setores principais para as emissões de determinados compostos. A figura 1-7 apresenta a contribuição relativa por tipo de fonte para alguns poluentes.

Observamos que o setor veicular como um todo (veículos leves, pesados e motocicletas) é diretamente responsável por $40 \%$ das emissões do material particulado respirável $\left(\mathrm{MP}_{10}\right)$, em seguida aparecem ressuspensão do solo e formação de aerossol orgânico secundário, com $25 \%$ cada, e, finalmente, processos industriais, responsáveis por $10 \%$ das emissões do $\mathrm{MP}_{10}$ na RMSP. Contudo, deve-se considerar que uma importante parcela dos aerossóis orgânicos secundários presentes na atmosfera é atribuível a emissões veiculares, visto que podem estes ser originários da conversão gás-partícula de uma série de compostos orgânicos voláteis emitidos por automóveis. Assim, considerando também o impacto indireto, emissões veiculares podem ser responsáveis por até $65 \%$ das concentrações de material particulado observadas na RMSP.

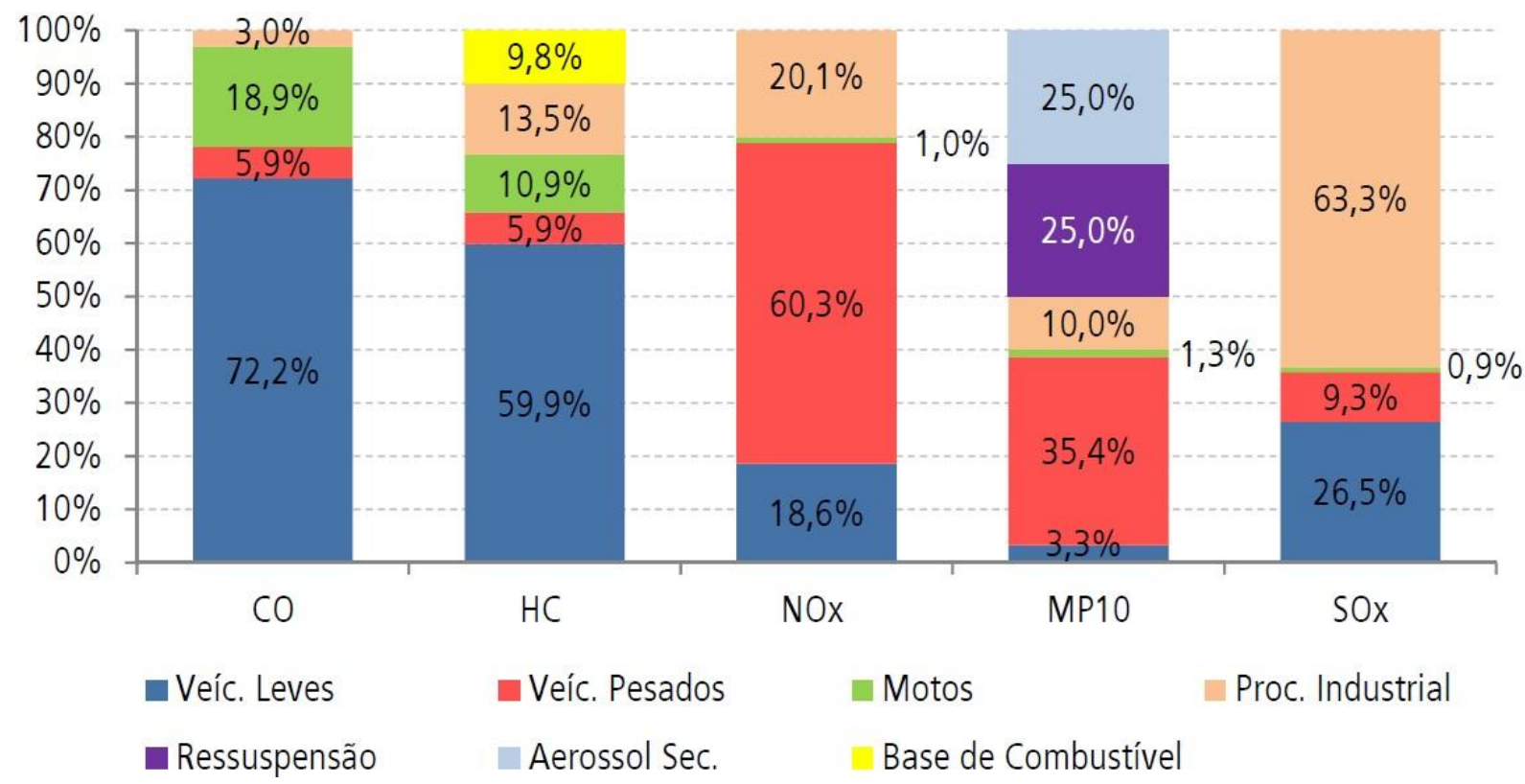

Figura 1-7 - Estimativas de emissão relativa dos diversos poluentes por tipos de fontes. São consideradas emissões de veículos leves e pesados, bem como motocicletas, processos industriais, ressuspensão de solo, formação de aerossol orgânico secundário e finalmente emissões de bases distribuidoras de combustíveis líquidos. Fonte: (CETESB, 2012).

Ainda na figura 1-7, verifica-se que as emissões veiculares são responsáveis praticamente por toda a concentração média observada para os gases NOx e CO, respondendo, 
respectivamente, por 80 e $97 \%$ do total, sendo que enquanto o inventário de emissões para o CO indica impacto predominante de veículos leves, as concentrações de $\mathrm{NO}_{\mathrm{x}}$ são atribuídas majoritariamente a veículos pesados.

Com relação à contribuição relativa das diferentes fontes de poluição do ar para o total de emissões de $\mathrm{SO}_{2}$ na RMSP, a CETESB atribui o impacto das fontes veiculares em 37\% do total das emissões de $\mathrm{SO}_{2}$. Essa informação será utilizada posteriormente para atribuição das contribuições veiculares nas componentes relacionadas a aerossóis de sulfato. 


\section{Objetivos deste trabalho}

O objetivo principal deste trabalho é a quantificação de fontes do material particulado na atmosfera da Região Metropolitana de São Paulo, com ênfase nas emissões veiculares. Objetivamos também caracterizar a componente carbonácea dos aerossóis. Para isto, buscouse:

- Caracterizar o material particulado atmosférico, tanto em sua componente inorgânica através de elementos traços, quanto nas diversas componentes carbonáceas;

- Quantificar as frações majoritárias na massa do material particulado fino em termos dos principais compostos orgânicos e inorgânicos e sua associação com as fontes de aerossóis, utilizando-se de técnicas de balanço químico de massa;

- Identificar e quantificar as principais fontes e processos de formação para a fração fina do aerossol atmosférico, assim como o perfil elementar de cada uma delas;

- Associar as diferentes componentes carbonáceas às emissões veiculares e a processos atmosféricos tais como a produção de aerossóis orgânicos secundários;

Observamos que embora seja bem estabelecido que emissões veiculares sejam a principal fonte de material particulado na RMSP, ainda faltam estudos quantitativos que avaliem o perfil elementar destas emissões veiculares. Procuramos também fazer um estudo abrangente com 4 estações amostradoras por um período de 1 ano, com número expressivo de amostras em cada estação para permitir uma análise estatística robusta. Além da determinação de elementos traços que é comum nestes estudos, pretendemos avançar agregando também análises de cromatografia iônica (IC) que permitem a determinação de nitratos e de outras espécies elementares como o sódio que não podem ser determinado por XRF. A medida em paralelo de diversos compostos por XRF e IC tais como $\mathrm{Ca}, \mathrm{Cl}, \mathrm{S}, \mathrm{Mg}$ e $\mathrm{K}$ auxiliam nos procedimentos de validação de dados, trazendo mais confiabilidade nas medidas de composição de aerossóis atmosféricos.

Outro importante diferencial deste trabalho foi o uso de análises detalhadas do material carbonáceo, determinado por análise térmica diferencial, que quantificou com métodos padrões o carbono orgânico e elementar em cada amostra, bem como suas diferentes frações. 
O estudo detalhado das componentes carbonáceas presentes na atmosfera vem se mostrando cada vez mais relevante, dada a significativa presença destes compostos no material particulado em áreas urbanas e remotas. Pretendemos também neste estudo integrar no modelamento receptor a componente gasosa, com as medidas da CETESB de CO e NOx, que auxiliam na separação da componente veicular, particularmente para emissões de veículos a diesel. 


\section{Metodologia}

A metodologia baseou-se na coleta de filtros de aerossóis atmosféricos em quatro locais da RMSP, e sua análise química para uma ampla gama de compostos. A vasta base de dados utilizada nesse trabalho é resultado medidas de poluentes atmosféricos realizadas em quatro estações de monitoramento de qualidade do ar na cidade de São Paulo, como parte integrante do projeto FONTES, fruto de parceria entre o Departamento de Química da Pontíficia Universidade Católica do Rio de Janeiro (PUC-Rio) e o Laboratório de Física Atmosférica do Instituto de Física da Universidade de São Paulo (LFA-IFUSP), e financiado pela Petrobrás (Petróleo Brasileiro S.A.).

O projeto FONTES (Quantificação das fontes de poluentes atmosféricos nas cidades de São Paulo e Rio de Janeiro e a importância das fontes veiculares) operou quatro estações de monitoramento no período de agosto de 2011 a janeiro de 2014, coletando cerca de 100 amostras de material particulado em cada uma delas. As quatro estações amostradoras estão próximas ou localizadas em estações de monitoramento fixas operadas pela CETESB (Companhia de Tecnologia de Saneamento Ambiental do Estado de São Paulo), o que possibilitou que fossem utilizadas medidas em paralelo da concentração de gases importantes, do ponto de vista de identificação de fontes, tais como o monóxido de carbono (CO), dióxido de enxofre $\left(\mathrm{SO}_{2}\right)$, óxidos de nitrogênio $\left(\mathrm{NO}_{\mathrm{x}}\right)$ e ozônio $\left(\mathrm{O}_{3}\right)$.

\subsection{As estações amostradoras do projeto FONTES}

As quatro estações amostradoras do projeto FONTES foram operadas em locais com diferentes situações de tráfego e impactos, e localizadas na cidade de São Paulo. A seguir, uma descrição detalhada das localizações e características de cada estação. A Figura 3-1 ilustra a localização destas 4 estações amostradoras. 


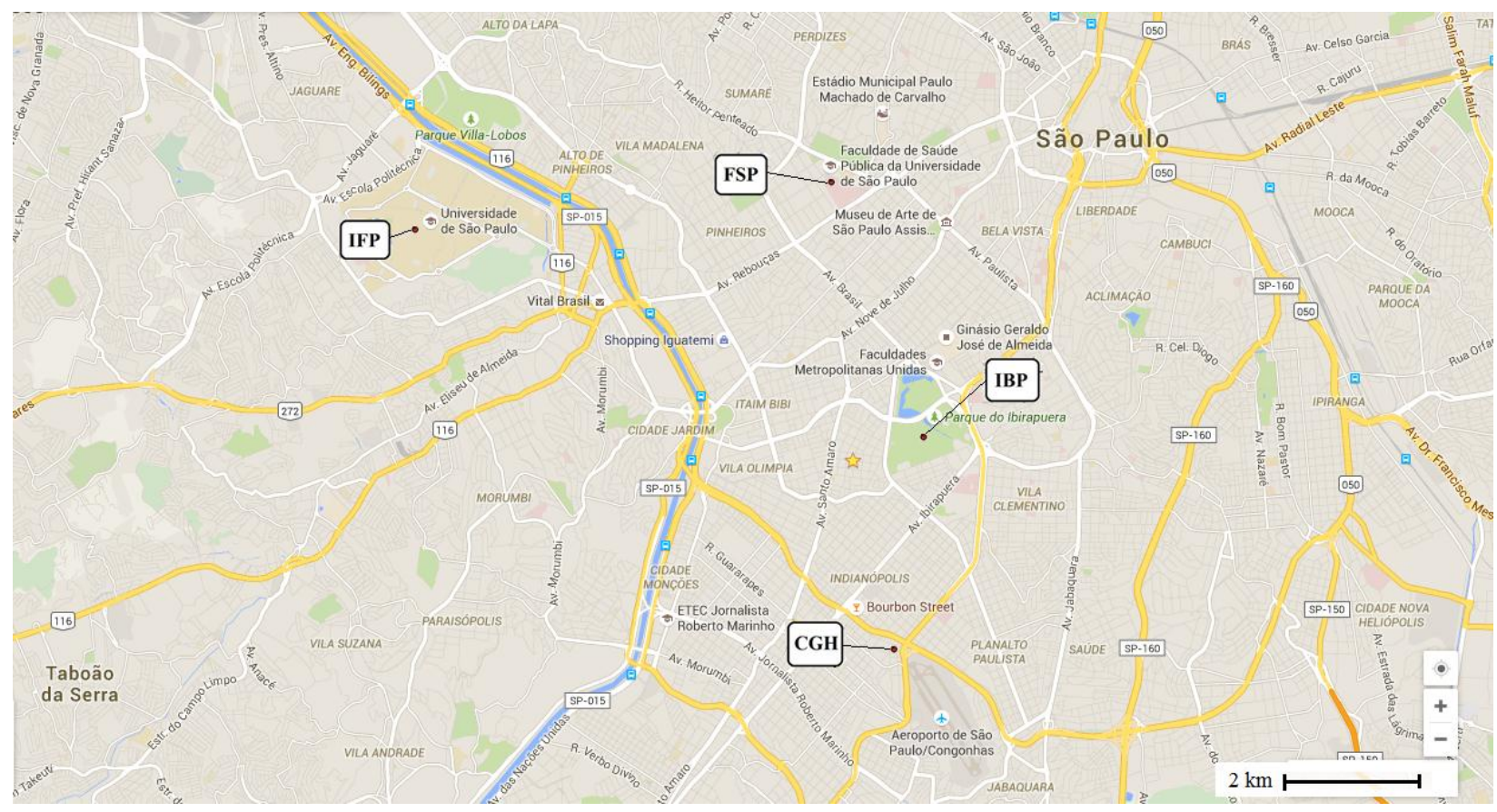

Figura 3-1 - Localização das estações amostradoras do projeto FONTES na Região Metropolitana de São Paulo.

\subsubsection{Estação amostradora de Congonhas (CGH)}

A estação de amostragem Congonhas (CGH) foi montada na Escola Municipal Prof. J. C. da Silva Borges, localizada na Alameda dos Tupiniquins, 1571, no bairro de Moema, zona sul de São Paulo. Das quatro estações de amostragem, Congonhas é a mais impactada por emissões veiculares devido a sua proximidade com a Avenida dos Bandeirantes, via de tráfego muito intenso. Esta estação é muito impactada por veículos pesados, tanto de ônibus fretados quanto caminhões (estes com circulação restrita das $06 \mathrm{~h}$ às $22 \mathrm{~h}$ em dias úteis). Além disso, a topografia local dificulta a dispersão de poluentes. Suas coordenadas geográficas são: latitude $23^{\circ} 36^{\prime} 29^{\prime}$ ' S, longitude $46^{\circ} 39^{\prime} 37^{\prime}$ ' $\mathrm{W}$ e altitude $760 \mathrm{~m}$.

\subsubsection{Estação amostradora de Cerqueira César - Faculdade de Saúde Pública (FSP)}

Localizada junto à Faculdade de Saúde Pública da Universidade de São Paulo (FSPUSP), na Av. Dr. Arnaldo, 715, Cerqueira César, na região central da cidade de São Paulo. A estação amostradora Cerqueira César (FSP) se caracteriza por alto impacto veicular, tanto de veículos pesados, como de veículos leves. A frota de veículos pesados é majoritariamente 
composta por ônibus metropolitanos. Suas coordenadas geográficas são: latitude $23^{\circ} 33^{\prime} 11$ ' S, longitude $46^{\circ} 30^{\prime} 22^{\prime}$ 'W e altitude de 817 m. A estação foi montada no teto do edifício da Faculdade de Saúde Pública da USP.

\subsubsection{Estação amostradora do Ibirapuera (IBP)}

A estação amostradora do Ibirapuera localiza-se na Av. Manoel da Nóbrega, 1985, dentro do Parque do Ibirapuera, em vasta área verde circundada por área densamente urbanizada. Está cercada por avenidas de tráfego intenso, porém as emissões veiculares num raio de $300 \mathrm{~m}$ da estação são praticamente nulas. Suas coordenadas geográficas são: latitude $23^{\circ} 34^{\prime} 55^{\prime}$ ' S, longitude $46^{\circ} 39^{\prime} 25^{\prime}$ ' W e altitude de $750 \mathrm{~m}$. O Parque do Ibirapuera é um dos pontos de maior concentração de ozônio na cidade de São Paulo, registrando frequentes ultrapassagens dos padrões de qualidade do ar, conforme discutidos na seção 1.4.

\subsubsection{Estação amostradora Instituto de Física da USP (IFP)}

A estação amostradora do IFP está situada na Cidade Universitária Armando Sales Oliveira, na Rua do Matão, Travessa R, 187, no Instituto de Física da USP (IF-USP). Essa estação, diferentemente de Cerqueira César e Congonhas, tem menor impacto de emissões veiculares diretas. A amostragem foi realizada no topo do edifício Oscar Sala (acelerador linear Pelletron), a 34 m de altura, o que permitiu a coleta de aerossóis em área com grande circulação atmosférica. Suas coordenadas geográficas são: latitude $23^{\circ} 56^{\prime} 09^{\prime}$ ' S, longitude $46^{\circ} 73^{\prime} 44^{\prime}$ ' W e altitude de $750 \mathrm{~m}$.

\subsection{A coleta do material particulado}

A coleta do material particulado foi realizada por meio de um sistema de filtros Nuclepore em série: o amostrador de particulado fino e grosso (AFG), também chamado Stacked Filter Unit, ou SFU. Esse sistema utiliza uma entrada com diâmetro de corte de $10 \mu \mathrm{m}$. As partículas com diâmetro $d_{p}$ inferior ao diâmetro de corte de $10 \mu \mathrm{m}$ são coletadas e divididas nas frações fina $\left(\mathrm{d}_{\mathrm{p}}<2.5 \mu \mathrm{m}\right)$ e grossa $\left(2.5 \mu \mathrm{m}<\mathrm{d}_{\mathrm{p}}<10 \mu \mathrm{m}\right)$. A vazão do amostrador é tipicamente de $17 \mathrm{~L}$ $\min ^{-1}$. O volume de ar amostrado é registrado em um integrador de volume, calibrado com um 
padrão primário de fluxo de ar. A figura 3-2 mostra um amostrador AFG como o utilizado nas coletas do projeto FONTES.

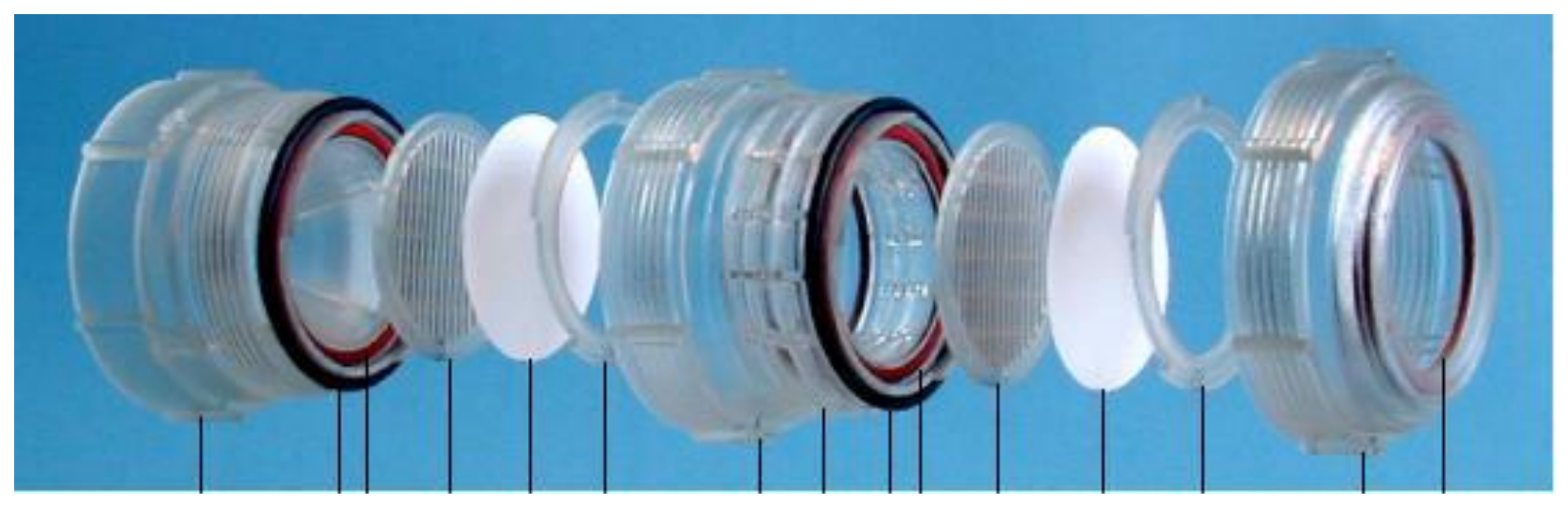

Figura 3-2- Fotografia mostrando os estágios do amostrador do particulado fino e grosso (Arana, 2014).

As partículas na fração grossa coletadas pelo $\mathrm{AFG}$ são depositadas em um filtro Nuclepore de diâmetro $47 \mathrm{~mm}, 8 \mu \mathrm{m}$ de tamanho dos poros, enquanto o material particulado fino é depositado em um filtro Nuclepore com poros de $0,4 \mu \mathrm{m}$. Com um fluxo de 17 litros por minuto, a separação entre as frações ocorre para partículas com diâmetro de 2.5 micrômetros.

Um segundo amostrador, em paralelo ao dos filtros Nuclepore, foi utilizado para a medida do material particulado carbonáceo. Equipado com filtros de quartzo e inlet com diâmetro de corte igual a $2,5 \mu \mathrm{m}$, esse segundo sistema possibilitou a análise quantitativa do carbono orgânico e elementar presentes na fração fina do aerossol. Os filtros de quartzo são mais indicados para a coleta de aerossóis carbonáceos a serem analisados por técnica termo-óptica, devido a sua estabilidade térmica, alta eficiência na coleta das partículas, rigidez e baixo nível de carbono nos filtros antes da coleta.

\subsection{Metodologia analítica}

A caracterização detalhada do material particulado na Região Metropolitana de São Paulo requereu a aplicação de diferentes metodologias analíticas derivadas das propriedades físicoquímicas dos diferentes tipos de aerossóis. A combinação de diferentes técnicas permitiu a determinação de um grande número de parâmetros considerados relevantes para a determinação 
das fontes de aerossóis através do uso de modelos receptores (Andrade et al., 1993a; 1993b; Artaxo, 1985; Artaxo et al., 1995; Artaxo e Castanho, 1998; Castanho, 1999; Gerab, 1996; Miranda et al., 2002).

As análises do material coletado nos filtros de Quartzo e Nuclepore (AFG) foram realizadas no Laboratório de Física Atmosférica (LFA) do Instituto de Física (IF) da Universidade de São Paulo (USP). As técnicas de gravimetria e de refletância foram empregadas para a determinação da concentração em massa do material particulado fino e grosso; e do seu conteúdo Black Carbon, respectivamente. Determinou-se também a composição iônica e elementar por meio de métodos de cromatografia iônica (IC) e fluorescência de raios-X (XRF). Por fim, a caracterização do material carbonáceo depositado nos filtros de quartzo foi feita através de análises termo-ópticas. Alguns parâmetros importantes na componente gasosa e na fase de particulado foram obtidos em colaboração com a CETESB, que opera estações fixas de monitoramento da qualidade do ar próximas aos locais onde foram feitas as campanhas de amostragem do projeto FONTES.

Nesta seção são apresentadas as diferentes técnicas analíticas utilizadas ao longo desse trabalho. Estão descritos também os princípios de funcionamento dos instrumentos utilizados, enfatizando-se a análise termo-óptica (TOA), empregada aqui para a caracterização de diferentes frações de carbono orgânico e elementar, por tratar-se de uma ferramenta recente e poderosa na quantificação de fontes do material particulado atmosférico. Nas seções 3.4 e 3.5 é feita também uma discussão sobre o uso de modelos receptores para a determinação de fontes do material particulado. É descrito, sucintamente, o modelo utilizado nesse trabalho, que foi a análise de fatores principais absoluta (APFA, do inglês Absolute Principal Factor Analysis).

\subsubsection{A análise gravimétrica da concentração de aerossóis}

A concentração em massa de material particulado nas frações fina e grossa depositada nos filtros Nuclepore (AFG) foi obtida através da análise gravimétrica. Nesta análise a massa dos filtros é medida antes e após a amostragem, partindo do princípio de que a diferença entre elas deve-se ao material depositado. Nesse trabalho, a análise por gravimetria foi feita utilizando-se 
uma micro balança eletrônica Metler XP6U com uma sensibilidade de $1 \mu \mathrm{g}$ em laboratório com temperatura $\left(20^{\circ} \mathrm{C}\right)$ e umidade relativa $(50 \%)$ controladas.

Antes da pesagem, os filtros são mantidos sob controle de temperatura e umidade relativa do ar por 24 horas e, para evitar que cargas eletrostáticas nos filtros alterem os resultados da pesagem, estes são expostos a uma fonte de ${ }^{210} \mathrm{Po}$, cuja radiação ionizante propicia a descarga elétrica. Os filtros têm $47 \mathrm{~mm}$ de diâmetro e, tipicamente massa de $16 \mathrm{mg}$ e $14 \mathrm{mg}$ antes da amostragem para os filtros fino e grosso, respectivamente. Após a amostragem, os filtros são pesados em laboratório novamente sob as mesmas condições.

Pode ocorrer um aumento da massa do filtro por razões que não sejam o depósito de material particulado durante a amostragem como, por exemplo, formação de micro-organismos no filtro ou a exposição deste à umidade. Para compensar esse efeito usam-se filtros chamados "brancos". Os filtros brancos são enviados para as estações de amostragem juntamente com os demais filtros, seguindo os mesmo procedimentos, entretanto os primeiros voltam ao laboratório sem que tenha sido feita a coleta. Determinada a massa do filtro branco, esse valor é então subtraído da massa do filtro amostrado. O valor de massa relativo ao chamado "branco" é da ordem de $40 \mu \mathrm{g}$ para o filtro Nuclepore fino e de $15 \mu \mathrm{g}$ para o filtro grosso.

Sabendo-se o volume de ar amostrado registrado no totalizador e a massa depositada no filtro e o valor do "branco", pode-se determinar a concentração do material particulado correspondente para cada filtro nas frações fina e grossa. O limite de detecção para concentração em massa de aerossóis é de cerca de $0,6 \mu \mathrm{g} \mathrm{m}^{-3}$, enquanto que a precisão é estimada em $5 \%$.

\subsubsection{A análise de black carbon equivalente por refletância}

A determinação das concentrações de black carbon equivalente (EBC) é feita pela técnica de refletância (absorção óptica). Na análise por refletância os filtros são submetidos a um feixe luminoso. Compostos carbonáceos com alta seção de choque de absorção de luz na região do visível presentes no filtro absorvem a luz do feixe, reduzindo sua intensidade. A fração do feixe refletida é então quantificada por um sensor fotoelétrico. No LFA foi desenvolvido um método óptico para analisar o BC presente nos filtros Nuclepore (Martins, 1999). As medidas são 
realizadas a partir de um refletômetro de luz branca difusa, comercializado pela Diffusion Systems com eficiência de resposta fotóptica em $550 \mathrm{~nm}$.

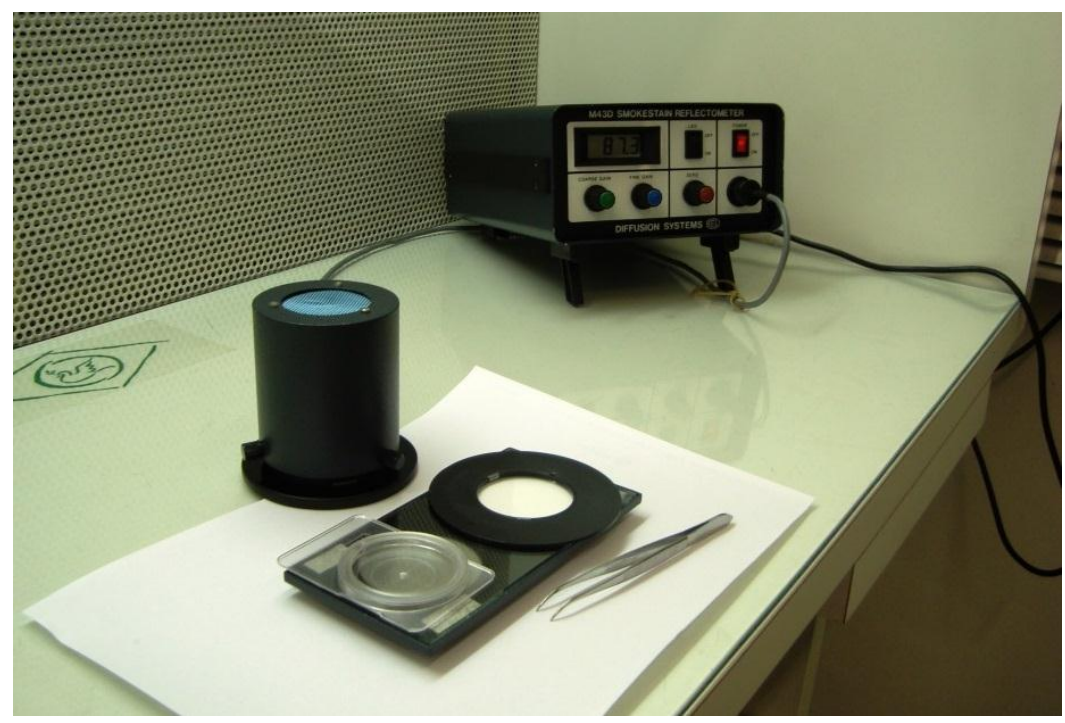

Figura 3-3 - A medida de "equivalent black carbon" $(\mathrm{EBC})$ foi feita no reflectrometro da Difusion System, calibrado por Ana Lucia Loureiro do LFA-IFUSP.

Métodos ópticos determinam as concentrações de black carbon equivalente (EBC). Essas técnicas, portanto, exigem o uso de um padrão de calibração para converter absorção óptica em concentração de EBC. A curva de calibração utilizada neste trabalho foi obtida empiricamente por Loureiro et al. (1994), e é dada pela equação abaixo, onde R é a refletância percentual; A é a área do filtro (neste caso, $14.4 \mathrm{~cm}^{2}$ ) e V é o volume de ar amostrado.

$$
B C\left(\mu \mathrm{g} \mathrm{m} m^{-3}\right)=\left[(30,90 \pm 0,15)-(15,454 \pm 0,007) \cdot\left(\frac{A}{V}\right) \cdot \log (\mathrm{R})\right] \quad(\text { Equação } 3 \cdot 1)
$$

Uma vez que o EBC presente na atmosfera deriva de fontes diversas com composição, estrutura e propriedades de absorção óptica distintas, os padrões de calibração podem afetar a análise. A presença de outros materiais absorvedores de luz pode conduzir a valores incorretos das concentrações de BC no filtro (Arana, 2014; Reisinger et al., 2008).

\subsubsection{A análise de compostos iônicos e elementares}

Foram empregadas as técnicas de cromatografia iônica, quantificando compostos iônicos presentes na fração solúvel em água; e fluorescência de raios-X, determinando a composição elementar de metais e semi-metais. 
A cromatografia iônica (IC, do inglês Ion Chromatography) é uma técnica capaz de separar e quantificar as concentrações de íons presentes em uma solução. A IC é um método de análise destrutivo, pois se faz necessária a diluição do material particulado presente no filtro em água. Nesta técnica mede-se somente a fração solúvel dos compostos presentes no material particulado. Nas análises por IC apresentadas nesse trabalho foram quantificados para os filtros Nuclepore, nas frações fina e grossa, os íons $\mathrm{Na}^{+}, \mathrm{K}^{+}, \mathrm{Mg}^{2+}, \mathrm{Ca}^{2+}, \mathrm{NH}_{4}{ }^{+}, \mathrm{Cl}^{-}, \mathrm{NO}_{3}{ }^{-}, \mathrm{SO}_{4}{ }^{2-}$, acetato, formiato e oxalato, para as estações IBP, IFP e FSP. As análises de IC foram feitas em equipamento DIONEX ICS-3000 (figura 3-4) pela equipe do Prof. José Marcus Godoy no Departamento de Química da Pontifícia Universidade Católica do Rio de Janeiro (PUC-Rio).
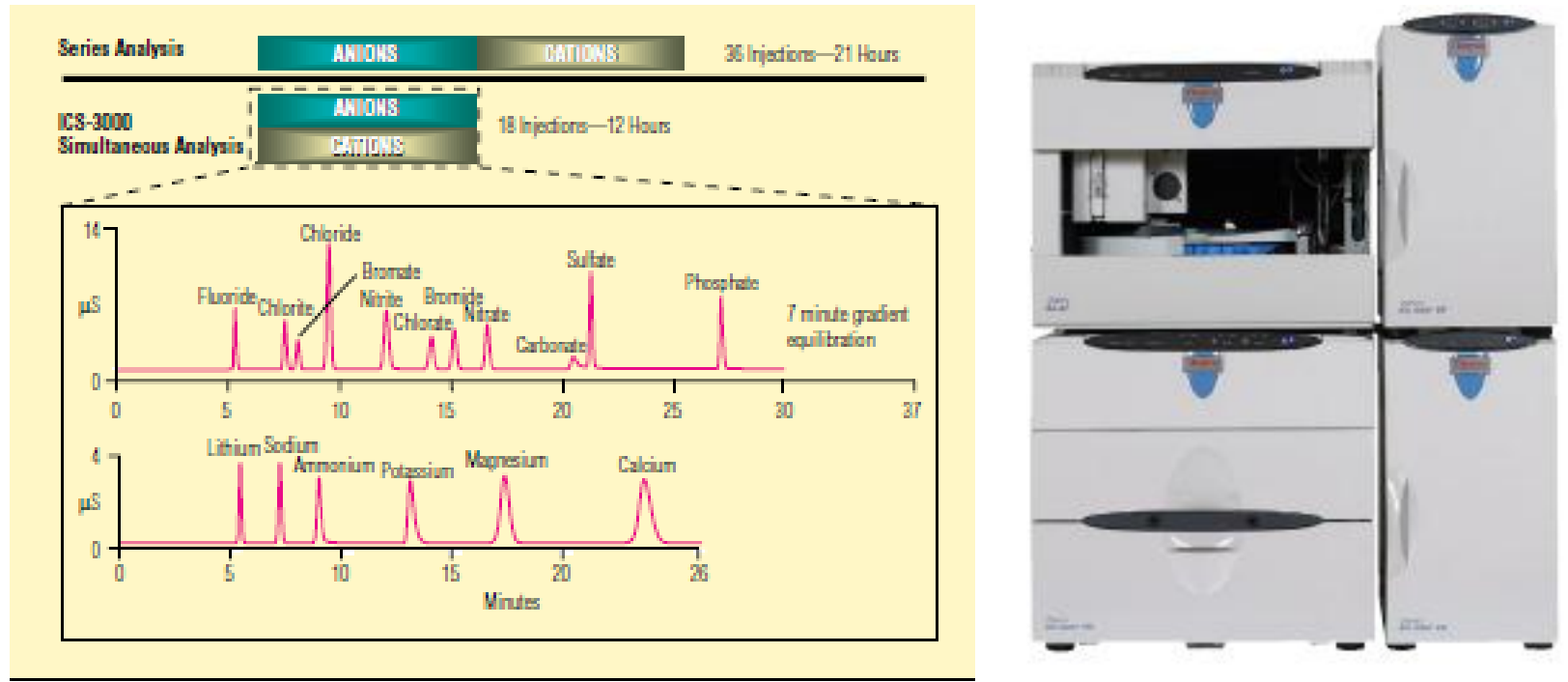

Figura 3-4- Ilustração do espectro de cromatografia iônica com a análise de cátions e ânions do equipamento Dionex ICS-3000 mostrado à direita nesta figura.

A técnica de espectrometria de fluorescência de raios $\mathrm{X}$ por dispersão de energia (EDXRF, do inglês Energy Dispersive X-Ray Fluorescence) é um método analítico de identificação e quantificação dos elementos químicos presentes nas amostras contendo material particulado. Trata-se de um método alternativo para outras técnicas analíticas, tais como ICP-MS (Inductively Coupled Plasma Mass Spectrometry) ou PIXE (Particle Induced X Ray Emission) (Spolnik et al. 2005). A EDXRF é um método não destrutivo, uma vez que não é necessária a dissolução das amostras, sendo possível irradiar a amostra muitas vezes. Esta técnica apresenta algumas vantagens como custo moderado, possibilidade de determinar simultaneamente um 
intervalo amplo de elementos e automação das medidas (Van Grieken e Markowicz 2002; Van Meel et al. 2009).

a)

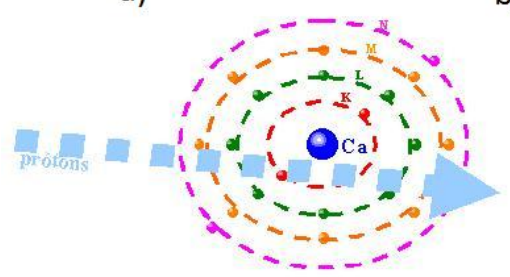

b)

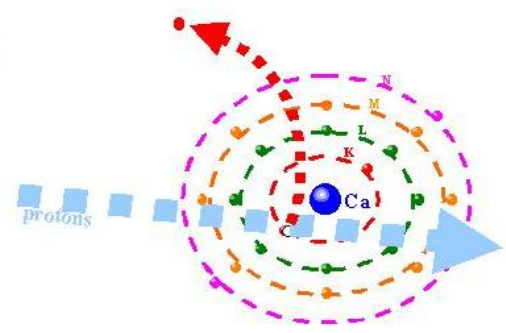

c)

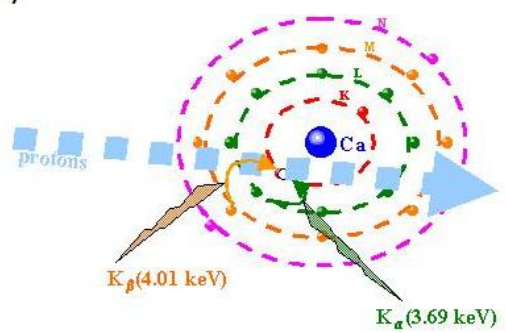

Figura 3-5 - Processo em que as partículas emitem raios X por fluorescência. a) Irradiação por partículas. b) o elétron é ejetado para fora da amostra. c) Emissão de raios X secundários quando a vacância é preenchida por outro elétron.

Sucintamente, na técnica de EDXRF, raios-X são produzidos no tubo de anodo Sc/W. Estes irradiam o alvo secundário que emite raios-X característicos e reflete uma parte dos raios$\mathrm{X}$ incidentes. Finalmente, a radiação que chega ao alvo é usada para irradiar a amostra. Conforme descrito na figura 3-5, quando a amostra de aerossóis é irradiada os elétrons das camadas internas dos átomos são excitados. Ao retornarem às camadas originais estes emitem raios-X secundários, cujas energias são características individuais de cada elemento e que serão medidos pelo detector de Germânio (PAN-32 Ge), ajustado para a detecção da dispersão de energia. Quando os raios-X passam pelo detector produzem pulsos elétricos. Estes sinais de corrente elétrica são processados e apresentados na forma de um espectro cps $\mathrm{mA}^{-1}$ versus $\mathrm{keV}$, (contagens por segundo por micro ampere e energia, respectivamente). Determinada a energia e a intensidade dos picos de raios-X característicos e o software calcula as concentrações de cada elemento a partir de parâmetros das curvas de calibração.

As análises por EDXRF para este trabalho foram feitas pela equipe técnica do LFA, no espectrômetro de fluorescência de raios X de dispersão de energia - Epsilon 5 da PANalytical, mostrado na figura $3-7$. 

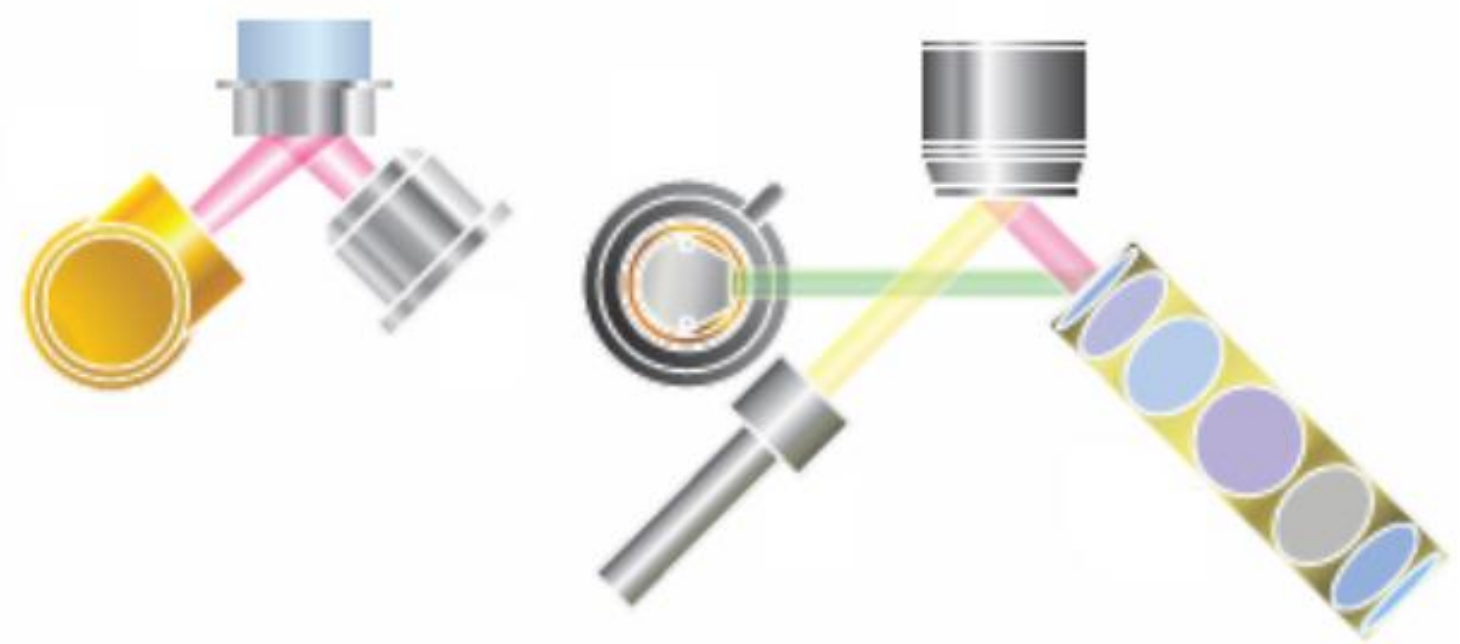

Figura 3-6- Esquema geral do princípio de funcionamento da análise por fluorescência de raios$\mathrm{X}$ de dispersão de energia - Energy Dispersive X-Ray Fluorescence. (EDXRF).

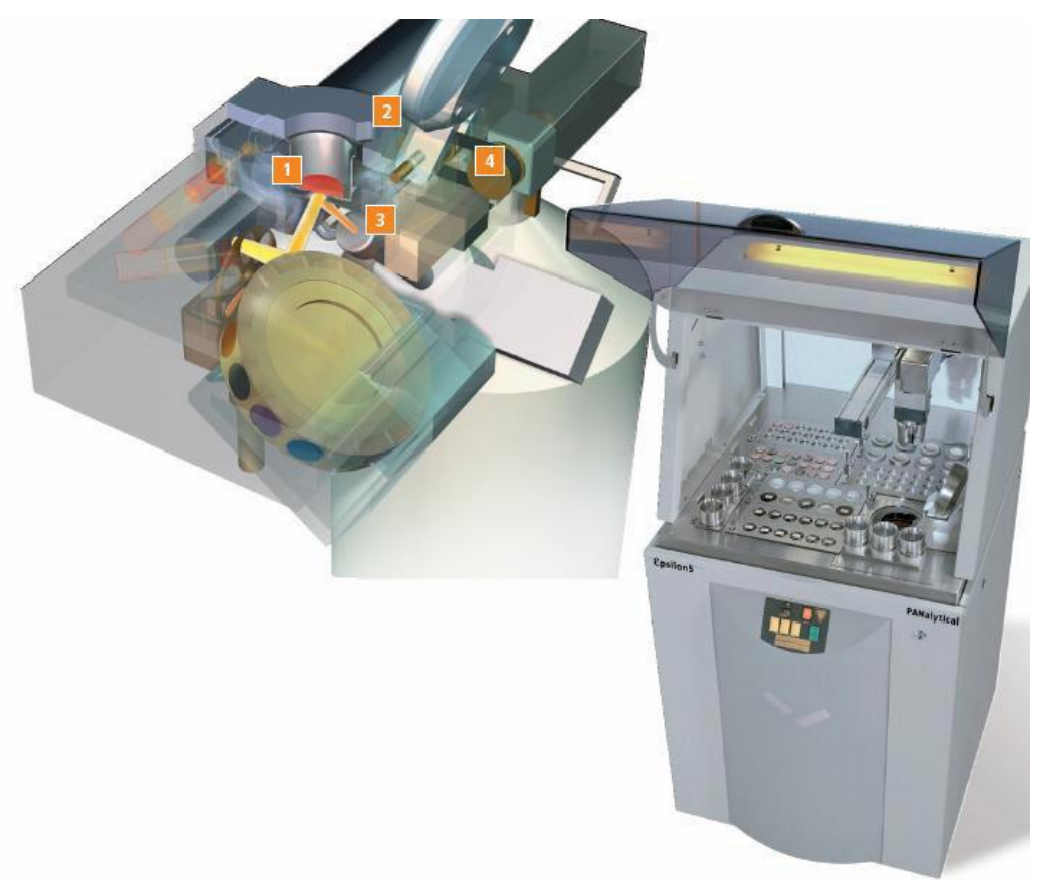

Figura 3-7 - Espectrômetro de Fluorescência de raios $\mathrm{X}$ Epsilon 5 (PANalytical) em operação no LFA/ IFUSP desde fevereiro de 2011. (1) Tubo de raios $\mathrm{X}$ de $\mathrm{Sc} / \mathrm{W}$ de alta voltagem; (2) Trajetória óptica com geometria tridimensional; (3) Alvos secundários para uma melhor condição de excitação das amostras; (4) Detector de raios $\mathrm{X}(\mathrm{PAN}-32 \mathrm{Ge})$.

Um extenso trabalho de calibração e otimização deste instrumento foi realizado por Arana (2014), no qual foram desenvolvidos padrões de calibração e condições de medida otimizadas a fim de reduzir os limites de detecção do instrumento. Os limites de detecção calculados para a maioria dos elementos foram abaixo de $10 \mathrm{ng} \mathrm{cm}^{-2}$. Alguns elementos $(\mathrm{P}, \mathrm{S}, \mathrm{Cl}$, 
$\mathrm{K}, \mathrm{Ca}, \mathrm{Cr}, \mathrm{Fe}$ e $\mathrm{Cu}$ ) apresentaram limite de detecção abaixo $3 \mathrm{ng} \mathrm{cm}^{-2}$, enquanto apenas $\mathrm{Na}, \mathrm{Mg}$ e Cd tiveram valores mais altos, em torno de $45 \mathrm{ng} \mathrm{cm}^{-2}$. Os limites de detecção calculados por Arana (2014) foram adotados também neste trabalho.

\subsubsection{A análise da componente carbonácea do aerossol}

A análise de carbono consiste na evolução do conteúdo total carbonáceo presente no material particulado (TC) e na determinação de sua distribuição em duas componentes, Carbono Orgânico (OC) e Carbono Elementar (EC), caracterizadas por diferentes propriedades físicoquímicas. Estas possuem diferente comportamento térmico. A premissa básica do método térmico é que o OC é volatilizado de uma amostra quando aquecido na ausência de oxigênio, enquanto o carbono elementar necessita da presença de oxigênio para sofrer combustão a altas temperaturas. Este tipo de análise, todavia, determina a massa de carbono presente nos componentes orgânicos do material particulado ao invés de determinar a massa total dos compostos orgânicos, isto é, incluindo a massa de outros elementos como $\mathrm{O}, \mathrm{H} \mathrm{e} \mathrm{N}$, presente nesses compostos. Pode-se estimar a concentração em massa dos orgânicos (OM) a partir do conteúdo de OC, para isso usa-se um fator multiplicativo. Valores da razão OM:OC em regiões urbanas impactadas por emissões veiculares por diesel e gasolina variam na literatura comumente de 1.2 a 1.6. Este fator é uma estimativa do peso molecular médio dos compostos orgânicos por grama de OC presente em uma amostra (Turpin et al., 2000).

Objetivando as análises das componentes carbonáceas do material particulado coletado em filtros foi utilizado o analisador de carbono termo-óptico OCEC do Sunset Laboratory. A figura 3-8 mostra um esquema do funcionamento do instrumento. Na análise termo-óptica a especiação carbono orgânico/elementar ocorre controlando-se a temperatura e a atmosfera (oxidante ou não) a qual a amostra é submetida. Um laser He-Ne atravessa a amostra continuamente a fim de monitorar sua transmitância para corrigir a formação pirolítica de EC, ou char, que ocorre durante a análise de alguns materiais.

Devido às altas temperaturas empregadas durante a análise, a coleta das amostras é feita em filtros de fibra de quartzo. Uma porção de $1 \mathrm{~cm}^{2}$ de cada filtro é analisada. Os conteúdos de OC e EC são reportados em $\mu \mathrm{g}$ de carbono por $\mathrm{cm}^{2}$ de área depositada e, portanto, a concentração total 
é obtida multiplicando esses valores pela área do filtro e dividindo-os pelo volume de ar total amostrado (Birch e Cary, 1996). As concentrações de carbono depositadas nos filtros para análise devem estar na faixa entre 5 e $300 \mu \mathrm{g} \mathrm{cm}^{-2}$ para OC e entre 1 e $20 \mu \mathrm{g} \mathrm{cm}^{-2}$, para EC.

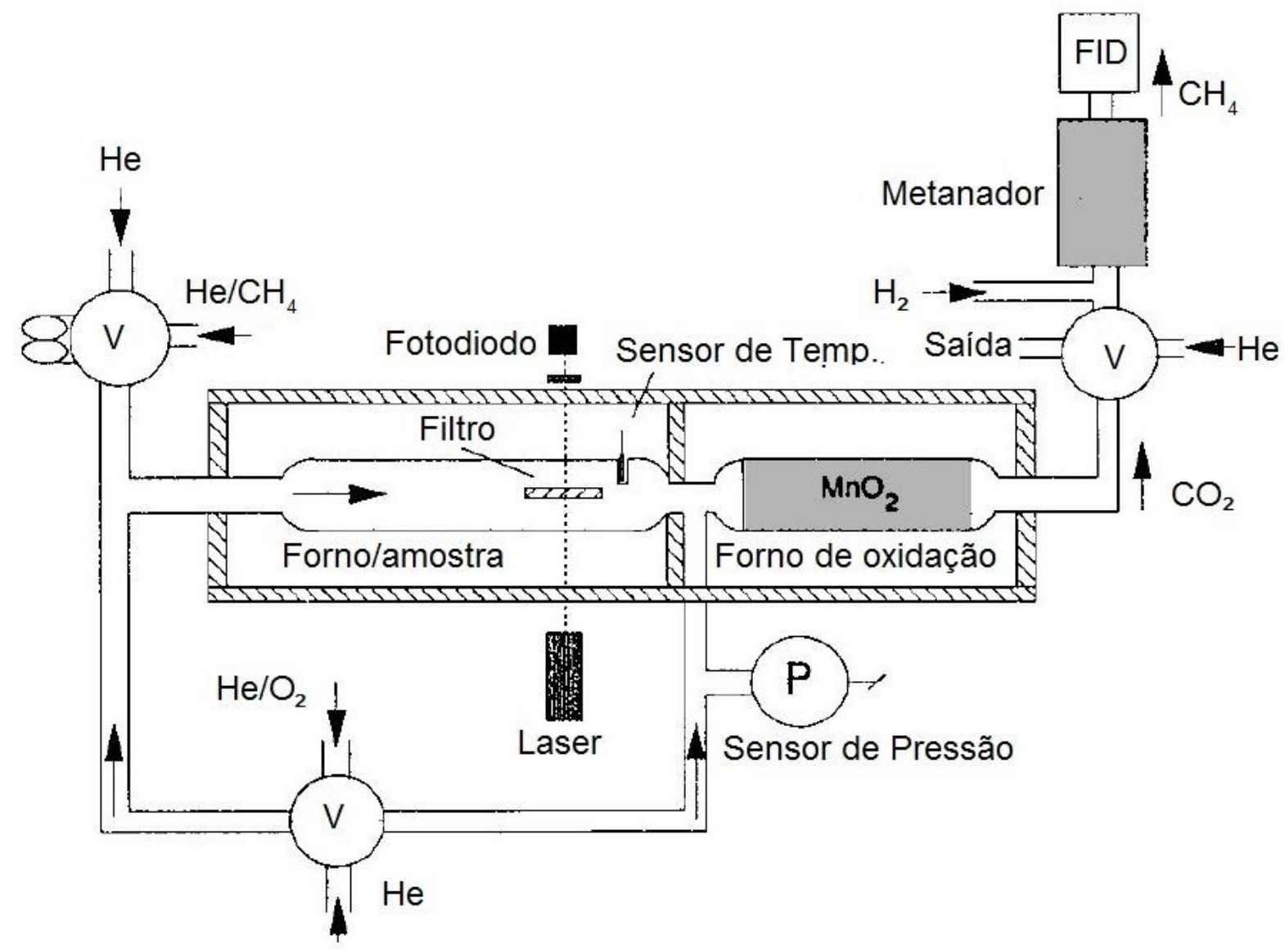

Figura 3-8 - Diagrama esquemático de funcionamento do analisador termo-óptico. Fonte: (Birch e Cary, 1996).

Um exemplo de saída do instrumento (termograma) é mostrado na figura 3-9. O procedimento de análise ocorre essencialmente em dois estágios. A primeira etapa ocorre em uma atmosfera totalmente livre de oxigênio composta apenas por gás hélio. A amostra é aquecida em quatro passos crescentes de temperatura até cerca de $820^{\circ} \mathrm{C}$. Nesse estágio todo o carbono orgânico e os carbonatos (quando presentes) são volatilizados e removidos do filtro. Alguns compostos orgânicos eventualmente são convertidos piroliticamente a carbono elementar (carbono pirolítico, ou PC) consequentemente a amostra torna-se mais escura. Até 30\% dos orgânicos podem ser convertidos nesse processo. A conversão pirolítica é monitorada 
continuamente durante toda a análise medindo-se a transmitância do laser que tende a diminuir nesse processo.

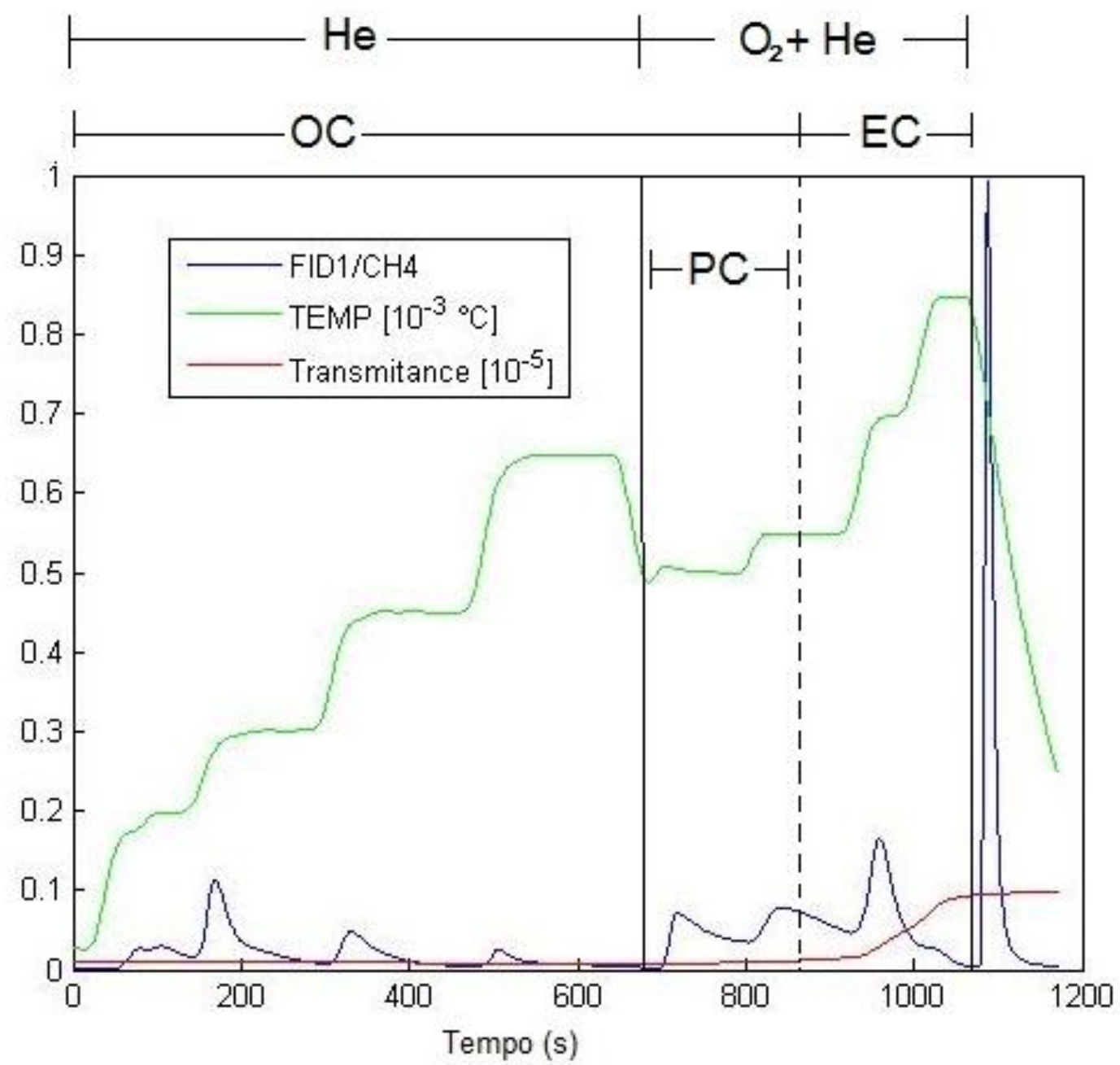

Figura 3-9 - Exemplo de termograma para uma amostra coletada na estação de Congonhas. As curvas correspondem à temperatura (verde), transmitância do filtro (vermelho) e resposta do FID (azul). Os picos verificados no primeiro estágio (atmosfera inerte de $\mathrm{He}$ ) correspondem às frações de $\mathrm{OC}$, enquanto os picos no segundo estágio (atmosfera oxidativa $\mathrm{He}+\mathrm{O}_{2}$ ) representam as frações de EC. A linha tracejada indica o split point.

Os compostos orgânicos vaporizados na primeira etapa são imediatamente oxidados a dióxido de carbono no próximo compartimento (forno de oxidação) contendo $\mathrm{MnO}_{2}$. O fluxo de gás $\mathrm{He}+\mathrm{CO}_{2}$ é então conduzido ao metanador, onde o dióxido de carbono é finalmente reduzido 
a metano, por sua vez, detectado pelo detector de ionização de chama (FID, do inglês Flame Ionization Detector).

No segundo estágio, o forno é resfriado a uma temperatura de $525^{\circ} \mathrm{C}$, o hélio puro no primeiro compartimento é trocado por uma mistura $2 \%$ de oxigênio/hélio e a amostra é novamente aquecida em passos até uma temperatura aproximada de $860^{\circ} \mathrm{C}$. Durante essa fase, tanto o EC presente originalmente na amostra como aquele produzido piroliticamente a partir de orgânicos no primeiro estágio são medidos. O carbono liberado da amostra na segunda etapa da análise é oxidado a $\mathrm{CO}_{2}$ agora devido à presença de oxigênio, mas, assim como na primeira fase, é convertido a metano e detectado pelo FID.

Devido à presença de oxigênio, o EC gerado piroliticamente (PC) é oxidado levando a um aumento na transmitância do filtro. Sua contribuição para o EC total consiste na quantidade de carbono que precisa ser oxidada para que a transmitância do filtro retorne ao seu valor inicial. O ponto exato onde isso ocorre ('split point') fraciona o conteúdo carbonáceo em OC e EC: o carbono volatilizado antes do split point é considerado orgânico (incluído carbonatos), já o carbono que evolui após o split point é considerado elementar.

Após a evolução de todo o carbono da amostra, uma quantidade de metano em concentração conhecida é injetada no forno. Calibra-se ao ser analisada cada uma das amostras com uma quantidade conhecida de carbono. Baseado na resposta do FID e na transmissão do laser, as quantidades de OC e EC são determinadas.

A acurácia do método é verificada a partir da análise de uma quantidade conhecida de carbono. Durante todo o período de análises deste projeto, foi realizado um procedimento de verificação para as concentrações de OC em um padrão de calibração, antes e após da rotina diária de laboratório. O padrão utilizado para OC é uma solução de sacarose $\left(42 \mu \mathrm{g} \mu \mathrm{L}^{-1}\right)$. Depositam-se um $\mu \mathrm{L}$ da solução em um filtro de quartzo pré-queimado (branco) então analisado e concentrações de OC dentro de $5 \%$ do valor esperado $\left(42 \mu \mathrm{g} \mathrm{cm}^{-2}\right)$ são aceitas. A precisão das análises é calculada pelo instrumento como um desvio padrão relativo e esteve em média entre 5 e $8 \%$ para as medidas de OC e EC neste trabalho. 


\subsubsection{Protocolos de temperatura: O protocolo EUSAAR_2}

A análise termo-óptica (TOA) é um método muito usual para a determinação quantitativa das frações carbonáceas do material particulado atmosférico. Atualmente, nesse tipo de análise, são usados diversos protocolos termo-ópticos contendo as informações sobre os passos de temperatura e o tempo de permanência em cada em cada estágio. Entretanto, o uso de diferentes protocolos de temperatura pode acarretar altas variações nos resultados da razão EC:TC, díspares entre si até por um fator 5. Geralmente, os diferentes protocolos determinam a mesma quantidade de carbono (TC), porém a discriminação entre OC e EC pode ser afetada. Idealmente, todo o OC é removido na fase de atmosfera inerte, enquanto o EC evolui a altas temperaturas na atmosfera oxidativa. Mas, na realidade, compostos orgânicos termicamente instáveis pirolisam no primeiro estágio formando o carbono pirolítico (PC) que será removido apenas na atmosfera com $2 \%$ de oxigênio, juntamente com o EC original. O cálculo incorreto da quantidade de PC formado pode influenciar significativamente a especiação de OC e EC. Propriedades ópticas (transmitância e refletância) da amostra são monitoradas antes e durante a análise a fim de corrigir o efeito da pirólise com uso de um laser. A premissa é de que, uma vez que o PC gerado durante o estágio em atmosfera inerte é absorvedor de luz, a transmitância e a refletância do laser diminuem à medida que o OC carboniza. No estágio seguinte, quando EC e PC são liberados do filtro, transmitância e refletância aumentam novamente. $\mathrm{O}$ ponto em que as propriedades ópticas retornam ao valor inicial (pré-pirólise) é usado para discriminar OC e EC (split point) (Cavalli et al., 2010).

Os protocolos tradicionalmente mais utilizados pela comunidade de ciências atmosféricas são IMPROVE (Chow et al., 1993) e NIOSH (Peterson e Richards, 2002). Esses protocolos diferem quanto aos passos de temperatura - mais elevadas para o NIOSH, cuja mais alta temperatura é de $900^{\circ} \mathrm{C}$, na fase $\mathrm{He}$; que para o IMPROVE, com máximo de $550 / 580^{\circ} \mathrm{C}$, também na fase $\mathrm{He}$ - e tempos de residência - tipicamente maiores para o IMPROVE que para o NIOSH. Além disso, o protocolo IMPROVE utiliza o método de refletância para realizar a correção pirolítica, enquanto o NIOSH adota o método de transmitância. Estudos (Chow et al., 2004; Chow et al., 1993; Conny et al., 2003) tem mostrado que essas diferenças podem alterar significativamente as quantidades de OC e EC medidas (Cavalli et al., 2010). 
Na correção pirolítica, a TOA assume que ao menos uma das seguintes hipóteses possa ser considerada: (1) O PC formado durante a fase inerte e o EC originalmente presente no filtro possuam a mesma seção de choque de atenuação. Dessa forma, pode-se desconsiderar o fato de que, eventualmente, PC e EC evoluam em conjunto e, portanto, todo o carbono evoluído após o split point seja equivalente à massa original de EC. (2) Alternativamente, todo o PC formado durante a fase He, evolua no estágio oxidativo primeiro que o EC originalmente no filtro. Desse modo, mesmo que os valores de $\sigma$ específicos de EC e PC sejam diferentes, a massa removida do filtro após o split point representaria o EC verdadeiro. Contudo, estudos recentes mostram que nenhuma dessas hipóteses pode ser considerada verdadeira e, portanto, existem influências inerentes na determinação OC/EC (Cavalli et al., 2010).

O protocolo utilizado neste trabalho foi o EUSAAR_2, desenvolvido a partir do projeto europeu EUSAAR (European Supersites for Atmospheric Aerosol Research), estudo conduzido com o objetivo de identificar as causas dessas diferenças no EC medido usando diferentes protocolos de temperatura. A fim de minimizar as principais influências, positivas e negativas, durante a análise, o protocolo satisfaz quatro critérios de otimização (Cavalli et al., 2010):

1. A carbonização é reduzida a fim de minimizar o efeito de alguma diferença nos valores de $\sigma$ específicos de EC e PC na precisão da correção óptica e, consequentemente, na discriminação entre OC e EC.

2. A evolução e/ou pirólise do OC é totalmente completa ao término da fase He para evitar que qualquer OC não evoluído/carbonizado, evolua na fase oxidativa. Isso evita que uma fração do OC não absorvedor de luz evolua após o split point superestimando a medida de EC.

3. A evolução do carbono absorvedor de luz (LAC) durante a fase inerte é minimizada. Espécies de LAC contém EC e, a sua evolução prematura altera medidas de EC pós-split point

4. Utiliza-se de estágios de dessorção múltipla a fim de reduzir a incerteza associada à posição do split point. 
Na tabela 3-1 é possível observar os estágios de temperatura e os tempos de residência em cada estágio para o protocolo EUSAAR_2 e, comparativamente, para os protocolos IMPROVE A e NIOSH 870.

\begin{tabular}{ccccccc}
\hline & \multicolumn{2}{c}{ EUSAAR_2 } & \multicolumn{2}{c}{ IMPROVE A } & \multicolumn{2}{c}{ NIOSH870 } \\
\cline { 2 - 7 } & $\mathbf{T ~}\left({ }^{\circ} \mathbf{C}\right)$ & $\mathbf{t}(\mathbf{s})$ & $\mathbf{T}\left({ }^{\circ} \mathbf{C}\right)$ & $\mathbf{t}(\mathbf{s})$ & $\mathbf{T}\left({ }^{\circ} \mathbf{C}\right)$ & $\mathbf{t}(\mathbf{s})$ \\
\hline \multirow{2}{*}{$\mathbf{1}^{\circ}$ Estágio } & 1 & 10 & 1 & 10 & 1 & 10 \\
Atmosfera & 200 & 120 & 140 & $*$ & 310 & 80 \\
inerte & 400 & 150 & 280 & $*$ & 475 & 80 \\
$($ He) & 650 & 180 & 480 & $*$ & 615 & 80 \\
& 1 & 180 & 580 & $*$ & 870 & 110 \\
\hline & 30 & & & 550 & 45 \\
$\mathbf{2}^{\circ}$ Estágio & 550 & 120 & 580 & $*$ & 550 & 45 \\
Atmosfera & 700 & 70 & 840 & $*$ & 625 & 45 \\
oxidativa & 850 & 80 & & & 700 & 45 \\
$\left(\right.$ He + $\left.\mathbf{O}_{2}\right)$ & & & & & 775 & 45 \\
& & & & & 850 & 45 \\
\hline
\end{tabular}

Tabela 3-1 Protocolos de temperatura disponíveis no analisador de carbono Sunset. São indicados passos de temperatura e tempo de residência em cada estágio. ${ }^{*} \mathrm{O}$ tempo total de medida varia de acordo com a concentração da amostra. No caso do protocolo IMPROVE A, o tempo total de medida pode alcançar 1 hora por amostra. Adaptado de Arana (2014).

No primeiro estágio, em atmosfera inerte de hélio puro, o carbono orgânico evolui ao longo de quatro passos de temperatura de $200,300,450$ e $650^{\circ} \mathrm{C}$, formando as frações carbonáceas $\mathrm{OC} 1, \mathrm{OC} 2$, OC3 e OC4, respectivamente, ordenadas em função de sua volatilidade. Durante o segundo estágio, quando a atmosfera oxidante (mistura de $\mathrm{O}_{2}$ e $\mathrm{He}$ ) é introduzida, o carbono elementar evolui. As frações EC1, EC2, EC3 e EC4 são quantificadas nesta etapa formando picos de resposta do FID nas temperaturas de 500, 550, 700 e $850^{\circ} \mathrm{C}$, respectivamente. Como discutido anteriormente, ao longo do primeiro estágio a fração menos volátil do carbono orgânico é pirolisada, este material torna-se refratário e evolui apenas na fase oxidante. No protocolo EUSAAR_2 a transmitância é monitorada ao longo de toda a análise: a formação do PC diminui o valor da transmitância ao longo da fase inerte, por se tornar absorvedor de luz como o EC original; então, na segunda etapa, todo o carbono medido até o momento em que a transmitância retorne ao seu valor original é quantificado como PC, originalmente OC. 
Finalmente, o OC total é definido operacionalmente como OC $=\mathrm{OC} 1+\mathrm{OC} 2+\mathrm{OC} 3+\mathrm{OC} 4+$ $\mathrm{PC}$, enquanto o $\mathrm{EC}$ total é definido como $\mathrm{EC}=\mathrm{EC} 1+\mathrm{EC} 2+\mathrm{EC} 3+\mathrm{EC} 4-\mathrm{PC}$.

\subsection{A análise multivariada na quantificação de fontes de poluentes}

Um dos pontos mais importantes no que diz respeito à caracterização dos aerossóis atmosféricos é a identificação e quantificação das suas fontes para a atmosfera. Aliado à determinação das concentrações elementares, o uso de modelos matemáticos é fundamental para a determinação da estrutura dessas fontes.

Modelos receptores são métodos de análise de dados aplicados para a obtenção de informações sobre as fontes de poluentes atmosféricos. Ao contrário dos modelos de dispersão, os modelos receptores trabalham com as concentrações elementares medidas em um filtro (receptor) e tentam estimar a origem desse material (Artaxo, 1985). O princípio fundamental dos modelos receptores é que a conservação de massa pode ser assumida e que o balanço químico de massa pode ser utilizado na identificação e quantificação das fontes de material particulado na atmosfera (Hopke, 2003).

Ainda segundo Hopke (2003), há um conjunto de restrições físicas naturais no sistema que devem ser consideradas no desenvolvimento de qualquer modelo para identificação e distribuição das fontes de material particulado:

1. O modelo deve explicar as observações, isto é, os dados originais devem ser reproduzidos pelo modelo.

2. As composições das fontes previstas pelo modelo devem ser sempre positivas, uma vez que uma fonte não pode ter concentração elementar negativa.

3. A contribuição de uma fonte para o material particulado não deve ser negativa; uma fonte não pode emitir massa negativa.

4. A soma das contribuições de massa elementar determinadas para cada fonte deve ser menor ou igual à massa medida para cada elemento; o todo não pode ser menor que a soma de suas partes. 
Neste trabalho os modelos receptores foram aplicados visando a identificação e quantificação de fontes poluidoras na atmosfera da Região Metropolitana de São Paulo. Foram utilizadas a Análise de Fatores Principais Absolutas (APFA) e a Matriz de Fatoração Positiva (PMF), que são modelos de análise multivariada.

\subsection{Métodos de análise multivariada}

Análises estatísticas multivariadas são métodos utilizados para a interpretação de grandes bases de dados, onde tanto o número de casos medidos como o número de variáveis consideradas é alto. Se duas ou mais variáveis nessa base de dados não forem completamente independentes, elas podem ser agrupadas através da criação de novas variáveis, reduzindo a complexidade do problema em questão, sem que ocorra uma perda relevante das informações iniciais. Além disso, os métodos de análise multivariada evidenciam relações existentes entre as diferentes essas (Gerab, 1996). Dentre as análises estatísticas multivariadas mais utilizadas em estudos de poluição do ar destacam-se a Análise de Fatores Principais Absoluta (APFA), Funções Ortogonais Empíricas (EOF), Análise de Cluster e a Fatoração de Matriz Positiva (PMF). Neste trabalho foram utilizadas as técnicas PFA, APFA e PMF (Hopke, 1991).

\subsubsection{Análise de Fatores Principais (PFA)}

A Análise de Fatores Principais ou Principal Factor Analysis (PFA) é um método de análise multivariada que foi desenvolvido por psicólogos para extrair o fator mental de inteligência a partir dos resultados de testes de QI. Posteriormente, foi empregado em áreas de geologia, economia e na determinação da estrutura de fontes de aerossóis atmosféricos (Artaxo, 1985). A partir da variabilidade temporal das concentrações elementares, a PFA reduz o número de variáveis necessárias para explicar as concentrações medidas. As novas variáveis, ortogonais entre si, serão combinação linear das variáveis originais e são escolhidas de modo a representar o máximo possível da inicial das medidas. Espécies que possuam variabilidade temporal semelhante são consideradas de uma mesma fonte, transporte ou processo de formação. Nessa análise não é necessária nenhuma premissa sobre o número de fontes ou a composição das mesmas (Arana, 2014; Artaxo, 1985). A PFA foi aplicada ao estudo de aerossóis pela primeira vez por grupos das universidades de Illinois, EUA (Hopke et al., 1976) e, a partir de então têm 
sido empregada sistematicamente no estudo da composição de aerossóis urbanos e remotos, mostrando-se uma análise eficiente na quantificação de fontes de material particulado (Andrade et al., 2012).

A base de dados inicial pode ser representada por uma matriz $n \times m$, onde $m$ é o número total de filtros coletados e $n$ é o número total de elementos medidos. Essa matriz inicial possui certa redundância de informações, pois alguns elementos são emitidos/formados pela mesma fonte e, portanto, não são ortogonais entre si. O objetivo da PFA é determinar uma matriz reduzida (de ordem $p \times m$ ) e de mais fácil interpretação, onde $p$ representa o número de fontes de aerossóis capazes de explicar a maior parte da variabilidade das espécies medidas $(p<n)$. Esta redução de dimensão é obtida matematicamente através da análise de autovalores e autovetores. Os elementos dos $p$ vetores, chamados fatores principais, são as novas variáveis construídas a partir das variáveis originais, agrupando aquelas que possuem maior correlação (Arana, 2014).

Henry et. al (2002) sugerem que, para resultados estatisticamente significativos, a base de dados deva satisfazer a seguinte relação:

$$
n>30+\frac{(m+3)}{2}
$$

Onde n é o número de casos e m o número de variáveis. As aplicações da PFA empregadas neste trabalho, com um número de variáveis entre 30 e 40, exigem n > 52. Uma vez que foi coletada uma centena de filtros em cada estação amostradora, a PFA é adequada para este trabalho.

A PFA baseia-se na seguinte equação:

$$
C_{i j}=\sum_{k=1}^{p} \alpha_{i k .} F_{k j}
$$

onde:

$C$ (m x n) é a matriz dos dados originais. Neste caso representando a concentração das $\mathrm{n}$ espécies para $\mathrm{m}$ amostras.

$\alpha$ é a matriz ( $\mathrm{n} \times \mathrm{p}$ ) representando a associação entre cada variável com os fatores selecionados.

$F$ é a matriz (p x m) representando o impacto de cada fator na amostra i. 
$m$ é o número total de filtros medidos

$n$ é o número total de elementos medidos

$p$ é o número total de fatores principais.

$i$ - variáveis $\left(\mathrm{PM}_{2.5}, \mathrm{BC}, \mathrm{OC}, \mathrm{Na}, \ldots\right.$, espécie $\left.\mathrm{n}\right)$

$j-\operatorname{amostras}($ filtro 1, filtro2, filtro3, ..., filtro $\mathrm{m}$ )

$k$ - fatores principais (fonte 1, fonte 2 , fonte $3, \ldots$, fonte $\mathrm{p}$ )

A PFA utiliza-se apenas das concentrações $C_{i j}$ para prever o número de fontes e estimar simultaneamente os $\alpha_{i k}$ e $F_{k j}$.

Para eliminar os problemas decorrentes das diferentes métricas de cada variável, a distribuição das concentrações $C_{i j}$ é normalizada para média zero e variância igual a 1 , procedimento que torna comparáveis os valores absolutos de concentração das variáveis, uma vez que estes podem diferir por ordens de magnitude (Artaxo, 1985; Gerab, 1996). A matriz das concentrações normalizadas é dada por:

$$
Z_{i j}=\frac{\left(C_{i j}-\bar{C}_{j}\right)}{\sigma_{C_{j}}}
$$

Onde:

$\bar{C}_{j}=\frac{1}{m} \sum_{i=1}^{m} C_{i j}$, é o valor médio da concentração da variável $\mathrm{j}$.

$\sigma_{C_{j}}^{2}=\frac{1}{m-1} \sum_{i=1}^{m}\left(C_{i j}-\bar{C}_{j}\right)^{2}$, é o desvio padrão da variável j.

Uma vez que as variáveis são correlacionadas entre si, é possível truncar o modelo em p fatores principais $(\mathrm{p}<\mathrm{n})$, explicando uma fração significativa da variabilidade dos dados.

Na PFA assume-se que a concentração observada para cada variável é combinação linear da contribuição de cada uma das $p$ fatores principais (eventualmente, fontes de material particulado) às quais se atribui a composição do sistema. O número p de fatores principais é determinado empregando-se uma análise de autovetores e autovalores, técnica que tenta simplificar a descrição de um sistema determinando o número mínimo de novas variáveis necessárias para reproduzi-lo. 
O primeiro passo na análise de autovetores e autovalores é calcular uma matriz de dispersão, que mede o grau de relação entre as variáveis. Os dois tipos básicos de matrizes de dispersão são a matriz de covariância e a matriz de dispersão. Numa matriz de correlação, os dados estão em escalas tais que cada variável têm o mesmo peso, enquanto a matriz de covariância é calculada sem que os dados tenham sido padronizados (Hopke, 1991). Na PFA calcula-se a matriz de correlação, uma vez que a matriz de dados está normalizada.

A decomposição da matriz de dados $\mathrm{Z}$ no produto das duas matrizes é feita a partir da diagonalização da matriz de correlação (D) pela solução de um problema de autovalores e autovetores. Encontram-se os $n$ autovalores $(\lambda)$ da matriz de correlação de dados a partir da equação abaixo:

$$
\operatorname{det}(D-\lambda I)=0
$$

Onde I é a matriz identidade.

Cada autovalor representa a variância de um fator principal. A variância obtida para um fator indica o número de variáveis que este fator explica. A soma das variâncias de todos os fatores principais deve resultar no número total de variáveis, isto é:

$$
\sum_{j=1}^{n} \lambda_{j}=\lambda_{1}+\lambda_{2}+\lambda_{3}+\cdots+\lambda_{n}=n
$$

Determinou-se uma matriz de $n$ amostras por $n$ fatores principais, que representa a solução exata do problema onde $100 \%$ da variabilidade original dos dados é explicada. Todavia, o objetivo central da PFA é determinar uma matriz m x p reduzida e de mais fácil interpretação. Assim, o próximo passo é truncar o espaço dimensional das $n$ variáveis em $p$ fatores $(\mathrm{p}<\mathrm{n})$ que expliquem uma fração significativa da variância total dos dados, bem como da variância de cada uma das variáveis iniciais individualmente.

Como critério para a escolha do número $p$ de fatores principais, em consistência com outros trabalhos focados na quantificação de fontes através do uso de modelos receptores (Arana, 2014; Castanho, 1999; Gerab, 1996), optou-se por reter os fatores cujos autovalores $\lambda$ sejam 
maiores do que um após a rotação VARIMAX (discutida a seguir). Tal escolha baseia-se no fato de que fatores com autovalor menor que uma unidade carregam, em princípio, menos informação sobre a base de dados do que uma única variável, uma vez que o autovalor mostra o número de espécies que aquele fator explica. Contudo, autovalores imediatamente abaixo de um foram analisados com maior cautela, podendo vir a ser considerados, tendo em vista a comunalidade explicada para as variáveis.

Cada amostra pode ser vista como um ponto no espaço n-dimensional, onde n é o número de variáveis que compõe a base de dados. A PFA consiste na redução dimensional deste espaço. Cada amostra passa a ser representada como combinação linear de uma base ortogonal com dimensão $\mathrm{p}$, onde $\mathrm{p}<\mathrm{n}$ é o número de fatores principais. O significado físico desses fatores principais, contudo, não é de interpretação direta.

Para melhor interpretação dos fatores principais efetua-se uma rotação dos autovetores, preservando sua ortogonalidade, mas maximizando a variância dos quadrados dos loadings para cada fator, de modo que estes assumam valores mais próximos de um. O método utilizado neste trabalho, chamado estrutura simples ou VARIMAX, baseia-se na maximização da seguinte função (Castanho, 1999):

$$
V=\frac{1}{p} \sum_{j=1}^{m}\left[\sum_{i=1}^{p} l_{i j}{ }^{4}-\frac{1}{p}\left(\sum_{i=1}^{p} l_{i j}^{2}\right)^{2}\right]
$$

Onde V é a matriz de rotação varimax; $l$ são os autovetores; e $p$ é o número de fatores principais retidos.

\subsubsection{Análise de Fatores Principais Absoluta (APFA)}

Se a normalização não fosse necessária na PFA, a contribuição de cada fator para cada amostra em massa seria obtida diretamente. A PFA fornece, entretanto, apenas os Factor Loadings, contendo associações entre as variáveis antigas e os fatores principais retidos na análise; e os Factor Scores, elementos da matriz das novas variáveis normalizadas (fatores principais) que indicam a importância dos fatores principais retidos para cada uma das amostras. 
A partir destas informações é possível determinar a contribuição de cada fonte (fator principal) para o valor absoluto de cada uma das variáveis medidas. Este procedimento de estimativa dos perfis absolutos de emissão para cada fonte é chamado Análise de Fatores Principais Absoluta ou Absolute Principal Factor Analysis (APFA).

Diferentes métodos foram desenvolvidos para quantificar a contribuição das concentrações na composição das componentes retidas por APFA. O método utilizado neste trabalho, no qual é introduzida uma amostra na qual as concentrações de todas as variáveis são nulas, está descrito detalhadamente em Gerab (1996) e em Swietlicki et al. (1996). Neste método redefine-se uma nova grandeza, os Absolute Principal Factor Scores (APFS). Cada APFS é um vetor contendo a variabilidade associada ao respectivo fator principal. Pode-se então calcular a contribuição da fonte k para uma variável j na amostra i através de uma regressão linear múltipla entre os valores obtidos para uma variável e os APFS, dessa forma as concentrações podem ser expressas como uma combinação linear dos APFS associados a cada um dos $p$ fatores principais retidos.

$$
C_{i j}=\sum_{k=1}^{p} \beta_{j k} \cdot A F S_{i k}
$$

Onde:

$\mathrm{C}_{i j}$ - concentração da espécie j na amostra i

$\beta_{j k}$-coeficiente da regressão linear entre as concentrações da espécie $j$ e o APFS associado à fonte $k$.

AFSik - valor do APFS associado à fonte $\mathrm{k}$ na amostra $\mathrm{i}$.

$\beta_{j k}$. $A F S_{i k}$ - representa a contribuição da fonte $\mathrm{k}$ na concentração da variável $j$ medida na amostra $i$.

\subsubsection{O modelo de Matriz de Fatoração Positiva (PMF)}

A matriz de fatoração positiva (PMF, do inglês Positive Matrix Factorization) é um modelo multivariado com os mesmos princípios básicos da PFA. No entanto, no PMF há a imposição de vínculos físicos ao problema estatístico, como a ponderação das variáveis de acordo com as respectivas incertezas e a não ocorrência de fontes negativas. Este modelo se baseia no ajuste de mínimos quadrados entre as variáveis originais e as novas variáveis. 
De forma sucinta, o método PMF possibilita a identificação de fontes poluidoras na atmosfera ao utilizar o erro conhecido (ou estimado) da matriz de dados e impor restrições nãonegativas nos fatores resultantes (Paterson et al. 1999; Ulbrich et al. 2012). O método assume que uma matriz $\mathbf{X}$ de tamanho $m \times n$, sendo $m$ constituintes e $n$ observações pode ser fatorado em matrizes $\mathbf{F}(p \times m)$ and $\mathbf{G}(n \times p)$ com a matriz residual $\mathbf{E}(n \times m)$, i.e.

$$
X i j=\sum_{k=1}^{p} G_{i k} F_{k j}+E_{i j}
$$

O número de linhas em $\mathbf{F}$ e o número de colunas em $\mathbf{G}$ são conhecidos como o número de fatores, $p$. Cada coluna de $\mathbf{F}$ representa uma única fonte de poluentes e as colunas de $\mathbf{G}$ contém a intensidade da fonte em cada momento de observação. Se G é adimensional, com um valor médio de cada coluna igual a um, então os elementos de $\mathbf{F}$ são os valores médios de cada parâmetro associado a uma fonte particular. O método PMF minimiza então Q, a soma dos quadrados dos resíduos pesados inversamente pela variação dos dados. A restrição de não negatividade é aplicada em cada elemento das matrizes $\mathbf{F}$ e $\mathbf{G}$ ao minimizar $Q$, definido como:

$$
Q=\sum_{i=1}^{n} \sum_{j=1}^{m}\left[\frac{E_{i j}}{s_{i j}}\right]^{2}
$$

O valor $S_{i j}$ é o desvio padrão de $X_{i j}$. É desejável obter o valor $Q$ igual aos números de elementos de $\mathbf{X}$, como isto representa a situação onde o desvio padrão específico é igual aos resíduos da análise do fator. A equação 3-9 pode ser então resolvida utilizando um algoritmo iterativo. 


\section{Resultados obtidos}

Neste capítulo passamos a apresentar os resultados obtidos, iniciando com uma discussão das concentrações medidas e sua modelagem com o método de Chemical Mass Balance (CMB). A partir daí apresenta-se as análises de modelos multivariados incluindo a fração carbonácea.

\section{1 - Caracterização química do material particulado na RMSP}

A concentração em massa do material particulado nas frações fina e grossa medida nos filtros Nuclepore foi determinada através da técnica de gravimetria. Esses resultados são apresentados na tabela 4-1. Observa-se que as concentrações médias obtidas para as estações IFP, FSP e IBP são muito próximas tanto na moda fina como na moda grossa. A consistência encontrada entre os resultados de estações amostradoras distintas indica um material particulado fino relativamente bem misturado sobre a atmosfera da RMSP. No caso da estação amostradora de CGH não foi possível discriminar as frações fina e grossa do material particulado inalável $\left(\mathrm{PM}_{10}\right)$ em todos os filtros. Nesta estação são registradas concentrações altíssimas de $\mathrm{PM}_{10} \mathrm{em}$ virtude das altas taxas de emissão veicular locais. Por esse motivo os filtros Nuclepore apresentaram frequentemente redução do fluxo de ar em decorrência da alta taxa de material particulado depositado, mesmo para amostragem no período de tempo de $24 \mathrm{~h}$. Neste trabalho, não analisamos o fracionamento do material particulado fino e grosso, mas a soma destas componentes que fornecem o $\mathrm{PM}_{10}$. Mesmo para o $\mathrm{PM}_{10}$, as medidas em Congonhas têm maior incerteza.

\begin{tabular}{|c|c|c|c|c|c|c|c|c|c|c|}
\hline & \multicolumn{4}{|c|}{$\begin{array}{l}\text { Material particulado fino } \\
\qquad\left(\mu \mathrm{g} \mathrm{m}^{-3}\right)\end{array}$} & \multicolumn{4}{|c|}{$\begin{array}{l}\text { Material particulado grosso } \\
\left(\mu \mathrm{g} \mathrm{m}^{-3}\right)\end{array}$} & \multirow{2}{*}{$\begin{array}{c}\mathbf{P M}_{\mathbf{1 0}} \\
\left(\mu \mathrm{g} \mathrm{m}^{-3}\right) \\
\text { Média }\end{array}$} & \multirow[b]{2}{*}{$\mathbf{N}$} \\
\hline & Média & $\sigma$ & Máx. & Min & Média & $\sigma$ & Máx. & Min & & \\
\hline IBP & 11.96 & 4.95 & 28.55 & 3.47 & $\begin{array}{l}18.08 \\
\end{array}$ & 15.26 & 101.15 & 3.99 & 30.04 & 100 \\
\hline IFP & 9.57 & 4.82 & 26.87 & 2.98 & 15.89 & 13.40 & 97.26 & 2.01 & 25.46 & 101 \\
\hline FSP & 11.13 & 4.57 & 30.74 & 3.58 & 15.14 & 9.63 & 61.38 & 3.87 & 26.37 & 100 \\
\hline CGH & * & $*$ & $*$ & $*$ & * & * & $*$ & * & 34.01 & 103 \\
\hline
\end{tabular}

Tabela 4-1 - Análise descritiva das concentrações de material particulado nas frações fina e grossa para as estações amostradoras IFP, FSP, IBP e CGH, onde $\sigma$ representa o desvio padrão da média e $\mathrm{N}$ o número de casos medidos. O material particulado inalável $\left(\mathrm{PM}_{10}\right)$ é dado pela soma das frações fina e grossa. ${ }^{*} \mathrm{Na}$ estação amostradora de CGH não foi possível discriminar as frações fina e grossa. 
Nas estações amostradoras IFP, FSP e IBP foram observadas concentrações entre 10 e $12 \mu \mathrm{g} \mathrm{m}^{-3}$ na fração fina e na faixa de 16 a $18 \mu \mathrm{g} \mathrm{m}^{-3}$ na fração grossa. Enquanto nestas estações a soma das frações fina e grossa é de 25 a $30 \mu \mathrm{g} \mathrm{m}^{-3}$, no sítio de CGH a concentração média de $\mathrm{PM}_{10}$ observada foi de $34.0 \mu \mathrm{g} \mathrm{m}^{-3}$. A estação $\mathrm{CGH}$ é a de mais alto impacto por emissões veiculares próximas ao amostrador. Tal característica justifica a média para $\mathrm{PM}_{10} \mathrm{em}$ Congonhas seja $25 \%$ maior que a média nas demais estações amostradoras.

As séries temporais das concentrações em massa do material particulado discriminado nas frações fina e grossa para os sítios IBP, IFP e FSP são mostradas nas figuras 4-1, 4-2 e 4-3, respectivamente. Nos três casos verifica-se alta variabilidade nas concentrações médias ao longo do período de amostragem. Na fração fina é possível observar dias com concentrações abaixo de $5 \mu \mathrm{g} \mathrm{m}^{-3}$ (principalmente em IFP), como também concentrações frequentemente superiores a 20 $\mu \mathrm{g} \mathrm{m}^{-3}$. De acordo com Castanho (1999), essa grande variabilidade nas concentrações de material particulado atmosférico na RMSP está intimamente relacionada às variações nas condições meteorológicas. Em condições de alta pressão, associadas a condições termodinâmicas de inversões térmicas durante a noite e, portanto, desfavoráveis à dispersão de poluentes, há uma forte tendência a observar mais altas concentrações; enquanto concentrações mais baixas estão associadas à entrada de sistemas meteorológicos trazendo chuvas e processos de instabilidade atmosférica. Finalmente, a Figura 4-4 apresenta a série temporal de CGH para $\mathrm{PM}_{10}$. 


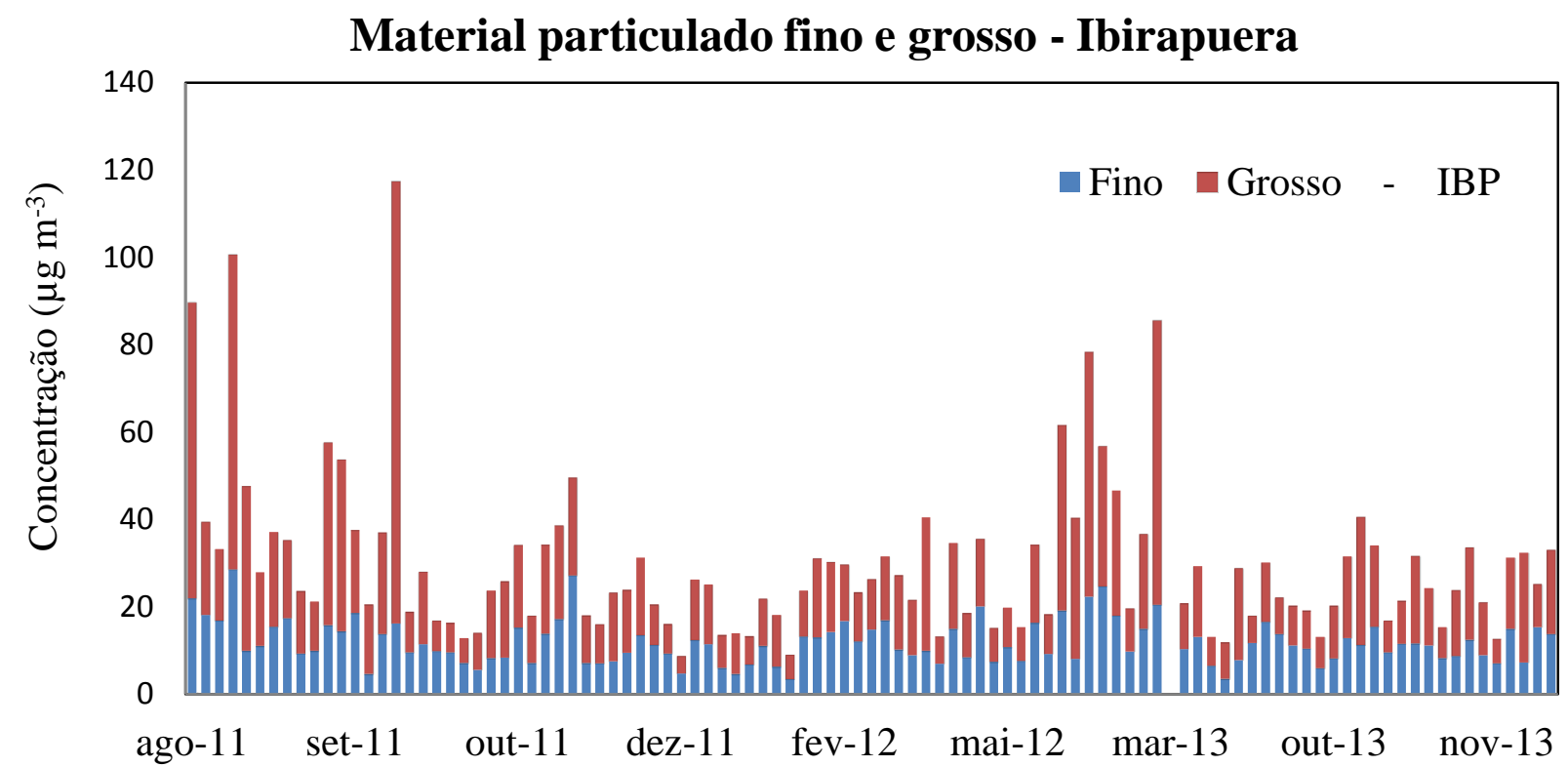

Figura 4-1 Série temporal da concentração em massa do material particulado inalável discriminado nas frações fina e grossa, no Ibirapuera, no período de Agosto de 2011 a Novembro de 2013.

\section{Material particulado fino e grosso - IFUSP}

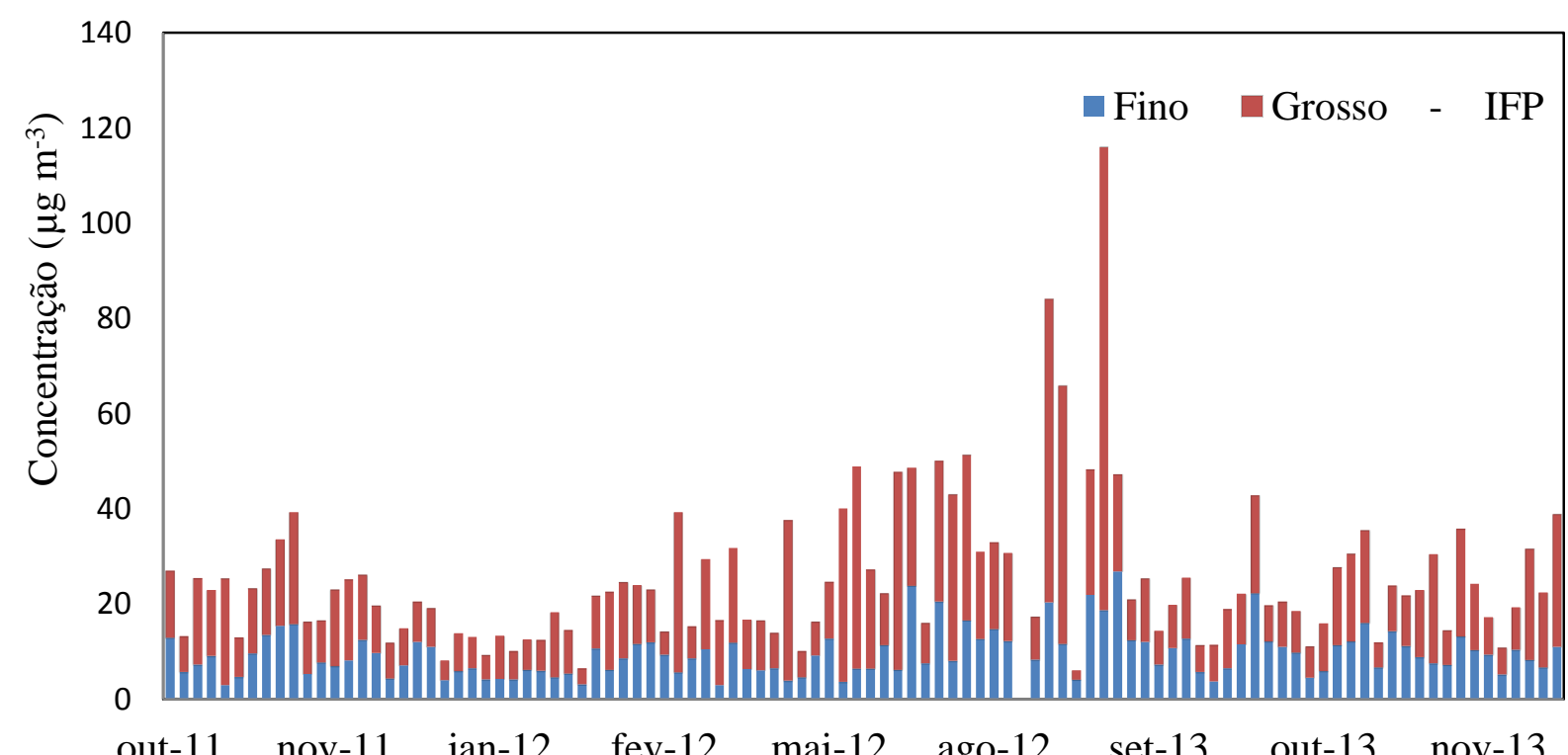

Figura 4-2 Série temporal da concentração em massa do material particulado inalável discriminado nas frações fina e grossa, na estação IFP, no período de Outubro de 2011 a Novembro de 2013. 


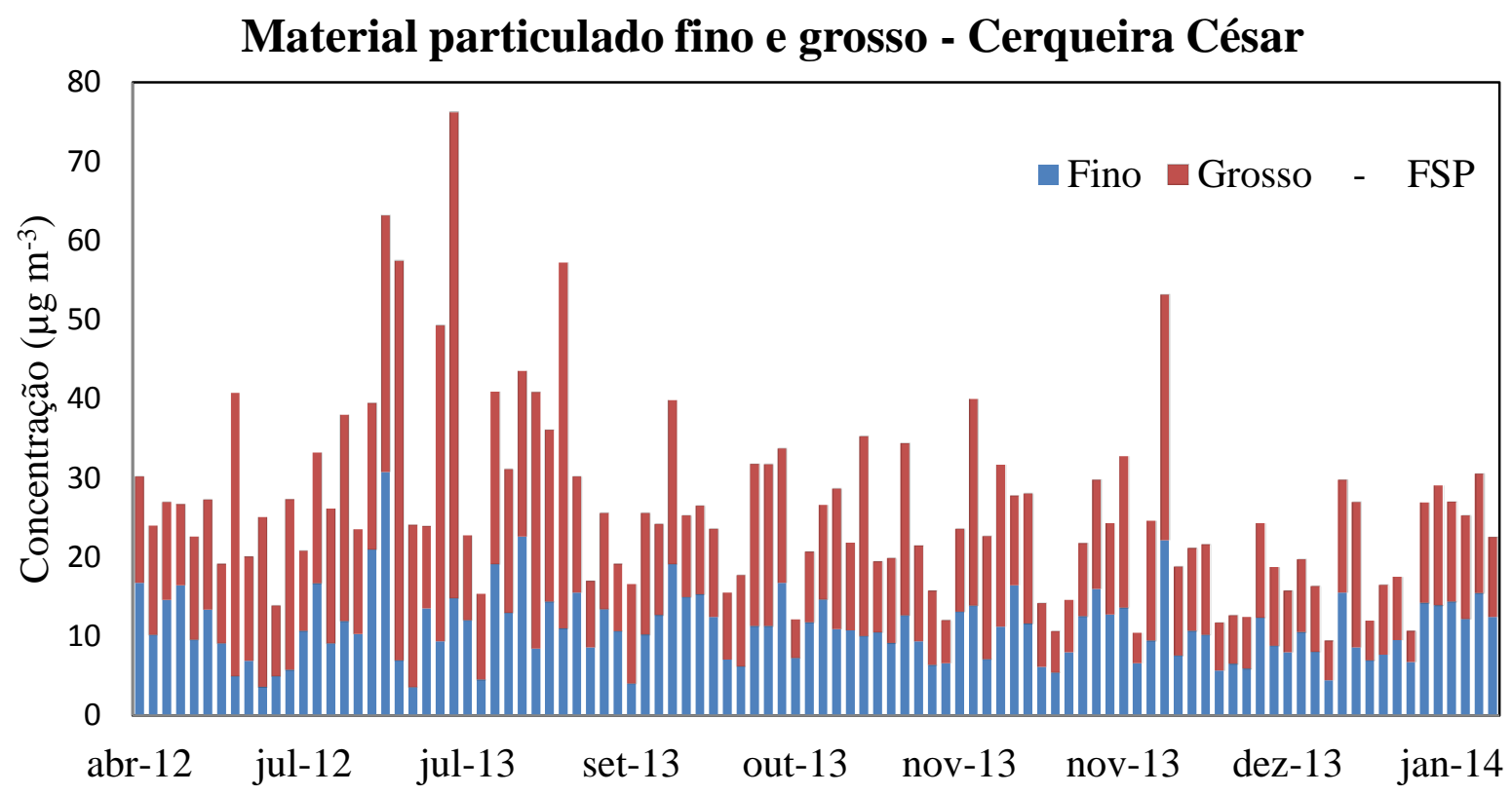

Figura 4-3 Série temporal da concentração em massa do material particulado inalável discriminado nas frações fina e grossa, em Cerqueira César, no período de Abril de 2012 a Janeiro de 2014.

Material particulado inalável - Congonhas

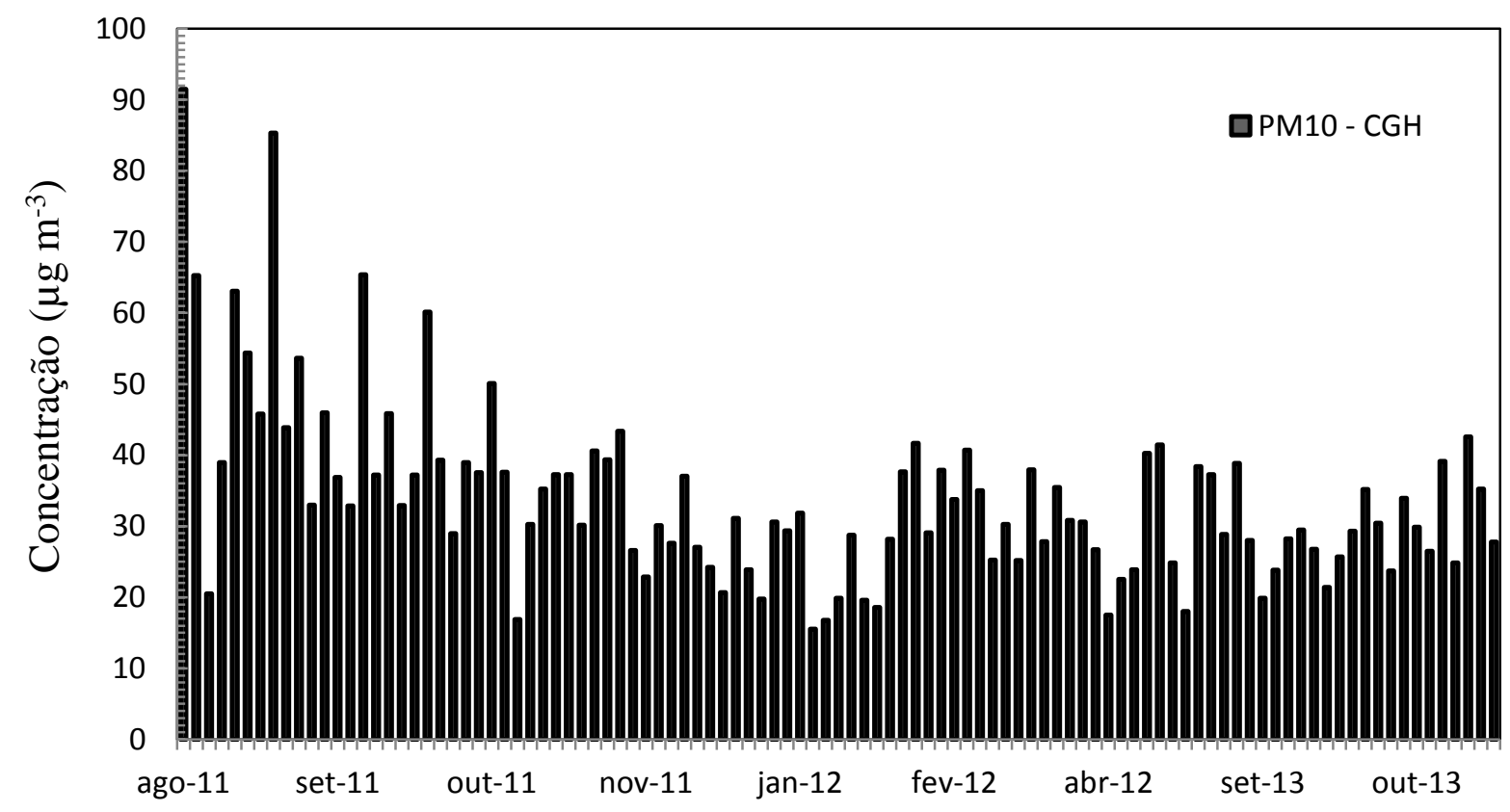

Figura 4-4 Série temporal da concentração em massa do material particulado inalável, dado pela soma das frações fina e grossa, em Congonhas, no período de Agosto de 2011 a Novembro de 2013. 
Observando-se a similaridade observada para as medidas de $\mathrm{PM}_{2.5}$ nas estações amostradoras IFP, FSP e IBP, foi feita a análise conjunta dessas três estações, fornecendo cerca de 300 amostras de $\mathrm{PM}_{2.5}$. Foram considerados então apenas os filtros amostrados no inverno (Maio, Junho, Julho e Agosto) e no verão (Novembro, Dezembro, Janeiro e Fevereiro). Como mostrado na tabela 4-2, as concentrações médias de $\mathrm{PM}_{2.5}$ foram de $9.8 \mu \mathrm{m}^{-3}$, no período de verão, e $13.2 \mu^{-3}$, no caso do inverno. Este resultado mostra um perfil sazonal nas concentrações de material particulado atmosférico, com concentração média $35 \%$ maior para o período de inverno.

\begin{tabular}{ccccc}
\hline \multicolumn{5}{c}{ PM $_{2.5}$ para o conjunto das estações IFP, FSP e IBP $\left(\mu \mathrm{g} \mathrm{m}^{-3}\right)$} \\
\hline & Média & $\boldsymbol{\sigma}$ & Min. & Máx \\
\cline { 2 - 5 } Verão & 9.85 & 4.1 & 3.19 & 27.19 \\
Inverno & 13.2 & 6.3 & 3.58 & 30.74 \\
\hline
\end{tabular}

Tabela 4-2 - Análise descritiva das concentrações de material particulado fino para o conjunto de dados das estações amostradoras IFP, FSP e IBP. São apresentados os resultados para filtros amostrados no inverno (Maio, Junho, Julho e Agosto), no verão (Novembro, Dezembro, Janeiro e Fevereiro), além da série completa. $\sigma$ representa o desvio padrão da média.

\subsection{Validação das medidas de material particulado}

A validação da base dados é essencial para garantir a confiabilidade dos resultados da quantificação de fontes do aerossol atmosférico. Nesse sentido, a proximidade das estações amostradoras do projeto FONTES e das estações fixas da CETESB possibilitou uma comparação entre os resultados. As figuras 4-5 a 4-8 apresentam uma regressão linear entre o PM $_{10}$ medido nas estações de monitoramento da CETESB e os resultados obtidos no LFA-IFUSP por gravimetria. 
Regressão linear entre as medidas da CETESB e do LFA para PM10 na estação amostradora de Congonhas

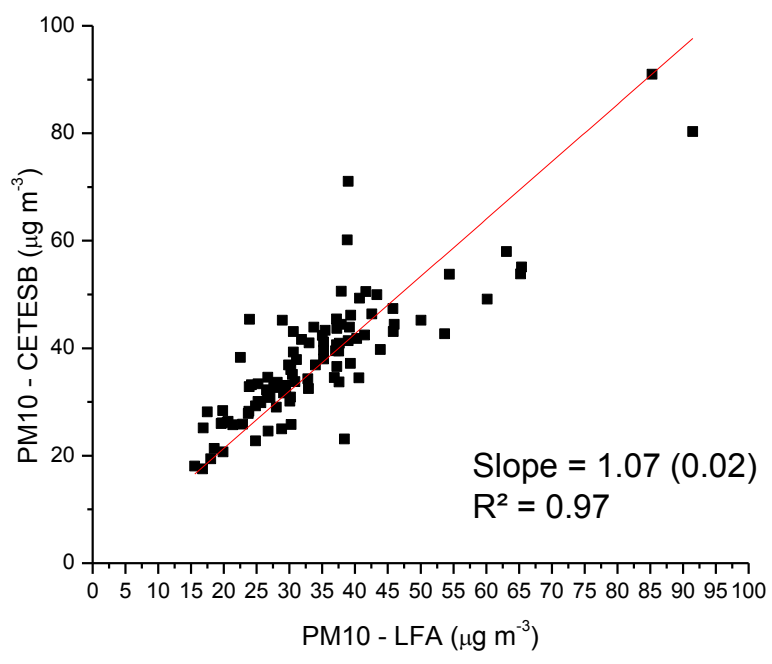

Figura 4-5 - Regressão linear entre as medidas de material particulado PM10 feitas pela CETESB e pelo LFA-IFUSP para a estação amostradora de Congonhas.

\section{Regressão linear entre as medidas da} CETESB e do LFA para PM10 na estação amostradora de Cerqueira César

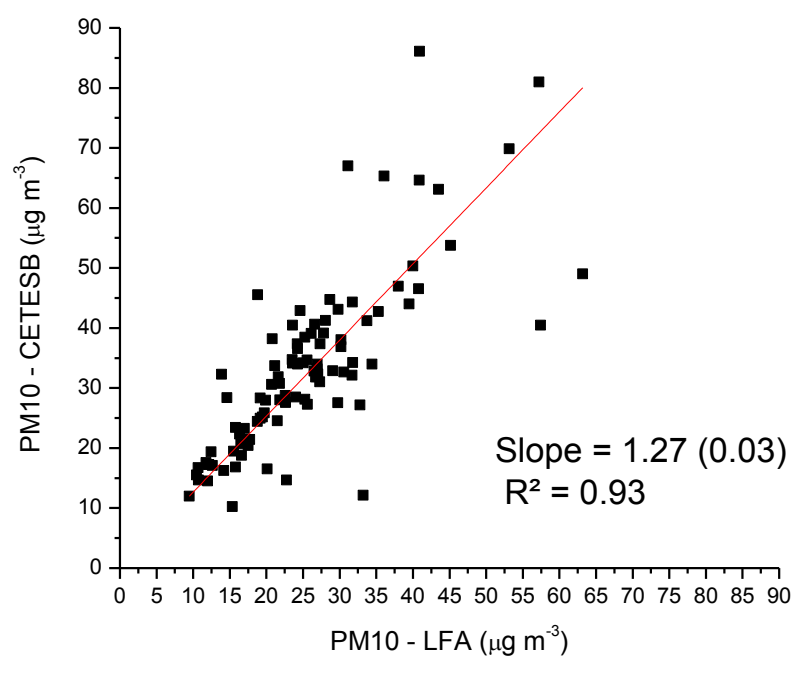

Figura 4-7 - Regressão linear entre as medidas de material particulado PM10 feitas pela CETESB e pelo LFA-IFUSP para a estação amostradora Cerqueira César.
Regressão linear entre as medidas da CETESB e do LFA para PM10 na estação amostradora do Ibirapuera

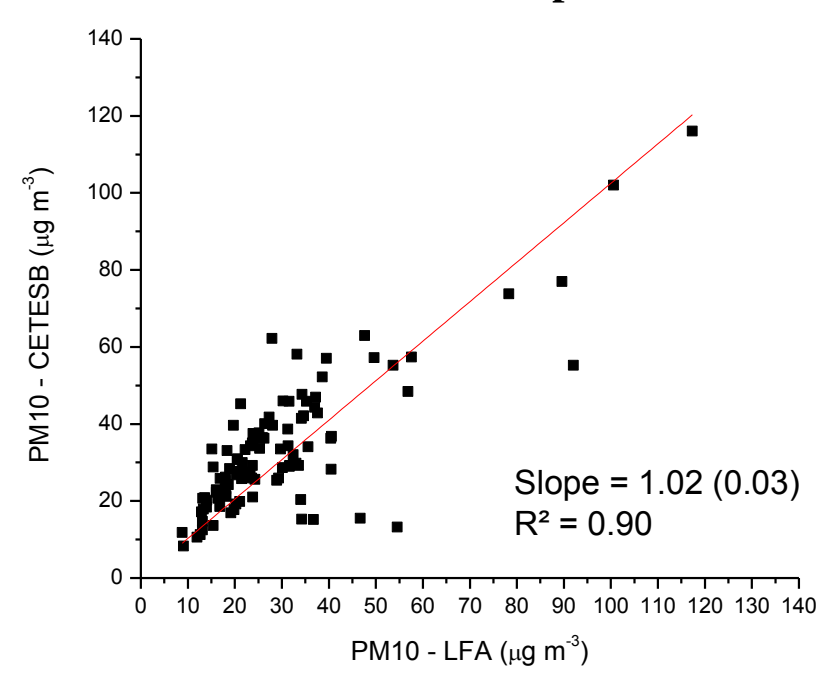

Figura 4-6 - Regressão linear entre as medidas de material particulado PM10 feitas pela CETESB e pelo LFA-IFUSP para a estação amostradora Ibirapuera.

Regressão linear entre as medidas da CETESB e do LFA para PM10 na estação amostradora do IFUSP

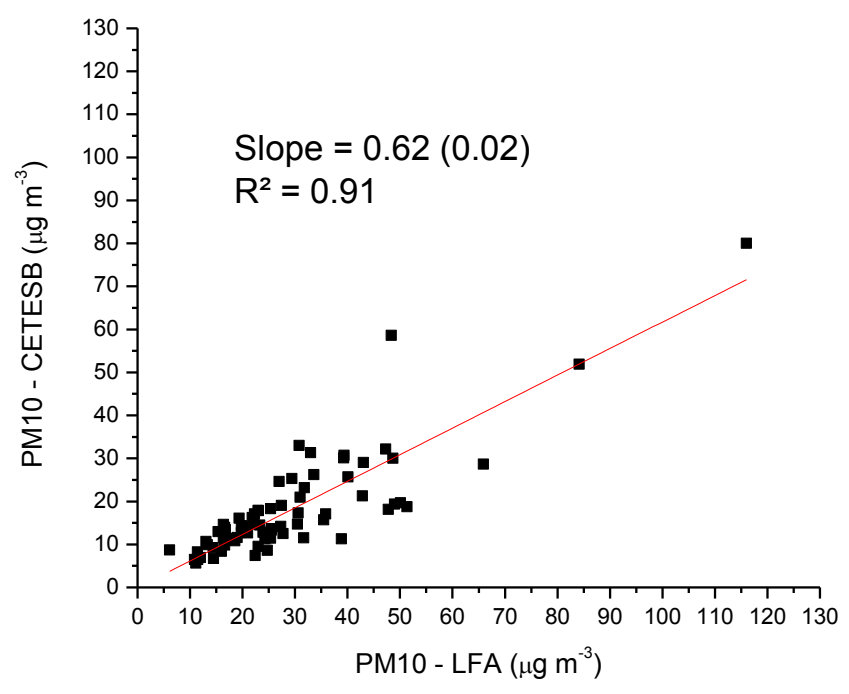

Figura 4-8 - Regressão linear entre as medidas de material particulado PM10 feitas pela CETESB e pelo LFA-IFUSP para a estação amostradora do IFUSP. 
Outro ponto importante nesta comparação é que as medidas realizadas pela CETESB são feitas com a técnica Beta Gauge, onde as concentrações são derivadas a partir da atenuação de raios $\beta$ pelo aerossol coletadas em uma fita, enquanto as medidas feitas no LFA-IFUSP são realizadas por meio de análises gravimétricas reais. Além disso, os dados da CETESB são oriundos de medidas em tempo real, enquanto os filtros do LFA-IFUSP tem amostragem em períodos de 24 a 40 horas. Em vista dos diferentes princípios de operação dos instrumentos e das diferenças entre os locais de realização das medidas, a comparação entre os resultados da CETESB e do LFA-IFUSP pode ser considerada consistente.

\subsection{A composição elementar e iônica do aerossol em São Paulo}

Foram determinadas as concentrações elementares dos filtros Nuclepore nas frações fina e grossa por meio da técnica de fluorescência de raios-X (XRF). Os valores médios medidos nas estações IBP, FSP e IFP são apresentados nas figuras 4-9 e 4-10. Na fração fina são observadas concentrações majoritárias de $\mathrm{S}$, da ordem de $800 \mathrm{ng} \mathrm{m}^{-3}$, e dos elementos $\mathrm{Al}, \mathrm{Si}, \mathrm{K}, \mathrm{Fe}$ e $\mathrm{Na}$, da ordem de $100 \mathrm{ng} \mathrm{m}^{-3}$. Na fração grossa, verifica-se maior impacto das espécies Al, Si, Ca e Fe, em concentrações superiores a $500 \mathrm{ng} \mathrm{m}^{-3}$. Como já discutido anteriormente, nos filtros coletados na estação amostradora de CGH não foi possível discriminar as frações fina e grossa.

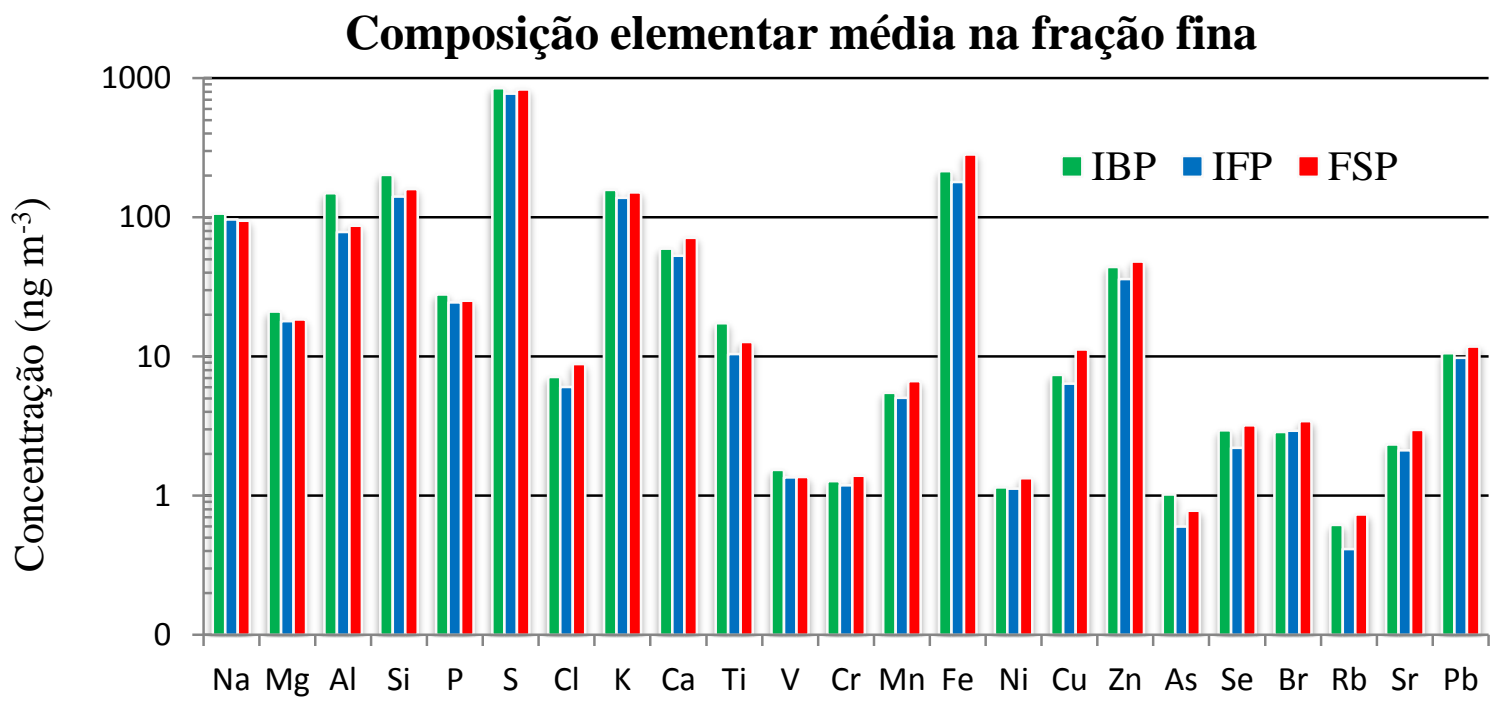

Figura 4-9 Concentrações elementares médias identificadas na moda fina em IBP, IFP e FSP por XRF. Gráfico em escala logarítmica. 


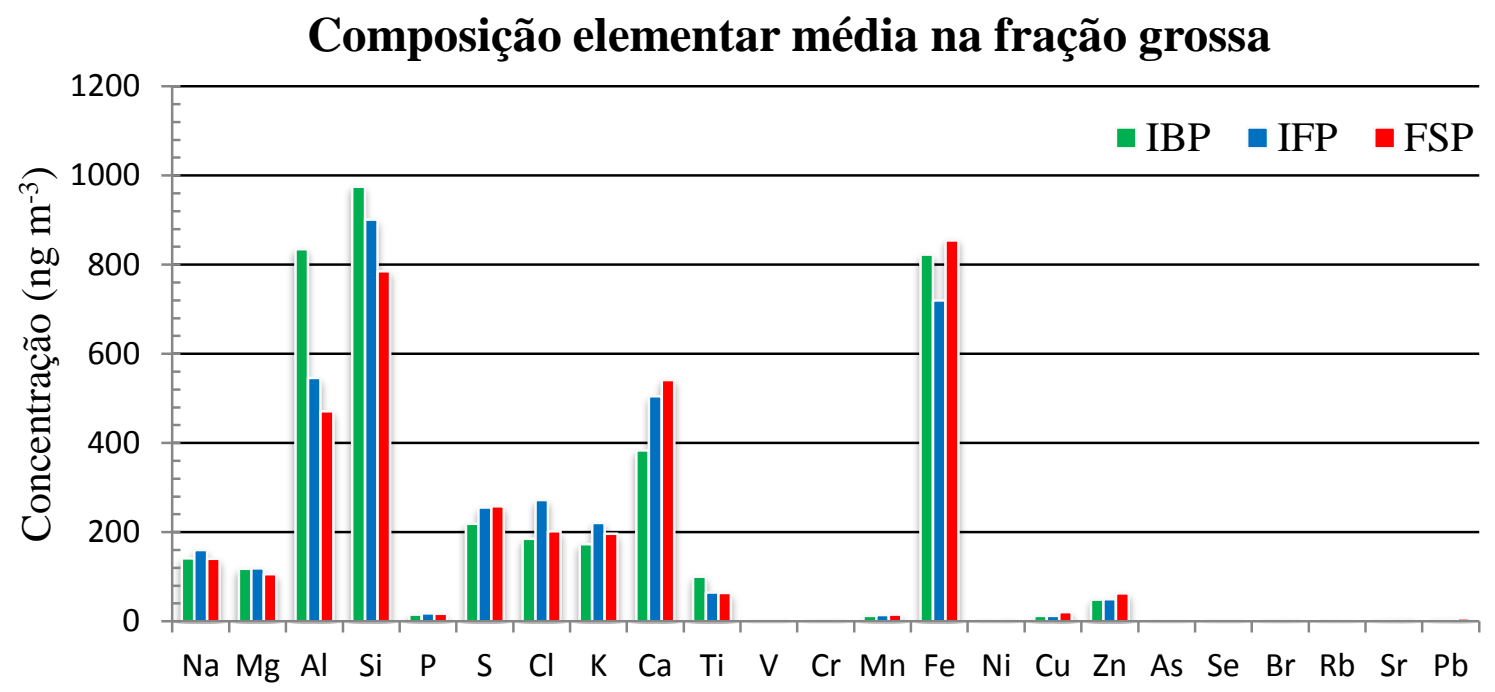

Figura 4-10 Concentrações elementares médias identificadas na moda grossa em IBP, IFP e FSP por XRF. Gráfico em escala logarítmica.

Observamos nas figuras 4-9 e 4-10 uma grande similaridade na concentração elementar do aerossol na moda fina e grossa nas 3 estações com concentrações apresentadas. Isso é fortemente um indicio de mistura homogênea nestas 3 estações para o material particulado, pelo menos em termos de concentrações médias.

A figura 4-11 apresenta as concentrações médias para elementos majoritários (com concentração superior a $\left.100 \mathrm{ng} \mathrm{m}^{-3}\right)$ no particulado inalável $\left(\mathrm{PM}_{10}\right.$, dado pela soma das frações e grossa) para as quatro estações amostradoras. Na figura 4-12 são apresentados esses resultados para elementos em concentrações inferiores a $100 \mathrm{ng} \mathrm{m}^{-3}$ (minoritários).

Observou-se uma similaridade importante na composição elementar do aerossol para as três estações de IBP, IFP e FSP, com diferenças importantes na estação de CGH. As concentrações médias elementares de Si e Al, por exemplo, são notoriamente mais elevadas na estação IBP em relação às demais. No sítio de CGH, por outro lado, verificou-se uma concentração do elemento $\mathrm{Fe}$ cerca de $80 \%$ maior do que nas outras estações. Quanto aos elementos minoritários, verificam-se concentrações mais altas dos elementos $\mathrm{Cu}$ e $\mathrm{Zn}$ nas estações de CGH e FSP, comparadas às outras estações. No caso particular de CGH, a concentração média de $\mathrm{Cu}$ foi cerca de três vezes maior do que nos sítios de IBP e IFP. É possível notar ainda concentrações elementares de V, Cr, Mn e Ni de 30 a $60 \%$ maiores em 
CGH. Na estação FSP, finalmente, verificou-se um impacto maior de $\mathrm{Pb}$, que é difícil de compreender, pois não há emissões industriais de Pb próximo à FSP, e o impacto veicular é similar às demais estações, com exceção à XGH, já analisado.

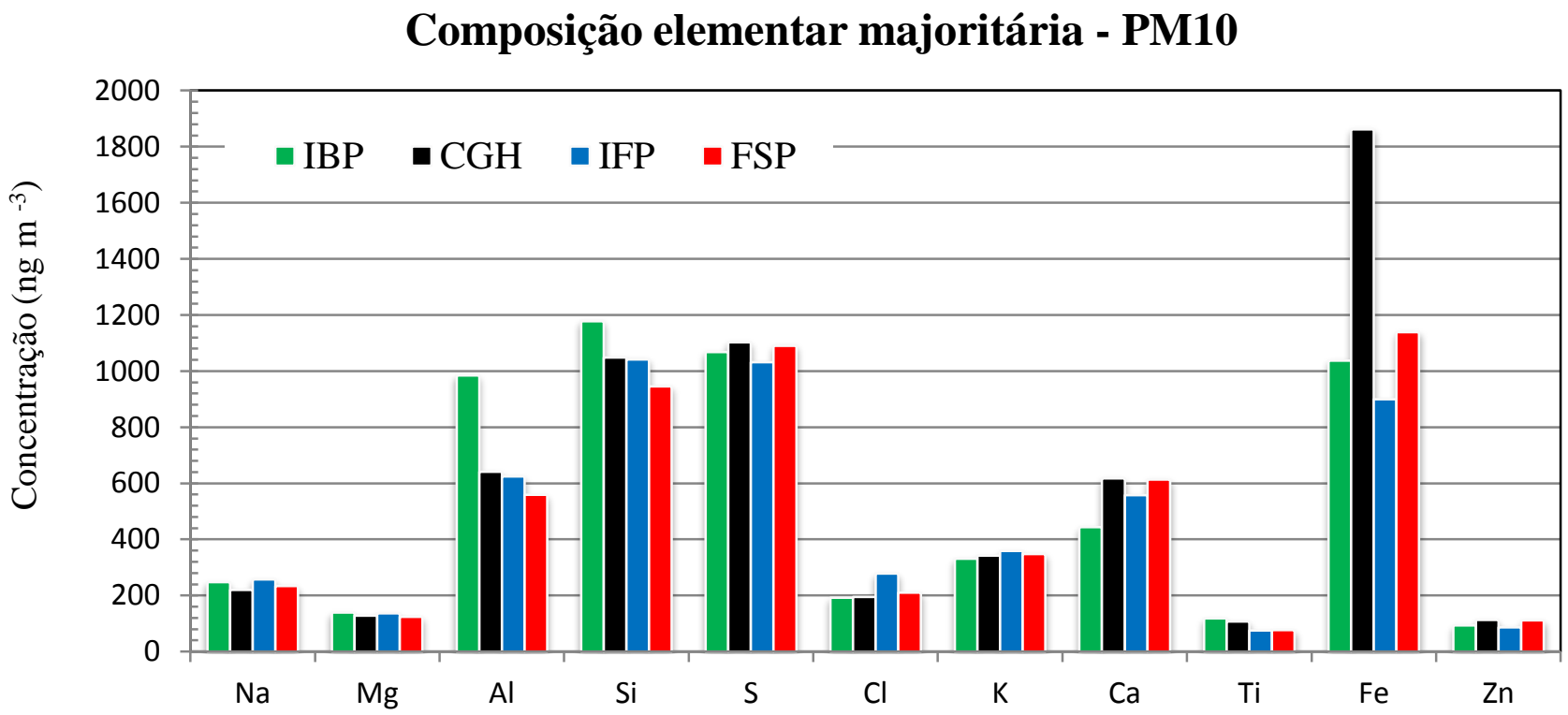

Figura 4-11 Composição elementar média do PM10 para as quatro estações. Elementos com concentração acima de $100 \mathrm{ng} \mathrm{m}^{-3}$.

Composição elementar minoritária - PM10

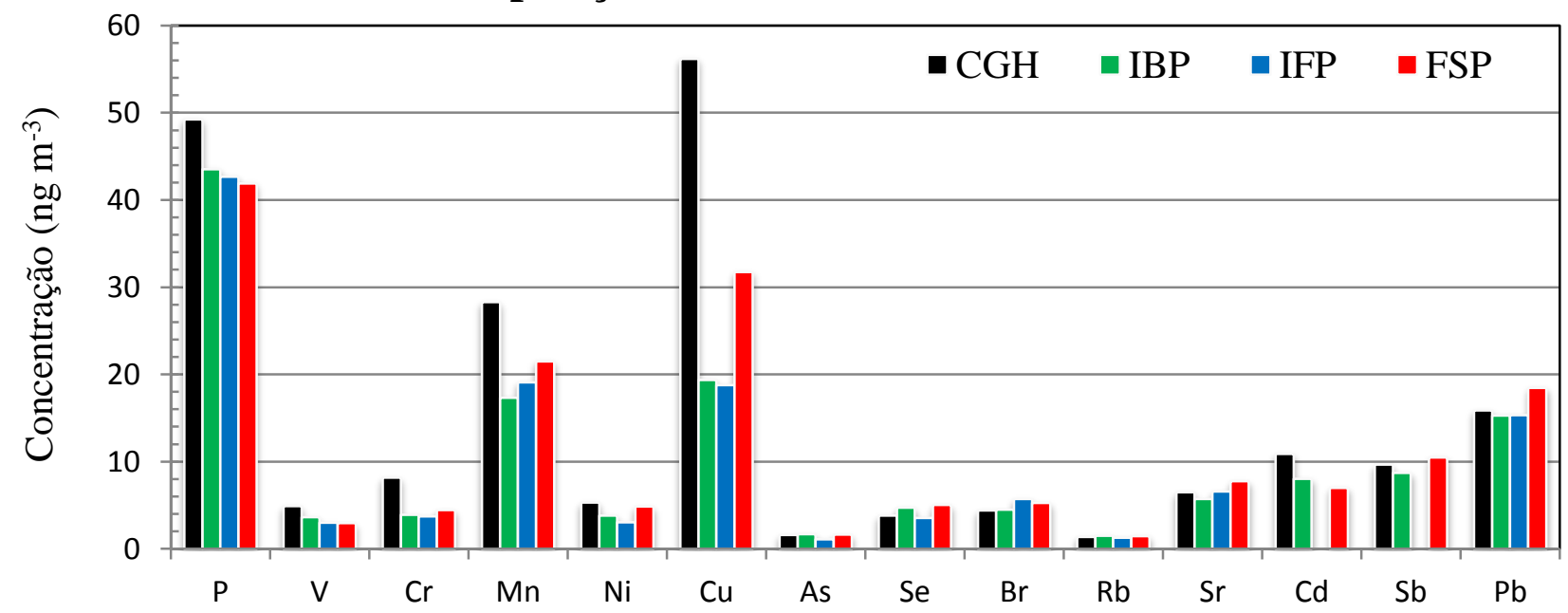

Figura 4-12 Composição elementar média do PM10 para as quatro estações. São listados os elementos traços com concentração abaixo de $100 \mathrm{ng} \mathrm{m}^{-3}$.

A variabilidade da composição elementar é extremamente importante como ferramenta para a identificação de fontes através do uso de modelos receptor, uma vez que esses elementos 
podem ser utilizados como traçadores dos diferentes tipos de emissões. Empregou-se também aos filtros de policarbonato Nuclepore a técnica de cromatografia iônica (IC), determinando-se as concentrações de compostos iônicos. A análise de IC não foi aplicada aos filtros amostrados na estação de CGH.

As figuras 4-13 e 4-14 mostram as concentrações médias da composição iônica do aerossol nas frações fina e grossa, respectivamente. Em todas as estações de amostragem as concentrações de sulfato predominam na fração fina, da ordem de $2,5 \mu \mathrm{g} \mathrm{m}^{-3}$; seguidas de amônia, da ordem de $800 \mathrm{ng} \mathrm{m}^{-3}$. Em geral, verifica-se grande similaridade na composição iônica do aerossol na fração fina. As concentrações de ácidos orgânicos tais como oxalato, formiato e acetato se apresentam com valores relativamente elevados, indicativos de processo de formação de aerossol orgânico secundário na atmosfera de São Paulo.

\section{Composição média na fração fina}

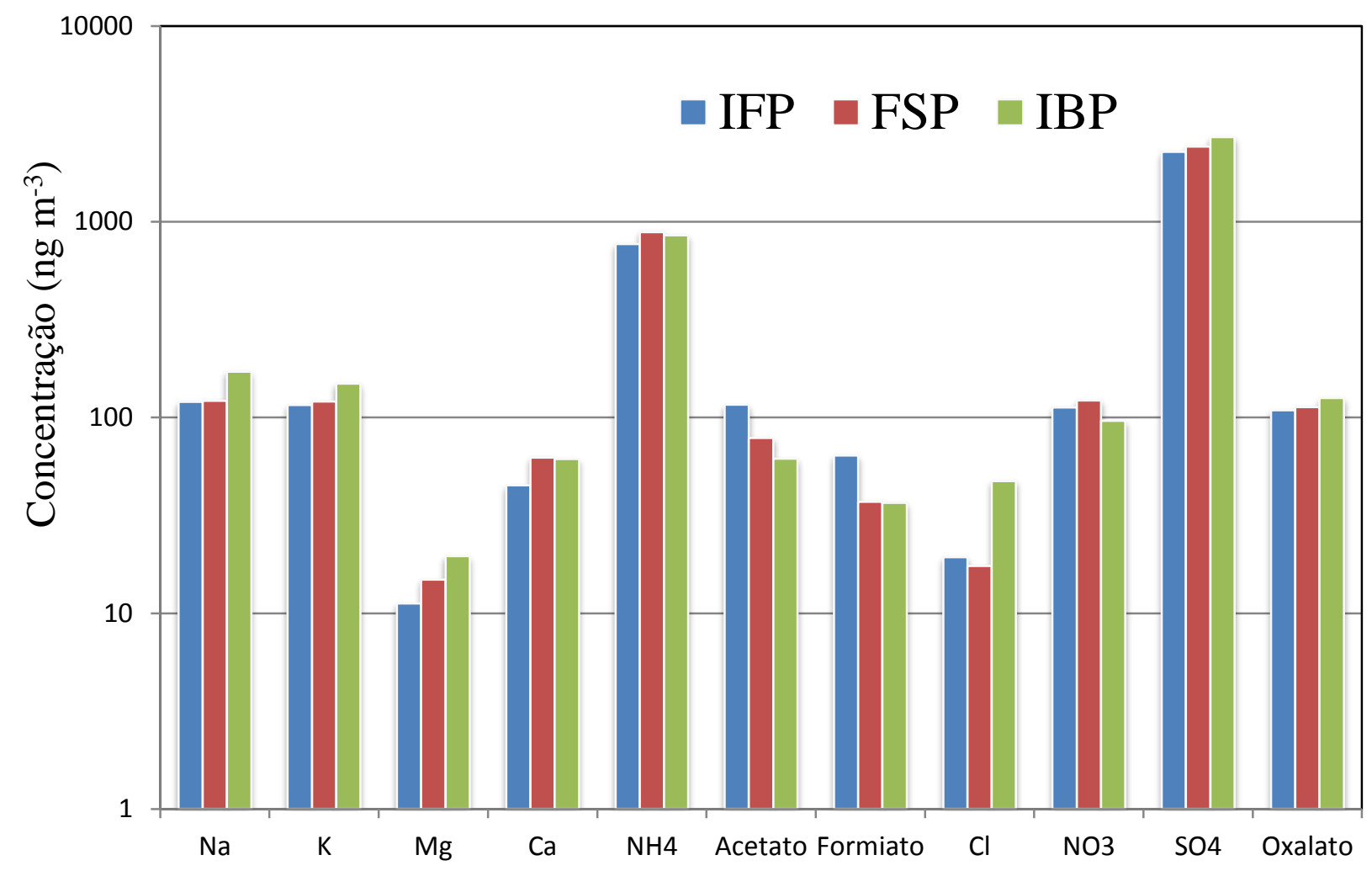

Figura 4-13 Composição iônica média da fração fina para IFP, FSP e IBP determinada por IC. Gráfico de barras em escala logarítmica. 


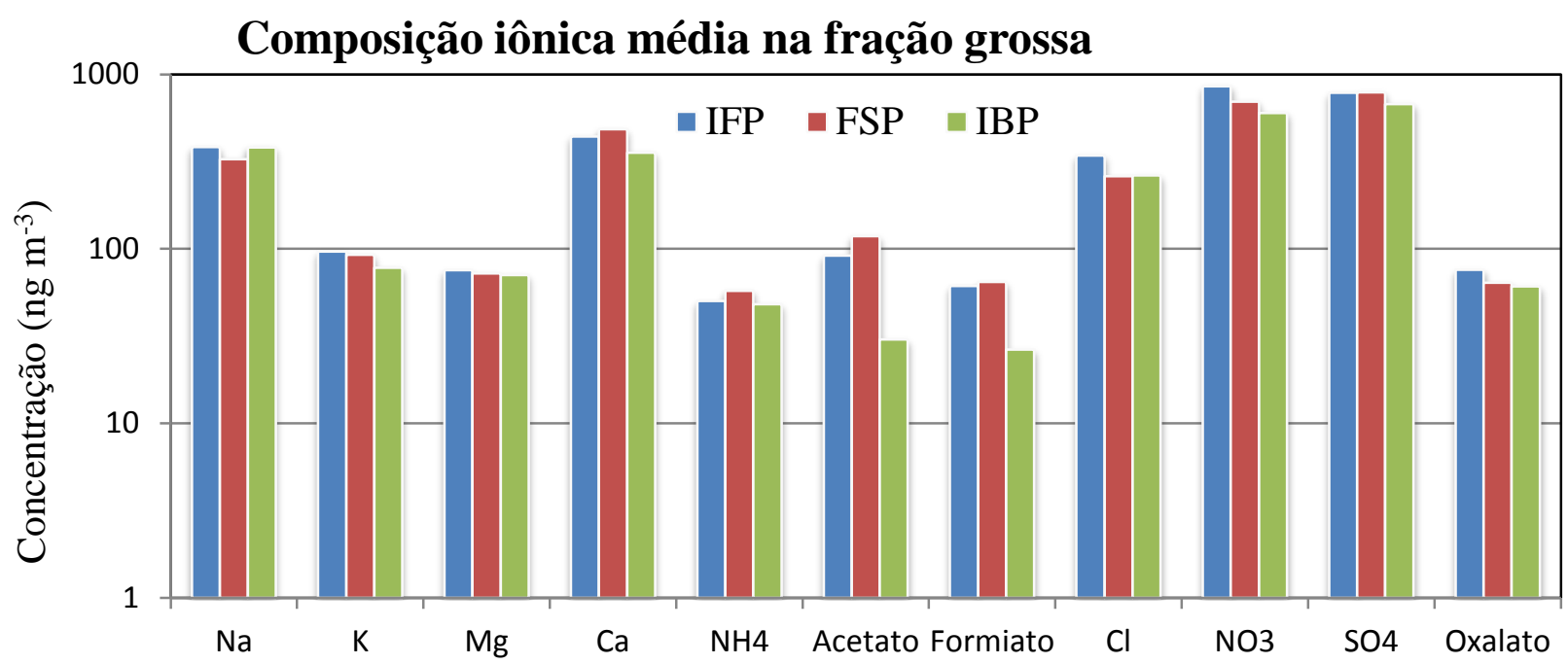

Figura 4-14 Composição iônica média da fração grossa para IFP, FSP e IBP determinada por IC. Gráfico de barras em escala logarítmica.

$\mathrm{Na}$ fração grossa, predominaram as concentrações de sulfato e nitrato, da ordem de 700 $\mathrm{ng} \mathrm{m}^{-3}$, mas, diferentemente da fração fina, há uma importante contribuição de íons Na, Ca e Cl. O sódio e cloro são conhecidos como originários de aerossol marinho. Ao contrário do que se verificou na fração fina, as concentrações de amônia foram menores que $100 \mathrm{ng} \mathrm{m}{ }^{-3}$, assim como os demais compostos iônicos determinados. Para os ácidos orgânicos, acetato e formiato, verificaram-se concentrações menores por um fator 3 na estação IBP.

\subsection{Comparação entre as medidas feitas por Cromatografia Iônica e XRF}

A comparação entre as análises feitas por IC e XRF pode auxiliar na validação da base de dados, pois vários compostos são solúveis em sua totalidade, o que fornece concentrações de IC e XRF similares. Portanto, para elementos totalmente solúveis em água, é esperada boa concordância entre os resultados das duas técnicas, enquanto para elementos que apresentam frações insolúveis significativas, não são esperadas relações lineares entre as medidas por EDXRF e IC. Deve-se salientar também que a técnica de XRF não é ideal para elementos leves (principalmente $\mathrm{Na}, \mathrm{Mg}, \mathrm{Al}, \mathrm{Si}$ ) devido a problemas de auto absorção de raios-X nas partículas de aerossóis, o que não ocorre com a IC (Arana, 2014). 
As figuras 4-15, 4-16 e 4-17 apresentam uma regressão linear entre o ânion sulfato medido por IC e o elemento enxofre medido por XRF nas frações fina e grossa para as estações IBP, IFP e FSP. Os coeficientes de regressão obtidos estiveram entre 2.9 e 3.1, resultado muito consistente visto que a razão $\mathrm{SO}_{4} / \mathrm{S}=3$. A validade das medidas de $\mathrm{S}$ na forma elementar e iônica é de extrema importância para a determinação de fontes visto que este elemento é o componente inorgânico de maior contribuição em concentração para a massa total do $\mathrm{PM}_{2.5}$. A regressão resultando num coeficiente linear igual a 3 indica também que o enxofre presente na atmosfera da RMSP encontra-se majoritariamente na forma de sulfato solúvel.

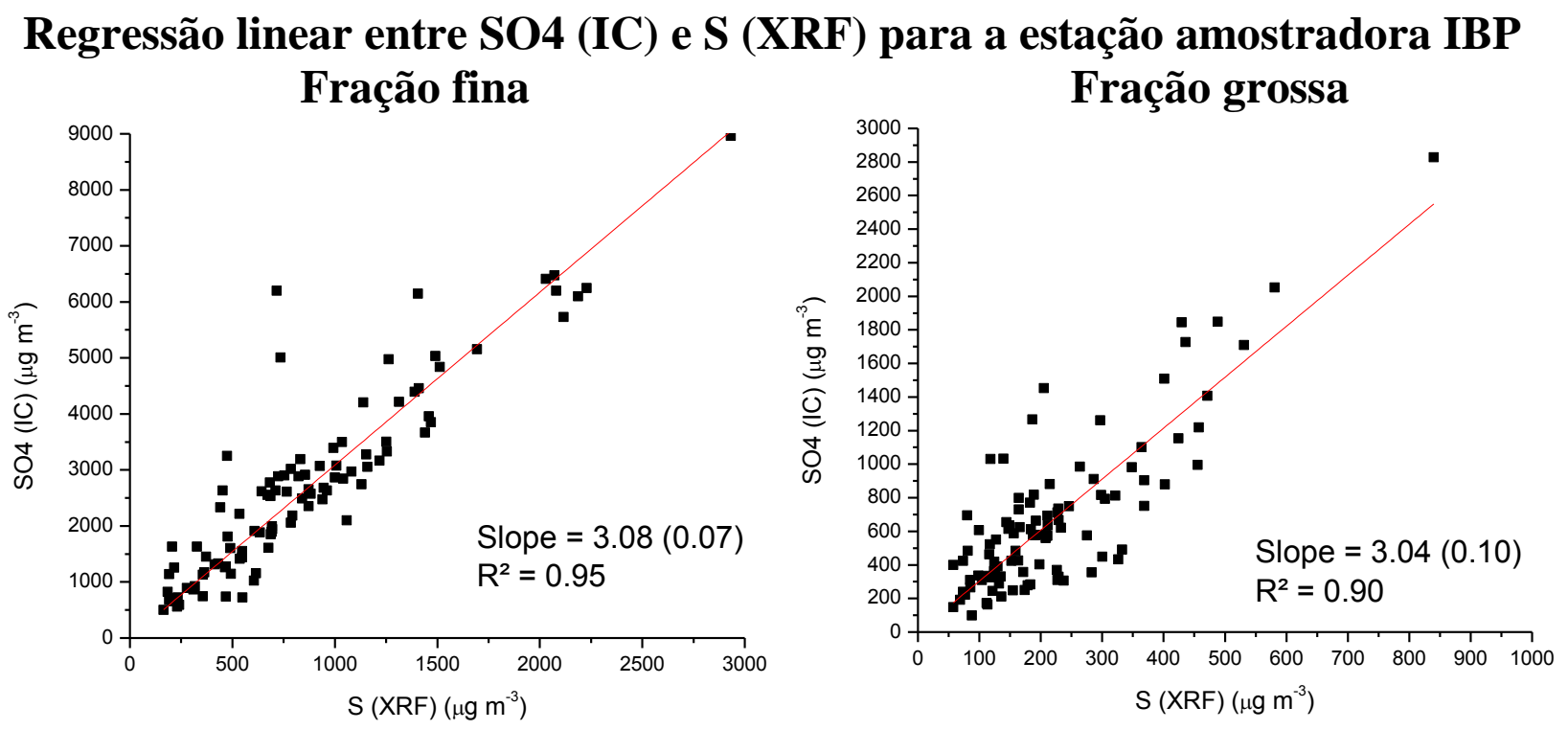

Figura 4-15 - Regressão linear entre os resultados obtidos por XRF (enxofre elementar) e IC (íon sulfato) nas frações fina e grossa para a estação amostradora do Ibirapuera. 


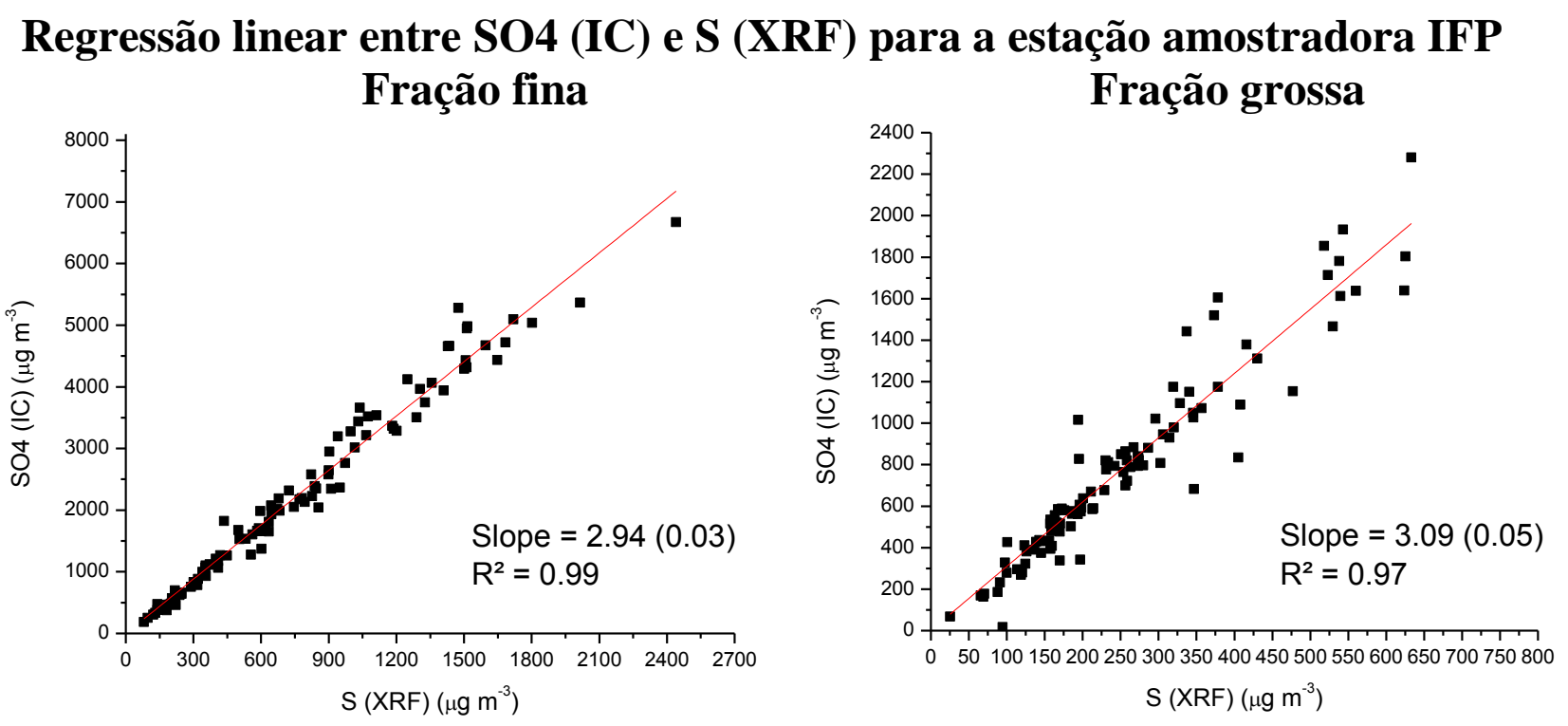

Figura 4-16 - Regressão linear entre os resultados obtidos por XRF (enxofre elementar) e IC (íon sulfato) nas frações fina e grossa para a estação amostradora do IFUSP.

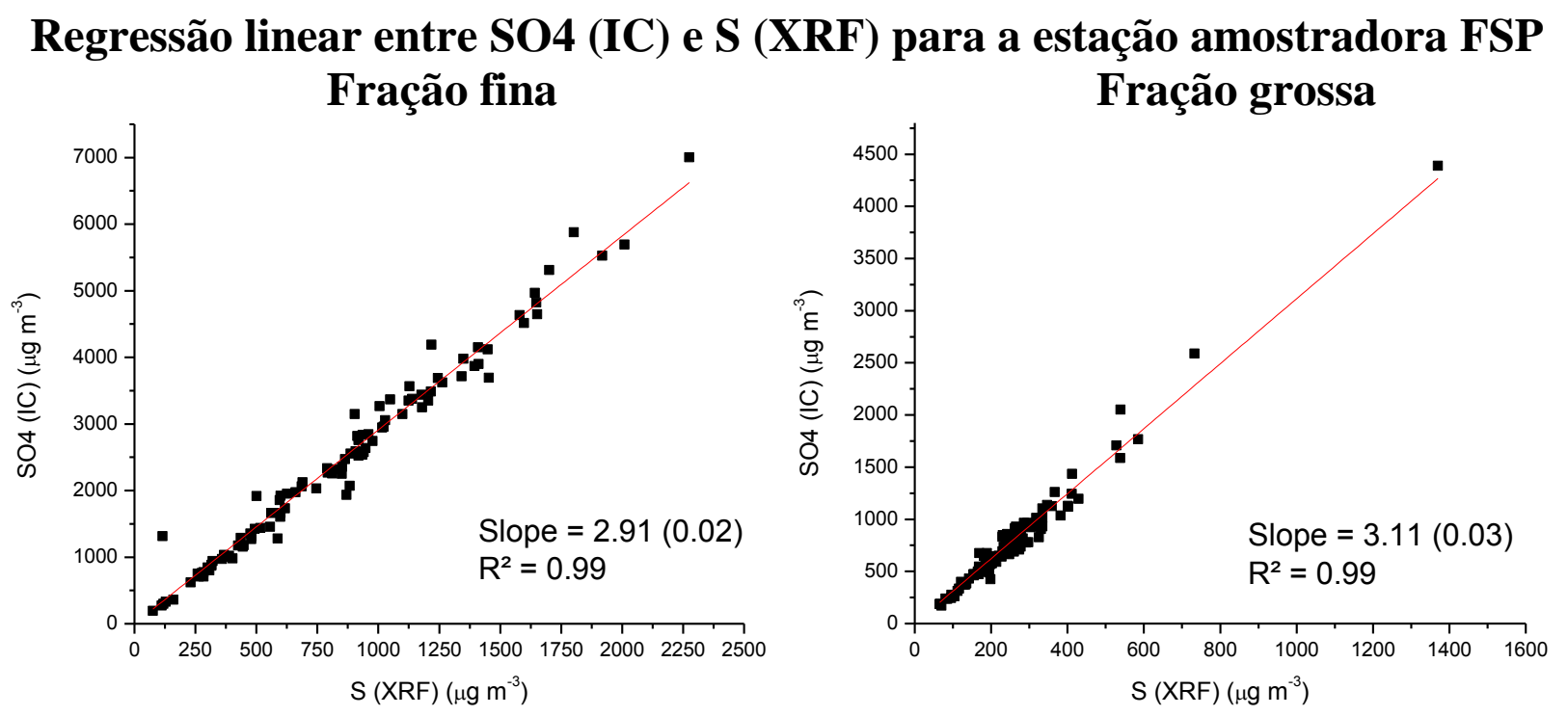

Figura 4-17 - Regressão linear entre os resultados obtidos por XRF (enxofre elementar) e IC (íon sulfato) nas frações fina e grossa para a estação amostradora Cerqueira César.

Na tabela 4-3 apresenta um resumo dos coeficientes de regressão, o erro padrão (SE) e o coeficiente de correlação $\left(\mathrm{R}^{2}\right)$ para os ajustes entre as medidas de IC e XRF para os elementos $\mathrm{S}, \mathrm{Cl}, \mathrm{K}, \mathrm{Ca}$ e $\mathrm{Mg}$, nas frações fina e grossa. Todas as curvas obtidas foram estatisticamente significantes dentro de um nível de confiança de $95 \%$ com coeficientes $\mathrm{R}^{2}$ entre 0.85 e 0.99 , à 
exceção do elemento $\mathrm{Mg}$ e do elemento $\mathrm{Cl}$, especificamente na fração fina. É importante mencionar que estes elementos aparecem frequentemente próximos ao limite de detecção.

\begin{tabular}{cccc|ccc|ccc}
\hline Elemento & \multicolumn{3}{c|}{ Ibirapuera } & \multicolumn{3}{c|}{ IFUSP } & \multicolumn{3}{c}{ Cerqueira César } \\
\hline Fração Fina & coef. & $\mathbf{S E}$ & $\mathbf{R}^{\mathbf{2}}$ & coef. & $\mathbf{S E}$ & $\mathbf{R}^{\mathbf{2}}$ & coef. & $\mathbf{S E}$ & $\mathbf{R}^{\mathbf{2}}$ \\
$\mathrm{Na}$ & 1.48 & 0.06 & 0.85 & 1.26 & 0.02 & 0.98 & 1.28 & 0.02 & 0.96 \\
$\mathrm{Mg}$ & 0.85 & 0.05 & 0.75 & 0.55 & 0.03 & 0.81 & 0.68 & 0.05 & 0.74 \\
$\mathrm{SO}_{4}$ & 3.09 & 0.07 & 0.95 & 2.94 & 0.03 & 0.99 & 2.91 & 0.02 & 0.99 \\
$\mathrm{Cl}$ & 5.86 & 0.60 & 0.48 & 2.34 & 0.16 & 0.69 & 1.36 & 0.13 & 0.59 \\
$\mathrm{~K}$ & 0.90 & 0.03 & 0.92 & 0.86 & 0.01 & 0.99 & 0.82 & 0.01 & 0.98 \\
$\mathrm{Ca}$ & 0.92 & 0.03 & 0.91 & 0.86 & 0.01 & 0.98 & 0.86 & 0.01 & 0.98 \\
& & & & & & & & & \\
Fração Grossa & Coef. & $\mathbf{S E}$ & $\mathbf{R}^{\mathbf{2}}$ & $\mathbf{c o e f .}$ & $\mathbf{S E}$ & $\mathbf{R}^{\mathbf{2}}$ & $\mathbf{c o e f}$ & $\mathbf{S E}$ & $\mathbf{R}^{\mathbf{2}}$ \\
$\mathrm{Na}$ & 2.59 & 0.09 & 0.90 & 2.52 & 0.05 & 0.96 & 2.60 & 0.06 & 0.95 \\
$\mathrm{Mg}$ & 0.52 & 0.03 & 0.74 & 0.55 & 0.03 & 0.82 & 0.64 & 0.02 & 0.88 \\
$\mathrm{SO}_{4}$ & 3.04 & 0.10 & 0.90 & 3.09 & 0.05 & 0.98 & 3.11 & 0.03 & 0.99 \\
$\mathrm{Cl}$ & 1.42 & 0.04 & 0.92 & 1.28 & 0.01 & 0.99 & 1.34 & 0.01 & 0.99 \\
$\mathrm{~K}$ & 0.42 & 0.02 & 0.86 & 0.48 & 0.01 & 0.96 & 0.51 & 0.01 & 0.95 \\
$\mathrm{Ca}$ & 0.88 & 0.03 & 0.91 & 0.85 & 0.01 & 0.99 & 0.88 & 0.01 & 0.99 \\
\hline
\end{tabular}

. Tabela 43 - Coeficientes de regressão linear, erro padrão associado (SE ou Standard Error) e coeficientes de correlação $\left(\mathrm{R}^{2}\right)$ obtidos a partir do ajuste entre as medidas por IC e XRF para as estações amostradoras Ibirapuera, IFUSP e Cerqueira César nas frações fina e grossa. Coeficientes de regressão menores que a unidade indicam concentrações medidas por XRF maiores que as medidas por IC.

Observa-se, para o elemento $\mathrm{Na}$, coeficientes de regressão entre 1.26 e 1.48 (para a fração fina), e da ordem de 2.5 (na fração grossa), confirmando o efeito de auto absorção de raios-X nas partículas, sobretudo na fração grossa. Portanto, pode-se concluir que as medidas de $\mathrm{Na}$ obtidas por XRF são subestimadas. Para o elemento $\mathrm{Mg}$, por outro lado, observa-se que os coeficientes da regressão estão entre 0.52 e 0.85 , indicando valores de concentração menores para medidas de IC em relação à técnica de XRF. Tal resultado deve-se ao fato de que o Mg não é totalmente solúvel em água e mostra que a parte insolúvel é significativa. Similarmente, o ajuste obtido para os elementos $\mathrm{Ca}$ e $\mathrm{K}$ mostrou coeficientes de regressão menores que a unidade. 


\subsection{A análise de Black Carbon Equivalente (EBC)}

Empregou-se a técnica de refletância óptica para a determinação do conteúdo de black carbon equivalente (EBC) nos filtros Nuclepore nas frações fina e grossa do material particulado. A tabela 4-4 apresenta as concentrações médias de EBC medidas nas quatro estações amostradoras. Como discutido nas seções anteriores, no caso particular de CGH, não foi possível discriminar a fração fina da fração grossa.

\begin{tabular}{ccccccccccc}
\hline & \multicolumn{3}{c}{$\begin{array}{c}\text { EBC na fração fina } \\
\left(\mu \mathrm{g} \mathrm{m}^{-3}\right)\end{array}$} & & \multicolumn{3}{c}{$\begin{array}{c}\text { EBC na fração grossa } \\
\left(\mu \mathrm{g} \mathrm{m}^{-3}\right)\end{array}$} & $\begin{array}{c}\text { EBC }_{\text {total }} \\
\left(\mu \mathrm{g} \mathrm{m}^{-3}\right)\end{array}$ & \\
\cline { 2 - 9 } & Média & $\boldsymbol{\sigma}$ & Máx. & Min & Média & $\boldsymbol{\sigma}$ & Máx. & Min & Média & N \\
\hline IBP & 2.39 & 1.11 & 6.20 & 0.56 & 0.37 & 0.36 & 1.95 & 0.11 & 2.76 & 100 \\
IFP & 2.21 & 1.30 & 7.50 & 0.72 & 0.41 & 0.49 & 3.38 & 0.06 & 2.61 & 101 \\
FSP & 2.65 & 1.24 & 7.03 & 0.80 & 0.42 & 0.36 & 1.82 & 0.08 & 3.07 & 100 \\
CGH & $*$ & $*$ & $*$ & $*$ & $*$ & $*$ & $*$ & $*$ & 11.96 & 103 \\
\hline
\end{tabular}

Tabela 4-3 - Análise descritiva das concentrações equivalente black carbon nas frações fina e grossa para as estações amostradoras IFP, FSP, IBP e CGH, onde $\sigma$ representa o desvio padrão da média e $\mathrm{N}$ o número de casos medidos. $\mathrm{O}$ material particulado inalável $\left(\mathrm{PM}_{10}\right)$ é dado pela soma das frações fina e grossa. ${ }^{*} \mathrm{Na}$ estação amostradora de CGH não foi possível discriminar as frações fina e grossa.

A concentração média de EBC foi bastante semelhante nas estações IFP, FSP e IBP, com valores na faixa entre 2.2 e $2.7 \mu \mathrm{g} \mathrm{m}^{-3}$ na fração fina, e de 0.37 a $0.42 \mu \mathrm{g} \mathrm{m}^{-3}$ na fração grossa. Observa-se, portanto, que o EBC representa fração significativa do material particulado na fração fina (constituindo de 20 a $25 \%$ da massa do PM $_{2.5}$ nas estações IBP, IFP e FSP), mas contribui apenas com 2 ou 3\% da massa na fração grossa. Na estação amostradora de Congonhas a concentração média de EBC total foi de $12.0 \mu \mathrm{g} \mathrm{m}^{-3}$, enquanto a média dos demais sítios é $2.6 \mu \mathrm{g} \mathrm{m}^{-3}$, representando cerca de $45 \%$ do $\mathrm{PM}_{10}$. Este fato reforça o altíssimo impacto de emissões de veículos a diesel em CGH, o que prejudicou a separação entre o particulado fino e grosso.

Nas figuras 4-18, 4-19 e 4-20 são apresentadas as séries temporais da concentração em massa de EBC nas modas fina e grossa para as estações IBP, IFP e FSP, respectivamente. Nos 
três casos o EBC aparece majoritariamente na fração fina, correspondendo a 87\% do EBC total (soma das frações fina e grossa). Observamos uma alta variabilidade temporal, indicando um impacto de emissões a diesel variável no tempo.

\section{Black Carbon Equivalente - Ibirapuera}

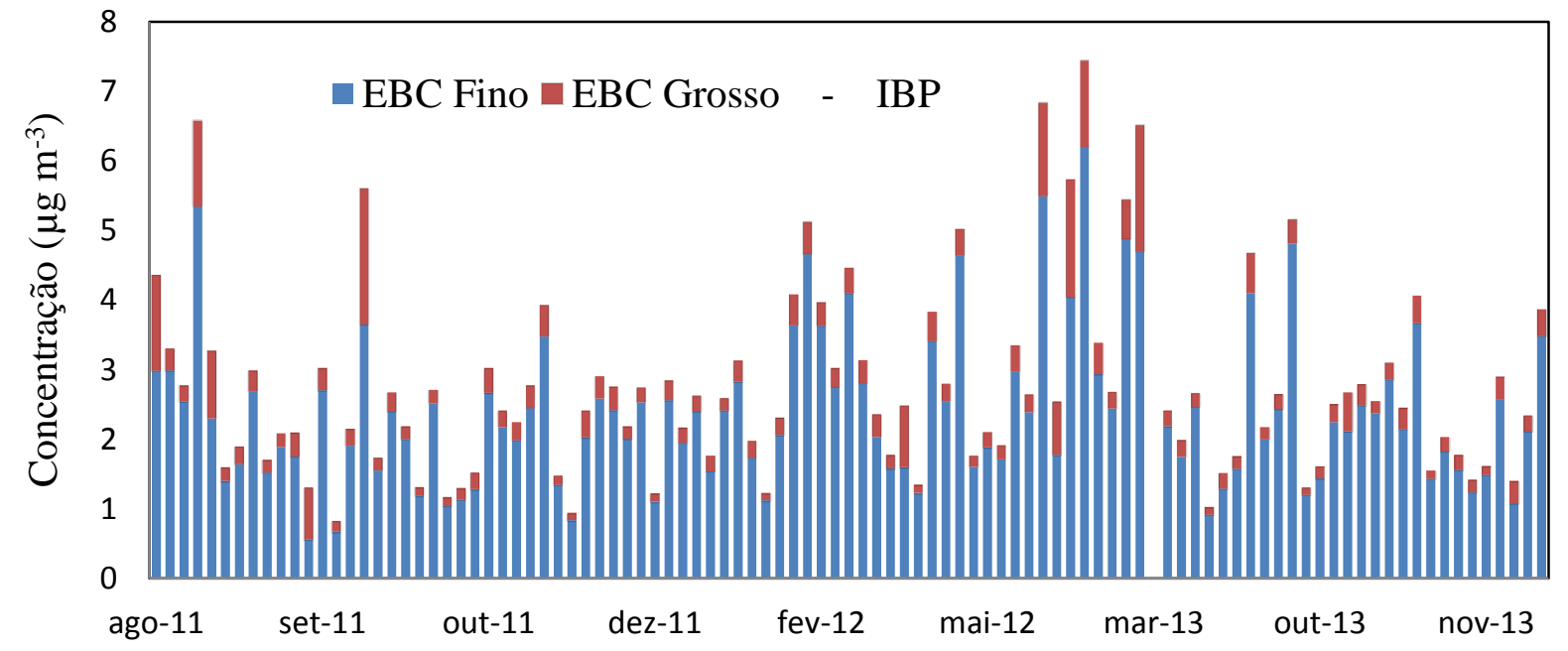

Figura 4-18 Série temporal da concentração em massa de black carbon equivalente discriminado nas frações fina e grossa, na estação amostradora do Ibirapuera, no período de agosto de 2011 a novembro de 2013.

Black Carbon Equivalente - IFUSP

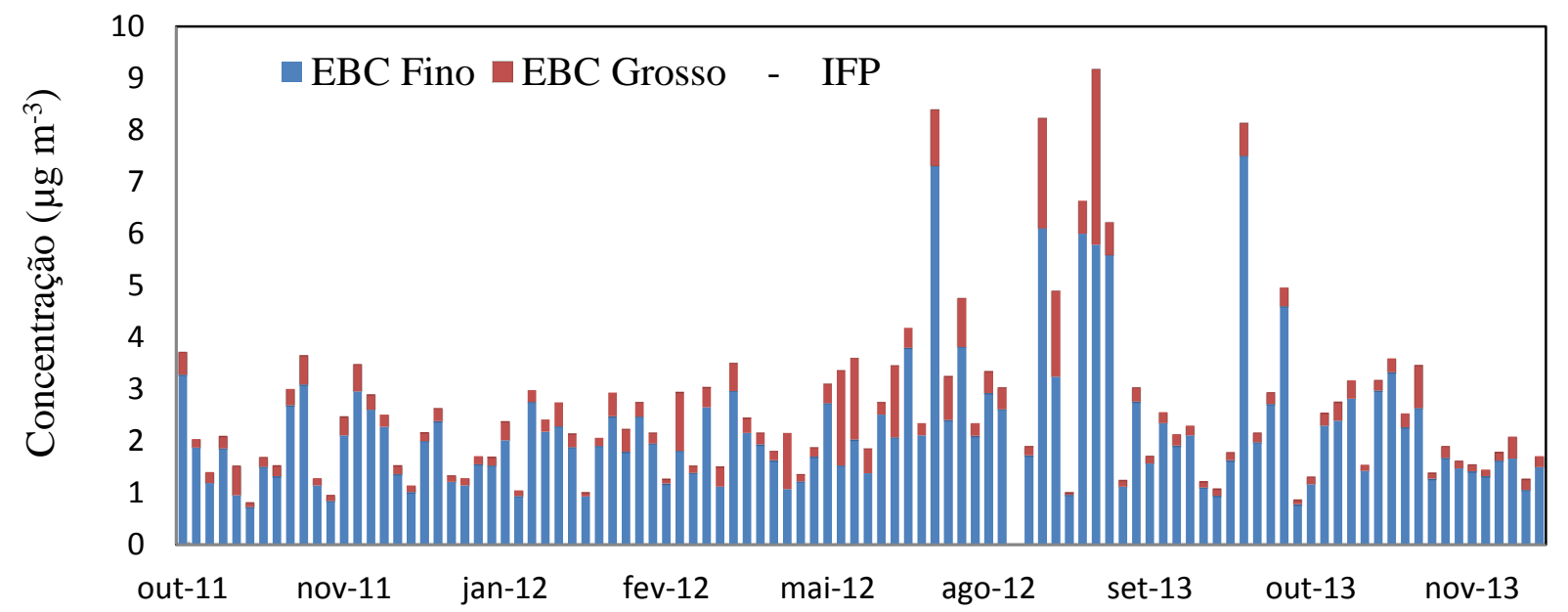

Figura 4-19 Série temporal da concentração em massa de black carbon equivalente discriminado nas frações fina e grossa, na estação amostradora do IFUSP, no período de outubro de 2011 a novembro de 2013. 


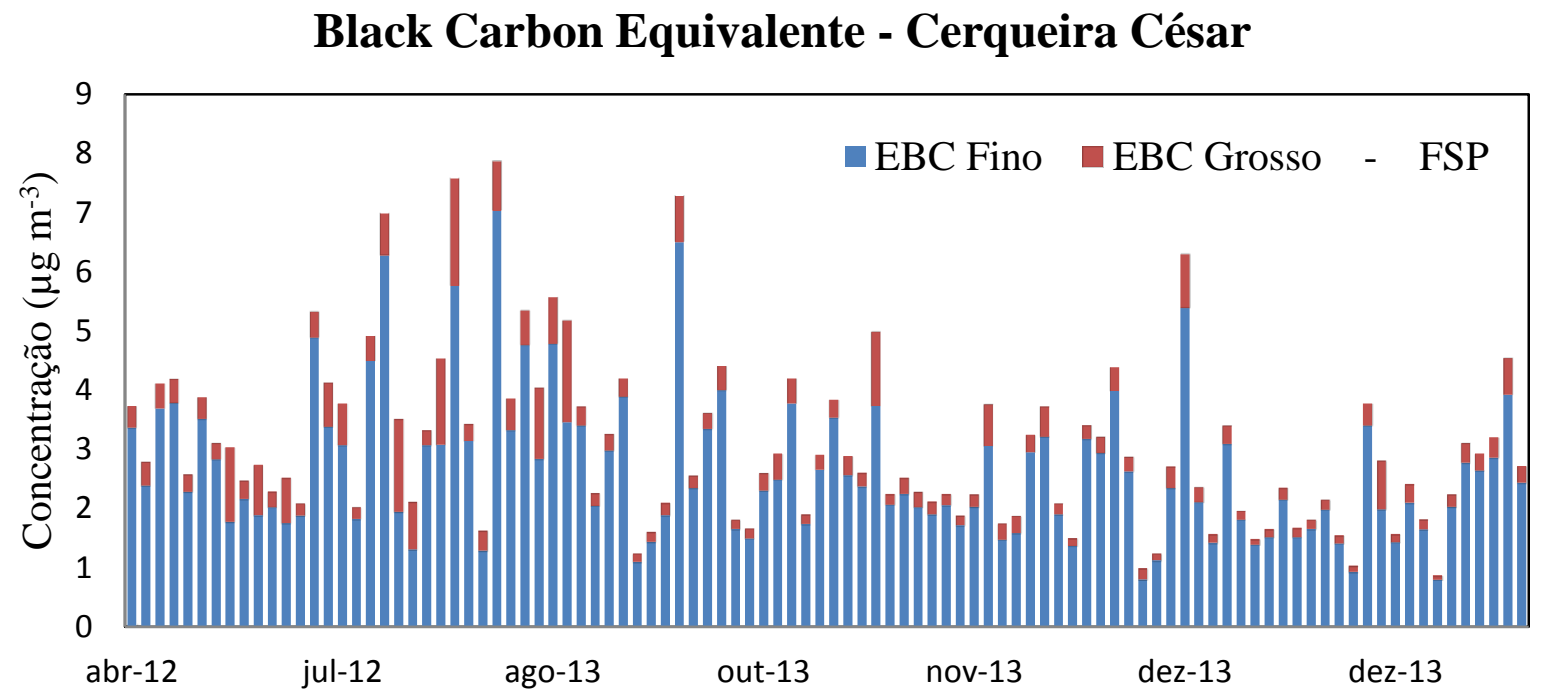

Figura 4-20 Série temporal da concentração em massa de black carbon equivalente discriminado nas frações fina e grossa, na estação amostradora de Cerqueira César, no período de abril de 2012 a janeiro de 2014.

Novamente foram analisadas conjuntamente as cerca de 300 amostras das estações IFP, FSP e IBP, conjuntamente. No período de inverno (Maio, Junho, Julho e Agosto) a concentração média foi de $3.2 \mu \mathrm{m}^{-3}$, enquanto no verão (Novembro, Dezembro, Janeiro e Fevereiro) este valor foi igual a $2.1 \mu^{-3}$. Novamente verifica-se um perfil sazonal, com concentrações mais elevadas em cerca de 50\% no período de inverno. Estes resultados são mostrados na tabela 4-5.

\begin{tabular}{ccccc}
\hline \multicolumn{5}{c}{ EBC (moda fina) para o conjunto das estações IFP, FSP e IBP $\left(\mu \mathrm{g} \mathrm{m}^{-3}\right)$} \\
\hline & Média & $\boldsymbol{\sigma}$ & Min. & Máx \\
\cline { 2 - 5 } Verão & 2.09 & 0.87 & 0.72 & 5.39 \\
Inverno & 3.21 & 1.55 & 0.96 & 7.30 \\
\hline
\end{tabular}

Tabela 4-4 - Análise descritiva das concentrações de black carbon equivalente na fração fina para o conjunto de dados das estações amostradoras IFP, FSP e IBP. São apresentados os resultados para filtros amostrados no inverno (Maio, Junho, Julho e Agosto), no verão (Novembro, Dezembro, Janeiro e Fevereiro), além da série completa. $\sigma$ representa o desvio padrão da média. 


\subsection{Conteúdo carbonáceo no aerossol de São Paulo: Carbono orgânico e elementar}

As frações carbonáceas do aerossol atmosférico foram determinadas a partir da análise termo-óptica do material coletado nos filtros de quartzo, permitindo uma quantificação do carbono nas formas orgânica (OC) e elementar (EC) na fração de $\mathrm{PM}_{2.5}$. A concentração total de carbono (TC) nos filtros é dada pela soma das frações de OC e EC. As figuras 4-21 a 4-24 apresentam as séries temporais da concentração em massa de OC e EC na fração fina do aerossol nas estações IBP, IFP, FSP e CGH, respectivamente.

Na tabela 4-6 são apresentadas as concentrações médias de OC e EC, bem como os desvios padrão associados. Nas estações IBP, IFP e FSP foram observadas concentrações de OC muito próximas, variando entre 3.5 e $3.7 \mu \mathrm{g} \mathrm{m}^{-3}$. Em CGH, por outro lado, a concentração média de OC foi aproximadamente $80 \%$ maior que a média das outras estações. No que diz respeito ao EC, o impacto nas estações IBP, FSP e IFP não mostrou a mesma homogeneidade, sendo mais acentuado em FSP $\left(2.35 \mu \mathrm{g} \mathrm{m}^{-3}\right)$ e menor no IBP $\left(1.83 \mu \mathrm{g} \mathrm{m}^{-3}\right)$. Novamente, CGH apresentou as concentrações mais elevadas, sendo que a média neste sítio foi de $7.84 \mu \mathrm{g} \mathrm{m}^{-3}$. As altas concentrações de $\mathrm{OC}$ e EC em CGH, em comparação aos demais sites, são consistentes com o fato de esta ser a estação de maior impacto veicular. As concentrações de OC e EC em Congonhas são cerca de $100 \%$ superiores às das demais 3 estações.

\begin{tabular}{|c|c|c|c|c|c|c|c|c|c|c|c|}
\hline & \multicolumn{4}{|c|}{$\begin{array}{c}\text { Carbono orgânico (OC) } \\
\left(\mu \mathrm{g} \mathrm{m}^{-3}\right)\end{array}$} & \multicolumn{4}{|c|}{$\begin{array}{c}\text { Carbono elementar (EC) } \\
\left(\mu \mathrm{g} \mathrm{m}^{-3}\right)\end{array}$} & \multicolumn{3}{|c|}{$\begin{array}{c}\mathbf{T C} \\
\left(\mu \mathrm{g} \mathrm{m}^{-3}\right)\end{array}$} \\
\hline & Média & $\sigma$ & Máx. & Min & Média & $\sigma$ & Máx. & Min & OC:EC & Média & $\mathbf{N}$ \\
\hline IBP & 3.69 & 2.37 & 13.70 & 0.69 & 1.83 & 1.03 & 5.02 & 0.45 & 2.1 & 5.52 & 100 \\
\hline IFP & 3.62 & 2.33 & 12.47 & 0.37 & 2.19 & 1.65 & 10.32 & 0.29 & 1.8 & 5.82 & 87 \\
\hline FSP & 3.50 & 1.71 & 10.50 & 0.68 & 2.35 & 1.18 & 6.30 & 0.60 & 1.5 & 5.85 & 100 \\
\hline CGH & 6.42 & 4.61 & 28.63 & 2.16 & 7.84 & 3.92 & 21.80 & 1.09 & 0.8 & 14.26 & 92 \\
\hline
\end{tabular}

Tabela 4-5 - Análise descritiva das concentrações carbono orgânico (OC) e elementar (EC) nos filtros de quartzo para as estações amostradoras IFP, FSP, IBP e CGH, onde $\sigma$ representa o desvio padrão da média e $\mathrm{N}$ o número de casos medidos. O material carbonáceo total (TC) é dado pela soma das frações OC e EC. 
A razão OC:EC média observada nas estações IBP, IFP e FSP, foi 2.1, 1.8, 1.6, respectivamente. Apenas no caso de $\mathrm{CGH}$, foi verificada uma razão média menor do que 1 (nesse caso, OC:EC =0.8). Medidas feitas em túneis reportam valores de 2.4 no caso de veículos leves movidos à gasolina, enquanto para veículos pesados movidos a diesel, são apresentados valores próximos de 0.5 (Brito et. al, 2013). Nas estações da FSP e, principalmente, $\mathrm{CGH}$, ambas fortemente impactadas por veículos a diesel (ônibus e caminhões), são verificadas razões OC:EC, em geral, menores comparadas à IFP e IBP. Outra questão importante é que, enquanto as concentrações de EC se mantêm constantes desde a emissão até a deposição, as concentrações de OC tende a aumentar em decorrência dos diferentes processos de formação de aerossol orgânico secundário (SOA). O aumento em concentração de OC influencia positivamente a razão OC:EC.

De modo geral, o material carbonáceo total, ou TC, apresenta grande variabilidade ao longo das séries temporais. Nas estações amostradoras IBP, IFP, FSP as concentrações de TC variam entre 0.7 e $20 \mu \mathrm{g} \mathrm{m}^{-3}$, com valores médios de 5.5 a $6.0 \mu \mathrm{g} \mathrm{m}^{-3}$. No sítio de CGH, por outro lado, verificam-se concentrações na faixa 3.7 - $50.4 \mu \mathrm{g} \mathrm{m}^{-3}$, com concentração média igual a $14.3 \mathrm{\mu g} \mathrm{m}^{-3}$.

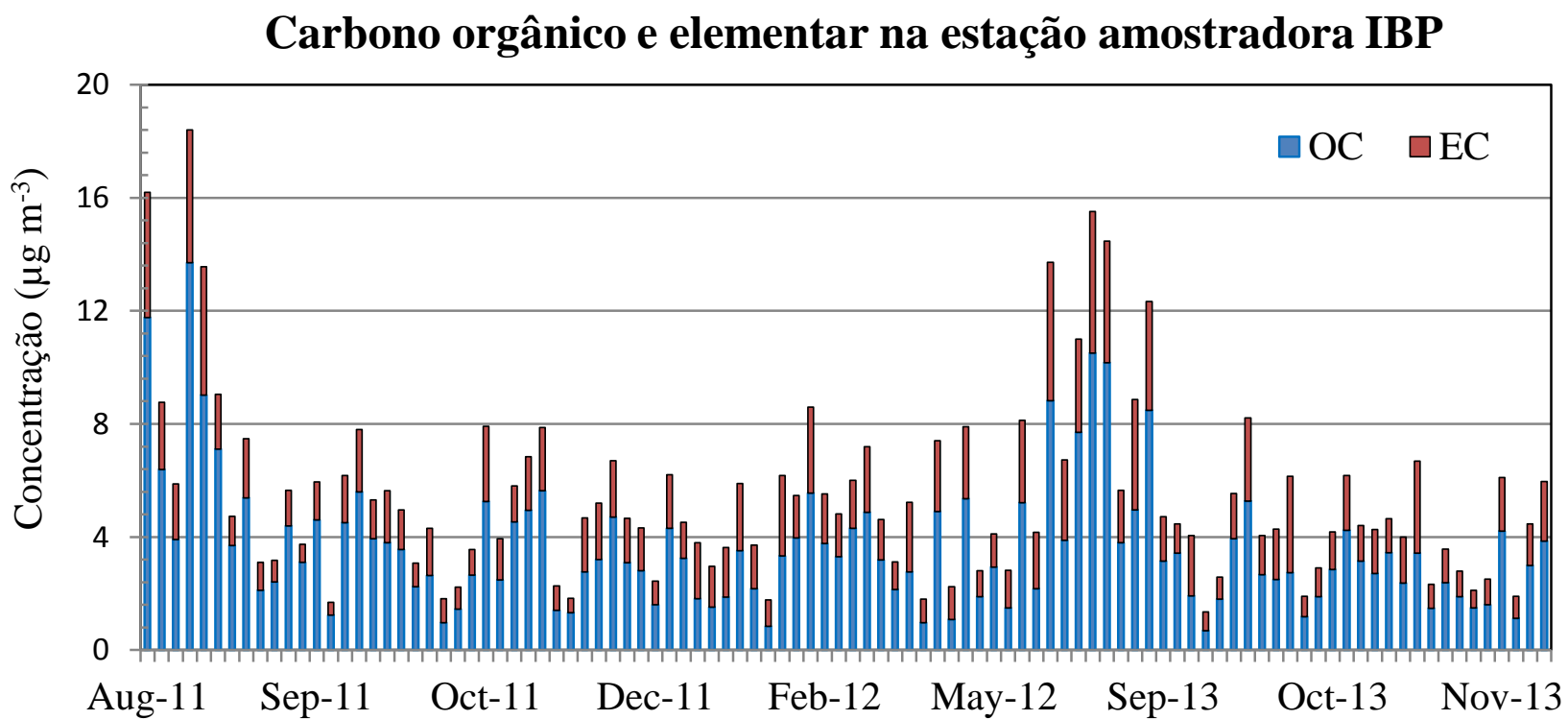

Figura 4-21 Série temporal das concentrações de carbono orgânico e elementar na estação amostradora do Ibirapuera, no período de Agosto de 2011 a Novembro de 2013. 


\section{Carbono orgânico e elementar na estação amostradora IFP}

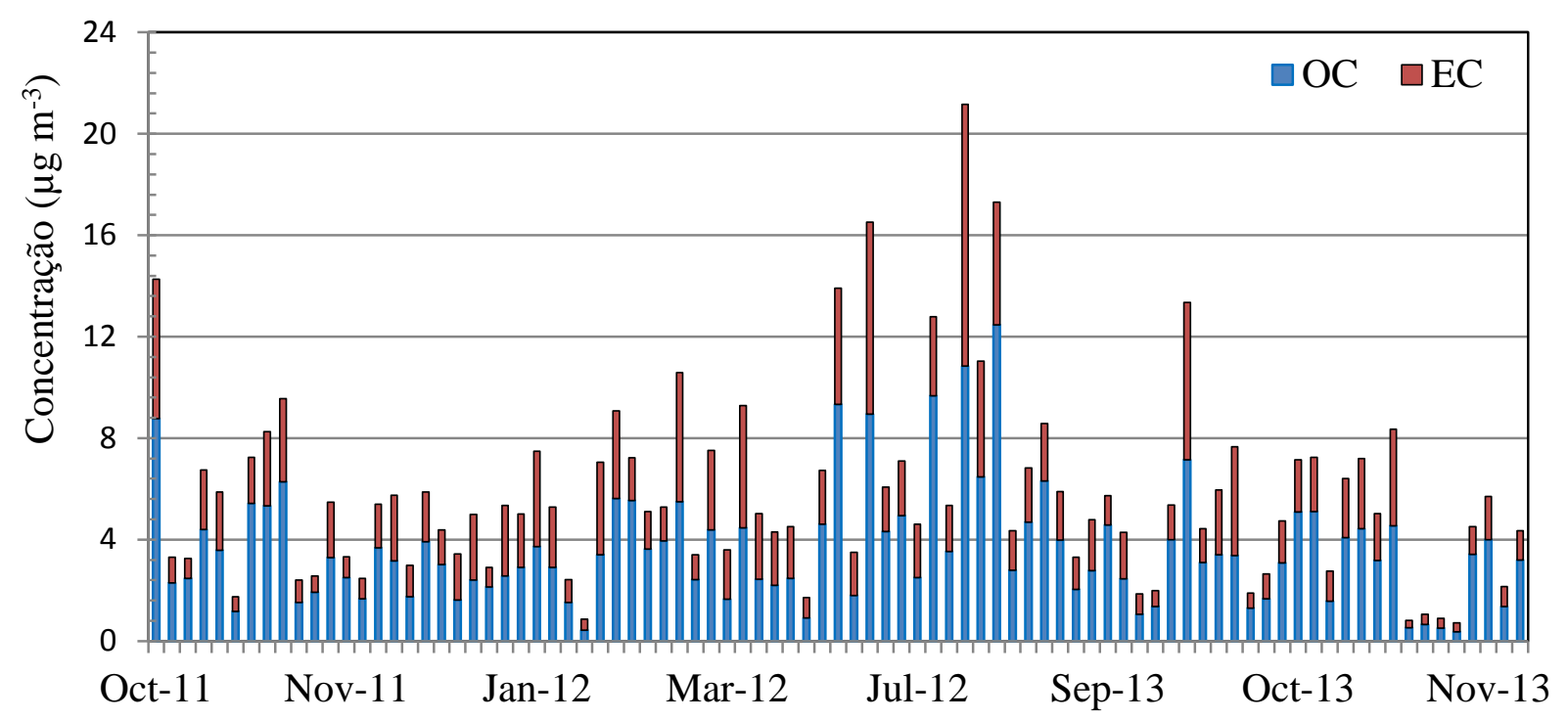

Figura 4-22 - Série temporal das concentrações de carbono orgânico e elementar na estação amostradora do IFUSP, no período de Outubro de 2011 a Novembro de 2013.

\section{Carbono orgânico e elementar na estação amostradora FSP}

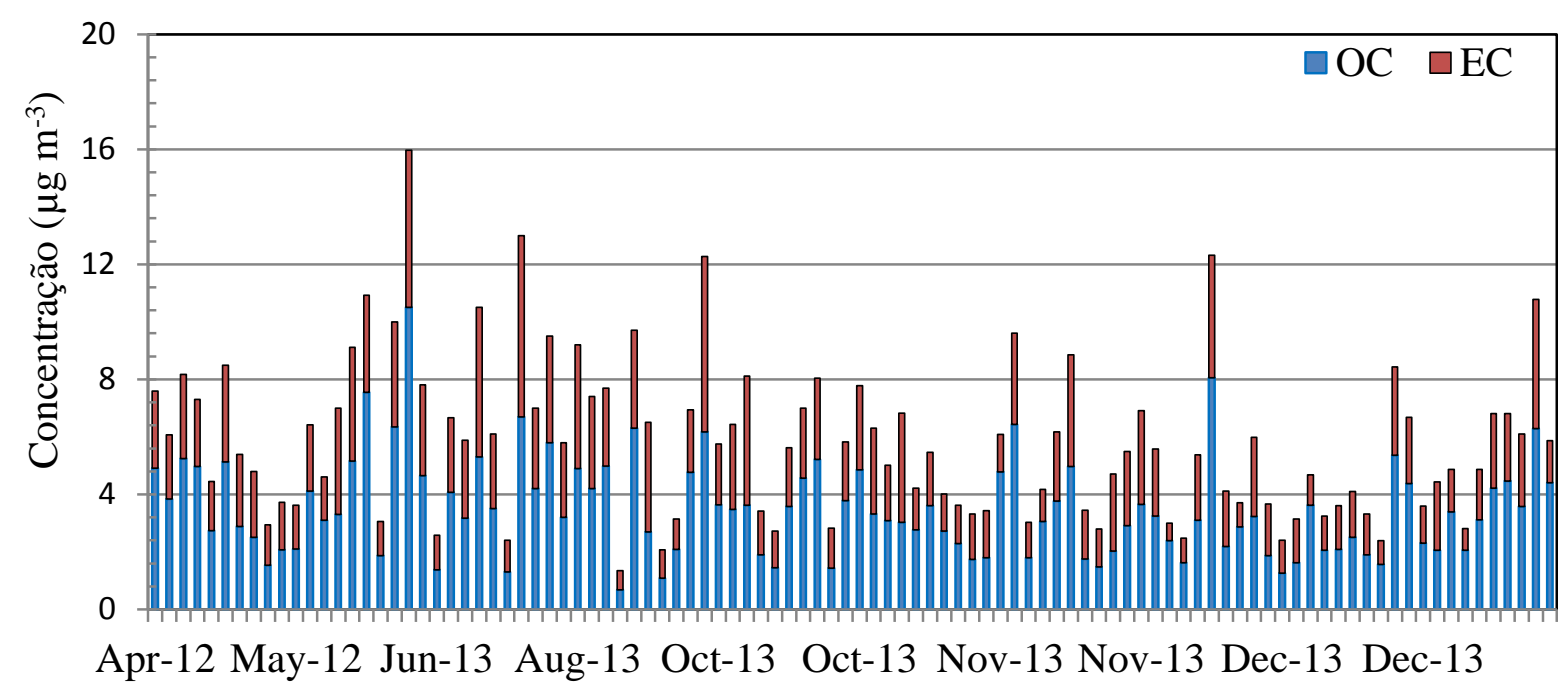

Figura 4-23 - Série temporal das concentrações de carbono orgânico e elementar na estação amostradora de Cerqueira César, no período de Abril de 2012 a Janeiro de 2014. 


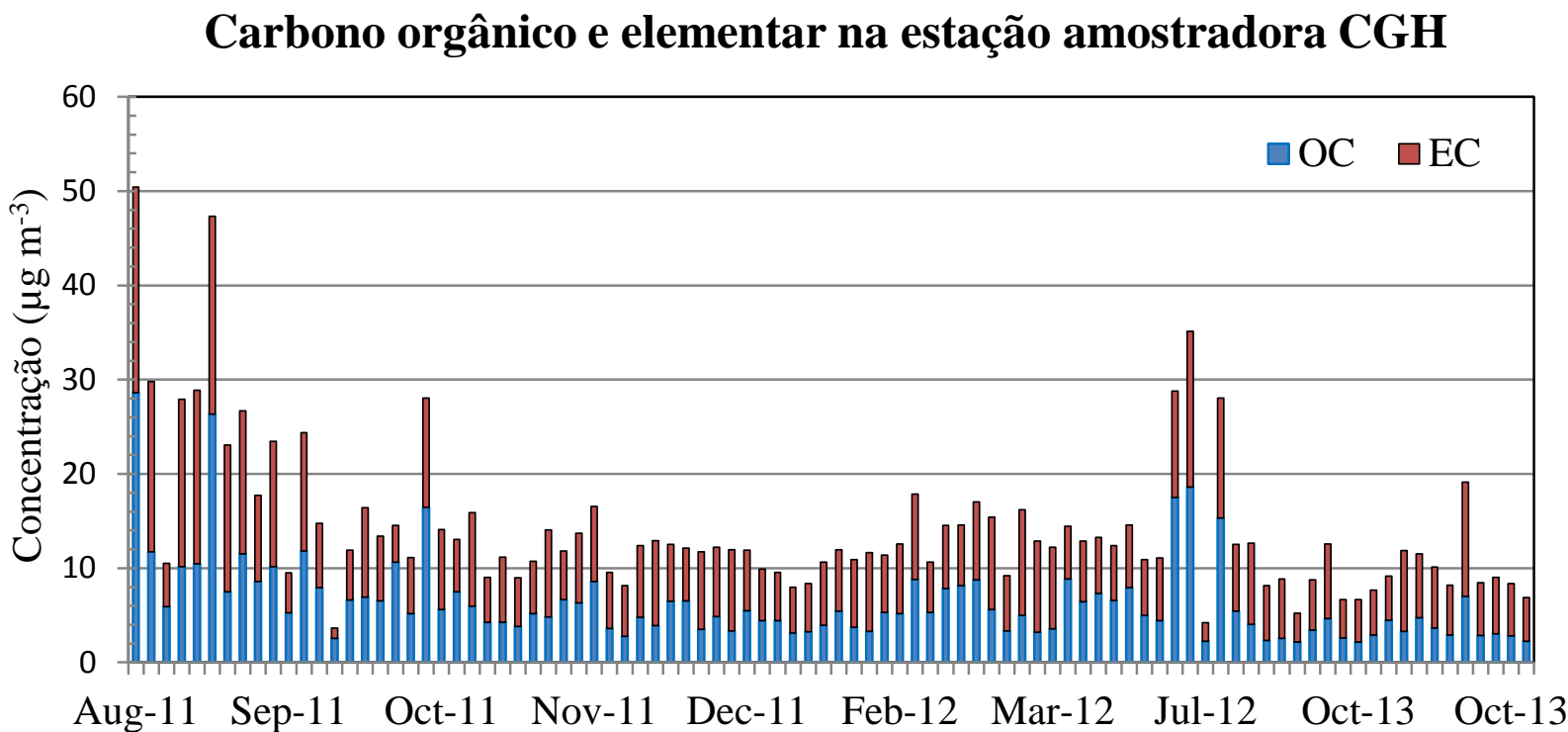

Figura 4-24 - Série temporal das concentrações de carbono orgânico e elementar na estação amostradora de Congonhas, no período de Agosto de 2011 a Novembro de 2013.

A análise conjunta dos filtros das estações IFP, FSP e IBP forneceu informações sobre a sazonalidade das componentes carbonáceas. Nos períodos de inverno (Maio, junho, julho e agosto) e verão (novembro, dezembro, janeiro e Fevereiro) estes valores foram respectivamente $5.05 \mu \mathrm{m}^{-3}$ e $3.06 \mu \mathrm{m}^{-3}$ para OC e $3.05 \mu \mathrm{m}^{-3}$ e $1.79 \mu \mathrm{m}^{-3}$ para EC. A tabela $4-7$ mostra esses resultados.

\begin{tabular}{|c|c|c|c|c|c|c|c|c|}
\hline \multicolumn{9}{|c|}{ OC e EC para o conjunto das estações IFP, FSP e IBP } \\
\hline & \multicolumn{4}{|c|}{ Carbono orgânico (OC) $\left(\mu \mathrm{g} \mathrm{m}^{-3}\right)$} & \multicolumn{4}{|c|}{ Carbono Elementar $(\mathbf{E C})\left(\mu \mathrm{g} \mathrm{m}^{-3}\right)$} \\
\hline & Média & $\boldsymbol{\sigma}$ & Min. & Máx & Média & $\boldsymbol{\sigma}$ & Min. & Máx \\
\hline Verão & 3.06 & 1.45 & 0.36 & 8.06 & 1.79 & 0.88 & 0.35 & 4.49 \\
\hline Inverno & 5.05 & 2.83 & 0.91 & 13.70 & 3.05 & 1.68 & 0.36 & 10.32 \\
\hline
\end{tabular}

Tabela 4-6 - Análise descritiva das concentrações de carbono orgânico e elementar para o conjunto de dados das estações amostradoras IFP, FSP e IBP. São apresentados os resultados para filtros amostrados no inverno (Maio, Junho, Julho e Agosto), no verão (Novembro, Dezembro, Janeiro e Fevereiro), além da série completa. $\sigma$ representa o desvio padrão da média. 


\subsection{Balanço químico de massa das concentrações observadas}

Os resultados apresentados até aqui permitiram o cálculo do balanço químico de massa para o material particulado. A contribuição relativa dos elementos traços para o material particulado pode ser estimada a partir de um fator de conversão das espécies cuja concentração foi medida na forma elementar nos principais compostos inorgânicos que se prevê estarem presentes na forma de aerossol. Os constituintes na forma de aerossol inorgânico podem ser divididos em aerossol marinho, poeira do solo, sulfato, nitrato, amônia e elementos traço (Castanho, 1999; Kleeman et al., 2000).

A contribuição de aerossol marinho é estimada, a partir das concentrações elementares de $\mathrm{Na}$ e $\mathrm{Cl}$, como:

$$
\text { Aerossol Marinho }=\mathrm{Cl}+1.4486 \mathrm{Na}
$$

Onde 1.4486 é a razão da concentração de todos os elementos da água do mar, exceto $\mathrm{Cl}$, pela concentração de $\mathrm{Na}$ também na água do mar (Maenhaut et al. 2005).

A contribuição de elementos de poeira do solo pode ser estimada pelas concentrações previstas de óxidos de $\mathrm{Al}, \mathrm{Si}, \mathrm{Ca}$, Ti e Fe:

\section{Poeira do solo $=1.16 *(1.90 \mathrm{Al}+2.15 \mathrm{Si}+1.41 \mathrm{Ca}+1.67 \mathrm{Ti}+2.09 \mathrm{Fe})$}

(Equação 4.2)

Onde o fator 1.16 foi determinado para compensar a exclusão dos compostos $\mathrm{MgO}$, $\mathrm{Na}_{2} \mathrm{O}, \mathrm{K}_{2} \mathrm{O}$ e $\mathrm{H}_{2} \mathrm{O}$ do cálculo da massa. Os fatores multiplicativos de cada um dos elementos se referem à conversão destes em seus óxidos mais comuns (Maenhaut et al. 2005).

Para a estimativa da contribuição do elemento $\mathrm{S}$ em massa para o total de $\mathrm{PM}_{2.5}$, como discutido na seção 5.2, a conversão de sua concentração elementar em sulfato $\left(\mathrm{SO}_{4}\right)$ através de um fator multiplicativo igual a 3 é adequada e consistente com as medidas de $\mathrm{SO}_{4}$ feitas por cromatografia iônica. Quanto às frações de nitrato e amônia, foram utilizadas as concentrações médias determinadas por IC. A soma da massa de todos os elementos (exceto S) não atribuídos à poeira do solo ou aerossol marinho é referida como elementos traço. 
A contribuição de partículas de aerossóis carbonáceos para o material particulado pode ser calculada pela soma da componente orgânica (OA) e da componente absorvedora de luz (EC ou BC). A contribuição em massa de material orgânico (do inglês Organic Matter - OM) pode ser estimada a partir da concentração de carbono orgânico medido. $\mathrm{O}$ fator de conversão é uma estimativa da massa dos outros elementos associados ao composto juntamente com o carbono, como átomos de oxigênio, hidrogênio e nitrogênio. Há grande incerteza na estimativa desse fator, já que existem diversos tipos de compostos orgânicos presentes na atmosfera e estes ainda não são integralmente conhecidos. Nesse trabalho, a OM foi estimada multiplicando o OC medido por um fator 1.4 (Maenhaut et al. 2005).

As figuras 4-25, 4-26 e 4-27 mostram a série temporal do $\mathrm{PM}_{2.5}$ (linha sólida) e a soma das componentes identificadas no balanço químico de massa (colunas empilhadas) para as estações FSP, IBP e IFP, respectivamente. Na estação amostradora de Congonhas, a soma EC + $\mathrm{OM}$ excedeu a concentração do $\mathrm{PM}_{2.5}$ em $85 \%$ dos filtros analisados. Esse resultado comprova que, de fato, não foi possível discriminar as frações de particulado fino e grosso. No caso da estação amostradora IFP, não foi possível medir as frações carbonáceas (OM e EC) para alguns filtros, o que é observado na figura 4-27.

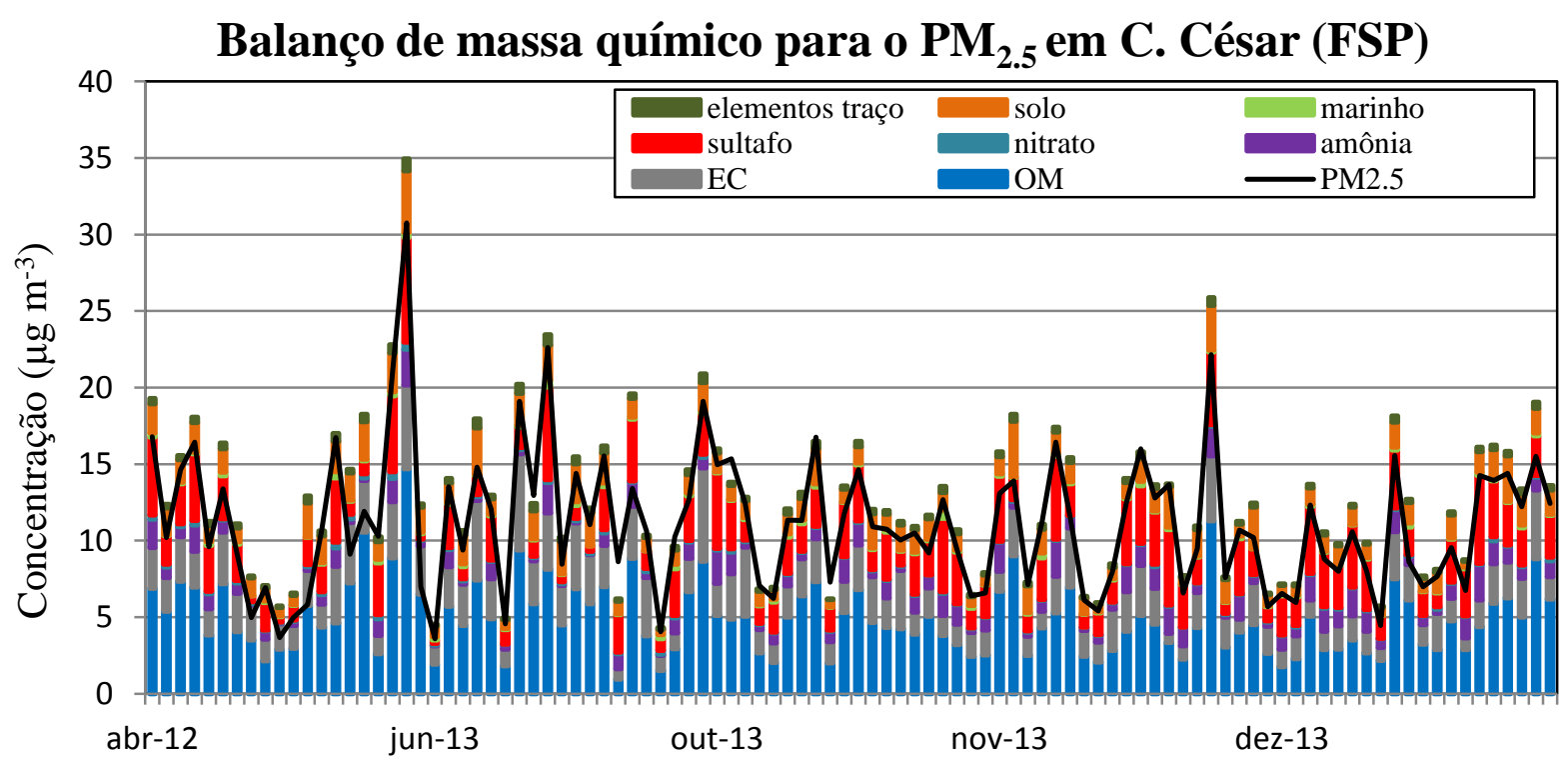

Figura 4-25 Balanço de massa químico para o material particulado fino na estação amostradora de Cerqueira César. Em colunas empilhadas estão as contribuições das componentes do balanço. Em linha a concentração do $\mathrm{PM}_{2.5}$ medido. 


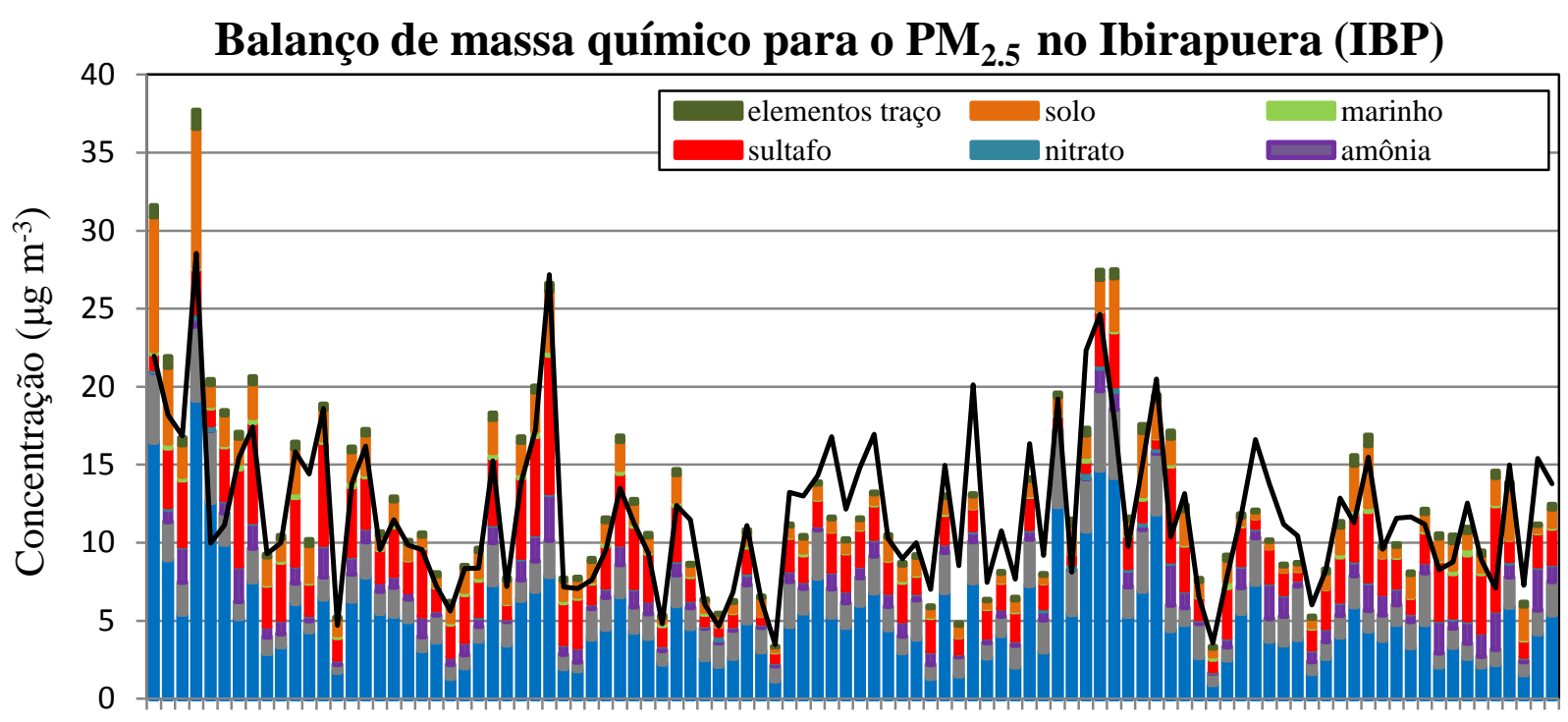

ago-11 set-11 out-11 out-11 nov-11 jan-12 fev-12 mar-12 jun-12 set-13 out-13 out-13 nov-13

Figura 4-26 - Balanço de massa químico para o material particulado fino na estação amostradora do Ibirapuera. Em colunas empilhadas estão as contribuições das componentes do balanço. Em linha a concentração do $\mathrm{PM}_{2.5}$ medido.

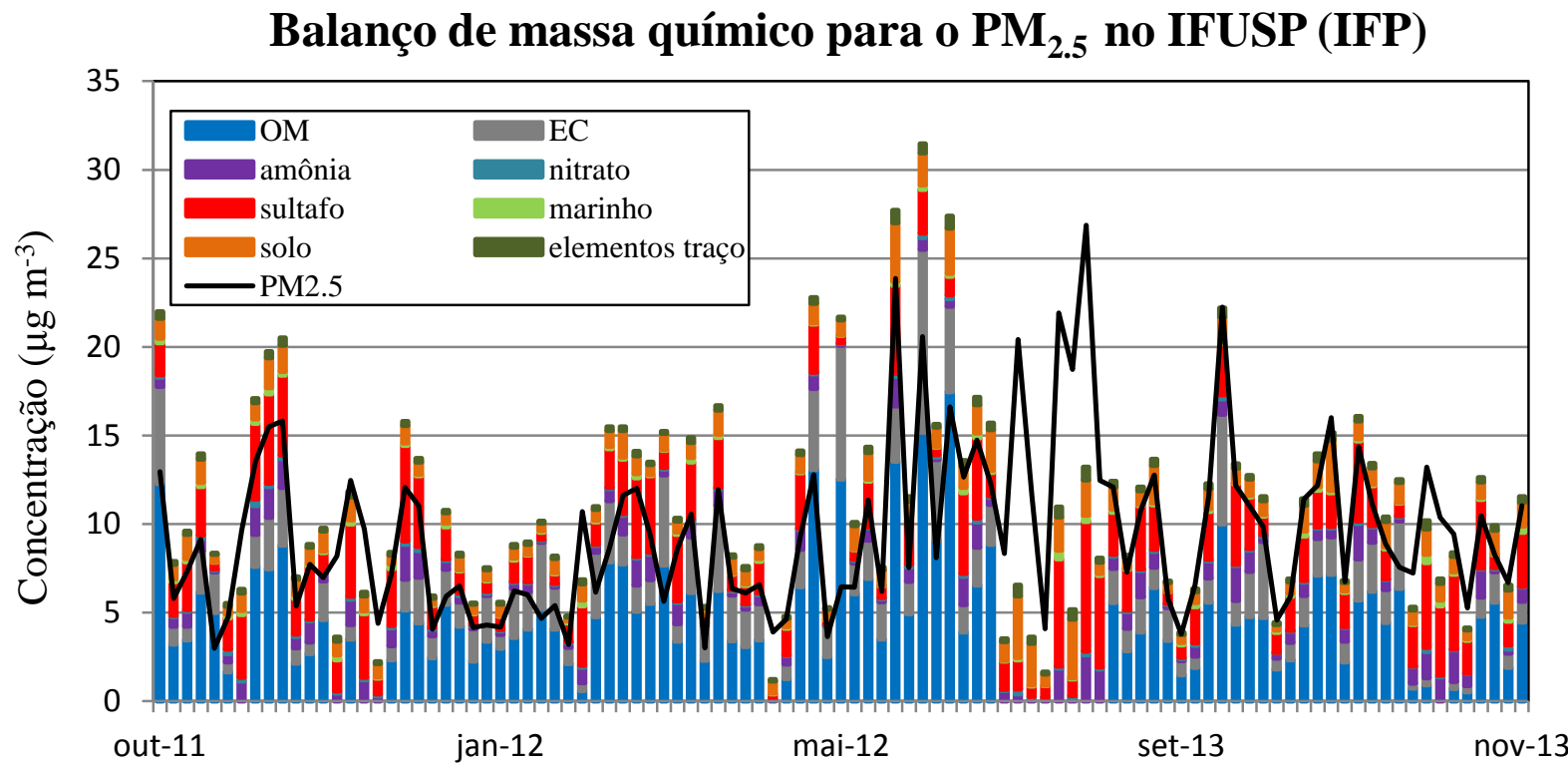

Figura 4-27 - Balanço de massa químico para o material particulado fino na estação amostradora do IFUSP. Em colunas empilhadas estão as contribuições das componentes do balanço. Em linha a concentração do $\mathrm{PM}_{2.5}$ medido. 
A tabela 4-8 apresenta as porcentagens médias do $\mathrm{PM}_{2.5}$ atribuídas a cada tipo de aerossol na fração fina, enquanto a tabela 4-9 apresenta estes resultados para a fração grossa do aerossol.

\begin{tabular}{ccccccc} 
& \multicolumn{2}{c}{ Ibirapuera } & \multicolumn{2}{c}{ IFUSP } & \multicolumn{2}{c}{ Cerqueira César } \\
\hline Componente & $\boldsymbol{\%}$ & $\boldsymbol{\sigma}$ & $\boldsymbol{\%}$ & $\boldsymbol{\sigma}$ & $\boldsymbol{\%}$ & $\boldsymbol{\sigma}$ \\
\hline Aerossol Orgânico (OM) & 42 & 15 & 58 & 31 & 45 & 14 \\
EC & 16 & 7 & 27 & 20 & 22 & 9 \\
Amônia & 7.4 & 5.4 & 8 & 4 & 7.9 & 4.6 \\
Nitrato & 0.9 & 0.8 & 1.3 & 0.7 & 1.1 & 0.7 \\
Sulfato & 23 & 13 & 24 & 11 & 22 & 10 \\
Aerossol Marinho & 1.5 & 1.0 & 1.6 & 1.0 & 1.5 & 1.1 \\
Poeira de Solo & 12 & 7 & 11 & 4 & 13 & 5 \\
Elementos Traço & 1.3 & 1.2 & 1.4 & 1.2 & 1.5 & 1.1 \\
Soma & 104 & 50 & 132 & 72 & 114 & 45 \\
\hline
\end{tabular}

Tabela 4-7- Atribuição percentual média da massa gravimétrica aos diferentes tipos de aerossol para o material particulado fino nas estações Ibirapuera, IFUSP e Cerqueira César, onde $\sigma$ é o desvio padrão associado.

\section{Ibirapuera IFUSP Cerqueira César}

\begin{tabular}{ccccccc}
\hline Componente & $\boldsymbol{\%}$ & $\boldsymbol{\sigma}$ & $\boldsymbol{\%}$ & $\boldsymbol{\sigma}$ & $\boldsymbol{\%}$ & $\boldsymbol{\sigma}$ \\
\hline EBC & 2.1 & 0.7 & 2.4 & 0.8 & 2.6 & 0.8 \\
Amônia & 0.4 & 0.6 & 0.4 & 0.5 & 0.5 & 0.5 \\
Nitrato & 3.9 & 2.3 & 5.7 & 3.2 & 4.7 & 2.5 \\
Sulfato & 4.6 & 3.2 & 5.8 & 2.7 & 5.8 & 2.7 \\
Aerossol Marinho & 2.8 & 3.9 & 3.6 & 4.3 & 3.2 & 3.9 \\
Poeira de Solo & 38 & 17 & 39 & 7 & 40 & 6 \\
Elementos Traço & 2.5 & 0.9 & 2.4 & 0.9 & 2.7 & 0.9 \\
Soma & 54 & 29 & 59 & 19 & 59 & 17 \\
\hline
\end{tabular}

Tabela 4-8- Atribuição percentual média da massa gravimétrica aos diferentes tipos de aerossol para o material particulado grosso nas estações Ibirapuera, IFUSP e Cerqueira César, onde $\sigma$ é o desvio padrão associado.

$\mathrm{Na}$ fração fina verificou-se contribuição dominante da componente orgânica de aerossóis, com média percentual de 42, 45 e 58\% da massa média medida nas estações IBP, FSP e IFP, respectivamente. Partículas de sulfato também tiveram impacto majoritário nas concentrações do $\mathrm{PM}_{2.5}$, entre 20 e 25\%; juntamente com aerossóis absorvedores de radiação (black carbon ou carbono elementar): a participação de partículas de EC ou EBC variou, em geral, na faixa de 15 
a $30 \%$ da massa na fração fina. Em menor escala, emissões de poeira do solo e aerossóis inorgânicos de amônia foram atribuídas a12 e 8\% da massa na fração fina, enquanto aerossol marinho, aerossol de nitrato e os demais elementos traços somam menos de $5 \%$ em relação ao $\mathrm{PM}_{2.5}$. A massa total modelada, dada pela soma das componentes, representou 105 e $115 \%$ da massa medida, nas estações amostradoras IBP e FSP. No caso específico da estação amostradora do IFUSP, a massa modelada foi igual a $130 \%$ da massa medida. A diferença encontrada entre o balanço químico de massa e a massa medida pode estar associado a alguns fatores passíveis de erros como, por exemplo, a adoção de um mesmo fator multiplicativo na conversão do carbono orgânico em massa orgânica para as três estações amostradoras.

Na fração grossa, predominam as emissões de ressuspensão de poeira de solo, responsáveis, em média, por cerca de $40 \%$ da massa do aerossol medida. Partículas de sulfato, black carbon, não representam frações relevantes do particulado, como na moda fina. Aerossóis marinhos e de nitrato apresentam contribuição percentual um pouco maior na fração grossa. O modelo de balanço químico de massa não pode explicar mais que $60 \%$ das concentrações medidas na fração grossa. No entanto, a coleta de material carbonáceo foi feita apenas para a fração fina, de modo que não há medidas de carbono orgânico para a fração grossa. Assim, é possível que o restante da concentração em massa do aerossol na fração grossa se deva ao material orgânico não medido.

\subsection{A análise dos termogramas na análise térmica diferencial.}

Como discutido na seção 4.4, a aplicação do protocolo de temperatura EUSAAR_2 na análise termo-óptica do material carbonáceo quantifica diferentes frações de carbono orgânico e elementar. O carbono orgânico é definido operacionalmente como OC = OC1 + OC2 + OC3 + $\mathrm{OC} 4+\mathrm{PC}$, enquanto o carbono elementar é definido como $\mathrm{EC}=\mathrm{EC} 1+\mathrm{EC} 2+\mathrm{EC} 3+\mathrm{EC} 4$. Essas frações diferem-se quanto a sua volatilidade e podem ser interpretadas como uma assinatura da volatilidade das fontes do material carbonáceo (Gilardoni et al. 2011).

Na figura 4-28 são apresentados os valores médios de cada um das componentes de OC e EC obtidos para as estações de CGH, IFP, FSP e IBP. Observa-se uma alta similaridade para as concentrações nas estações de IFP, FSP e IBP em todas as frações e sua distribuição. A 
estação CGH apresenta um perfil diferente, conforme discutido anteriormente. Observa-se que, de um modo geral, as concentrações de OC estão associadas majoritariamente à segunda fração (OC2), volatilizada a uma temperatura de $300^{\circ} \mathrm{C}$. Esta componente representa de 30 a $35 \%$ do carbono orgânico total. Foram verificadas também altas concentrações de carbono pirolítico, componente orgânica de mais baixa volatilidade carbonizada durante o primeiro estágio da análise e medida durante o segundo estágio de análise.

As concentrações de carbono elementar distribuem-se principalmente nas três primeiras componentes (EC1, EC2 e EC3). É possível notar que, nas quatro estações amostradoras, as concentrações médias aumentam a cada passo de temperatura, sendo máximas no pico de EC a $700^{\circ} \mathrm{C}$ (EC3). Esse resultado é exatamente o oposto do verificado em aerossóis de queima de biomassa fresca na Amazônia, obtidos por Arana (2014), onde se destaca a fração EC1 (oxidada a $500^{\circ} \mathrm{C}$ ). Quanto ao pico EC4 (fração de EC que evolui a $850^{\circ} \mathrm{C}$ ), verifica-se um alto impacto desta componente na estação amostradora de Cerqueira César (FSP). Em termos percentuais, $25 \%$ do carbono elementar é quantificado neste passo de temperatura, indicando possivelmente o impacto de emissões de veículos pesados, característica deste local de amostragem. Em Congonhas, estação de mais alto impacto veicular e mais altas concentrações de OC e EC, são notáveis os altos picos de EC, acentuados nas quatro frações (EC1, EC2, EC3, EC4). Entretanto, no caso do OC, embora as concentrações de CGH sejam sempre maiores, apenas os picos relativos às temperaturas de $300 \mathrm{e}$ de $450^{\circ} \mathrm{C}(\mathrm{OC} 2$ e $\mathrm{OC} 3$, respectivamente) diferem das demais estações por ordens de grandeza. Como o diferencial das emissões em Congonhas é a alta participação veicular a diesel, é possível que o impacto deste tipo de emissão seja maior justamente nessas frações, OC2 e OC3. Mas, apenas por essa análise não é possível afirmar a natureza das componentes carbonáceas. 
Concentração média das frações de carbono

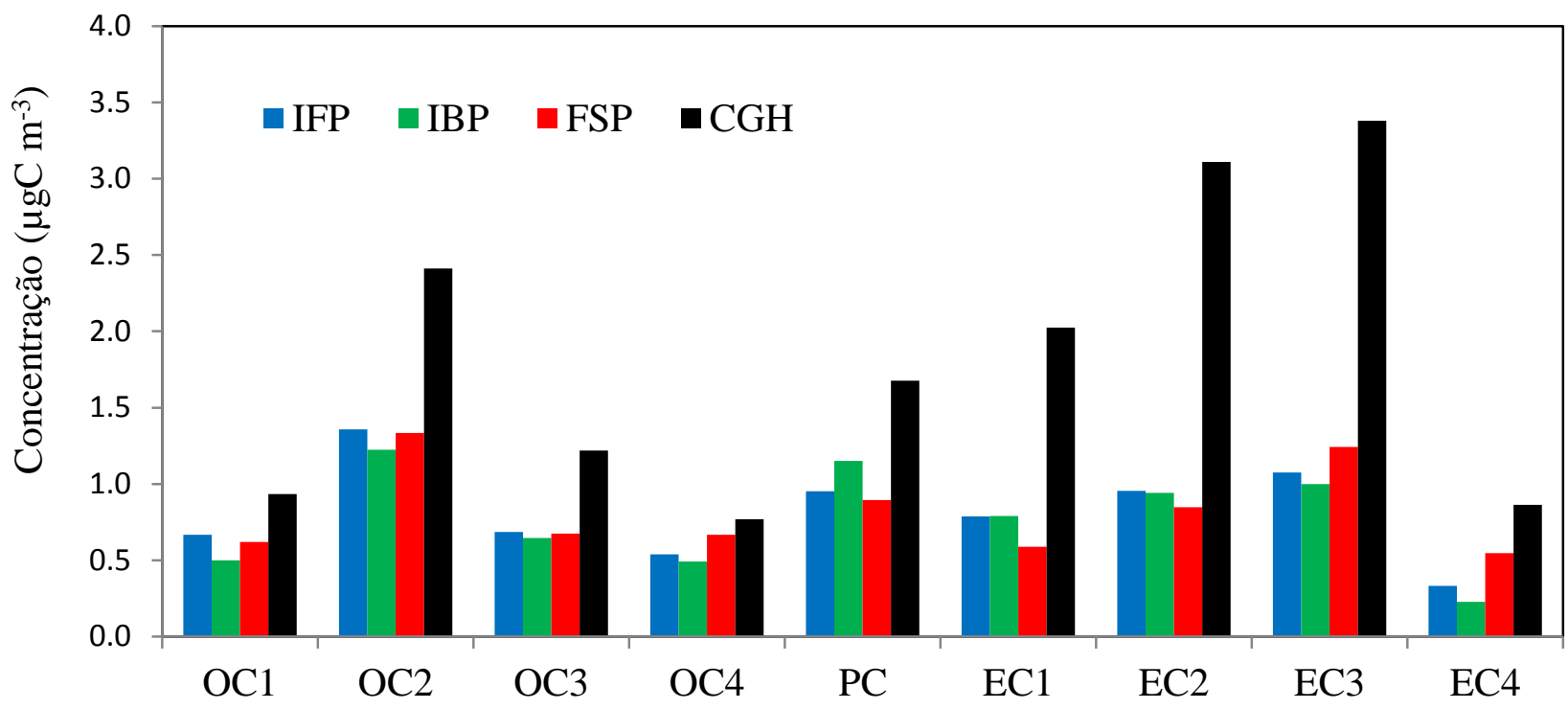

Figura 4-28 - Concentração média das nove frações carbonáceas discriminadas para as quatro estações amostradoras do projeto FONTES.

Novamente, uma análise do conjunto dos dados das estações amostradoras IFP, IBP e FSP foi empregada a fim de verificar algum perfil sazonal com relação às concentrações de cada uma das componentes carbonáceas do material particulado. A figura 4-29 apresenta os valores médios calculados para os meses de inverno (Maio, Junho, Julho e Agosto) e verão (Outubro, Novembro, Dezembro e Janeiro). Novamente observam-se concentrações maiores no período de inverno para todas as componentes, exceto EC4. Nesse caso, a média foi $10 \%$ menor em relação ao período do verão. As componentes $\mathrm{OC} 3, \mathrm{EC} 1$ e EC2, em particular, mais que dobraram nos meses de inverno, período em que a dispersão de poluentes é dificultada. 


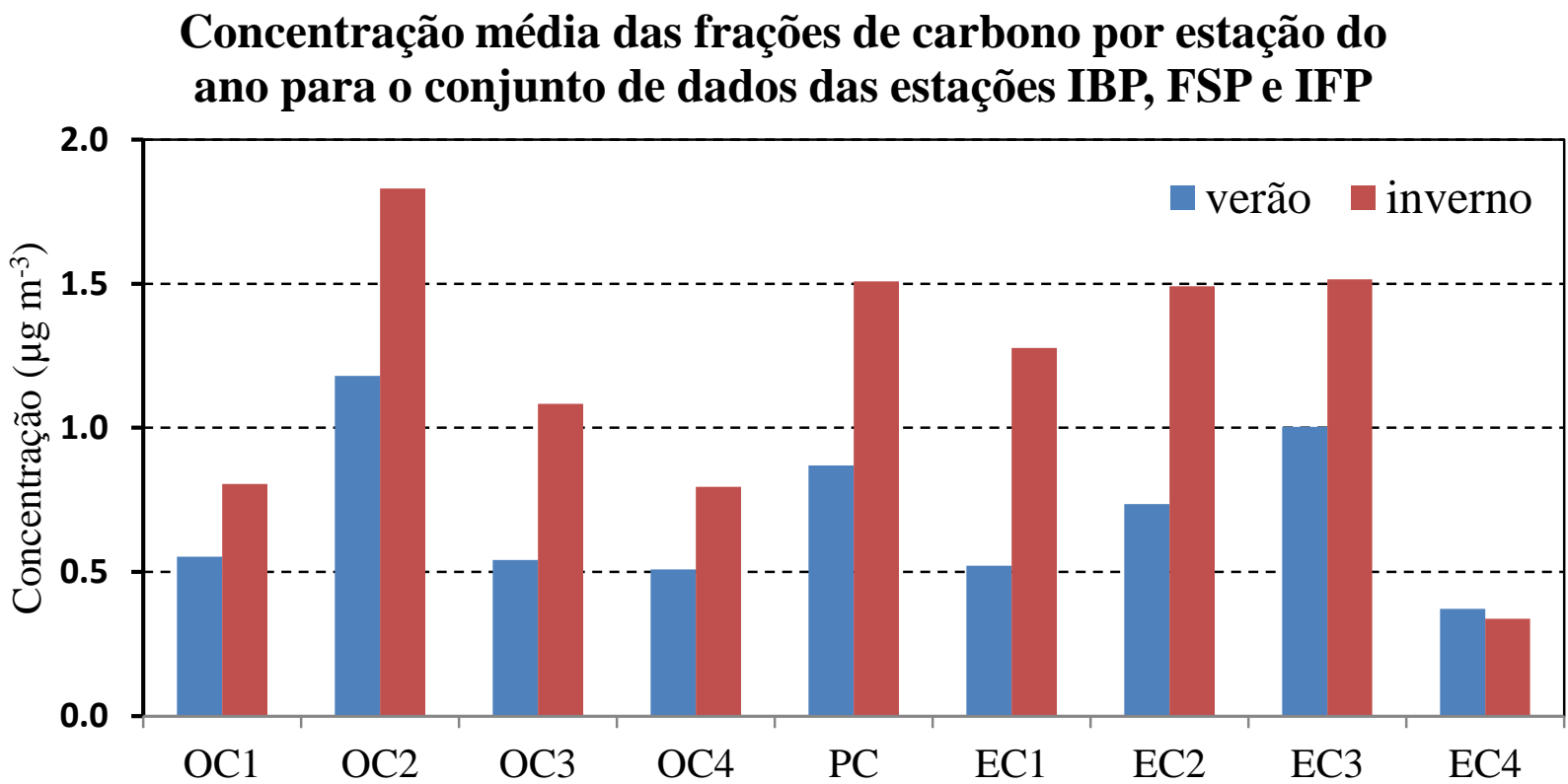

Figura 4-29 - Concentração média das frações carbonáceas discriminadas para o conjunto de dados das estações amostradoras IFP, IBP e FSP. Concentrações calculadas para os meses de inverno (Maio, Junho, Julho e Agosto) e verão (Novembro, Dezembro, Janeiro e Fevereiro).

\subsection{Correlação entre as medidas de Black Carbon Equivalente e Carbono Elementar}

Como discutido na seção 1.2.1, o termo black carbon (BC) se refere de forma qualitativa às substâncias carbonáceas absorvedoras de luz presentes no aerossol atmosférico. Medidas obtidas a partir de técnicas de absorção óptica são referidas como equivalent black carbon (EBC), enquanto medidas obtidas a partir de técnicas que determinam especificamente a quantidade de carbono presente no material particulado na forma elementar são referidas como elemental carbon (EC). Isto é, EC e EBC referem-se a medidas obtidas por técnicas diferentes e baseadas em propriedades distintas dos aerossóis. No entanto, espera-se verificar associação entre essas duas medidas, visto que a maior parte do material carbonáceo absorvedor de luz se encontra na forma de carbono elementar (Gilardoni et al., 2011).

Como parte da validação das medidas obtidas, verificou-se a correlação entre as concentrações de EBC e de EC medidas em paralelo nos filtros Nuclepore (na fração fina) e de Quartzo, respectivamente. Nas figuras 4-30 a 4-32 são apresentadas as regressões lineares entre EBC (na fração fina) e EC para as estações amostradoras IFUSP, Ibirapuera e Cerqueira César. 
Regressão linear entre as medidas de EC e BC equivalente para a estação amostradora do Ibirapuera

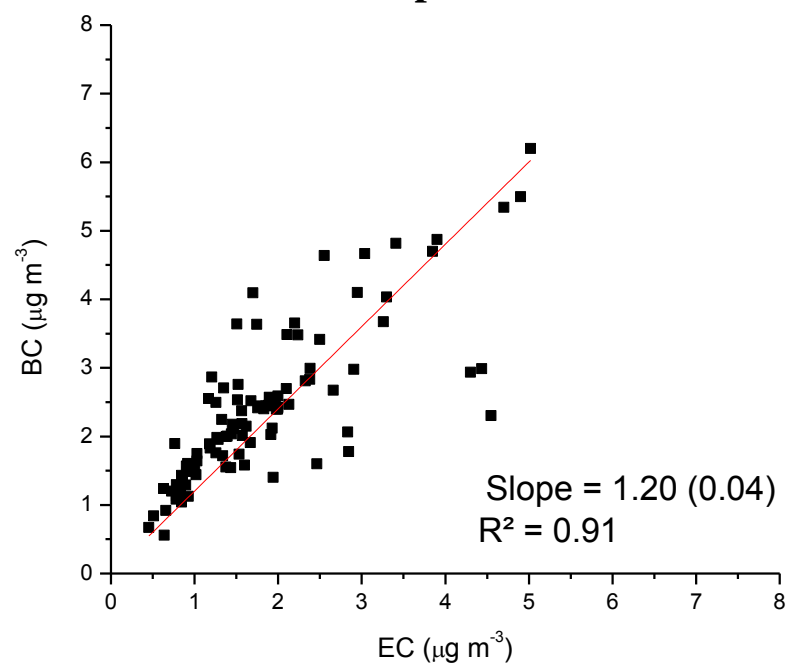

Figura 4-30 - Regressão linear entre as concentrações de black carbon equivalente na fração fina e de carbono elementar para a estação amostradora do Ibirapuera.
Regressão linear entre as medidas de EC e BC equivalente para a estação amostradora de Cerqueira César

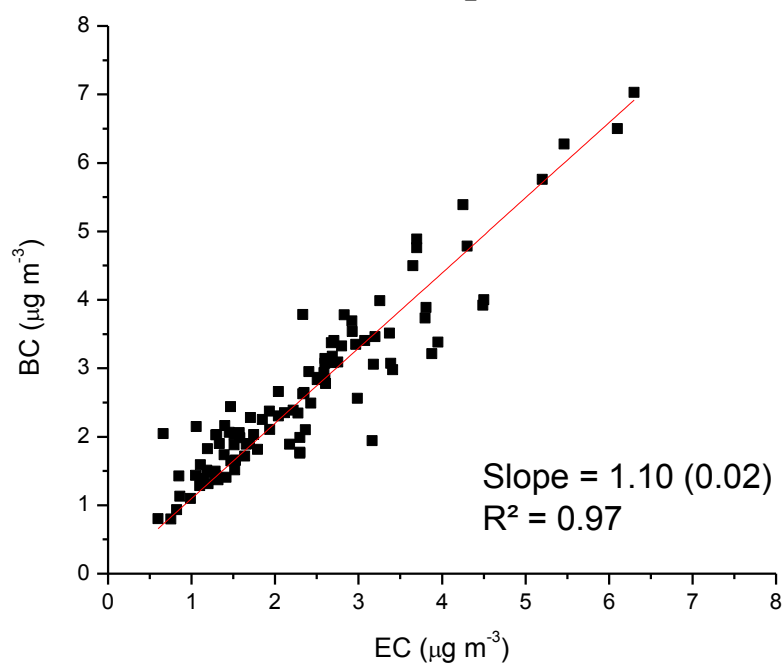

Figura 4-31 - Regressão linear entre as concentrações de black carbon equivalente na fração fina e de carbono elementar para a estação amostradora de Cerqueira César.

\section{Regressão linear entre as medidas de EC e BC} equivalente para a estação amostradora do IFUSP

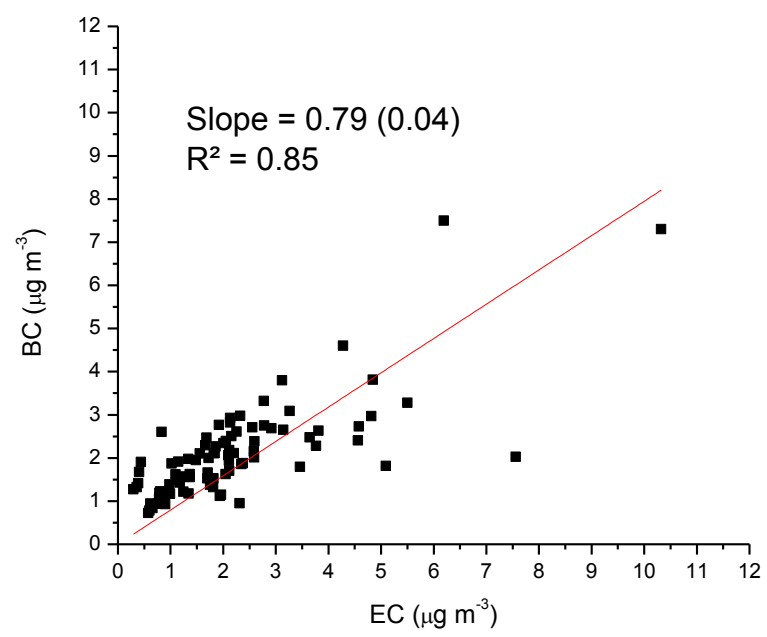

Figura 4-32 - Regressão linear entre as concentrações de black carbon equivalente na fração fina e carbono elementar para a estação amostradora do IFUSP. 
As curvas de calibração obtidas foram estatisticamente significativas dentro de um intervalo de confiança de $95 \%$. Os coeficientes de correlação $\mathrm{R}^{2}$ ajustados foram iguais a $0.91 \mathrm{e}$ 0.97 para Ibirapuera e Cerqueira César, respectivamente, enquanto na estação amostradora do IFUSP, obteve-se um valor de $\mathrm{R}^{2}$ menor (0.85). Como apresentado na seção 4.6, para a estação do IFUSP não foi possível determinar as concentrações de EC para todos os filtros, o que justifica este resultado. No entanto, a incerteza no coeficiente de regressão linear ainda esteve abaixo de 5\% inclusive para as medidas da estação IFUSP.

No caso das estações Ibirapuera e Cerqueira César, foram obtidos coeficientes de regressão linear maiores que a unidade, indicando possivelmente a presença de substâncias absorvedoras de luz além do EC. Como discutido também na seção 1.2.1, é verificada (Andreae e Gelencsér, 2006) a presença de partículas de carbono orgânico absorvedoras de radiação no espectro visível (brown carbon ou $\mathrm{BrC}$ ). Contudo não é possível estimar a contribuição do $\mathrm{BrC}$ apenas por esta análise uma vez que as concentrações de EC e EBC são obtidas utilizando-se filtros diferentes e técnicas baseadas em diferentes propriedades. Além disso, enquanto a refletância é baseada na absorção de luz de comprimento de onda de 550nm, na análise termoóptica monitora-se a transmitância de um laser de 670nm. A fração de OC absorvedora de luz no espectro visível (BrC) consiste de uma complexa mistura de compostos orgânicos sem uma definição analítica formal. Por fim, para a estação do IFUSP, obteve-se um coeficiente de regressão linear igual a 0.87, indicando concentrações de EC maiores que as concentrações de EBC, o que não pôde ser explicado. 


\section{Quantificação de fontes na RMSP: resultados da aplicação dos modelos receptores à fração fina do material particulado}

Para a identificação e quantificação de fontes foram utilizados dois modelos receptores: a Análise de Fatores Principais Absoluta (PFA/APFA) e a Matriz de Fatoração Positiva (PMF), descritos na seção 3.5. As análises foram aplicadas à fração fina do material particulado $\left(\mathrm{PM}_{2.5}\right)$ para as estações amostradoras IBP, IFP e FSP individualmente. Além disso, em vista da grande similaridade encontrada na composição química do particulado nestas estações, foi realizada a análise do conjunto dessas estações, totalizando cerca de 300 amostras. Finalmente, empregouse a análise das 300 amostras incluindo as nove frações carbonáceas, a fim de caracterizá-las. A junção de 300 amostras faz com que a estatística seja mais robusta e permite uma análise global regional na RMSP. Quanto às variáveis utilizadas no modelo, além das espécies carbonáceas foram utilizadas as concentrações elementares medidas por XRF, os compostos iônicos determinados por cromatografia iônica (IC), o black carbon equivalente e o $\mathrm{PM}_{2.5}$.

Antes da análise dos resultados foi seguida uma rotina de pré-tratamento de dados, a fim de validar a base de dados que será analisada pelos modelos estatísticos. Foram identificadas eventuais ocorrências durante os processos de amostragem e/ou medida que pudessem comprometer os valores das mesmas, bem como possíveis valores determinados abaixo dos limites de detecção. Por fim foram identificados outliers por regressão linear múltipla entre diferentes grandezas. Quando necessário e possível, foram feitas também estimativas de valores faltantes utilizando regressão linear múltipla, quando o número de valores faltantes não atingisse 5\% do número de amostras para uma dada variável (Castanho, 1999; Gerab, 1996).

Os resultados obtidos na aplicação dos diferentes modelos receptores (APFA e PMF) não convergiram, de modo que foram verificadas diferenças na atribuição de fontes de material particulado. Embora o modelo PMF, diferentemente do APFA, convirja necessariamente para soluções positivas, o que têm mais sentido físico, muitos de seus parâmetros podem ser compreendidos e executados de forma diferente, a critério do analista e, dessa forma, sujeitos a erros de interpretação. A APFA, por outro lado mostrou-se uma técnica de fácil utilização e de interpretação mais direta, uma vez que na PFA a escolha do número de fatores principais é baseada em critérios mais objetivos e é menos dependente da interpretação do analista. 
O modelo PMF não convergiu dentro dos critérios estatísticos aceitáveis e, além disso, não foi verificada consistência entre os resultados da quantificação de fontes para as diferentes estações amostradoras utilizadas na aplicação dos modelos receptores. Por outro lado, os resultados obtidos na APFA para as diferentes estações amostradoras foram consistentes entre si. Com base nessas considerações, optou-se pela utilização apenas da análise de fatores principais para a quantificação de fontes de fontes de aerossóis na RMSP. A seguir serão discutidos detalhadamente os resultados obtidos para cada estação individualmente, bem como para a análise conjunta dessas medidas e a aplicação do modelo incluindo as nove frações carbonáceas obtidas pela técnica termo-ópticas.

\subsection{Resultados da APFA aplicada aos dados da estação Ibirapuera (IBP)}

As medidas de composição de aerossóis da estação amostradora do Ibirapuera (IBP) foram obtidas a partir da coleta e análise de 101 amostras de material particulado. O modelo receptor foi aplicado às variáveis sem valores faltantes, totalizando 31 espécies. O número de fatores retidos pelo modelo é determinado a partir da análise de autovalores e autovetores da matriz de correlação dos dados. Foram identificados seis fatores capazes de explicar $86,1 \%$ da variabilidade dos dados originais. A inclusão de um sétimo fator principal no modelo (com autovalor igual a 0.75 , portanto menor que a unidade) foi descartada pois representaria apenas $2.42 \%$ a mais de explicação para a variabilidade dos dados e seu autovalor é muito menor que 1 .

Os resultados da PFA são mostrados na tabela 5-1 onde as comunalidades representam a fração da variabilidade de cada espécie que é explicada pelo modelo. Observam-se, para a maioria das espécies, comunalidades superiores a 0.9, que explicam mais de $90 \%$ da variabilidade das medidas para aquela variável. Apenas os íons $\mathrm{Mg}$ e $\mathrm{Cl}$ tiveram menos de 70\% da sua variabilidade explicada e, portanto, a solução da PFA com 6 fatores pode ser considerada satisfatória. Ainda na tabela 5-1, são apresentados os factor loadings obtidos após a rotação VARIMAX, indicando a correlação entre cada uma das variáveis com os fatores principais. As associações majoritárias em cada fator e em cada variável (valores em negrito) permitiram a extração de seis componentes que podem ser interpretadas como: 


\begin{tabular}{|c|c|c|c|c|c|c|c|}
\hline \multirow{2}{*}{ Espécie } & \multicolumn{6}{|c|}{ Fator principal } & \multirow{2}{*}{ Comunalidades } \\
\hline & 1 & 2 & 3 & 4 & 5 & 6 & \\
\hline $\mathbf{T i}$ & 0.95 & 0.05 & 0.20 & 0.09 & 0.09 & 0.09 & 0.97 \\
\hline Al & 0.95 & 0.07 & 0.19 & 0.02 & 0.15 & 0.05 & 0.97 \\
\hline $\mathbf{S i}$ & 0.93 & 0.09 & 0.16 & 0.11 & 0.18 & 0.03 & 0.95 \\
\hline $\mathbf{C a}$ & 0.86 & 0.16 & 0.13 & 0.27 & 0.27 & 0.09 & 0.94 \\
\hline $\mathbf{F e}$ & 0.83 & 0.22 & 0.21 & 0.38 & 0.17 & 0.16 & 0.99 \\
\hline $\mathbf{K}$ & 0.80 & 0.10 & 0.29 & 0.13 & 0.26 & 0.30 & 0.91 \\
\hline $\mathrm{Cr}$ & 0.73 & -0.05 & 0.28 & 0.33 & 0.03 & 0.13 & 0.74 \\
\hline $\mathbf{K}^{+}(\mathbf{I C})$ & 0.59 & 0.03 & 0.44 & 0.05 & 0.25 & 0.56 & 0.92 \\
\hline $\mathrm{Mg}^{2+}(\mathrm{IC})$ & 0.59 & 0.04 & 0.17 & -0.02 & 0.51 & 0.08 & 0.64 \\
\hline $\mathrm{SO}_{4}{ }^{2-}(\mathrm{IC})$ & 0.02 & 0.93 & -0.05 & 0.19 & 0.10 & 0.18 & 0.95 \\
\hline $\mathbf{S}$ & 0.10 & 0.89 & -0.06 & 0.32 & 0.18 & -0.06 & 0.95 \\
\hline $\mathbf{P}$ & 0.14 & 0.88 & 0.04 & 0.29 & 0.18 & -0.13 & 0.93 \\
\hline $\mathrm{NH}_{4}{ }^{+}(\mathrm{IC})$ & -0.08 & 0.88 & -0.07 & 0.18 & -0.10 & 0.29 & 0.91 \\
\hline V & 0.21 & 0.74 & 0.04 & 0.28 & 0.30 & -0.12 & 0.78 \\
\hline EBC & 0.10 & -0.04 & 0.89 & 0.15 & -0.16 & 0.10 & 0.86 \\
\hline $\mathbf{E C}$ & 0.26 & -0.21 & 0.88 & 0.12 & 0.05 & 0.10 & 0.92 \\
\hline OC & 0.49 & 0.07 & 0.80 & 0.02 & 0.16 & 0.07 & 0.92 \\
\hline $\mathbf{P M}_{2.5}$ & 0.40 & 0.42 & 0.74 & -0.04 & 0.08 & 0.13 & 0.90 \\
\hline $\mathrm{NO}_{3}^{-}(\mathrm{IC})$ & 0.30 & -0.19 & 0.50 & 0.02 & 0.37 & 0.46 & 0.72 \\
\hline $\mathbf{Z n}$ & 0.04 & 0.36 & 0.05 & 0.87 & 0.16 & 0.02 & 0.92 \\
\hline $\mathbf{P b}$ & 0.12 & 0.24 & 0.06 & 0.79 & 0.16 & 0.21 & 0.77 \\
\hline $\mathrm{Cu}$ & 0.48 & 0.15 & 0.30 & 0.71 & 0.12 & 0.14 & 0.88 \\
\hline $\mathbf{N i}$ & 0.15 & 0.44 & 0.05 & 0.69 & 0.11 & -0.05 & 0.71 \\
\hline Mn & 0.39 & 0.43 & 0.04 & 0.69 & 0.16 & 0.13 & 0.85 \\
\hline $\mathrm{Na}^{+}(\mathrm{IC})$ & 0.47 & 0.13 & 0.06 & 0.15 & 0.77 & 0.08 & 0.86 \\
\hline $\mathbf{N a}$ & 0.14 & 0.40 & -0.09 & 0.29 & 0.77 & -0.09 & 0.87 \\
\hline Cl & 0.19 & 0.31 & 0.01 & 0.28 & 0.76 & 0.02 & 0.79 \\
\hline $\mathrm{Cl}^{-}(\mathrm{IC})$ & 0.37 & -0.18 & 0.35 & 0.04 & 0.46 & 0.27 & 0.58 \\
\hline Acetato (IC) & 0.07 & 0.07 & 0.07 & 0.15 & -0.07 & 0.92 & 0.89 \\
\hline Oxalato (IC) & 0.41 & 0.37 & 0.31 & 0.08 & 0.08 & 0.60 & 0.77 \\
\hline Formiato (IC) & 0.49 & -0.10 & 0.52 & 0.10 & 0.18 & 0.59 & 0.90 \\
\hline Autovalor & 13.8 & 5.92 & 2.43 & 1.60 & 1.51 & 1.43 & Variância total \\
\hline Variância & $44.5 \%$ & $19.1 \%$ & $7.84 \%$ & $5.16 \%$ & 4.85 & $4.61 \%$ & $86.1 \%$ \\
\hline
\end{tabular}

Tabela 5-1 Matriz de factor loadings da análise de fatores principais para a estação IBP na fração fina. Foram determinados seis fatores estatisticamente significantes, explicando 87.3\% da variabilidade original. Os valores em negrito indicam as associações majoritárias. São apresentadas, também as comunalidades associadas às 31 variáveis entradas no modelo. $\mathrm{O}$ percentual explicado indica a razão entre a soma das atribuições e o valor medido. As componentes identificadas são (1) ressuspensão de solo, (2) aerossóis de sulfato e emissões industriais, (3) emissões veiculares, (4) emissões industriais, (5) aerossol marinho e (6) aerossol orgânico secundário. 
1. Ressuspensão de poeira do solo, dada a forte associação com os elementos $\mathrm{Al}$, $\mathrm{Si}, \mathrm{Ca}, \mathrm{Ti}, \mathrm{Fe}, \mathrm{K}, \mathrm{Mg}$ e outros.

2. Aerossóis secundários de sulfato de amônia $\left(\mathrm{NH}_{4}, \mathrm{SO}_{4}\right.$ e S). Este fator esta correlacionado com $\mathrm{Ni}, \mathrm{Mn}$ e $\mathrm{V}$, indicando também emissões de indústrias.

3. Emissões veiculares, caracterizadas pela associação com as componentes carbonáceas (OC, EC e EBC) e com o $\mathrm{PM}_{2.5}$.

4. Emissões industriais, associadas aos elementos $\mathrm{Zn}, \mathrm{Pb}, \mathrm{Cu}, \mathrm{Mn}$ e $\mathrm{Ni}$.

5. Partículas de aerossóis marinhos, associado com os elementos $\mathrm{Na}$ e $\mathrm{Cl}$.

6. O último fator é responsável pela maior parte da variabilidade dos compostos acetato, oxalato e formiato. Os mecanismos de formação destes ácidos orgânicos estão associados também à formação de aerossóis orgânicos secundários (SOA).

A APFA foi capaz de explicar, em média, 95\% das concentrações das variáveis medidas. Em particular, o modelo com seis fatores principais explicou 98\% da massa do particulado fino $\left(\mathrm{PM}_{2.5}\right)$ medido. Nota-se que em alguns casos foram modeladas concentrações negativas, o que não tem sentido físico, mas que refletem a estatística quando valores de concentração estão próximos de zero. A interpretação desses resultados é que a espécie em questão não possui variabilidade conjunta com aquele fator principal. Um aumento da concentração de material particulado na atmosfera atribuído àquela fonte de emissão implicará necessariamente numa redução da contribuição percentual desta espécie para o $\mathrm{PM}_{2.5}$ total medido no filtro.

Foi atribuída à componente veicular a responsabilidade por 68 e 79\% das emissões de $\mathrm{CO}$ e $\mathrm{NO}_{\mathrm{x}}$, respectivamente, bem como pela quase totalidade das concentrações de EC e EBC. É notável também, o grande percentual (entre 25 e 45\%) da massa dos elementos $\mathrm{Al}, \mathrm{Si}, \mathrm{Ca}$, Ti e Fe que é explicada por emissões veiculares. Uma vez que os automóveis são grandes responsáveis pela ressuspensão de poeira do solo, esses resultados são consistentes.

Observamos que é necessário realizar correções na atribuição quantitativa de fontes para a componente veicular devido ao fato de ser inevitável misturas de outras componentes que possuem co-variabilidade com a componente veicular. Como apresentado no capítulo 2 deste trabalho, de acordo com o inventário de emissões da CETESB, as fontes de emissão veicular 
têm um impacto correspondente a $37 \%$ das concentrações totais de sulfato na RMSP. Dessa forma, foi deslocada uma fração de $37 \%$ do $\mathrm{PM}_{2.5}$ (inicialmente atribuída ao fator de aerossóis de sulfato) para o $\mathrm{PM}_{2.5}$ da componente veicular (fator 3). Dada a elevada contribuição do perfil de emissão veicular para as concentrações de elementos como $\mathrm{Al}, \mathrm{Si}, \mathrm{Ca}$, Ti e Fe, foi calculada (conforme equação 4-2) a parcela de ressuspensão do solo atribuída a este fator, então subtraída da componente veicular e somada ao PM2.5 modelado no fator principal associado ao solo. Feitas estas correções, uma atribuição de fontes mais robusta pôde ser calculada, determinandose o impacto efetivo do setor veicular, incluindo sua parcela na componente de sulfato e sem a componente de solo ressuspendido. O resultado é exibido na figura 5-1.

A atribuição final de fontes do material particulado na fração fina para a estação do Ibirapuera mostra o impacto majoritário das fontes de emissão veicular, respondendo por $67 \%$ da massa do $\mathbf{P M}_{2.5}$. Aerossóis marinhos, orgânicos secundários e ressuspensão do solo contribuem com 4, 5 e 9\%, respectivamente. As componentes de aerossol de sulfato e emissões industriais fecham o balanço com $15 \%$ do total.

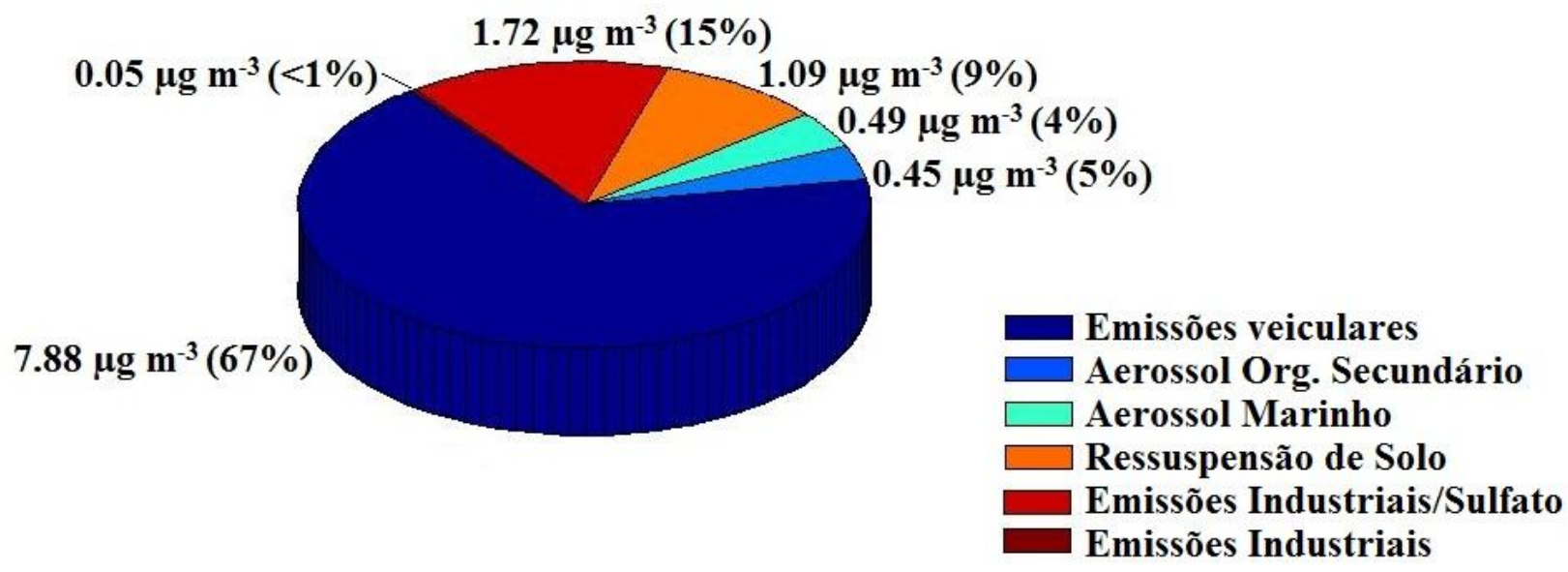

Figura 5-1 - Atribuição de fontes do material particulado fino para a estação amostradora IBP.

\subsection{Resultados da APFA aplicada aos dados da estação IFUSP (IFP)}

Foram coletados 101 filtros na estação de amostragem operada no IFUSP (IFP). A PFA foi empregada à base de dados para a discriminação das fontes utilizando-se das 29 variáveis que foram medidas em todas as amostras coletadas. As atribuições das variáveis com valores 
faltantes não incluídas na análise num primeiro momento foram estimadas posteriormente por regressão linear múltipla com os Factor Scores.

A tabela 5-2 apresenta os resultados da PFA exibindo os factor loadings obtidos após a rotação VARIMAX, onde os valores em negrito representam os loadings majoritários. Também é mostrada a porcentagem da variabilidade dos dados explicada por cada fator. Observa-se que os cinco primeiros fatores explicam $87,3 \%$ da variabilidade dos dados. A sexta componente apresentou um autovalor menor do que um (valor de 0.66), explicando apenas 2,3\% da variabilidade dos dados e, portanto, foram retidos na análise final cinco fatores para explicar a variabilidade do particulado fino na estação IFP.

Ainda na tabela 5-2, na última coluna, são exibidas também as comunalidades associadas a cada uma das variáveis. Para a maioria das variáveis, o modelo foi capaz de explicar em torno de $90 \%$ da variabilidade dos dados, que levando em conta a incerteza das análises e amostragem, que é da ordem de 10\%, é satisfatório. Cinco variáveis (V, Cr, Mn, Ni e oxalato) tiveram comunalidades abaixo de 0.8, mas ainda assim cerca de $75 \%$ da sua variabilidade foi explicada. Assim, a PFA resultando em cinco fatores para a estação IFP, pode ser considerada satisfatória. A única exceção, assim como no caso do IBP, foi a variável $\mathrm{Cl}^{-}$, cuja variabilidade explicada pelo modelo foi de apenas 68\%. Segundo Weaver and Foster (1954), uma possível explicação para a menor comunalidade encontrada para este elemento pode ser o deslocamento do $\mathrm{Cl}$ marinho na fração fina através da formação de $\mathrm{Na}_{2} \mathrm{SO}_{4}$ liberando $\mathrm{Cl}_{2}$ que, quando à temperatura ambiente, encontra-se na fase gasosa, sendo perdido na fase de aerossóis. Dessa forma, o cloro pode eventualmente ser removido parcialmente do material particulado, prejudicando sua quantificação na fase de particulado e, portanto, a determinação correta das suas fontes (Gerab, 1996).

Os cinco fatores, discriminados de acordo com sua estrutura, podem ser interpretados como se segue, através de alguns traçadores específicos:

1. O primeiro fator correlaciona-se com elementos característicos de ressuspensão de solo, como os elementos $\mathrm{Al}, \mathrm{Ti}, \mathrm{Si}, \mathrm{Ca}$ e Fe. Este fator tem também uma forte associação com o $\mathrm{PM}_{2.5}$ e mediana com o EBC, indicando também uma mistura 
com emissões veiculares. Observa-se que este termo é responsável por uma fração significativa $(52,4 \%)$ da variabilidade dos dados.

2. O segundo fator está associado principalmente com as variáveis $\mathrm{SO}_{4}{ }^{2-}, \mathrm{NH}_{4}{ }^{+} \mathrm{e} \mathrm{V}$, indicando a contribuição de aerossol inorgânico secundário de sulfato. Emissões industriais também podem ser associadas a esta componente, dada a associação com o Zn.

3. O fator 3 também está correlacionado com a variável $\mathrm{PM}_{2.5}$ e com o EBC, indicando impacto de emissões veiculares. Este fator tem associação em quantidades variáveis também com os elementos $\mathrm{Cu}, \mathrm{Cr}, \mathrm{Ni}, \mathrm{Pb}, \mathrm{Zn}$ e $\mathrm{Mn}$.

4. O quarto fator obtido a partir da PFA da fração fina indica o impacto de aerossol marinho, visto que este fator tem forte associação com $\mathrm{Na}$ e $\mathrm{Mg}$. Contudo, a variabilidade do elemento cloro foi pouco explicada por este fator, tanto para o $\mathrm{Cl}$ medido por XRF como por IC. Como discutido anteriormente, isso provavelmente é explicado pela liberação de $\mathrm{Cl}_{2}$ na fase gasosa, decorrente da formação de $\mathrm{Na}_{2} \mathrm{SO}_{4}$, removendo parte do $\mathrm{Cl}$ presente no material particulado. $\mathrm{O} \mathrm{Na}$ nesta condição não é perdido da fase particulada.

5. O quinto e último fator está associado aos compostos formiato, nitrato e oxalato e representa o impacto do aerossol orgânico secundário para a fração fina do material particulado.

Diferente do que foi observado na estação amostradora do Ibirapuera, a PFA com cinco fatores para o IFP conseguiu separar duas componentes veiculares distintas: o fator 1, com presença majoritária de elementos do solo e veiculares e também o fator 2. Este por sua vez tem associação maior com EBC, indicando possivelmente um impacto maior de veículos pesados movidos a diesel em comparação com o primeiro fator principal. A co-variabilidade da componente veicular com os elementos do solo é esperada, visto que os veículos são grandes responsáveis pela suspensão de poeira. 


\begin{tabular}{|c|c|c|c|c|c|c|}
\hline \multirow{2}{*}{ Espécie } & \multicolumn{5}{|c|}{ Fator Principal } & \multirow{2}{*}{ Comunalidades } \\
\hline & 1 & 2 & 3 & 4 & 5 & \\
\hline Al & 0.96 & -0.03 & 0.08 & -0.05 & 0.13 & 0.95 \\
\hline $\mathbf{T i}$ & 0.95 & 0.02 & 0.24 & -0.03 & 0.06 & 0.96 \\
\hline $\mathbf{S i}$ & 0.94 & 0.04 & 0.12 & -0.01 & 0.16 & 0.92 \\
\hline $\mathbf{C a}$ & 0.83 & 0.14 & 0.26 & 0.38 & 0.07 & 0.93 \\
\hline $\mathbf{K}$ & 0.82 & 0.10 & 0.45 & 0.08 & 0.10 & 0.90 \\
\hline $\mathrm{Ca}^{2+}(\mathrm{IC})$ & 0.82 & 0.15 & 0.23 & 0.40 & 0.11 & 0.92 \\
\hline $\mathbf{K}^{+}(\mathbf{I C})$ & 0.81 & 0.07 & 0.45 & 0.09 & 0.12 & 0.88 \\
\hline $\mathbf{F e}$ & 0.80 & 0.23 & 0.46 & 0.20 & 0.02 & 0.94 \\
\hline Cl & 0.62 & -0.09 & 0.48 & 0.36 & 0.30 & 0.84 \\
\hline PM2.5 & 0.60 & 0.50 & 0.56 & 0.12 & 0.15 & 0.96 \\
\hline $\mathrm{NH}_{4}^{+}(\mathrm{IC})$ & 0.02 & 0.95 & 0.15 & 0.14 & 0.10 & 0.95 \\
\hline $\mathrm{SO}_{4}{ }^{2-}(\mathrm{IC})$ & 0.02 & 0.93 & 0.14 & 0.27 & 0.12 & 0.96 \\
\hline $\mathbf{S}$ & 0.05 & 0.93 & 0.19 & 0.26 & 0.13 & 0.98 \\
\hline $\mathbf{P}$ & 0.05 & 0.92 & 0.17 & 0.25 & 0.16 & 0.97 \\
\hline $\mathbf{V}$ & 0.23 & 0.68 & 0.37 & 0.18 & 0.30 & 0.77 \\
\hline EBC & 0.45 & 0.05 & 0.81 & -0.06 & 0.12 & 0.87 \\
\hline $\mathrm{Cu}$ & 0.47 & 0.19 & 0.76 & 0.15 & 0.08 & 0.86 \\
\hline $\mathrm{Cr}$ & 0.33 & 0.30 & 0.73 & -0.03 & 0.10 & 0.74 \\
\hline $\mathbf{N i}$ & 0.26 & 0.36 & 0.67 & 0.14 & 0.25 & 0.72 \\
\hline $\mathbf{P b}$ & 0.30 & 0.35 & 0.63 & 0.46 & -0.04 & 0.81 \\
\hline $\mathbf{Z n}$ & 0.18 & 0.48 & 0.60 & 0.41 & 0.14 & 0.82 \\
\hline Mn & 0.50 & 0.36 & 0.57 & 0.29 & 0.00 & 0.80 \\
\hline $\mathrm{Mg}^{2+}(\mathrm{IC})$ & 0.27 & 0.24 & -0.01 & 0.88 & 0.14 & 0.92 \\
\hline $\mathrm{Na}^{+}(\mathrm{IC})$ & 0.05 & 0.37 & 0.14 & 0.87 & 0.20 & 0.95 \\
\hline $\mathbf{N a}$ & 0.03 & 0.40 & 0.18 & 0.85 & 0.18 & 0.94 \\
\hline Formiato (IC) & -0.04 & 0.21 & -0.20 & 0.08 & 0.88 & 0.87 \\
\hline $\mathrm{NO}_{3}^{-}(\mathrm{IC})$ & 0.20 & 0.20 & 0.31 & 0.27 & 0.75 & 0.82 \\
\hline $\mathrm{Cl}^{-}(\mathrm{IC})$ & 0.30 & 0.06 & 0.29 & 0.14 & 0.70 & 0.68 \\
\hline Oxalato (IC) & 0.26 & 0.47 & 0.25 & 0.10 & 0.59 & 0.71 \\
\hline Autovalor & 15.20 & 5.09 & 1.99 & 1.76 & 1.29 & Variância Total \\
\hline Variância & $52.4 \%$ & $17.5 \%$ & $6.85 \%$ & $6.05 \%$ & $4.46 \%$ & $87.3 \%$ \\
\hline
\end{tabular}

Tabela 5-2 Matriz de factor loadings da análise de fatores principais para a estação IFP na fração fina. Foram determinados cinco fatores estatisticamente significantes, explicando 87.3\% da variabilidade original. Os valores em negrito indicam as associações majoritárias. São apresentadas, também as comunalidades associadas às 29 variáveis entradas no modelo. As componentes identificadas são (1) ressuspensão de solo e emissões veiculares, (2) emissões industriais e de sulfato, (3) emissões veiculares, (4) aerossol marinho e (5) aerossol orgânico secundário. 
Resultados quantitativos foram obtidos através da APFA, onde se determinou a matriz dos "Absolute Principal Factor Scores" (APFS), contendo a variabilidade relativa de cada um dos cinco fatores retidos. Finalmente, a partir da regressão linear entre as variáveis medidas e os APFS foi possível estimar as contribuições médias de cada um dos cinco fatores retidas para as concentrações das variáveis. Na tabela A-2 são apresentados os resultados da APFA para todas as variáveis, incluindo agora também as variáveis com valores faltantes não determinados em todas as amostras analisadas.

O modelo foi capaz de explicar em torno de $95 \%$ das concentrações médias para a maioria das variáveis medidas. Novamente, observa-se que na APFA os fatores podem apresentar pequeno impacto negativo na concentração de algumas variáveis. Visto que nenhuma fonte pode emitir massa negativa, essa atribuição indica que a componente em questão não contribui para a concentração atmosférica daquela espécie ou composto, e o valor deve ser zero, dentro dos desvios experimentais.

As concentrações de $\mathrm{CO}$ e $\mathrm{NO}_{\mathrm{x}}$ explicadas pelo modelo (compostos cujas principais fontes são os processos de combustão) foram predominantemente associadas ao primeiro e ao terceiro fator, ressaltando que estes perfis sejam de fato provenientes de impacto veicular. $\mathrm{O}$ EBC explicado pelo modelo também se atribui majoritariamente a essas mesmas duas componentes.

Outro ponto importante relativo aos fatores associados ao impacto veicular é que estes se caracterizam por uma composição carbonácea totalmente distinta. A partir das concentrações absolutas discriminadas, observa-se que no primeiro fator a razão OC:EC é aproximadamente igual a 2.48, enquanto no fator 3, esse valor é de 0.93. Consistentemente, estudos em túneis reportam valores de OC:EC entre 1.5 e 2.4 para veículos leves e valores mais próximos de 0.5 em tuneis utilizados majoritariamente para veículos pesados movidos a diesel (Brito et al., 2013).

O modelo APFA conseguiu explicar $99 \%$ da massa do material particulado medido na fração fina na estação amostradora IFP, sendo que $90 \%$ desse valor foi atribuído às 
componentes 1,2 e 3 . A contribuição efetiva associada às emissões veiculares foi calculada a partir de uma nova atribuição das fontes, embasada em algumas considerações.

Levando em conta que o primeiro fator represente emissões veiculares somadas a ressuspensão de poeira do solo, é preciso particionar essas duas fontes subtraindo a contribuição efetivamente do solo, estimada pela equação 4-2, a partir das concentrações de Al, Si, Ca, Ti e Fe que foi atribuída a este fator. Removida esta fração, o restante da massa atribuída ao fator 1 deve ser somado à massa atribuída ao terceiro fator principal (emissões de veículos a diesel), juntamente com a fração da componente de sulfato estimada para o setor veicular (37\% do $\mathrm{PM}_{2.5}$ associado ao fator 2). A figura 5-2 apresenta a redistribuição das fontes do aerossol atmosférico na fração fina para a estação IFP, calculada como descrito acima.

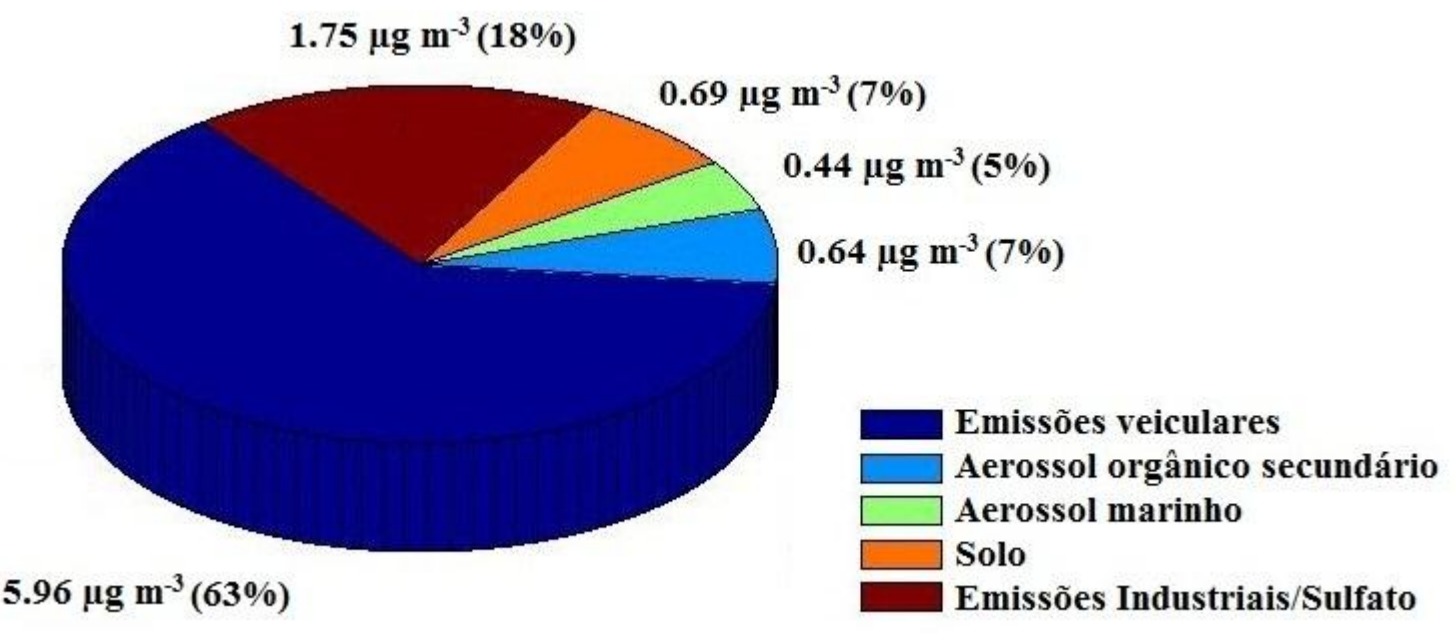

Figura 5-2 Atribuição de fontes para o material particulado fino na estação amostradora IFP.

A distribuição quantitativa de fontes do aerossol atmosférico na estação IFP recalculada mostra alto impacto de emissões veiculares, correspondendo a $63 \%$ do total de $\mathbf{P M}_{2.5}$. Nesta estação as emissões industriais e de sulfato respondem por $18 \%$ da massa do particulado fino, enquanto as contribuições de ressuspensão de poeira do solo, aerossol marinho e o impacto de aerossol orgânico secundário somam 19\% do total modelado.

\subsection{Resultados da APFA aplicada aos dados da estação Cerqueira César (FSP)}

Na estação amostradora de Cerqueira César (FSP) foi obtido um total de 100 amostras de material particulado fino, e foi empregada a PFA para identificação quantitativa de fontes. 
Foram utilizadas na análise 31 variáveis que, após a validação da base de dados, não apresentaram valores faltantes. Os resultados da análise de fatores em termos destes cinco fatores principais são mostrados na tabela 5-3.

\begin{tabular}{|c|c|c|c|c|c|c|}
\hline \multirow{2}{*}{ Espécie } & \multicolumn{5}{|c|}{ Fator Principal } & \multirow{2}{*}{ Comunalidades } \\
\hline & 1 & 2 & 3 & 4 & 5 & \\
\hline EBC & 0.89 & 0.14 & 0.16 & -0.02 & 0.20 & 0.88 \\
\hline EC & 0.88 & -0.02 & 0.17 & -0.08 & 0.16 & 0.84 \\
\hline $\mathrm{Cr}$ & 0.81 & 0.01 & 0.20 & -0.05 & 0.08 & 0.70 \\
\hline $\mathbf{K}$ & 0.77 & -0.03 & 0.49 & 0.14 & 0.15 & 0.88 \\
\hline $\mathbf{K}^{+}(\mathbf{I C})$ & 0.74 & -0.09 & 0.44 & 0.14 & 0.22 & 0.82 \\
\hline $\mathbf{C u}$ & 0.73 & -0.07 & 0.46 & -0.06 & 0.12 & 0.77 \\
\hline OC & 0.70 & 0.26 & 0.42 & -0.01 & 0.24 & 0.79 \\
\hline Mn & 0.70 & 0.34 & 0.39 & 0.20 & 0.08 & 0.80 \\
\hline $\mathbf{P b}$ & 0.67 & 0.49 & 0.05 & 0.37 & 0.05 & 0.84 \\
\hline $\mathbf{B r}$ & 0.64 & 0.15 & 0.23 & 0.44 & 0.23 & 0.74 \\
\hline PM2.5 & 0.64 & 0.60 & 0.35 & 0.11 & 0.19 & 0.94 \\
\hline $\mathbf{N i}$ & 0.61 & 0.46 & 0.08 & 0.19 & 0.31 & 0.72 \\
\hline $\mathbf{Z n}$ & 0.60 & 0.54 & -0.12 & 0.36 & 0.09 & 0.80 \\
\hline Oxalato (IC) & 0.55 & 0.46 & 0.36 & 0.11 & 0.27 & 0.73 \\
\hline $\mathbf{V}$ & 0.54 & 0.51 & 0.00 & 0.17 & 0.22 & 0.63 \\
\hline $\mathrm{NH}_{4}{ }^{+}(\mathrm{IC})$ & -0.03 & 0.97 & 0.04 & 0.03 & 0.02 & 0.94 \\
\hline $\mathrm{SO}_{4}^{2-}(\mathrm{IC})$ & 0.03 & 0.96 & 0.09 & 0.18 & 0.10 & 0.97 \\
\hline $\mathbf{S}$ & 0.06 & 0.95 & 0.10 & 0.19 & 0.07 & 0.97 \\
\hline $\mathbf{P}$ & 0.14 & 0.93 & 0.15 & 0.20 & 0.04 & 0.95 \\
\hline Si & 0.44 & 0.08 & 0.81 & 0.06 & 0.25 & 0.93 \\
\hline Al & 0.45 & -0.08 & 0.80 & 0.03 & 0.25 & 0.91 \\
\hline $\mathbf{C a}$ & 0.10 & 0.35 & 0.78 & 0.24 & 0.09 & 0.81 \\
\hline $\mathbf{T i}$ & 0.50 & -0.05 & 0.77 & 0.00 & 0.22 & 0.88 \\
\hline $\mathbf{F e}$ & 0.56 & 0.06 & 0.74 & -0.04 & -0.01 & 0.88 \\
\hline $\mathrm{Ca}^{2+}(\mathrm{IC})$ & 0.04 & 0.39 & 0.73 & 0.29 & 0.11 & 0.78 \\
\hline $\mathrm{Na}^{+}(\mathrm{IC})$ & 0.03 & 0.25 & 0.04 & 0.91 & 0.25 & 0.95 \\
\hline $\operatorname{Mg}^{2+}(\mathrm{IC})$ & -0.06 & 0.09 & 0.28 & 0.90 & 0.05 & 0.90 \\
\hline $\mathbf{N a}$ & 0.19 & 0.35 & -0.01 & 0.88 & 0.13 & 0.95 \\
\hline $\mathrm{NO}_{3}^{-}(\mathrm{IC})$ & 0.31 & 0.19 & 0.23 & 0.14 & 0.84 & 0.91 \\
\hline $\mathrm{Cl}^{-}(\mathrm{IC})$ & 0.17 & 0.03 & 0.15 & 0.36 & 0.74 & 0.74 \\
\hline Formiato (IC) & 0.44 & 0.17 & 0.31 & 0.03 & 0.72 & 0.84 \\
\hline Autovalor & 15.3 & 5.15 & 2.42 & 2.07 & 1.26 & Variância Total \\
\hline Variância & $49.3 \%$ & $16.6 \%$ & $7.8 \%$ & $6.7 \%$ & $4.1 \%$ & $84.5 \%$ \\
\hline
\end{tabular}

Tabela 5-3 Matriz de factor loadings da análise de fatores principais para a estação amostradora Cerqueira César na fração fina. Foram determinados cinco fatores estatisticamente significantes, explicando $84.5 \%$ da variabilidade original. Os valores em negrito indicam as associações majoritárias. São apresentadas, também as comunalidades associadas às 30 variáveis entradas no modelo. As componentes identificadas são (1) emissões veiculares e 
ressuspensão de solo, (2) emissões industriais e de sulfato, (3) ressuspensão de solo e emissões veiculares, (4) aerossol marinho e (5) aerossol orgânico secundário.

Após a rotação ortogonal dos autovetores, cinco fatores principais apresentaram autovalor maior que um e conseguiram explicar $84,5 \%$ da variabilidade. A possível inclusão de mais um fator principal foi descartada por representar apenas 2,5\% em termos da variância explicada.

Conforme apresentado na tabela 5-3, verifica-se que as comunalidades estão em torno de 0.85, para a maioria das variáveis, o que significa $85 \%$ da variabilidade explicada para cada variável. Os resultados da PFA, em termos dos factor loadings, também são exibidos nesta tabela. A partir das associações majoritárias com cada espécie medida, os fatores principais puderam ser interpretados como se segue:

1. O primeiro fator está associado principalmente com EBC e EC, além de OC e da massa do $\mathrm{PM}_{2.5}$, indicando o impacto veicular. Em menor escala, temos associações com os elementos $\mathrm{Al}, \mathrm{Si}, \mathrm{Ca}$, Ti e Fe indicando covariabilidade com ressuspensão de aerossóis de solo. Este fator é identificado como Veículos + Solo

2. Aerossol secundário com $\mathrm{SO}_{4}$ e $\mathrm{NH}_{4}$, além do $\mathrm{PM}_{2.5}$. Observamos também metais pesados, indicando contribuição industrial nesta componente.

3. O fator 3 tem associação majoritária com os traçadores de ressuspensão do solo, mas, em menor proporção, correlação com as variáveis OC e FPM. Este perfil de fonte será identificado como Solo + Veículos.

4. O quarto fator está associado com $\mathrm{Br}, \mathrm{Cl}$ e, sobretudo, $\mathrm{Na}$ e $\mathrm{Mg}$, indicando o impacto de aerossóis marinhos.

5. Finalmente, o último fator principal retido explica a formação de aerossóis orgânicos secundários, correlacionando-se aos compostos nitrato e formiato.

A APFA permite que sejam determinadas as responsabilidades de cada fator principal para a massa medida de cada variável. A técnica foi empregada para todas as espécies químicas, inclusive aquelas com valores faltantes. As atribuições quantitativas das fontes são apresentadas na tabela A-3, onde a porcentagem explicada indica a razão entre a soma das frações explicadas pelo modelo e o valor médio das medidas. 
Observa-se que, em média, 97\% das concentrações medidas foram explicadas pelo modelo com cinco fatores principais. Em particular, 99\% da massa do particulado fino, ou $\mathrm{PM}_{2.5}$, foram atribuídas às novas variáveis. No caso dos gases $\mathrm{CO}$ e $\mathrm{NOx}$, os fatores associados a emissões veiculares responderam por 93 e $94 \%$ do total medido, respectivamente.

Novamente, uma redistribuição de massa do PM2.5 foi empregada, a fim de obter o impacto efetivo do setor veicular. As duas componentes associadas a emissões veiculares e poeira do solo podem ser separadas, calculando-se a contribuição dos óxidos de Al, Si, Ca, Ti e $\mathrm{Fe}$, a partir da equação 4-2, em cada uma delas. As quantidades subtraídas compõem a fração de solo do $\mathrm{PM}_{2.5}$, enquanto o restante representa o impacto veicular. Por fim, $37 \%$ da contribuição da componente de sulfato devem ser redistribuídos para o setor de veículos. A atribuição final de fontes (Figura 5-3) mostra novamente impacto majoritário do setor veicular. No caso da FSP, $60 \%$ do material particulado fino foi associado às emissões veiculares. Emissões industriais e aerossóis de sulfato contribuem para $21 \%$ do $\mathrm{PM}_{2.5}$, seguidos de ressuspensão do solo, com 12\%, e finalmente do impacto de aerossóis marinhos e aerossóis orgânicos secundários (SOA), com 5 e $2 \%$, respectivamente.

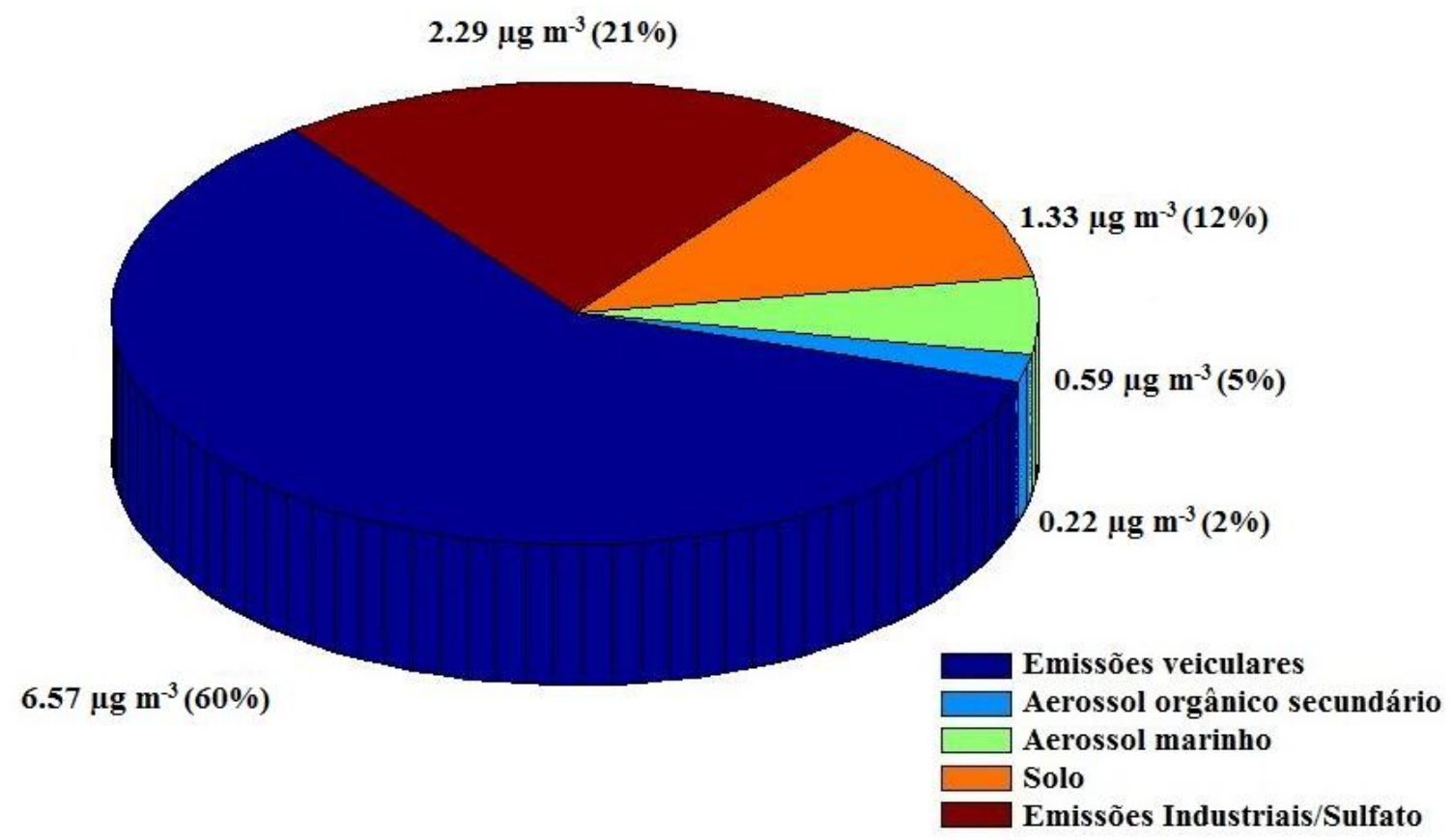

Figura 5-3 Atribuição final de fontes do material particulado fino para a estação amostradora Cerqueira César. 


\subsection{Compilação dos resultados obtidos na quantificação de fontes em SP}

Conforme apresentado na tabela 5-4, os valores obtidos na atribuição de fontes de PM2.5 foram muito próximos nas três estações amostradoras analisadas. A consistência desses resultados indica um aerossol com composição e impacto bastante similares na região metropolitana de São Paulo (RMSP).

\begin{tabular}{c|ccccc}
\hline $\begin{array}{c}\text { Estação } \\
\text { amostradora }\end{array}$ & $\begin{array}{c}\text { Emissões } \\
\text { Veiculares }\end{array}$ & $\begin{array}{c}\text { Sulfato + } \\
\text { Indústrias }\end{array}$ & $\begin{array}{c}\text { Ressuspensão } \\
\text { de Solo }\end{array}$ & $\begin{array}{c}\text { Aerossol } \\
\text { Marinho }\end{array}$ & $\begin{array}{c}\text { Aerossol Org. } \\
\text { Secundário }\end{array}$ \\
\hline Ibirapuera & $67 \%$ & $15 \%$ & $9 \%$ & $4 \%$ & $5 \%$ \\
IFUSP & $63 \%$ & $18 \%$ & $7 \%$ & $5 \%$ & $7 \%$ \\
C. César & $60 \%$ & $21 \%$ & $12 \%$ & $5 \%$ & $2 \%$ \\
Média & $\mathbf{6 3 \%}$ & $\mathbf{1 8 \%}$ & $\mathbf{9 \%}$ & $\mathbf{5 \%}$ & $\mathbf{5 \%}$ \\
\hline
\end{tabular}

Tabela 5-4 - Compilação geral dos resultados obtidos para a atribuição de fontes de $\mathrm{PM}_{2.5}$ nas estações amostradoras do Ibirapuera, IFUSP e Cerqueira César.

Considerando-se a média das três estações, o impacto do setor veicular foi estimado em 63\% para o $\mathrm{PM}_{2.5}$, sendo esta a componente mais expressiva em termos de emissões. Quanto a componente de emissões industriais e de sulfatos, observou-se um impacto médio de 18\% para o material particulado. Juntas, estas duas componentes explicaram mais de $80 \%$ das concentrações de aerossóis atmosféricos na fração fina para as três estações amostradoras. Finalmente, as fontes de material particulado associadas a ressuspensão de solo, aerossóis marinhos e a formação de aerossóis orgânicos secundários representam juntas um impacto da ordem de $20 \%$ para o $\mathrm{PM}_{2.5}$, sendo que individualmente estas representam 9\%, 5\% e 5\%, respectivamente. 


\subsection{Resultados da APFA aplicada ao conjunto de dados das três estações amostradoras (IFUSP, Cerqueira César e Ibirapuera)}

Foram amostrados, entre agosto de 2011 e janeiro de 2014, cerca de cem filtros em cada uma das quatro estações (IFP, FSP, CGH e FSP). Estas amostras compõe uma imensa base de dados de material particulado atmosférico da Região Metropolitana de São Paulo. Devido às altas concentrações, ocorreram frequentes entupimentos nos filtros no caso da estação de CGH, tornando impossível a separação do material particulado nas frações fina e grossa. Contudo, os filtros das demais três estações foram todos utilizados para a identificação quantitativa de fontes através do uso do modelo receptor.

A análise de fatores principais (PFA) foi aplicada ao conjunto de dados da fração fina das três estações. Após a validação da extensa base de dados, correção de eventuais outliers e estimativa de valores faltantes, 32 variáveis foram entradas no modelo. Na tabela A-4 são apresentados os resultados da análise de fatores, resultando em cinco fatores principais, capazes de explicar $80 \%$ da variabilidade dos dados. Observa-se que as variáveis V, Cr e, em especial, $\mathrm{Cl}^{-}$, tiveram menos de $65 \%$ da sua variabilidade explicada, mas, ainda assim, as comunalidades estiveram, em geral, em torno de 0.8. A partir das associações majoritárias entre os fatores principais e cada espécie química ou composto, foi possível discriminá-los como:

1. O primeiro fator se associa principalmente com os elementos traçadores de ressuspensão de solo, mas também com o $\mathrm{PM}_{2.5}$ e com $\mathrm{OC}$, indicando impacto veicular. Esse fator corresponde à variabilidade conjunta de emissões veiculares e solo.

2. Associado majoritariamente com $\mathrm{SO}_{4}, \mathrm{NH}_{4}, \mathrm{~V}, \mathrm{P}$, além dos elementos $\mathrm{Mn}$, $\mathrm{Ni}, \mathrm{Pb}, \mathrm{Cr}$ e $\mathrm{Zn}$, este fator representa as emissões industriais e de sulfato.

3. O terceiro fator principal é marcado pela presença do $\mathrm{PM}_{2.5}$ e $\mathrm{OC}$, sendo de impacto veicular. Este perfil veicular tem associação majoritária com EC e EBC, em comparação ao primeiro fator principal, indicando maior impacto de veículos pesados.

4. O quarto fator, assim como na análise das estações separadamente, tem a presença de $\mathrm{Na}, \mathrm{Cl}$ e $\mathrm{Mg}$, isto é, aerossóis marinhos. 
5. Por fim, a quinta componente corresponde a aerossóis orgânicos secundários, associada predominantemente aos compostos acetato, formiato, oxalato e nitrato.

A aplicação da APFA forneceu resultados quantitativos sobre as contribuições de cada um dos fatores principais separados pelo modelo para a concentração das variáveis medidas. Na tabela A-5 são exibidos os resultados da APFA, incluindo todas as variáveis medidas. Observase novamente que as fontes de impacto veicular juntas são responsáveis por cerca de $90 \%$ das concentrações de NOx e CO. Na comparação entre o total modelado e a concentração observada, a análise foi capaz de explicar em torno de $99 \%$ da média medida para todas as variáveis, inclusive do $\mathrm{PM}_{2.5}$.

Novamente, foi feita uma redistribuição da massa atribuída a cada fator principal a fim de determinar o impacto efetivo de cada setor. A contribuição de aerossóis oriundos de ressuspensão de poeira do solo é determinada a partir das concentrações dos elementos $\mathrm{Al}, \mathrm{Si}$, $\mathrm{Ca}$, Ti e Fe modeladas na primeira componente. Subtraída a massa atribuída à componente solo, a contribuição veicular total deve-se a soma das componentes 1 e 3 à fração da componente sulfato atribuída a este setor (37\%). Feitas essas considerações, a figura 5-4 apresenta a distribuição final das fontes de aerossóis atmosféricos na RMSP para o $\mathrm{PM}_{2.5}$.

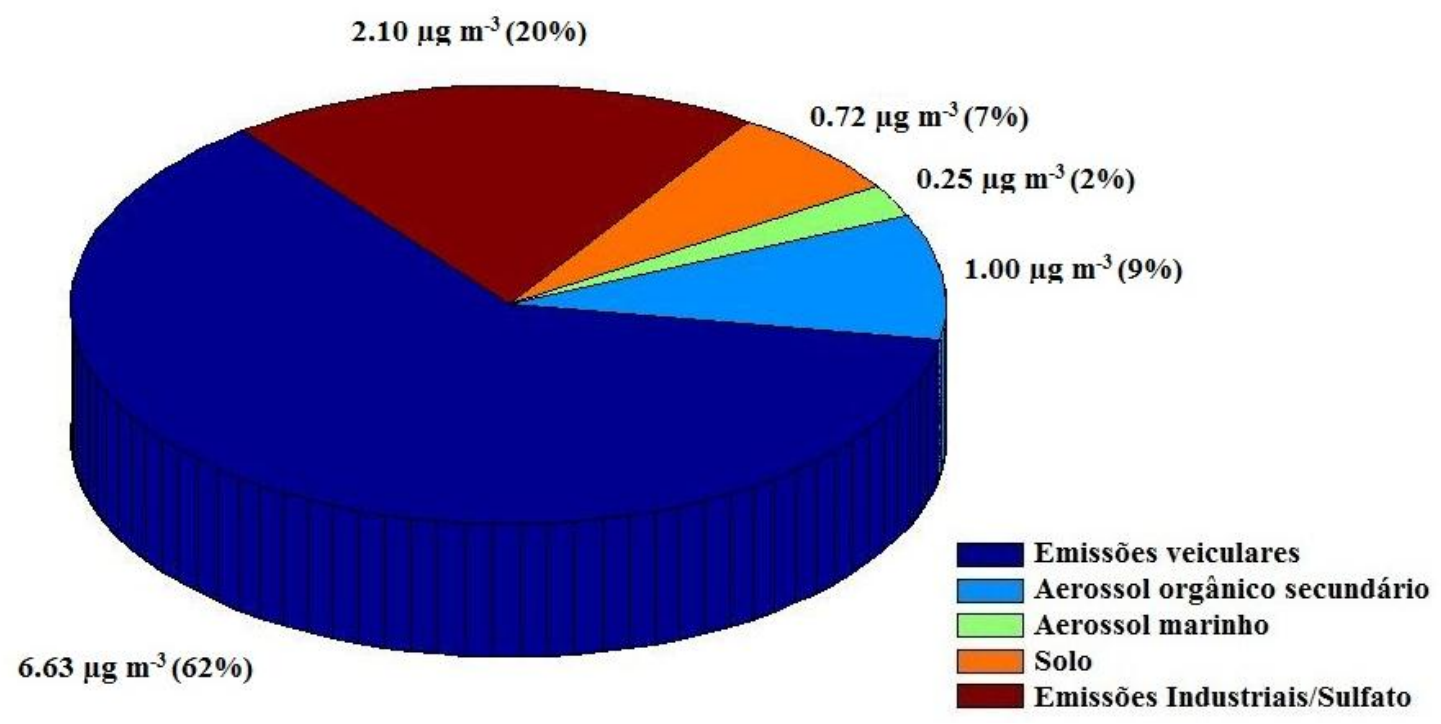

Figura 5-4 Atribuição final de fontes do material particulado fino para o conjunto de dados das estações IFUSP, Cerqueira César e Ibirapuera. 
Em consistência com os resultados obtidos na análise individual de cada estação, a PFA aplicada à base de dados como um todo associa o material particulado fino majoritariamente às emissões veiculares, respondendo por $62 \%$ do total. Emissões industriais e de aerossóis de sulfato tem um impacto de $20 \%$, enquanto SOA, ressuspensão do solo e aerossóis marinhos, foram responsabilizados por 9,7 e $2 \%$ do total.

O impacto de cada um dos fatores principais na concentração de material particulado ou de qualquer elemento/composto para cada amostra individualmente pode ser calculado a partir da equação 3-7. Utilizando novamente os critérios para redistribuição da massa, foi calculado o impacto efetivo das cinco fontes de aerossóis atmosféricos no conjunto dos filtros das estações Ibirapuera, IFUSP e Cerqueira César. As figuras 5-5 a 5-9 mostram a série temporal das concentrações de $\mathrm{PM}_{2.5}$ atribuídas a essas fontes durante todo o período de amostragem do projeto.

\section{Série temporal da componente de emissões veiculares}

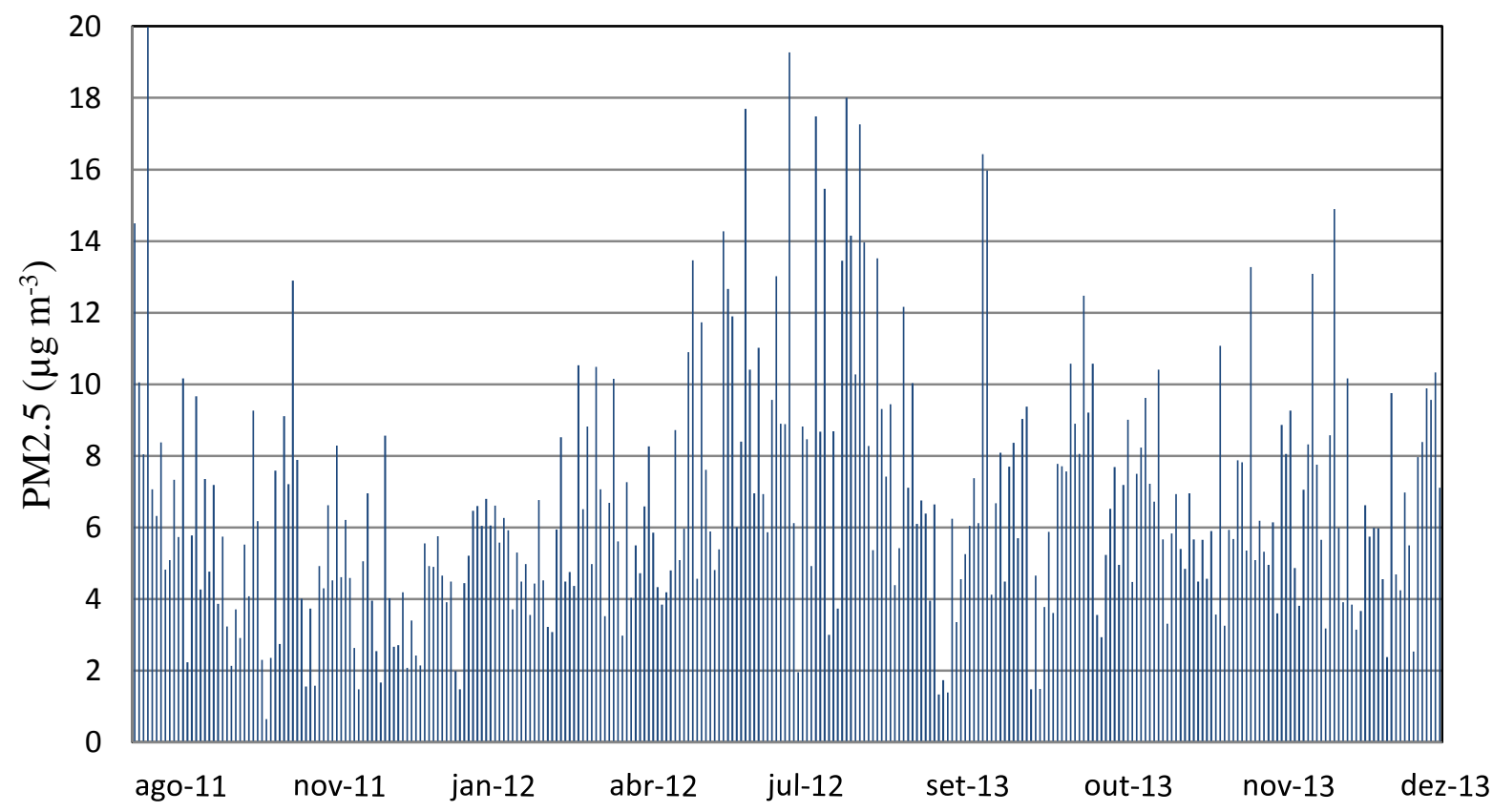

Figura 5-5 - Série temporal das concentrações de $\mathrm{PM}_{2.5}$ atribuídas às emissões veiculares na APFA com cinco fatores para o conjunto de dados das estações IFP, FSP e IBP no período de agosto de 2011 a janeiro de 2014. 
Série temporal da componente de ressuspensão de solo

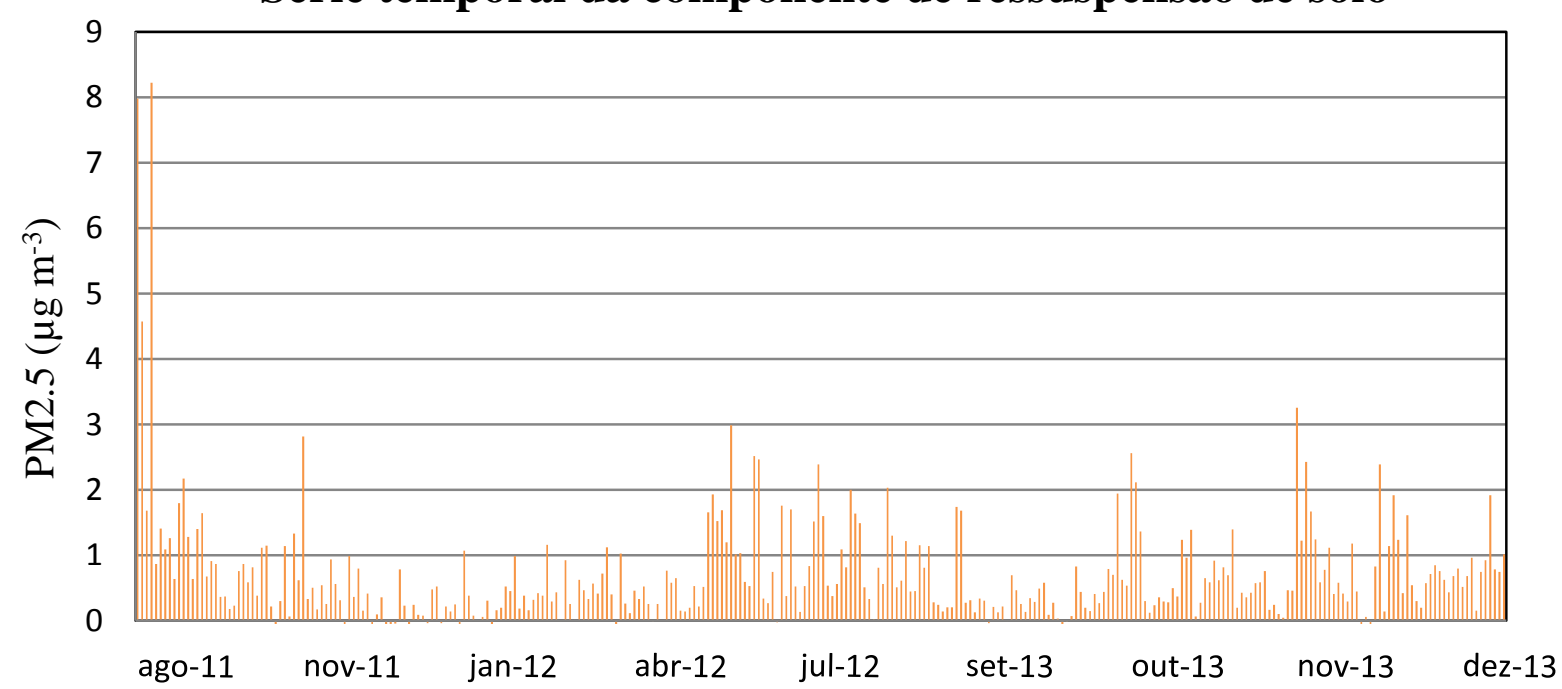

Figura 5-6 - Série temporal das concentrações de $\mathrm{PM}_{2.5}$ atribuídas à ressuspensão de poeira do solo na APFA com cinco fatores para o conjunto de dados das estações IFP, FSP e IBP no período de agosto de 2011 a janeiro de 2014.

Série temporal da componente de sulfato/emissões industriais

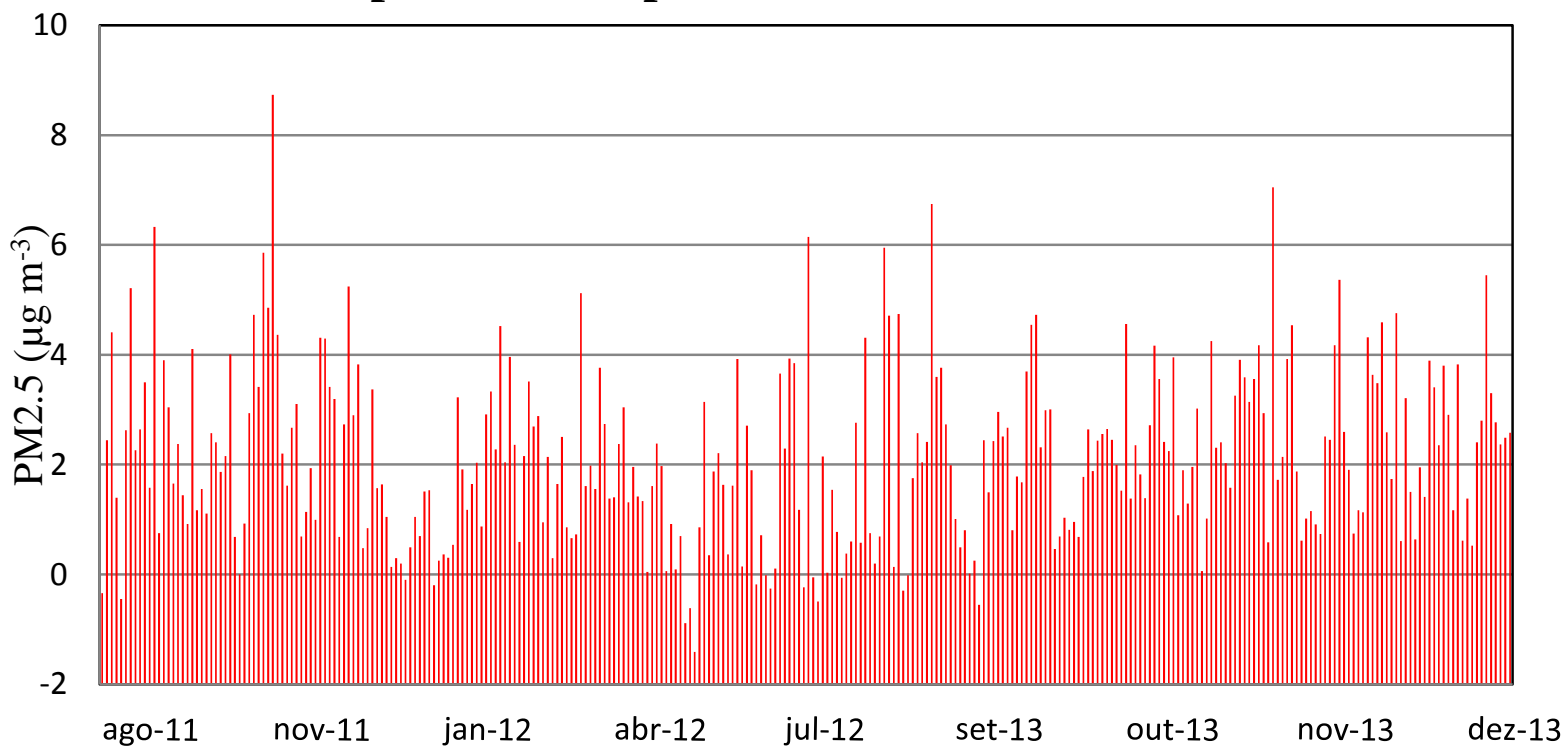

Figura 5-7 - Série temporal das concentrações de $\mathrm{PM}_{2.5}$ atribuídas a aerossóis de sulfato/emissões industriais na APFA com cinco fatores para o conjunto de dados das estações IFP, FSP e IBP no período de agosto de 2011 a janeiro de 2014. 


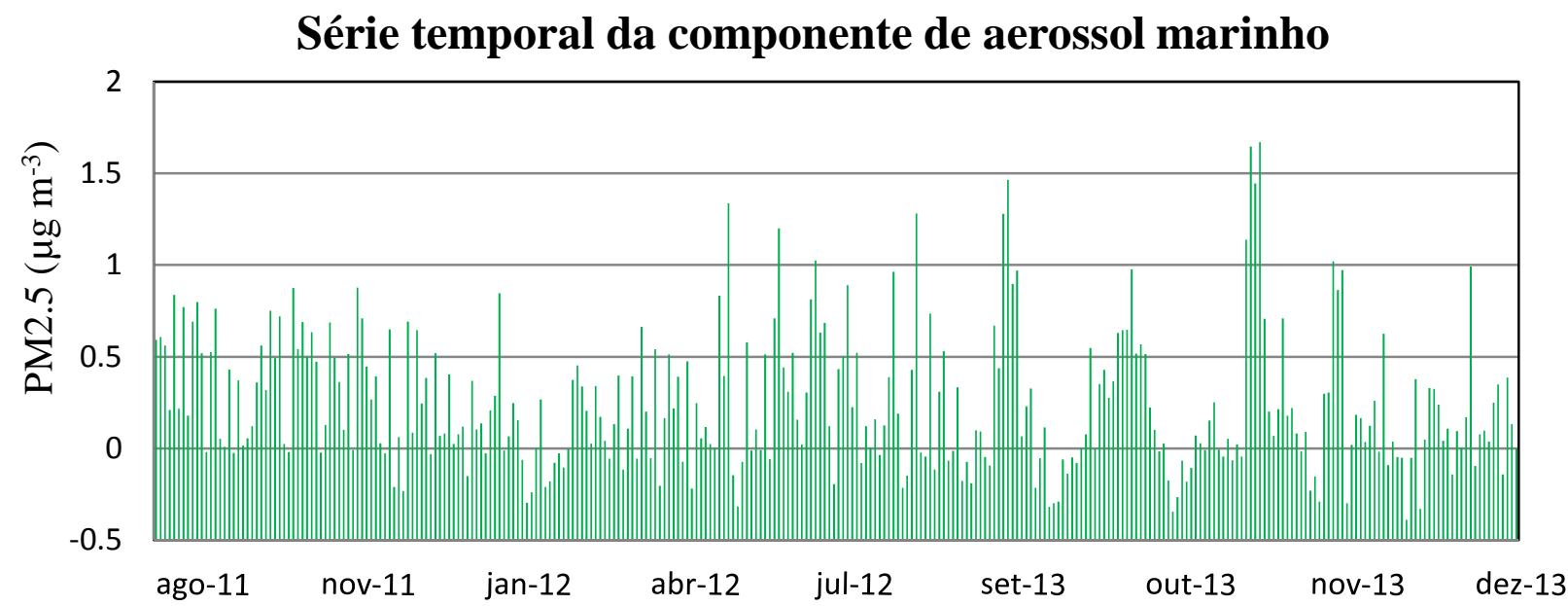

Figura 5-8 - Série temporal das concentrações de $\mathrm{PM}_{2.5}$ atribuídas ao aerossol marinho na APFA com cinco fatores para o conjunto de dados das estações IFP, FSP e IBP no período de agosto de 2011 a janeiro de 2014.

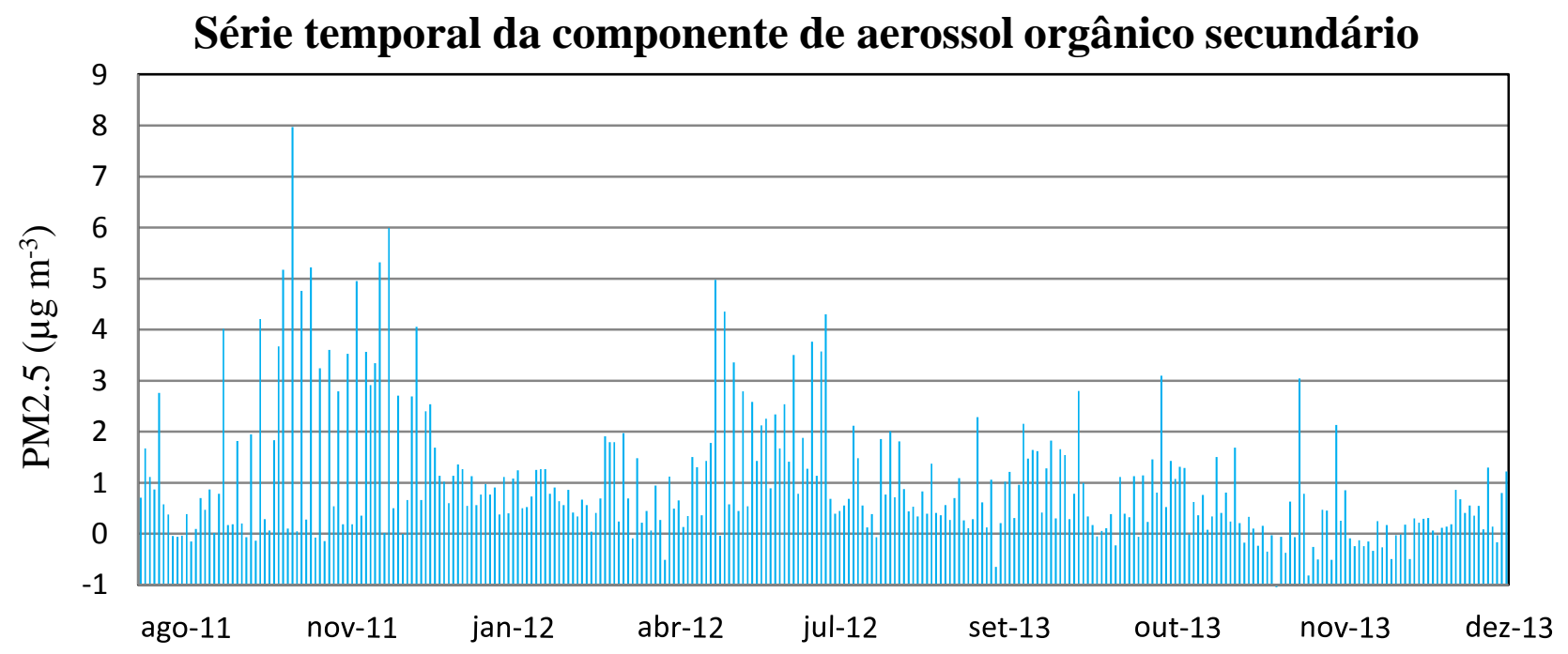

Figura 5-9 - Série temporal das concentrações de $\mathrm{PM}_{2.5}$ atribuídas a aerossóis orgânicos secundários na APFA com cinco fatores para o conjunto de dados das estações IFP, FSP e IBP no período de agosto de 2011 a janeiro de 2014.

É possível verificar um perfil sazonal nas séries temporais das concentrações de $\mathrm{PM}_{2.5}$ atribuídas aos fatores principais de emissão veicular, ressuspensão de poeira do solo e aerossol orgânico secundário, com concentrações mais altas no período de inverno em relação aos meses de verão. Os fatores de emissão industrial e aerossol marinho apresentam bastante variabilidade 
ao longo de toda a série temporal não representando um perfil característico. A figura 5-10 mostra a média das contribuições de cada uma dessas componentes discriminada entre os períodos de inverno (Maio, junho, julho e agosto) e verão (novembro, dezembro, janeiro e Fevereiro).

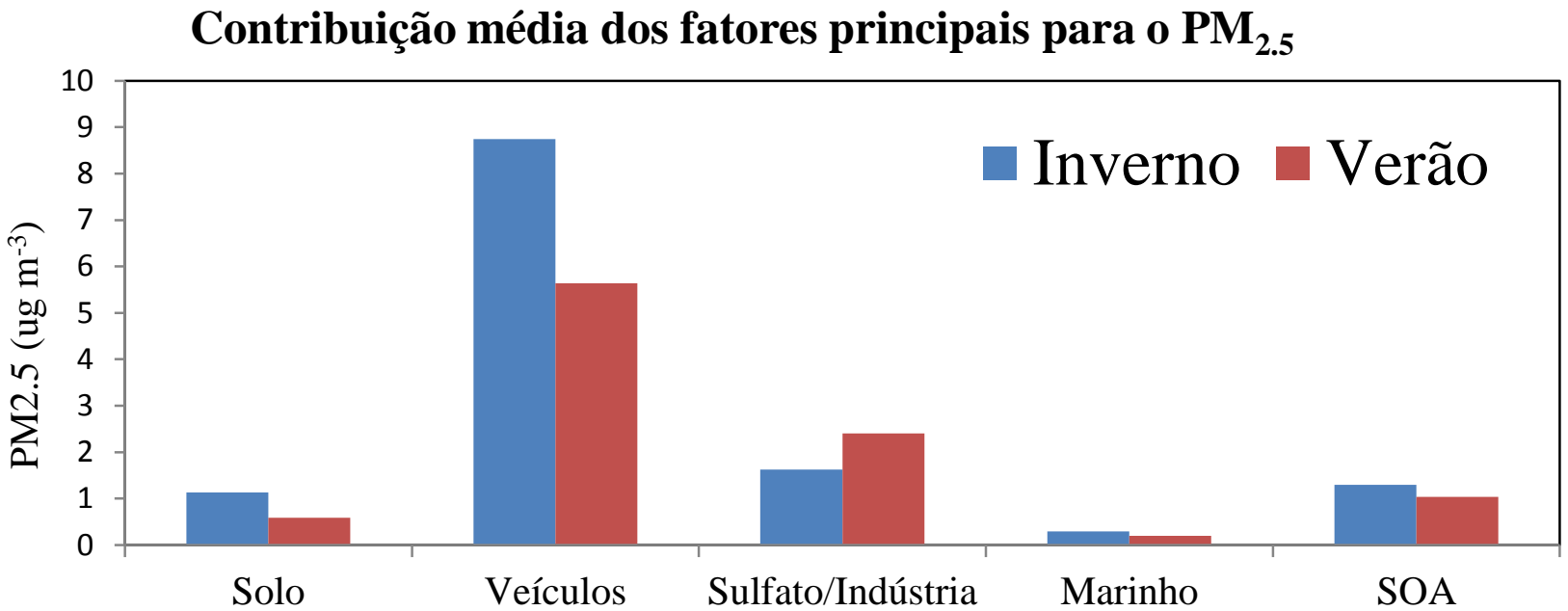

Figura 5-10 - Contribuição média dos cinco fatores principais para a concentração de material particulado fino referente ao conjunto de dados das estações IBP, FSP e IFP, para os meses de inverno (Maio, Junho, Julho e Agosto) e verão (Novembro, Dezembro, Janeiro e Fevereiro).

\subsection{Resultados dos modelos receptores aplicados às frações carbonáceas}

A análise termo-óptica (TOA), empregada para a quantificação do material carbonáceo nos filtros de quartzo, fornece, como discutido na seção 3.3.4, diferentes frações de OC e EC, distintas quanto ao seu comportamento térmico. Para caracterizar essas componentes os modelos receptores foram aplicados ao conjunto de dados das estações amostradoras IFP, FSP e IBP. Além das nove frações carbonáceas foram utilizados, novamente, os compostos iônicos e elementares, e as concentrações de EBC e PM2.5, como traçadores.

A análise de fatores principais (PFA) resultou em seis fatores estatisticamente significantes capazes de explicar $81 \%$ da variabilidade dos dados. Esses resultados são apresentados na tabela 5-5. Observa-se que, com seis fatores principais, as comunalidades estiveram em torno de 0.8 , à exceção do elemento $\mathrm{Cl}$, com valores acima de 0.7. A partir das associações majoritárias, valores em negrito, essas fatores puderam ser discriminados como: 
1. Fator associado ao $\mathrm{PM}_{2.5}$ e EBC, indicando impacto de emissões veiculares. Correlaciona-se com todas as frações de carbono, exceto a componente EC4, indicando que a maior parte da matéria carbonácea seja, de fato, emitida primariamente na forma de fuligem em processos de combustão em veículos.

2. Este fator esta associado aos elementos de poeira do solo: $\mathrm{Al}, \mathrm{Si}, \mathrm{Ca}, \mathrm{Ti}, \mathrm{Fe}$, etc. Dentre as frações carbonáceas, apenas a componente OC3 tem impacto neste fator.

3. Fator associado a aerossóis inorgânicos secundários de sulfato de amônia. Alta correlação com elementos como $\mathrm{V}$ e $\mathrm{Ni}$, traçadores da queima de óleo combustível, juntamente com $\mathrm{Zn}$ e Mn indicam o impacto de emissões industriais. Uma questão importante relativa a este fator é a sua forte correlação com a fração de carbono pirolítico.

4. Componente de partículas de aerossóis marinhos, associada majoritariamente com os elementos $\mathrm{Na}, \mathrm{Cl}$ e $\mathrm{Mg}$. Não esta associada a nenhuma das frações carbonáceas, como esperado.

5. Este fator explica a maior parte da variabilidade da componente de EC4 e dos elementos $\mathrm{Mn}$ e $\mathrm{Cu}$. Não foi possível identificar a origem deste fator principal.

6. Associação majoritária com ácidos orgânicos (acetato e formiato), além de nitrato e oxalato, em menor escala. Representa a formação de aerossol orgânico secundário.

A contribuição absoluta dos fatores principais para cada uma das frações carbonáceas foi obtida através da regressão linear entre as variáveis medidas e os APFS. A figura 5-11 mostra esses resultados. 


\begin{tabular}{|c|c|c|c|c|c|c|c|}
\hline \multirow{2}{*}{ Espécie } & \multicolumn{6}{|c|}{ Fator principal } & \multirow{2}{*}{ Comunalidades } \\
\hline & 1 & 2 & 3 & 4 & 5 & 6 & \\
\hline OC2 & 0.90 & 0.27 & 0.09 & 0.06 & 0.09 & 0.15 & 0.95 \\
\hline EC2 & 0.90 & 0.21 & 0.12 & 0.16 & -0.12 & 0.06 & 0.93 \\
\hline $\mathbf{E C}$ & 0.88 & 0.08 & -0.09 & 0.09 & 0.32 & 0.12 & 0.90 \\
\hline $\mathbf{O C}$ & 0.86 & 0.40 & 0.18 & 0.05 & -0.05 & 0.11 & 0.95 \\
\hline OC3 & 0.84 & 0.42 & -0.14 & 0.08 & 0.10 & 0.09 & 0.92 \\
\hline EC3 & 0.83 & 0.08 & 0.09 & 0.01 & 0.40 & 0.05 & 0.87 \\
\hline OC4 & 0.79 & 0.32 & 0.02 & 0.04 & 0.37 & 0.09 & 0.92 \\
\hline EC1 & 0.83 & 0.36 & 0.11 & 0.14 & -0.24 & 0.09 & 0.93 \\
\hline OC1 & 0.78 & 0.13 & 0.07 & 0.03 & 0.16 & 0.31 & 0.81 \\
\hline EBC & 0.80 & 0.13 & 0.10 & 0.11 & 0.38 & 0.07 & 0.83 \\
\hline PC & 0.69 & 0.35 & 0.46 & 0.02 & -0.27 & 0.05 & 0.89 \\
\hline $\mathbf{P M}_{2.5}$ & 0.63 & 0.40 & 0.52 & 0.12 & 0.09 & 0.08 & 0.86 \\
\hline Al & 0.24 & 0.92 & 0.03 & 0.03 & -0.09 & 0.04 & 0.93 \\
\hline Ti & 0.28 & 0.92 & 0.05 & 0.02 & 0.01 & 0.04 & 0.93 \\
\hline $\mathbf{S i}$ & 0.27 & 0.90 & 0.09 & 0.08 & 0.02 & 0.08 & 0.91 \\
\hline $\mathbf{C a}$ & 0.18 & 0.80 & 0.23 & 0.24 & 0.24 & 0.07 & 0.86 \\
\hline $\mathrm{Ca}^{+}(\mathrm{IC})$ & 0.20 & 0.77 & 0.22 & 0.23 & 0.17 & 0.14 & 0.82 \\
\hline $\mathbf{F e}$ & 0.35 & 0.73 & 0.22 & 0.13 & 0.44 & 0.02 & 0.91 \\
\hline $\mathbf{K}$ & 0.51 & 0.72 & 0.10 & 0.19 & 0.13 & 0.12 & 0.86 \\
\hline $\mathbf{K}^{+}(\mathbf{I C})$ & 0.55 & 0.64 & 0.04 & 0.18 & 0.05 & 0.20 & 0.79 \\
\hline $\mathbf{M g}^{2+}(\mathrm{IC})$ & 0.00 & 0.59 & 0.10 & 0.55 & -0.21 & 0.02 & 0.77 \\
\hline $\mathrm{Cr}$ & 0.44 & 0.49 & 0.12 & 0.14 & 0.37 & 0.11 & 0.71 \\
\hline $\mathrm{Cl}^{-}(\mathrm{IC})$ & 0.25 & 0.48 & -0.06 & 0.26 & -0.29 & 0.19 & 0.48 \\
\hline $\mathrm{SO}_{4}^{2-}(\mathrm{IC})$ & -0.03 & 0.07 & 0.96 & 0.12 & -0.02 & 0.08 & 0.96 \\
\hline $\mathbf{S}$ & 0.00 & 0.08 & 0.96 & 0.17 & 0.03 & 0.05 & 0.96 \\
\hline $\mathbf{P}$ & 0.05 & 0.12 & 0.94 & 0.17 & -0.03 & 0.03 & 0.94 \\
\hline $\mathrm{NH}_{4}^{+}(\mathrm{IC})$ & -0.04 & -0.01 & 0.94 & -0.05 & 0.07 & 0.10 & 0.93 \\
\hline V & 0.21 & 0.17 & 0.69 & 0.28 & 0.06 & 0.08 & 0.65 \\
\hline Zn & 0.22 & 0.06 & 0.56 & 0.53 & 0.37 & 0.01 & 0.83 \\
\hline $\mathbf{N i}$ & 0.31 & 0.11 & 0.51 & 0.38 & 0.37 & 0.12 & 0.72 \\
\hline $\mathbf{N a}$ & -0.02 & 0.12 & 0.43 & 0.81 & -0.09 & 0.09 & 0.89 \\
\hline $\mathrm{Na}^{+}(\mathrm{IC})$ & 0.00 & 0.38 & 0.28 & 0.76 & -0.27 & 0.12 & 0.91 \\
\hline Cl & 0.35 & 0.23 & 0.11 & 0.63 & 0.20 & 0.13 & 0.65 \\
\hline $\mathbf{P b}$ & 0.31 & 0.14 & 0.49 & 0.51 & 0.34 & 0.00 & 0.76 \\
\hline EC4 & 0.15 & -0.02 & 0.01 & -0.18 & 0.78 & -0.04 & 0.85 \\
\hline $\mathbf{C u}$ & 0.45 & 0.37 & 0.16 & 0.23 & 0.60 & 0.01 & 0.80 \\
\hline Mn & 0.28 & 0.39 & 0.48 & 0.33 & 0.48 & 0.02 & 0.83 \\
\hline Acetato (IC) & 0.18 & 0.01 & 0.11 & 0.02 & 0.07 & 0.90 & 0.86 \\
\hline Formiato (IC) & 0.12 & 0.12 & 0.10 & 0.05 & -0.13 & 0.89 & 0.86 \\
\hline $\mathrm{NO}_{3}^{-}(\mathrm{IC})$ & 0.36 & 0.27 & 0.07 & 0.29 & 0.07 & 0.62 & 0.68 \\
\hline Oxalato (IC) & 0.35 & 0.36 & 0.45 & 0.11 & 0.06 & 0.47 & 0.70 \\
\hline Autovalor & 18.3 & 5.71 & 3.64 & 2.48 & 1.76 & 1.63 & Variação total \\
\hline Variância & $44.8 \%$ & $13.9 \%$ & $8.89 \%$ & $6.05 \%$ & $4.30 \%$ & $3.97 \%$ & $81.9 \%$ \\
\hline
\end{tabular}

Tabela 5-5 - Matriz de factor loadings da análise de fatores principais para o conjunto de dados das estações amostradoras IBP, FSP e IFP na fração fina, incluindo as frações carbonáceas discriminadas. Foram determinadas seis componentes estatisticamente significantes, explicando $81.9 \%$ da variabilidade original. Os valores em negrito indicam as associações majoritárias. São apresentadas, também as comunalidades associadas às 31 variáveis entradas no modelo. 


\section{Quantificação de fontes do material carbonáceo}
- Aer. Org. Secundário
Não identificado
- Aerossol marinho
- Sulfato + Indústrias
Ressuspensão de solo
- Emissões veiculares

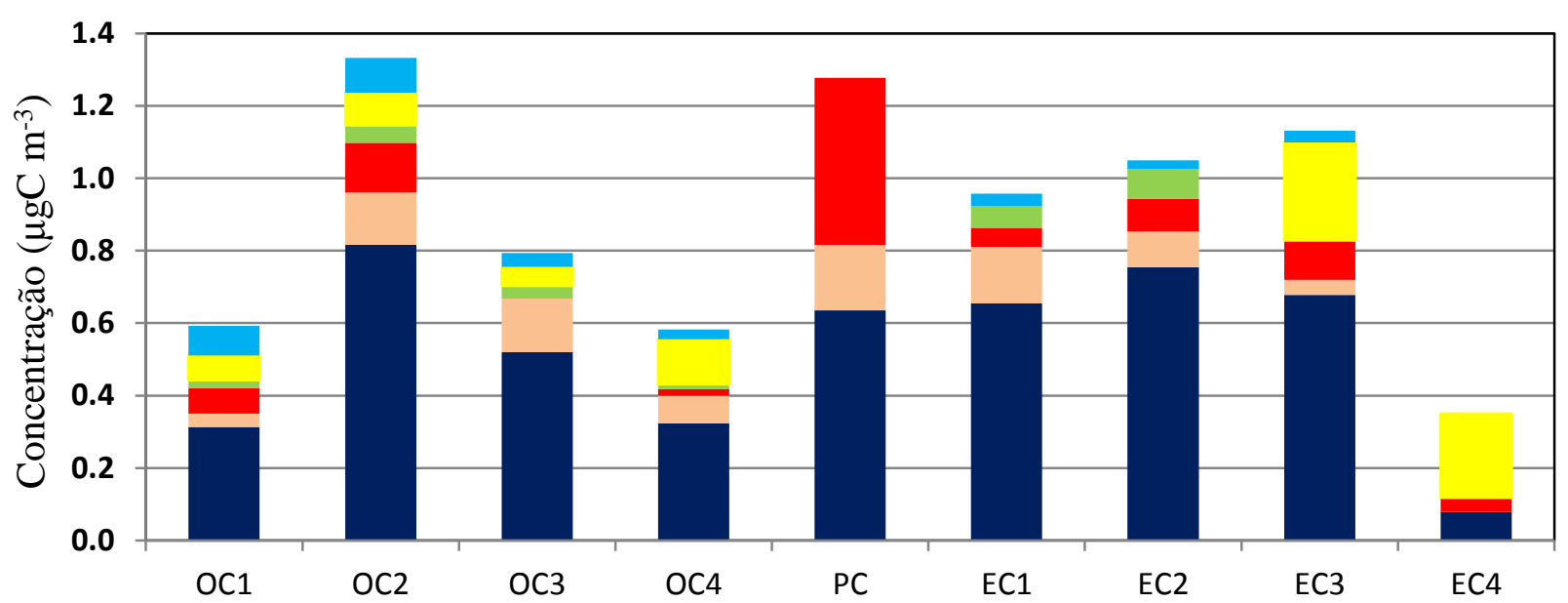

Figura 5-11 Atribuição de fontes do material particulado carbonáceo para o conjunto de dados das estações IFUSP, Cerqueira César e Ibirapuera.

Observa-se que a contribuição majoritária para as componentes carbonáceas deve-se ao setor veicular, responsável, em particular, por 70\% das concentrações de EC1 e EC2. A única exceção é a componente EC4, que tem apenas $20 \%$ apenas de sua massa atribuída às emissões veiculares. A componente de ressuspensão de solo, em geral, não contribui significativamente para nenhuma fração de carbono, como é esperado. A associação deste fator com $15 \%$ das concentrações OC4, PC e EC1, e quase $20 \%$ das concentrações de OC3, provavelmente se deve a covariabilidade entre ressuspensão de solo e emissões veiculares, como já discutido. O fator principal atribuído ao SOA, identificado pela associação majoritária com ácidos orgânicos, mostrou pouco impacto nas componentes carbonáceas discriminadas. No entanto, no caso da componente orgânica de mais alta volatilidade (OC1), esta componente foi a segunda fonte mais importante, com $15 \%$ da atribuição da massa. A regressão linear entre OC1 e alguns ácidos orgânicos resultou em ajustes com valores de $\mathrm{R}^{2}$ maiores que 0.7 , comprovando a forte correlação entre OC1 e essas espécies. Em particular a figura 5-12 mostra as séries temporais de $\mathrm{OC} 1$ e formiato. 


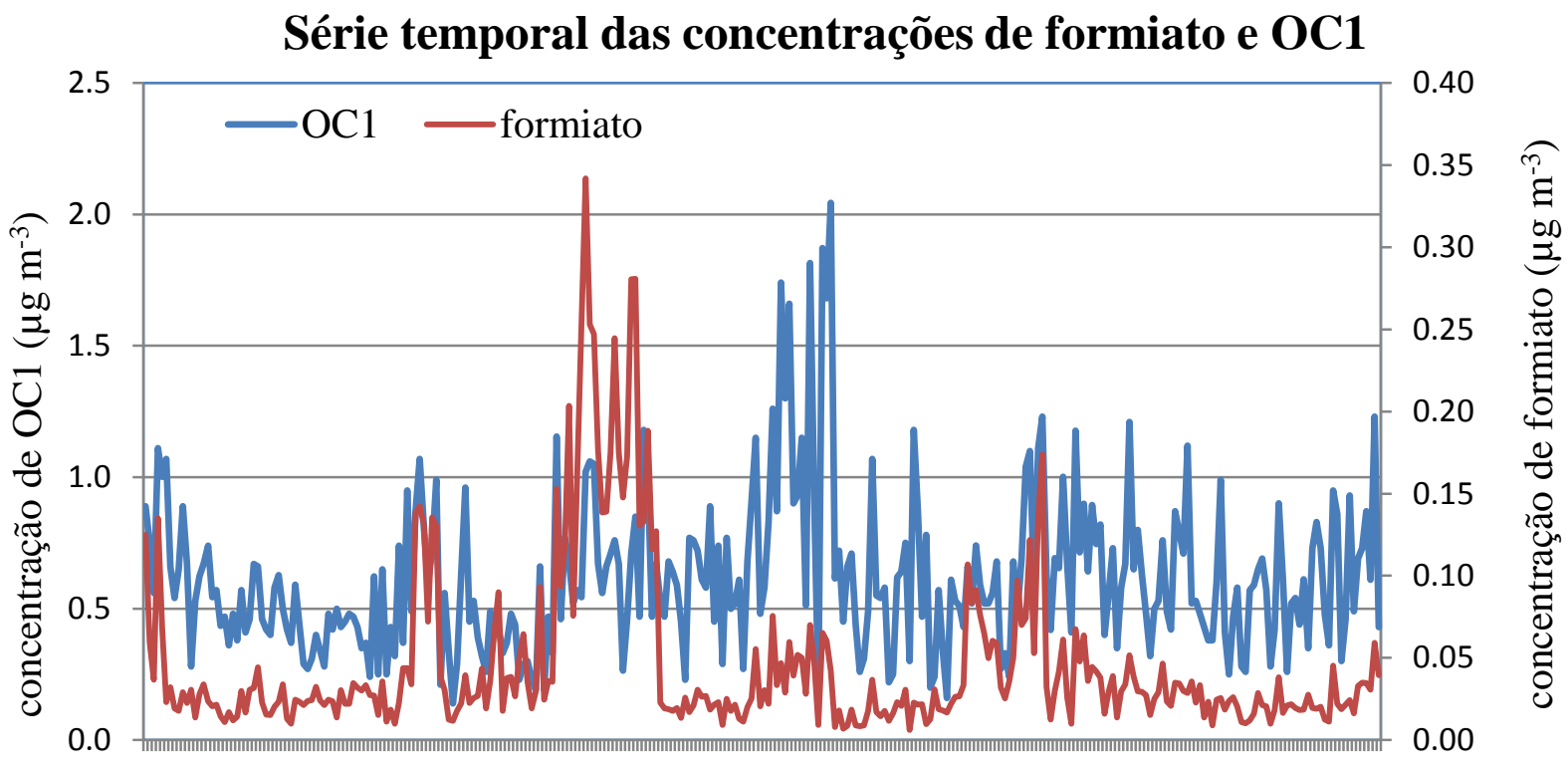

Figura 5-12 - Concentrações de formiato medido na fração fina e da fração mais volátil de carbono orgânico (OC1) para o conjunto de dados das estações amostradoras IBP, IFP e FSP no período de agosto de 2011 a janeiro de 2014.

Por fim, é notável a forte associação entre a componente de aerossóis de sulfato e a fração de carbono pirolítico. Embora, majoritariamente associada ao fator de emissões veiculares, mais de 35\% da massa de PC foi atribuída a esta componente. Em termos da massa total de carbono orgânico, este fator representa cerca de $15 \%$ do valor total medido. Zhao e Hopke (2006) sugerem que a ocorrência de S e PC em um mesmo fator principal possa estar associada à formação de aerossóis orgânicos secundários (SOA) via catálise ácida heterogênea entre o ácido $\mathrm{SO}_{4}{ }^{2-}$ e compostos orgânicos gasosos. Além disso a formação adicional de SOA pode ocorrer devido a condensação de compostos orgânicos semi-voláteis em partículas ácidas de sulfato (Jang et al., 2003; Kim e Hopke, 2006). Estes trabalhos propõem que componentes ricas em PC representem aerossóis orgânicos mais processados na atmosfera. Em outras palavras, partículas de $\mathrm{OC}$ mais oxidadas devido a reações com $\mathrm{OH}$ e O3. Segundo Yu et al. (2002), aerossóis orgânicos mais oxidados são menos voláteis e mais susceptíveis de pirolisar quando submetidas a altas temperaturas do que espécies de OC mais voláteis. Na figura 5-13 são mostradas séries temporais para sulfato e carbono pirolítico. 


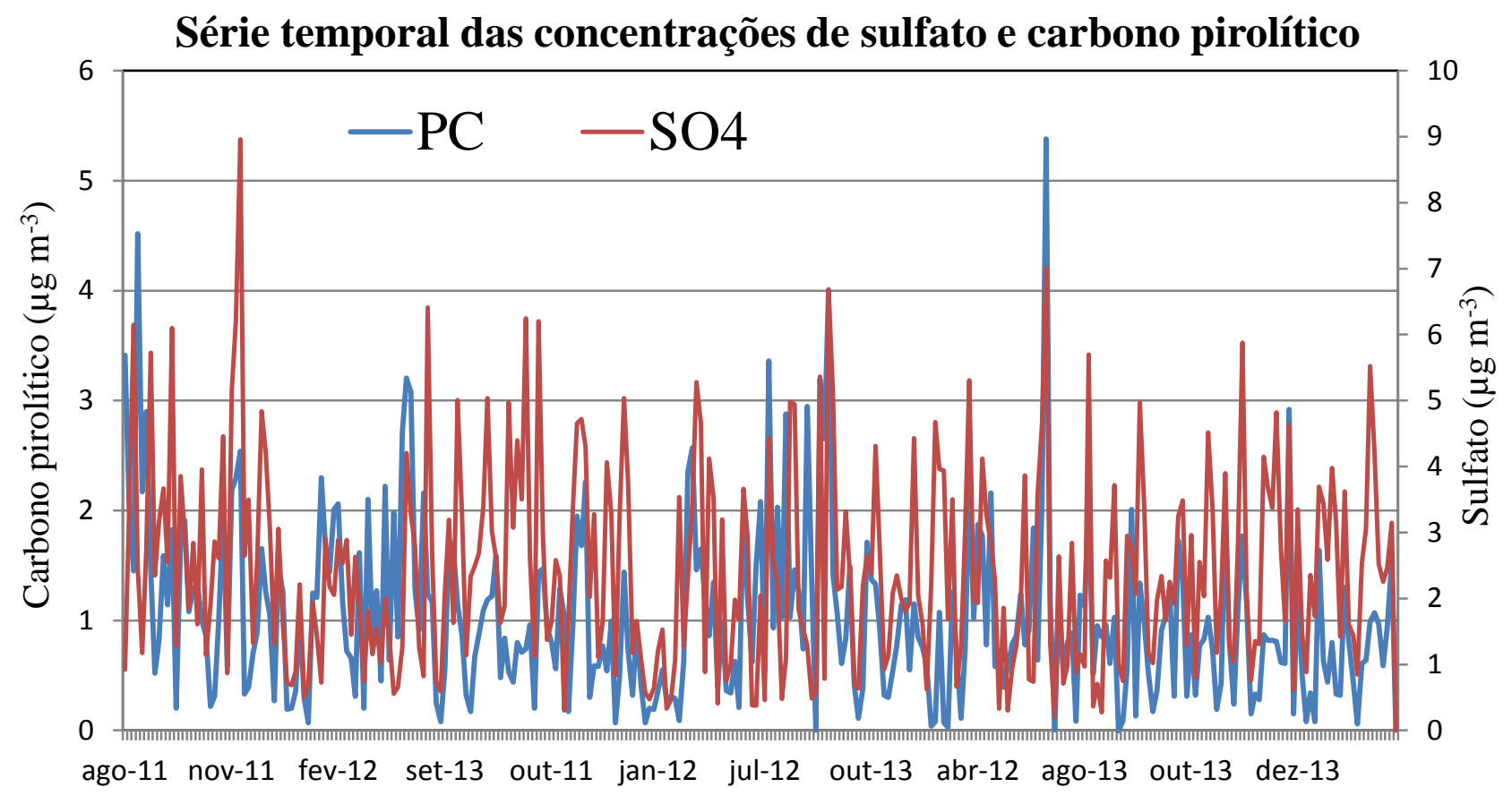

Figura 5-13 - Concentrações de sulfato medido na fração fina e da fração menos volátil de carbono orgânico (carbono pirolítico ou PC) para o conjunto de dados das estações amostradoras IBP, IFP e FSP no período de agosto de 2011 a janeiro de 2014. 


\section{Conclusões e considerações finais}

Neste trabalho apresentou-se um estudo detalhado acerca do material particulado presente na atmosfera da Região Metropolitana de São Paulo (RMSP), focado na caracterização e identificação de fontes deste material. Foram coletados, dentro do projeto FONTES, financiado pela Petrobrás ao longo de uma extensa campanha de amostragem, cerca de 400 filtros em quatro estações amostradoras com características distintas. Diferentes técnicas analíticas foram empregadas, permitindo a determinação quantitativa de um grande número de elementos e compostos químicos constituintes do material coletado nos filtros. A partir da comparação entre as diferentes técnicas analíticas e de amostragem verificou-se grande consistência nos resultados obtidos. A vasta base de dados contendo informações sobre a variabilidade temporal deste grande número de parâmetros foi utilizada para a determinação quantitativa de fontes através do uso de modelo receptor. Foram identificadas as principais componentes de emissão para aerossol atmosférico na RMSP, caracterizando-se as composições elementares e as variações temporais destas emissões, com destaque para o impacto do setor veicular.

Foi observada grande variabilidade das concentrações de material particulado nas quatro estações de amostragem. As concentrações do material particulado inalável $\left(\mathrm{PM}_{10}\right)$ variaram de 6 a $107 \mu \mathrm{g} \mathrm{m}^{-3}$ nas estações amostradoras do Ibirapuera (IBP), IFUSP (IFP), Congonhas (CGH) e Cerqueira César (FSP). Na fração fina $\left(\mathrm{PM}_{2.5}\right)$, foram verificadas concentrações na faixa entre 3 e $30 \mu \mathrm{g} \mathrm{m}^{-3}$, à exceção da estação CGH, onde não foi possível separar as frações fina e grossa dos aerossóis em decorrência de frequentes entupimentos nos filtros devido às altas concentrações verificadas neste sítio.

Para validação das medidas de material particulado inalável, obtidas pela técnica gravimétrica, foi realizada uma comparação detalhada com as concentrações de $\mathrm{PM}_{10}$ realizadas pela CETESB, nas estações de monitoramento fixas. Em CGH e IBP foram obtidos coeficientes de regressão linear estatisticamente significativos (1.07 e 1.02, respectivamente). No caso da FSP e do IFP, enquanto as estações de monitoramento da CETESB estavam ao nível do solo, as estações amostradoras deste projeto estavam no topo de edifícios, afetando a comparação. Além disso, no IFP a estação da CETESB não teve seu amostrador operando paralelamente durante toda a amostragem. A concordância dos resultados foi boa, apesar de as medidas da CETESB e 
do LFA serem baseadas em diferentes técnicas. Além disso, enquanto neste trabalho são amostrados filtros com médias de 24h, a CETESB utiliza medidas com resolução temporal de 30 minutos e determinações pelo princípio da absorção beta.

Foram determinadas as concentrações de black carbon equivalente (EBC) para os filtros nas frações fina e grossa. A concentração média de EBC medida nas estações IFP, FSP e IBP foi muito próxima, todas próximas de $2.5 \mu \mathrm{g} \mathrm{m}^{-3}$, predominando a contribuição da fração fina (87\% nos três casos). Na estação amostradora de CGH, por outro lado, foram observadas concentrações mais elevadas de EBC, com um valor médio de $12 \mu \mathrm{g} \mathrm{m}^{-3}$. Nas estações onde foi possível discriminar as concentrações nas modas fina e grossa, verificou-se que a contribuição do EBC para a massa de aerossóis é de 20 a 25\%, para a fração fina, mas inferior a 5\%, para o particulado grosso.

O material coletado nas estações IBP, IFP e FSP apresentou concentrações e composição química bastante semelhante indicando um aerossol bem misturado na atmosfera da RMSP. O conjunto de dados destas estações forneceu uma base de dados extensa com informações acerca dos aerossóis na atmosfera da RMSP. Foi verificado um perfil sazonal nas concentrações do $\mathrm{PM}_{2.5}$. Comparando-se os períodos de verão e inverno, observaram-se concentrações médias de 9.8 e $13.2 \mu \mathrm{g} \mathrm{m}^{-3}$, respectivamente. Em estudos anteriores na RMSP (Castanho, 1999) esse perfil de concentração foi verificado e atribuído à diferença entre as condições meteorológicas, mais favoráveis à dispersão de poluentes no período de verão.

Observou-se um perfil sazonal para as partículas de black carbon semelhante ao do $\mathrm{PM}_{2.5}$ ao analisar-se a série temporal da base de dados conjunta para estas estações. A concentração média de EBC observada na moda fina foi de 2.1 e $3.2 \mu \mathrm{g} \mathrm{m}^{-3}$ nos períodos de verão e inverno, respectivamente. A razão estre EBC e a massa total para o particulado na fração fina ao longo da série temporal se mantém em torno de $23 \%$.

Quanto à composição elementar inorgânica do material particulado, quantificada a partir da técnica de XRF (Fluorescência de Raios-X), foram encontradas contribuições principalmente dos elementos $\mathrm{S}, \mathrm{K}$, elementos de aerossóis marinhos ( $\mathrm{Na}, \mathrm{Cl}$ e $\mathrm{Mg}$ ) e elementos de ressuspensão de solo ( $\mathrm{Al}, \mathrm{Si}, \mathrm{Ca}$, Ti e Fe), com concentrações acima de $100 \mathrm{ng} \mathrm{m}^{-3}$ além das 
contribuições de elementos como $\mathrm{P}, \mathrm{Mn}, \mathrm{Cu}, \mathrm{Zn}$ e $\mathrm{Pb}$, estes em menor escala. Foram observadas composições elementares muito semelhantes para o $\mathrm{PM}_{10}$ em todas as estações, com exceção do elemento Fe que, na estação CGH, apresentou concentração média da ordem de $1.8 \mu \mathrm{g} \mathrm{m}^{-3}, 80 \%$ maior em relação aos demais sites de amostragem, e das concentrações de $\mathrm{Cu}$, relativamente maiores nas estações FSP e CGH em comparação a IFP e IBP. Observou-se uma composição elementar bastante distinta ao compararem-se os aerossóis nas modas fina e grossa. Enquanto na fração fina predominam as concentrações de $\mathrm{S}$ em relação aos demais elementos, na moda grossa verificou-se um impacto maior de aerossol marinho, potássio e principalmente aerossóis de ressuspensão de solo.

Determinou-se também, por cromatografia iônica (IC), elevado número de compostos iônicos presentes na fração do particulado solúvel em água. Esta análise foi aplicada apenas aos filtros das estações FSP, IBP e IFP. Na fração fina, verificou-se impacto predominante de aerossóis de sulfato de amônia $\left(\mathrm{SO}_{4}\right.$ e $\left.\mathrm{NH}_{4}\right)$. $\mathrm{Na}$ fração grossa, por outro lado, predominam sulfato e nitrato. A comparação entre os resultados obtidos por IC e pela técnica de XRF foi feita utilizando-se as medidas de $\mathrm{S}$ na forma elementar e $\mathrm{SO}_{4}$ na forma iônica. Os coeficientes obtidos na regressão linear $\mathrm{SO}_{4}$ versus $\mathrm{S}$ para as frações fina e grossa, para as três estações estiveram entre 2.91 e 3.12, mostrando que o $\mathrm{S}$ presente na atmosfera se encontra

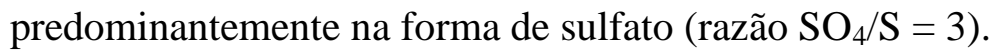

Paralelamente à amostragem dos filtros Nuclepore, a partir dos quais se quantificaram as concentrações de material particulado, black carbon equivalente e a composição elementar e iônica, foram coletados filtros de quartzo adequados à análise da componente orgânica dos aerossóis. Foram realizadas medidas de carbono orgânico e elementar, obtendo-se uma caracterização detalhada das diferentes componentes carbonáceas do material particulado atmosférico na RMSP. Foi utilizado um método termo-óptico de evolução de carbono no analisador da Sunset Instruments. O protocolo de temperatura utilizado na análise foi o EUSAAR_2, amplamente utilizado na determinação de OC e EC.

Novamente, foram obtidos resultados similares nas estações IBP, IFP e FSP. As concentrações médias nestas estações foram, respectivamente, $3.7,3.6$ e $3.5 \mu \mathrm{g} \mathrm{m}^{-3}$, para OC e 1.8, 2.2 e $2.4 \mu \mathrm{g} \mathrm{m}^{-3}$, para EC. Assim, verificaram-se valores da razão OC:EC iguais a 2.1, $1.8 \mathrm{e}$ 
1.6, respectivamente. Na estação amostradora CGH, a mais impactada por emissões veiculares, tanto a concentração média de OC $\left(6.4 \mu \mathrm{g} \mathrm{m}^{-3}\right)$ como de EC $\left(7.8 \mu \mathrm{g} \mathrm{m}^{-3}\right)$ foram muito maiores que nas demais estações, sobretudo no caso do EC. A razão OC:EC verificada em CGH foi de 0.8 .

Calculou-se, para as estações IBP, IFP e FSP, o balanço químico de massa. A composição química do material particulado foi discriminada nas diferentes componentes dos aerossóis. Na fração fina foi verificada contribuição majoritária da componente orgânica dos aerossóis, juntamente com sulfato e aerossóis absorvedoras de luz (black carbon ou carbono elementar). A massa orgânica (OM) estimada a partir da concentração média de OC, por um fator multiplicativo 1.4, representou 42, 45 e 58\% da média do $\mathrm{PM}_{2.5}$ medido nas estações IBP, FSP e IFP, respectivamente; partículas de sulfato contribuíram de 20 a 25\%; enquanto a participação de partículas de EC ou EBC variou, em geral, na faixa de 15 a 30\% da massa na fração fina. No caso da fração grossa do aerossol, verificou-se um material fortemente associado a emissões de poeira do solo, responsáveis por cerca de $40 \%$ das concentrações.

A identificação das fontes do material particulado foi obtida através do uso de modelo receptor. Foi utilizada a análise de fatores principais (PFA), técnica de análise estatística multivariada. A PFA foi aplicada às bases de dados com informações sobre o material particulado fino das estações IFP, FSP e IBP, onde foi possível discriminar as frações fina e grossa. As fontes ou processos de formação identificados foram basicamente os mesmos nos três casos. Isto mostrou que a estrutura de fontes tem composição bastante homogênea na RMSP.

A análise reduziu o espaço dimensional, com cerca de 30 variáveis, em cinco ou seis fatores principais, dependendo da estação amostradora. As principais fontes de emissão identificadas foram emissões veiculares, ressuspensão do solo, sulfato e emissões industriais. As componentes veicular e de solo, puderam apresentar covariabilidade e eventualmente foram identificadas num mesmo fator principal. Da mesma forma, emissões industriais e aerossóis de sulfato se apresentaram, em alguns casos, no mesmo fator. Foram feitas correções discriminando esses fatores a partir de seus traçadores e/ou considerações baseadas em inventários de emissões. A componente veicular foi identificada como a principal fonte de 
emissão para o material particulado fino com impacto majoritário superior a $60 \%$ em todas as estações amostradoras consideradas. A componente de sulfatos explicou de 15 a $21 \%$ da massa do $\mathrm{PM}_{2.5}$. Identificou-se o impacto de ressuspensão de poeira do solo, contribuindo de 7 a $12 \%$ da massa do particulado fino, e finalmente, as componentes de aerossol marinho e aerossol orgânico secundário representando em torno de 5\% cada.

A análise da base de dados conjunta das estações IFP, FSP e IBP mostrou resultados semelhantes, identificando cinco fatores, discriminados detalhadamente como: emissões veiculares $(62 \%)$, sulfato e emissões industriais (20\%), ressuspensão de poeira de solo (7\%), aerossol orgânico secundário (7\%) e aerossol marinho (2\%). Estudou-se a sazonalidade destes fatores, verificando que emissões veiculares, ressuspensão do solo e aerossóis orgânicos secundários apresentaram um impacto em torno de $70 \%$ maior nos meses de inverno; enquanto aerossóis de sulfato tiveram impacto mais acentuado no verão. Quanto à contribuição de aerossol marinho, esta componente mostrou grande variação ao longo da série temporal não sendo verificada nenhuma característica sazonal.

A aplicação do modelo receptor às diferentes frações de aerossóis carbonáceos $(\mathrm{OC} 1, \mathrm{OC} 2$, OC3, OC4, PC, EC1, EC2, EC3 e EC4) permitiu uma caracterização detalhada deste material a partir da identificação e quantificação das fontes desses aerossóis. Exceto pela fração de EC que evolui a mais altas temperaturas ( $\mathrm{EC} 4$, medida a $850^{\circ} \mathrm{C}$ ), todas as componentes carbonáceas foram associadas majoritariamente a emissões veiculares. Esse resultado indica que a maior parte deste material resulta de emissões primárias na forma de fuligem. Quanto à formação de aerossóis orgânicos secundários (SOA), identificou-se forte associação entre ácidos orgânicos (acetato, formiato e oxalato) e a fração OC1, indicando SOA de baixa volatilidade. Somado a isso, foi identificado um fator de aerossóis de sulfato fortemente associada ao carbono pirolítico (PC). Diversos trabalhos baseados em modelos receptores identificaram este fator (Kim e Hopke, 2006; Zhao e Hopke, 2006) associando a formação de carbono orgânico secundário. Aerossóis envelhecidos são mais oxidados na atmosfera e, portanto, menos voláteis. Essa característica faz com que estes tendam a sofrer a pirólise durante a análise térmica, formando PC. Dentro desta hipótese, esse mecanismo foi responsável por $15 \%$ da concentração de carbono orgânico total. Contudo, mais estudos são necessários para entender a natureza dessas partículas. 
Comparando os resultados obtidos neste trabalho com outros estudos semelhantes realizados na Região Metropolitana de São Paulo (Castanho, 1999; Andrade, 1993b), foram obtidos valores absolutamente consistentes em termos da composição média do material particulado. No caso do particulado fino, foram reportadas frações entre 20 e $30 \%$ para black carbon, e na faixa de 35 a 45\% para carbono orgânico. Quanto à componente inorgânica, estes trabalhos encontraram concentrações majoritárias de sulfatos correspondendo a cerca de $20 \%$ da massa. No caso da fração grossa, os resultados deste trabalho convergiram com resultados anteriores mostrando impacto predominante de ressuspensão de solo.

Nos resultados da aplicação dos modelos receptores, foram identificados fatores semelhantes na análise do material particulado na fração fina. À exceção da componente de aerossóis orgânicos secundários (SOA) que não havia sido identificada anteriormente, mas que pôde ser identificada neste trabalho graças à inclusão de ácidos orgânicos (medidos por cromatografia iônica) no modelo. Por outro lado, no que diz respeito à quantificação de fontes, as análises desenvolvidas neste trabalho forneceram resultados diferentes. As estimativas obtidas neste trabalho são mais precisas, tendo em vista o maior número de parâmetros utilizados e o fato de que na atribuição de fontes foi considerada a covariabilidade entre as componentes de suspensão de solo e de sulfatos com a componente veicular. Assim, a estimativa da contribuição do setor veicular para o $\mathrm{PM}_{2.5}$ foi maior $(60 \%)$ em relação aos estudos anteriores (entre 30 e 40\%) nos quais a atribuição de fontes não foi corrigida como neste trabalho. Além disso, os resultados da aplicação de modelos receptores foram consistentes com o último inventário de emissões da CETESB (CETESB, 2012), onde se estimou que emissões veiculares podem ser responsáveis por até $65 \%$ das concentrações de material particulado observadas na RMSP, conforme apresentado na seção 1.5 deste trabalho.

Dentro do contexto da poluição do ar em ambientes urbanos, este trabalho traz contribuições do ponto de vista da compreensão dos mecanismos de emissão e formação de poluentes em uma atmosfera extremamente complexa e dinâmica como a da Região Metropolitana de São Paulo. Todas as análises mostraram resultados que identificaram a significativa influência do setor veicular nas concentrações de material particulado fino devido a emissões diretas do tráfego, mas também por uma fração significativa da ressuspensão de poeira do solo, atribuída à circulação de veículos. 


\section{Referências Bibliográficas}

Andrade, M. F. (1993a) Identificação de Fontes da Matéria Particulada do Aerossol Atmosférico De São Paulo. Tese (Doutorado em Física Nuclear) - Instituto de Física, Universidade de São Paulo, São Paulo, 1993. Disponível em: $<$ http://www.teses.usp.br/teses/disponiveis/43/43131/tde-01072013-164055/>. Acesso em: 2015-04-12.

Andrade, F., C. Orsini, and W. Maenhaut (1993b) Receptor modeling for inhalable atmospheric particles in Sao Paulo, Brazil: Nuclear Instruments and Methods in Physics Research Section B: Beam Interactions with Materials and Atoms, v. 75, p. 308-311.

Andrade, F., C. Orsini, and W. Maenhaut (1994) Relation between aerosol sources and meteorological parameters for inhalable atmospheric particles in Sao Paulo City, Brazil: Atmospheric Environment, v. 28, p. 2307-2315.

Andrade, M. d. F., R. de Miranda, A. Fornaro, A. Kerr, B. Oyama, P. de Andre, and P. Saldiva (2012) Vehicle emissions and PM2.5 mass concentrations in six Brazilian cities: Air Quality, Atmosphere \& Health, v. 5, p. 79-88.

Andreae, M. O., and A. Gelencsér (2006) Black carbon or brown carbon? The nature of lightabsorbing carbonaceous aerosols: Atmos. Chem. Phys., v. 6, p. 3131-3148.

Arana, A. A. (2014) Aerossóis Atmosféricos na Amazônia: Composição elementar orgânica e inorgânica em regiões com diferentes usos do solo. Tese (Doutorado em Clima e Ambiente) - Instituto Nacional de Pesquisas da Amazônia, Universidade do Estado do Amazonas, Manaus, 2014.

Artaxo Netto, P. E. (1985) Modelos receptores aplicados a determinação da estrutura de fontes de aerossóis remotos. Tese (Doutorado em Física Nuclear) - Instituto de Física, Universidade de São Paulo, São Paulo, 1985. Disponível em: $<$ http://www.teses.usp.br/teses/disponiveis/43/43131/tde-02072012-150232/>. Acesso em: 2015-04-12.

Artaxo, P., F. Gerab, M. A. Yamasoe, and J. V. Martins (1994) Fine mode aerosol composition at three long-term atmospheric monitoring sites in the Amazon Basin: Journal of Geophysical Research: Atmospheres, v. 99, p. 22857-22868.

Artaxo, P., W.E. Castro, M. freitas, K.M. Longo. (1995) Receptor Modeling of Atmospheric aerosols in the urban area of São Paulo. In: Applied Research on air pollution using nuclear-related analytical techniques, IAEA (International Atomic Energy Agency). Publication NAHRES, vol. 26, p. 5-11.

Artaxo, P., A.D.A. Castanho. (1998) Aerosol Concentrations and Source apportionment in the urban area of São Paulo, Brazil. IAEA (International Atomic Energy Agency) TEC DOC series. 02/ 1998.

Austin, J., P. Brimblecombe, and W. T. Sturges (2002) Air Pollution Science for the 21st Century: Developments in Environmental Science, Elsevier Science.

Backman, J., L. V. Rizzo, J. Hakala, T. Nieminen, H. E. Manninen, F. Morais, P. P. Aalto, E. Siivola, S. Carbone, R. Hillamo, P. Artaxo, A. Virkkula, T. Petäjä, and M. Kulmala 
(2012) On the diurnal cycle of urban aerosols, black carbon and the occurrence of new particle formation events in springtime São Paulo, Brazil: Atmos. Chem. Phys., v. 12, p. 11733-11751.

Baird, C.; Cann, M. (2011) Química ambiental. 4. ed. Porto Alegre: Bookman, 2011. 844p.

Birch, M. E., and R. A. Cary (1996) Elemental Carbon-Based Method for Monitoring Occupational Exposures to Particulate Diesel Exhaust: Aerosol Science and Technology, v. 25, p. 221-241.

Bond, T. C., et al. (2013) Bounding the role of black carbon in the climate system: A scientific assessment: Journal of Geophysical Research: Atmospheres, v. 118, p. 5380-5552.

Braga, A.L.F., P.H.N. Saldiva, L.A.A. Pereira,J.J.C. Menezes, G.M.S. Conceição, C.A. Lin, A. Zanobetti, J. Schwartz, D.W. Dockery, (2001), Health effects of air pollution exposure on children and adolescents in São Paulo, Brazil Pediatr. Pulmonol., 31 (2), pp. 106-113 http://dx.doi.org/10.1002/1099-0496(200102)31:2<106::AID-PPUL1017>3.0.CO;2-M

Brito, J., L. V. Rizzo, P. Herckes, P. C. Vasconcellos, S. E. S. Caumo, A. Fornaro, R. Y. Ynoue, P. Artaxo, and M. F. Andrade (2013) Physical-chemical characterisation of the particulate matter inside two road tunnels in the São Paulo Metropolitan Area: Atmos. Chem. Phys., v. 13, p. 12199-12213.

Castanho, A. D. A. (1999) A Determinação Quantitativa de Fontes de Material Particulado na Atmosfera da Cidade de São Paulo. Dissertação (Mestrado em Física Nuclear) Instituto de Física, Universidade de São Paulo, São Paulo, 1999. Disponível em: $<$ http://www.teses.usp.br/teses/disponiveis/43/43131/tde-19122003-145359/>. Acesso em: 2015-04-12.

Carvalho, V. S. B., E. D. Freitas, L. D. Martins, J. A. Martins, C. R. Mazzoli, M. F. Andrade, (2015), Air quality status and trends over the Metropolitan Area of São Paulo, Brazil as a result of emission control policies, Environmental Science \& Policy, Volume 47, March 2015, Pages 68-79, ISSN 1462-9011, http://dx.doi.org/10.1016/j.envsci.2014.11.001.

Cavalli, F., M. Viana, K. E. Yttri, J. Genberg, and J. P. Putaud (2010) Toward a standardised thermal-optical protocol for measuring atmospheric organic and elemental carbon: the EUSAAR protocol: Atmos. Meas. Tech., v. 3, p. 79-89.

CETESB (2009) Material particulado inalável fino (MP2,5) e grosso (MP2,5 - 10) na atmosfera da região metropolitana de são paulo (2000 - 2006): Publicação CETESB, São Paulo.

CETESB (2012) Relatório de Qualidade do Ar no Estado de São Paulo. Publicação CETESB. Série de Relatórios/ CETESB, São Paulo.

CETESB (2013) Qualidade do ar no estado de São Paulo 2013. Publicação CETESB. Série Relatórios /CETESB, ISSN 0103-4103, São Paulo.

Chow, J. C., J. G. Watson, L. C. Pritchett, W. R. Pierson, C. A. Frazier, and R. G. Purcell (1993) The dri thermal/optical reflectance carbon analysis system: description, evaluation and applications in U.S. Air quality studies: Atmospheric Environment. Part A. General Topics, v. 27, p. 1185-1201.

Chow, J. C., J. G. Watson, L. W. A. Chen, W. P. Arnott, H. Moosmüller, and K. Fung (2004) Equivalence of Elemental Carbon by Thermal/Optical Reflectance and Transmittance 
with Different Temperature Protocols: Environmental Science \& Technology, v. 38, p. 4414-4422.

Conny, J. M., D. B. Klinedinst, S. A. Wight, and J. L. Paulsen (2003) Optimizing ThermalOptical Methods for Measuring Atmospheric Elemental (Black) Carbon: A Response Surface Study: Aerosol Science and Technology, v. 37, p. 703-723.

Després, V. R., J. A. Huffman, S. M. Burrows, C. Hoose, A. S. Safatov, G. Buryak, J. FröhlichNowoisky, W. Elbert, M. O. Andreae, U. Pöschl, and R. Jaenicke (2012) Primary biological aerosol particles in the atmosphere: a review: Tellus B; Vol 64 (2012).

Emplasa (2011) Por Dentro da Região Metropolitana de São Paulo - RMSP: Publicação Emplasa (Empresa Paulista de Planejamento Metropolitano SA), São Paulo.

Fenger, J. (1999) Urban air quality: Atmospheric Environment, v. 33, p. 4877-4900.

Gerab, F.. (1996) Técnicas analíticas nucleares aplicadas a medida em larga escala de aerossóis atmosféricos na região amazônica. 1996. Tese (Doutorado em Física Nuclear) - Instituto de Física, Universidade de São Paulo, São Paulo, 1996. Disponível em: $\quad<$ http://www.teses.usp.br/teses/disponiveis/43/43131/tde-04102012-144415/>. Acesso em: 2015-04-12.

Gilardoni, S., Vignati, E., Marmer, E., Cavalli, F., Belis, C., Gianelle, V., Loureiro, A., and Artaxo, P. (2011) Sources of carbonaceous aerosol in the Amazon basin, Atmos. Chem. Phys., 11, 2747-2764, doi:10.5194/acp-11-2747-2011.

Gurjar, B. R., T. M. Butler, M. G. Lawrence, and J. Lelieveld (2008) Evaluation of emissions and air quality in megacities: Atmospheric Environment, v. 42, p. 1593-1606.

Henry, R. C. (2002). Multivariate receptor models-current practice and future trends. Chemometrics and Intelligent Laboratory Systems, 60(1-2), 43-48. doi:10.1016/S01697439(01)00184-8

Hopke, P. K., E. S. Gladney, G. E. Gordon, W. H. Zoller, and A. G. Jones (1976) The use of multivariate analysis to identify sources of selected elements in the Boston urban aerosol: Atmospheric Environment (1967), v. 10, p. 1015-1025.

Hopke, P. K. (1991) An introduction to receptor modeling: Chemometrics and Intelligent Laboratory Systems, v. 10, p. 21-43.

Hopke, P. K. (2003) Recent developments in receptor modeling: Journal of Chemometrics, v. 17, p. 255-265.

IBGE (2010) Censo Demográfico 2010, Instituto Brasileiro de Geografia e Estatística.

IBOPE (2009), Indicadores de Percepção da Cidade de São Paulo: IBOPE e Movimento Nossa São Paulo, São Paulo.

Jang, M., S. Lee, and R. M. Kamens (2003) Organic aerosol growth by acid-catalyzed heterogeneous reactions of octanal in a flow reactor: Atmospheric Environment, v. 37, p. 2125-2138.

Kanakidou, M., Seinfeld, J. H., Pandis, S. N., Barnes, I., Dentener, F. J., Facchini, M. C., Van Dingenen, R., Ervens, B., Nenes, A., Nielsen, C. J., Swietlicki, E., Putaud, J. P., Balkanski, Y., Fuzzi, S., Horth, J., Moortgat, G. K., Winterhalter, R., Myhre, C. E. L., 
Tsigaridis, K., Vignati, E., Stephanou, E. G., and Wilson, J ,, (2005), Organic aerosol and global climate modelling: a review: Atmos. Chem. Phys., v. 5, p. 1053-1123.

Kim, E., and P. K. Hopke (2006) Characterization of fine particle sources in the Great Smoky Mountains area: Science of The Total Environment, v. 368, p. 781-794.

Kleeman, M. J., J. J. Schauer, and G. R. Cass (2000) Size and Composition Distribution of Fine Particulate Matter Emitted from Motor Vehicles: Environmental Science \& Technology, v. 34, p. 1132-1142.

Kowarick, L., e T. Rezende (2000), Escritos urbanos, Editora 34, São Paulo.

Lenzi, E., Favero, L. O. B. (2011) Introdução à Química da Atmosfera - Ciência Vida e Sobrevivência: LTC Rio de Janeiro (RJ)

Lopes, F. J. S., G. L. Mariano, E. Landulfo, and E. V. C. Mariano (2012) Impacts of Biomass Burning in the Atmosphere of the Southeastern Region of Brazil Using Remote Sensing Systems, Atmospheric Aerosols - Regional Characteristics - Chemistry and Physics, Dr. Hayder Abdul-Razzak (Ed.).

Loureiro, A.L., Ribeiro, A.C., Artaxo, P., Yamasoe, M.A. (1994). Calibration of refletometer system to measure black carbon and field intercomparation in the Amazon Basin. 5th International Conference on Carbonaceous Particles in the Atmosphere, Berkley, California, USA.

Maenhaut, W., Raes, N., Chi, X. G., Cafmeyer, J., Wang, W., \& Salma, I. (2005). Chemical composition and mass closure for fine and coarse aerosols at a kerbside in Budapest, Hungary, in spring 2002. X-Ray Spectrometry, 34, 290-296.

Martins, J. V. (1999) O efeito de partículas de aerossol de queimadas da Amazônia no balanço radiativo da atmosfera., São Paulo, Universidade de São Paulo - USP.

Martins, L.C., R. Latorre Mdo, P.H. Saldiva, A.L. Braga (2002) Air pollution and emergency room visits due to chronic lower respiratory diseases in the elderly: an ecological timeseries study in Sao Paulo, Brazil J. Occup. Environ. Med., 44 (7) (2002), pp. 622-627

Miranda, R. M., M. F. Andrade, A. Worobiec, and R. V. Grieken (2002) Characterisation of aerosol particles in the São Paulo Metropolitan Area: Atmospheric Environment, v. 36, p. 345-352.

Monks, P. S., et al. (2009) Atmospheric composition change - global and regional air quality: Atmospheric Environment, v. 43, p. 5268-5350.

Nogueira, T., P. A. Dominutti, L. R.F. de Carvalho, A. Fornaro, M. F. Andrade (2014) Formaldehyde and acetaldehyde measurements in urban atmosphere impacted by the use of ethanol biofuel: Metropolitan Area of Sao Paulo (MASP), 2012-2013, Fuel, Volume 134, 15 October 2014, Pages 505-513, ISSN 0016-2361, http://dx.doi.org/10.1016/j.fuel.2014.05.091.

Oberdörster, G., E. Oberdörster, and J. Oberdörster,"Nanotoxicology: an emerging discipline evolving from studies of ultrafine particles." Environmental health perspectives (2005): 823-839. 
ONU (2014) World Urbanization Prospects: The 2014 Revision, Highlights (ST/ESA/SER.A/352). UN, Department of Economic and Social Affairs, Population Division.

Orsini, C. Q., M. H. Tabacniks, P. Artaxo, M. F. Andrade, and A. S. Kerr (1986) Characteristics of fine and coarse particles of natural and urban aerosols of Brazil: Atmospheric Environment (1967), v. 20, p. 2259-2269.

Parish, D. D., e T. Zhu, Clean Air for megacities, Science, Vol 326, pp 674-675, DOI: 10.1126/science.1176064, 2009.

Peterson, M. R., and M. H. Richards (2002) Thermal-opticaltransmittanceanalysis for organic, elemental, carbonate, totalcarbon, and OCX2 in PM2.5 by the EPA/NIOSH method, in: Proceedings, Symposium on Air Quality Measurement Methods and Technology-2002, edited by: Winegar, E. D. and Tropp, R. J., Air \& Waste Management Association, Pittsburgh, PA, 83-1-83-19.

Petzold, A., Ogren, J. A., Fiebig, M., Laj, P., Li, S.-M., Baltensperger, U., Holzer-Popp, T., Kinne, S., Pappalardo, G., Sugimoto, N., Wehrli, C., Wiedensohler, A., and Zhang, X.-Y. (2013) Recommendations for reporting "black carbon" measurements, Atmos. Chem. Phys., 13, 8365-8379, doi:10.5194/acp-13-8365-2013.

Pope, C. A., and D. W. Dockery (2006) Health effects of fine particulate air pollution: lines that connect: Journal of the Air \& Waste Management Association, v. 56, p. 709-742.

Reisinger, P., A. Wonaschütz, R. Hitzenberger, A. Petzold, H. Bauer, N. Jankowski, H. Puxbaum, X. Chi, and W. Maenhaut (2008) Intercomparison of Measurement Techniques for Black or Elemental Carbon Under Urban Background Conditions in Wintertime: Influence of Biomass Combustion: Environmental Science \& Technology, v. 42, p. 884889.

RIBEIRO, A. A. (2011) Estudo de correlação das internações hospitalares por câncer, poluição relacionada ao tráfego e nível sócio-econômico no município de São Paulo. Dissertação (Mestrado em Saúde Ambiental) - Faculdade de Saúde Pública, Universidade de São Paulo, São Paulo. Disponível em: <http://www.teses.usp.br/teses/disponiveis/6/6134/tde-13092011115456/>. Acesso em: 2015-04-12.

Saldiva, P.H.N., King, M., Delmonte, V.L.C., Macchione, M., Parada, M.A.C., Daliberto, M.L., Sakae, R.S., Criado, P.M.P., Silveira, P.L.P., Zin, W.A., Bom, G.M. (1992). Respiratory Alterations due to urban air pollution: an experimental study in rats. Environmental Research, Vol.57, p.19-33.

Saldiva, P.H.N., Lichtenfels, A.J.F.C., Paiva, P.S.O., Barone, I.A., Martins, M.A., Massad, E., Pereira, J.C.R., Xavier, V.P., Singer, J.M., Bohm, G.M. (1994). Association between air pollution and mortality due to respiratory dieseases in children in São Paulo, Brazil: a preliminar report. Environmental Research. Vol.65, p.218-225.

Saldiva, P.H.N., Pope, C.A., Schwartz, J., Dockery, D.W., Lichtenfels, A.J., Salge, J.M., Barone, I., Bohm, G.M. (1995). Air pollution and mortality in elderly people: a timeseries study in Sao Paulo, Brazil. Archives Environmental Health 50, 159-163. 
Saldiva, P., and E. Vormittag (2013) Avaliação do impacto da poluição atmosférica no Estado de São Paulo sob a visão da saúde, São Paulo: Instituto Saúde e Sustentabilidade.

Santana, E., K. B. d. Cunha, A. L. Ferreira, and A. Zamboni (2012) Padrões de qualidade do ar : experiência comparada Brasil, EUA e União Européia, São Paulo : Instituto de Energia e Meio Ambiente.

Satheesh, S. K., and K. Krishna Moorthy (2005) Radiative effects of natural aerosols: A review: Atmospheric Environment, v. 39, p. 2089-2110.

Seinfeld, J. H., and S. N. Pandis (1998) Atmospheric Chemistry and Physics - From Air Pollution to Climate Change: New York, U.S.A., Wiley.

Silva, F. R., U. P. Santos, P. H. N. Saldiva, L. F. A. Lourenço, and S. G. K. Miraglia (2012) Health Risks and Economic Costs of Absenteeism Due to Air Pollution in São Paulo, Brazil, Aerosol and Air Quality Research 10/2012; 12(5):826-833.

Swietlicki, E., Puri, S., Hansson, H.-C., \& Edner, H. (1996). Urban air pollution source apportionment using a combination of aerosol and gas monitoring techniques. Atmospheric Environment, 30(15), 2795-2809. doi:10.1016/1352-2310(95)00322-3

Turpin, B. J., P. Saxena, and E. Andrews (2000) Measuring and simulating particulate organics in the atmosphere: problems and prospects: Atmospheric Environment, v. 34, p. 29833013.

Ulbrich, I. M., M. R. Canagaratna, M. J. Cubison, Q. Zhang, N. L. Ng, a. C. Aiken, and J. L. Jimenez (2012) "Three-dimensional Factorization of Size-resolved Organic Aerosol Mass Spectra from Mexico City." Atmospheric Measurement Techniques 5 (1) (January 25): 195-224. doi:10.5194/amt-5-195-2012. http://www.atmos-meas-tech.net/5/195/2012/.

Veronez, D., L. Kulay, P. Saldiva and S. Miraglia (2012) A Cost-Benefit Evaluation of the Air Quality and Health Impacts in São Paulo, Brazil: Journal of Environmental Protection, Vol. 3 No. 9A pp. 1161-1166. doi: 10.4236/jep.2012.329134.

Weaver, E. C., and L. S. Foster (1954) "Chemistry for our times", McGraw-Hill Book Company, New York.

WHO (2014) Public Health, Environm ental and Social Determinants of Health (PHE). Geneva, World Health Organization.

Yu, J. Z., J. Xu, and, and H. Yang (2002) Charring Characteristics of Atmospheric Organic Particulate Matter in Thermal Analysis: Environmental Science \& Technology 200236 (4), 754-761 DOI: $10.1021 / \mathrm{es} 015540 \mathrm{q}$

Zhao, W., and P. K. Hopke (2006) Source identification for fine aerosols in Mammoth Cave National Park: Atmospheric Research, v. 80, p. 309-322.

Zhu T et al. (2012) WMO/IGAC Impacts of Megacities on Air Pollution and Climate. GAW Report 205. (Lead authors: Tong Zhu, Megan L. Melamed, David Parrish, Michael Gauss, Laura Gallardo Klenner, Mark Lawrence, Abdourahamane Konare and Cathy Liousse), ISBN: 978-0-9882867-0-2, 309 pp. 


\section{APENDICE A - Tabelas ocultadas na seção 5: Quantificação de fontes na RMSP}

\begin{tabular}{|c|c|c|c|c|c|c|c|}
\hline \multirow{3}{*}{ Espécie } & \multicolumn{6}{|c|}{ Fator Principal } & \multirow{3}{*}{ Percentual Explicado } \\
\hline & 1 & 2 & 3 & 4 & 5 & 6 & \\
\hline & \multicolumn{6}{|c|}{ Concentracão $\left(\mu \mathrm{g} \mathrm{m}^{-3}\right)$} & \\
\hline PM2.5 & 0.40 & 3.09 & 7.21 & 0.05 & 0.49 & 0.45 & $98 \%$ \\
\hline $\mathrm{Al}$ & 35.30 & 16.43 & 62.65 & - & 24.45 & 5.06 & $97 \%$ \\
\hline $\mathrm{Si}$ & 38.27 & 27.77 & 66.42 & 28.16 & 33.62 & - & $96 \%$ \\
\hline $\mathrm{Ca}$ & 7.40 & 10.84 & 12.84 & 14.19 & 10.67 & 2.55 & $98 \%$ \\
\hline $\mathrm{Ti}$ & 3.73 & 1.52 & 7.34 & 2.02 & 1.54 & 1.04 & $99 \%$ \\
\hline $\mathrm{Fe}$ & 23.14 & 41.91 & 53.78 & 61.21 & 20.50 & 12.89 & $99 \%$ \\
\hline $\mathrm{OC}$ & 0.23 & 0.08 & 3.14 & -0.05 & 0.28 & 0.07 & $101 \%$ \\
\hline $\mathrm{EC}$ & 0.05 & -0.24 & 1.69 & 0.17 & 0.06 & 0.07 & $98 \%$ \\
\hline $\mathrm{EBC}$ & 0.03 & - & 1.98 & 0.27 & -0.10 & 0.09 & $95 \%$ \\
\hline $\mathrm{CO}$ & - & 0.09 & 0.38 & 0.09 & - & - & $86 \%$ \\
\hline NOx & 0.81 & - & 16.49 & 3.48 & - & - & $86 \%$ \\
\hline $\mathrm{Na}$ & 1.87 & 38.59 & - & 24.42 & 45.11 & - & $104 \%$ \\
\hline $\mathrm{Mg}$ & 2.31 & - & 4.43 & - & 6.00 & - & $61 \%$ \\
\hline $\mathrm{P}$ & 0.48 & 19.76 & - & 5.45 & 2.56 & -1.33 & $96 \%$ \\
\hline $\mathrm{S}$ & 10.57 & 625.55 & -51.85 & 192.61 & 83.29 & -18.73 & $99 \%$ \\
\hline $\mathrm{Cl}$ & 0.19 & 1.99 & - & 1.54 & 3.19 & - & $97 \%$ \\
\hline $\mathrm{K}$ & 20.92 & 13.32 & 59.72 & 15.55 & 27.83 & 21.90 & $101 \%$ \\
\hline $\mathrm{V}$ & 0.05 & 1.11 & - & 0.33 & 0.28 & -0.11 & $108 \%$ \\
\hline $\mathrm{Cr}$ & 0.14 & - & 0.58 & 0.40 & - & 0.08 & $94 \%$ \\
\hline $\mathrm{Mn}$ & 0.25 & 1.83 & - & 2.51 & 0.45 & 0.24 & $96 \%$ \\
\hline $\mathrm{Ni}$ & 0.02 & 0.43 & - & 0.59 & 0.07 & - & $97 \%$ \\
\hline $\mathrm{Cu}$ & 0.35 & 0.88 & 2.25 & 3.04 & 0.45 & 0.32 & $98 \%$ \\
\hline $\mathrm{Zn}$ & - & 11.96 & 2.83 & 24.67 & 3.61 & - & $98 \%$ \\
\hline As & - & - & 0.31 & 0.37 & 0.27 & -0.20 & $73 \%$ \\
\hline $\mathrm{Se}$ & 0.16 & 0.75 & 0.69 & 1.08 & - & - & $91 \%$ \\
\hline $\mathrm{Br}$ & 0.14 & 0.86 & - & 0.86 & 0.87 & 0.25 & $103 \%$ \\
\hline $\mathrm{Pb}$ & 0.17 & 2.11 & - & 5.91 & 0.90 & 0.81 & $94 \%$ \\
\hline $\mathrm{Na}^{+}(\mathrm{IC})$ & 9.84 & 26.13 & 26.04 & 23.67 & 73.23 & 6.62 & $97 \%$ \\
\hline $\mathrm{K}^{+}(\mathrm{IC})$ & 14.36 & - & 80.51 & - & 22.53 & 38.25 & $105 \%$ \\
\hline $\mathrm{Mg} 2+(\mathrm{IC})$ & 1.72 & - & 6.64 & - & 7.01 & - & $79 \%$ \\
\hline $\mathrm{Ca} 2+(\mathrm{IC})$ & 5.09 & 7.76 & 20.25 & 8.78 & 8.90 & 9.09 & $98 \%$ \\
\hline NH4+ (IC) & -9.41 & 738.53 & -69.27 & 131.94 & -54.42 & 105.96 & $99 \%$ \\
\hline Acetato (IC) & 0.86 & 8.17 & 12.85 & 11.33 & - & 27.75 & $99 \%$ \\
\hline Formiato (IC) & 2.93 & -5.86 & 24.48 & - & 4.00 & 9.94 & $97 \%$ \\
\hline Cl- (IC) & 3.94 & -15.33 & 30.06 & - & 20.82 & 7.98 & $100 \%$ \\
\hline NO3-(IC) & 4.84 & -23.04 & 68.61 & - & 25.20 & 21.03 & $101 \%$ \\
\hline SO42-(IC) & - & 2053.15 & - & 371.46 & 153.89 & 182.27 & $102 \%$ \\
\hline Oxalato (IC) & 5.09 & 34.84 & 44.00 & 9.14 & 6.69 & 22.17 & $97 \%$ \\
\hline
\end{tabular}

Tabela A-1 - Concentrações absolutas discriminadas em cada uma das seis fontes de material particulado retidas na análise de fatores principais na fração fina para a estação IBP. As concentrações são dadas em ng $\mathrm{m}^{-3}$, à exceção das variáveis OC, EC, EBC e $\mathrm{PM}_{2.5}$, expressas em $\mu \mathrm{g} \mathrm{m} \mathrm{m}^{-3}$, e dos gases $\mathrm{CO}$ e $\mathrm{NO}_{\mathrm{x}}$, em ppm. As concentrações destacadas em negrito indicam as contribuições majoritárias. O percentual explicado indica a razão entre a soma das atribuições e o valor medido. As componentes identificadas são (1) ressuspensão de solo, (2) aerossóis de sulfato e emissões industriais, (3) emissões veiculares, (4) emissões industriais, (5) aerossol marinho e (6) aerossol orgânico secundário. Células vazias representam ajustes que não foram estatisticamente significativos dentro de um intervalo de confiança de $95 \%$. 


\begin{tabular}{|c|c|c|c|c|c|c|}
\hline \multirow{3}{*}{ Espécie } & \multicolumn{5}{|c|}{ Fator Principal } & \multirow{3}{*}{ Percentual explicado } \\
\hline & 1 & 2 & 3 & 4 & 5 & \\
\hline & \multicolumn{5}{|c|}{ Concentracão $\left(\mu \mathrm{g} \mathrm{m}^{-3}\right)$} & \\
\hline PM2.5 & 3.27 & 2.78 & 2.35 & 0.44 & 0.64 & $99 \%$ \\
\hline $\mathrm{Al}$ & 68.92 & - & 4.54 & - & 7.64 & $103 \%$ \\
\hline $\mathrm{Si}$ & 103.92 & 7.04 & 11.54 & - & 15.05 & $97 \%$ \\
\hline $\mathrm{Ca}$ & 27.29 & 6.29 & 7.23 & 8.00 & 2.64 & $97 \%$ \\
\hline $\mathrm{Ti}$ & 8.10 & 0.31 & 1.59 & - & 0.43 & $100 \%$ \\
\hline $\mathrm{Fe}$ & 90.45 & 28.04 & 39.93 & 15.04 & - & $97 \%$ \\
\hline $\mathrm{OC}$ & 2.11 & - & 1.15 & -0.32 & 0.72 & $101 \%$ \\
\hline $\mathrm{EC}$ & 0.85 & - & 1.23 & -0.21 & 0.46 & $106 \%$ \\
\hline $\mathrm{EBC}$ & 0.76 & 0.19 & 0.97 & - & 0.20 & $96 \%$ \\
\hline $\mathrm{CO}$ & 0.14 & - & 0.14 & - & - & $92 \%$ \\
\hline NOx & 6.04 & 2.39 & 8.80 & - & 4.56 & $91 \%$ \\
\hline $\mathrm{Mg}$ & 7.94 & - & - & 6.62 & - & $81 \%$ \\
\hline $\mathrm{Na}$ & 3.23 & 31.12 & 11.14 & 39.57 & 10.57 & $99 \%$ \\
\hline $\mathrm{P}$ & 1.09 & 16.05 & 2.33 & 2.66 & 2.19 & $99 \%$ \\
\hline $\mathrm{S}$ & 24.01 & 527.14 & 78.55 & 90.25 & 54.11 & $100 \%$ \\
\hline $\mathrm{Cl}$ & 3.40 & -1.24 & 2.03 & 1.23 & 1.10 & $107 \%$ \\
\hline $\mathrm{K}$ & 88.91 & 6.46 & 36.53 & - & 5.36 & $99 \%$ \\
\hline V & 0.19 & 0.61 & 0.25 & 0.09 & 0.20 & $100 \%$ \\
\hline $\mathrm{Cr}$ & 0.30 & 0.29 & 0.48 & - & 0.08 & $97 \%$ \\
\hline $\mathrm{Mn}$ & 1.64 & 1.24 & 1.39 & 0.60 & - & $96 \%$ \\
\hline $\mathrm{Ni}$ & 0.20 & 0.29 & 0.42 & 0.07 & 0.15 & $100 \%$ \\
\hline $\mathrm{Cu}$ & 2.08 & 0.92 & 2.56 & 0.45 & 0.30 & $99 \%$ \\
\hline $\mathrm{Zn}$ & 4.56 & 11.64 & 10.88 & 6.06 & 2.58 & $99 \%$ \\
\hline As & 0.10 & 0.20 & 0.13 & 0.13 & - & $94 \%$ \\
\hline $\mathrm{Se}$ & 0.45 & 0.84 & 0.52 & - & _ & $82 \%$ \\
\hline $\mathrm{Br}$ & 1.22 & - & 1.01 & 0.57 & - & $95 \%$ \\
\hline $\mathrm{Pb}$ & 2.09 & 2.50 & 3.62 & 2.11 & - & $105 \%$ \\
\hline $\mathrm{Na}^{+}(\mathrm{IC})$ & - & 36.72 & 10.31 & 53.86 & 14.78 & $96 \%$ \\
\hline $\mathrm{K}^{+}(\mathrm{IC})$ & 76.96 & - & 31.92 & - & 5.91 & $99 \%$ \\
\hline $\mathrm{Mg}^{2+}(\mathrm{IC})$ & 2.58 & 2.40 & - & 4.56 & 1.13 & $95 \%$ \\
\hline $\mathrm{Ca}^{2+}$ (IC) & 23.86 & 4.88 & 5.38 & 7.36 & 2.67 & $98 \%$ \\
\hline $\mathrm{NH}_{4}{ }^{+}$(IC) & - & 604.28 & 67.51 & 50.60 & 43.94 & $100 \%$ \\
\hline acetato & 24.57 & 15.97 & - & - & 69.53 & $95 \%$ \\
\hline Formiato & - & 17.87 & -12.68 & 4.07 & 58.16 & $106 \%$ \\
\hline $\mathrm{Cl}^{-}(\mathrm{IC})$ & - & 1597.62 & 189.71 & 281.82 & 154.57 & $98 \%$ \\
\hline $\mathrm{NO}_{3}^{-}$(IC) & 16.96 & 17.53 & 18.92 & 13.17 & 43.17 & $98 \%$ \\
\hline $\mathrm{SO}_{4}^{2-}$ & - & 1597.62 & 189.71 & 281.82 & 154.57 & $98 \%$ \\
\hline Oxalato & 20.10 & 34.70 & 14.30 & 5.29 & 32.03 & $98 \%$ \\
\hline
\end{tabular}

Tabela A-2 - Concentrações absolutas discriminadas em cada uma das cinco fontes de material particulado retidas na análise de fatores principais na fração fina para a estação IFP. As concentrações são dadas em $\mathrm{ng} \mathrm{m}^{-3}$, à exceção das variáveis $\mathrm{OC}, \mathrm{EC}, \mathrm{EBC}$ e $\mathrm{PM}_{2.5}$, expressas em $\mu \mathrm{g} \mathrm{m}^{-3}$, e dos gases $\mathrm{CO}$ e $\mathrm{NO}_{\mathrm{x}}$, em ppm. As concentrações destacadas em negrito indicam as contribuições majoritárias. $\mathrm{O}$ percentual explicado indica a razão entre a soma das atribuições e o valor medido. As componentes identificadas são (1) ressuspensão de solo e emissões veiculares, (2) emissões industriais e de sulfato, (3) emissões veiculares, (4) aerossol marinho e (5) aerossol orgânico secundário. Células vazias representam ajustes que não foram estatisticamente significativos dentro de um intervalo de confiança de $95 \%$. 


\begin{tabular}{|c|c|c|c|c|c|c|}
\hline \multirow{3}{*}{ Espécie } & \multicolumn{5}{|c|}{ Fator Principal } & \multirow{3}{*}{ Percentual Explicado } \\
\hline & 1 & 2 & 3 & 4 & 5 & \\
\hline & \multicolumn{5}{|c|}{ Concentração $\left(\mu \mathrm{g} \mathrm{m}^{-3}\right)$} & \\
\hline PM2.5 & 4.00 & 3.63 & 2.56 & 0.59 & 0.22 & $99 \%$ \\
\hline $\mathrm{Al}$ & 31.31 & -11.43 & 66.95 & - & 3.70 & $104 \%$ \\
\hline $\mathrm{Si}$ & 47.51 & - & 107.03 & - & 5.77 & $100 \%$ \\
\hline $\mathrm{Ca}$ & 6.57 & 16.06 & 38.09 & 8.47 & 0.76 & $98 \%$ \\
\hline $\mathrm{Ti}$ & 4.54 & - & 8.07 & - & 0.39 & $102 \%$ \\
\hline $\mathrm{Fe}$ & 104.73 & 18.15 & 155.74 & - & - & $98 \%$ \\
\hline $\mathrm{OC}$ & 1.62 & 0.61 & 1.12 & - & 0.10 & $99 \%$ \\
\hline $\mathrm{EC}$ & 1.54 & 0.12 & 0.53 & - & 0.05 & $95 \%$ \\
\hline $\mathrm{EBC}$ & 1.59 & 0.36 & 0.49 & - & 0.07 & $94 \%$ \\
\hline $\mathrm{CO}$ & 0.38 & - & 0.27 & - & 0.05 & $79 \%$ \\
\hline $\mathrm{SO} 2$ & 1.55 & 0.25 & 1.05 & 0.36 & 0.21 & $94 \%$ \\
\hline $\mathrm{NOx}$ & 39.89 & - & 15.42 & - & 3.42 & $104 \%$ \\
\hline $\mathrm{Na}$ & 14.74 & 27.31 & -2.54 & 52.88 & 2.05 & $100 \%$ \\
\hline $\mathrm{Mg}$ & - & - & 9.94 & 4.73 & - & $79 \%$ \\
\hline $\mathrm{P}$ & 2.58 & 17.00 & 2.82 & 2.67 & - & $99 \%$ \\
\hline $\mathrm{S}$ & 49.52 & 594.38 & 79.66 & 91.95 & 8.73 & $99 \%$ \\
\hline $\mathrm{Cl}$ & 5.09 & - & - & 2.71 & 0.72 & $96 \%$ \\
\hline $\mathrm{K}$ & 89.50 & -9.48 & 60.88 & 9.84 & 3.27 & $102 \%$ \\
\hline V & 0.59 & 0.53 & - & 0.14 & 0.04 & $96 \%$ \\
\hline $\mathrm{Cr}$ & 1.01 & - & 0.32 & - & - & $96 \%$ \\
\hline Mn & 2.84 & 1.36 & 1.78 & 0.59 & 0.06 & $100 \%$ \\
\hline $\mathrm{Ni}$ & 0.61 & 0.44 & - & 0.14 & 0.06 & $93 \%$ \\
\hline $\mathrm{Cu}$ & 5.62 & - & 4.53 & - & 0.18 & $92 \%$ \\
\hline $\mathrm{Zn}$ & 23.21 & 19.74 & -5.37 & 9.94 & 0.64 & $100 \%$ \\
\hline As & 0.41 & 0.30 & - & - & 0.04 & $95 \%$ \\
\hline $\mathrm{Se}$ & 1.64 & 1.03 & - & 0.51 & - & $100 \%$ \\
\hline $\mathrm{Br}$ & 1.56 & 0.33 & 0.63 & 0.79 & 0.11 & $100 \%$ \\
\hline $\mathrm{Pb}$ & 5.95 & 4.02 & - & 2.34 & - & $104 \%$ \\
\hline $\mathrm{Na}^{+}(\mathrm{IC})$ & 5.16 & 28.49 & 5.79 & 75.84 & 5.29 & $99 \%$ \\
\hline $\mathrm{K}^{+}(\mathrm{IC})$ & 77.14 & -15.94 & 48.95 & 8.47 & 4.54 & $102 \%$ \\
\hline $\mathrm{Mg}^{2+}(\mathrm{IC})$ & - & 1.82 & 4.44 & 7.74 & 0.13 & $95 \%$ \\
\hline $\mathrm{Ca}^{2+}$ (IC) & 4.19 & 15.70 & 30.97 & 8.84 & 0.77 & $97 \%$ \\
\hline $\mathrm{NH}_{4}^{+}(\mathrm{IC})$ & - & 769.32 & 61.89 & 31.29 & - & $97 \%$ \\
\hline Acetato (IC) & 32.54 & 11.12 & 16.61 & - & 9.09 & $89 \%$ \\
\hline Formiato (IC) & 15.13 & 5.23 & 11.61 & - & 4.84 & $99 \%$ \\
\hline $\mathrm{Cl}^{-}(\mathrm{IC})$ & 3.85 & - & 4.03 & 5.15 & 2.40 & $88 \%$ \\
\hline $\mathrm{NO}_{3}^{-}$(IC) & 36.16 & 22.28 & 31.45 & 12.96 & 16.97 & $98 \%$ \\
\hline $\mathrm{SO}_{4}^{2-}$ & 89.08 & 1780.38 & 217.07 & 264.86 & 35.30 & $99 \%$ \\
\hline Oxalato & 41.00 & 32.71 & 29.76 & 5.61 & 3.80 & $100 \%$ \\
\hline
\end{tabular}

Tabela A-3 - Concentrações absolutas discriminadas em cada uma das cinco fontes de material particulado retidas na análise de fatores principais na fração fina para a estação FSP. As concentrações são dadas em $\mathrm{ng} \mathrm{m}^{-3}$, à exceção das variáveis $\mathrm{OC}, \mathrm{EC}, \mathrm{EBC}$ e $\mathrm{PM}_{2.5}$, expressas em $\mu \mathrm{g} \mathrm{m}^{-3}$, e dos gases $\mathrm{CO}, \mathrm{SO}_{2}$ e $\mathrm{NO}_{\mathrm{x}}$, em ppm. As concentrações destacadas em negrito indicam as contribuições majoritárias. O percentual explicado indica a razão entre a soma das atribuições e o valor medido. As componentes identificadas são (1) emissões veiculares e ressuspensão de solo, (2) emissões industriais e de sulfato, (3) ressuspensão de solo e emissões veiculares, (4) aerossol marinho e (5) aerossol orgânico secundário. Células vazias representam ajustes que não foram estatisticamente significativos dentro de um intervalo de confiança de $95 \%$. 


\begin{tabular}{|c|c|c|c|c|c|c|}
\hline \multirow{2}{*}{ Espécie } & \multicolumn{5}{|c|}{ Fatores Principais } & \multirow{2}{*}{ Comunalidade } \\
\hline & 1 & 2 & 3 & 4 & 5 & \\
\hline Al & 0.95 & 0.02 & 0.09 & 0.09 & 0.07 & 0.93 \\
\hline $\mathbf{T i}$ & 0.94 & 0.04 & 0.17 & 0.06 & 0.06 & 0.93 \\
\hline $\mathbf{S i}$ & 0.92 & 0.08 & 0.19 & 0.11 & 0.08 & 0.91 \\
\hline $\mathrm{Ca}$ & 0.77 & 0.24 & 0.28 & 0.26 & 0.00 & 0.80 \\
\hline $\mathbf{K}$ & 0.76 & 0.07 & 0.48 & 0.14 & 0.18 & 0.86 \\
\hline $\mathrm{Ca}^{2+}(\mathrm{IC})$ & 0.75 & 0.22 & 0.25 & 0.27 & 0.11 & 0.75 \\
\hline $\mathrm{Fe}$ & 0.72 & 0.22 & 0.53 & 0.07 & -0.04 & 0.85 \\
\hline $\mathbf{K}^{+}(\mathbf{I C})$ & 0.69 & 0.00 & 0.46 & 0.13 & 0.29 & 0.78 \\
\hline $\mathrm{Cl}^{-}(\mathrm{IC})$ & 0.51 & -0.09 & 0.03 & 0.31 & 0.31 & 0.46 \\
\hline $\mathrm{SO}_{4}{ }^{2-}$ & 0.07 & 0.96 & 0.01 & 0.13 & 0.10 & 0.95 \\
\hline S & 0.08 & 0.96 & 0.07 & 0.17 & 0.05 & 0.96 \\
\hline $\mathrm{NH}_{4}^{+}(\mathrm{IC})$ & -0.01 & 0.94 & 0.02 & -0.04 & 0.09 & 0.90 \\
\hline $\mathbf{P}$ & 0.12 & 0.93 & 0.08 & 0.16 & 0.06 & 0.93 \\
\hline $\mathbf{v}$ & 0.18 & 0.67 & 0.29 & 0.23 & 0.11 & 0.63 \\
\hline EBC & 0.22 & 0.04 & 0.85 & -0.08 & 0.20 & 0.83 \\
\hline EC & 0.20 & -0.15 & 0.82 & -0.08 & 0.26 & 0.82 \\
\hline $\mathrm{Cu}$ & 0.35 & 0.15 & 0.78 & 0.07 & -0.05 & 0.76 \\
\hline Mn & 0.35 & 0.48 & 0.61 & 0.21 & -0.05 & 0.78 \\
\hline $\mathbf{P b}$ & 0.11 & 0.47 & 0.61 & 0.37 & -0.01 & 0.74 \\
\hline $\mathbf{N i}$ & 0.09 & 0.50 & 0.60 & 0.24 & 0.09 & 0.68 \\
\hline $\mathrm{Cr}$ & 0.50 & 0.10 & 0.60 & 0.02 & 0.11 & 0.63 \\
\hline $\mathbf{Z n}$ & 0.01 & 0.55 & 0.57 & 0.39 & -0.02 & 0.79 \\
\hline OC & 0.55 & 0.10 & 0.57 & -0.03 & 0.32 & 0.74 \\
\hline $\mathbf{P M}_{2.5}$ & 0.49 & 0.46 & 0.53 & 0.05 & 0.23 & 0.79 \\
\hline $\mathrm{Na}^{+}(\mathrm{IC})$ & 0.34 & 0.27 & -0.02 & 0.83 & 0.15 & 0.90 \\
\hline $\mathbf{N a}$ & 0.06 & 0.43 & 0.11 & 0.83 & 0.08 & 0.89 \\
\hline $\mathrm{Mg}^{2+}(\mathrm{IC})$ & 0.55 & 0.10 & -0.06 & 0.65 & 0.05 & 0.75 \\
\hline Cl & 0.21 & 0.09 & 0.52 & 0.56 & 0.13 & 0.65 \\
\hline Formiato (IC) & 0.12 & 0.10 & -0.01 & 0.08 & 0.88 & 0.81 \\
\hline Acetato (IC) & 0.01 & 0.12 & 0.14 & 0.01 & 0.85 & 0.76 \\
\hline $\mathrm{NO}_{3}^{-}(\mathrm{IC})$ & 0.27 & 0.04 & 0.34 & 0.27 & 0.65 & 0.68 \\
\hline Oxalato (IC) & 0.39 & 0.43 & 0.32 & 0.07 & 0.52 & 0.71 \\
\hline Autovalor & 14.2 & 4.74 & 2.67 & 2.14 & 1.60 & Variância total \\
\hline Variância & $44.4 \%$ & $14.8 \%$ & $8.35 \%$ & $6.68 \%$ & $5.01 \%$ & $79.2 \%$ \\
\hline
\end{tabular}

Tabela A-4 Matriz de factor loadings da análise de fatores principais para o conjunto de dados das estações IBP, FSP e IFP na fração fina. Foram determinados 5 fatores estatisticamente significantes, explicando $79.2 \%$ da variabilidade original. Os valores em negrito indicam as associações majoritárias. São apresentadas, também as comunalidades associadas às 34 variáveis entradas no modelo. As componentes identificadas são (1) emissões veiculares e ressuspensão de solo, (2) emissões industriais e de sulfato, (3) emissões veiculares, (4) aerossol marinho e (5) aerossol orgânico secundário. 


\begin{tabular}{|c|c|c|c|c|c|c|}
\hline \multirow{3}{*}{ Emissões } & \multicolumn{5}{|c|}{ Fator Principal } & \multirow{3}{*}{ Percentual explicado } \\
\hline & 1 & 2 & 4 & 5 & 6 & \\
\hline & \multicolumn{5}{|c|}{ Concentração $\left(\mu \mathrm{g} \mathrm{m}^{-3}\right)$} & \\
\hline PM2.5 & 2.04 & 3.33 & 4.07 & 0.25 & 1.00 & $98 \%$ \\
\hline $\mathrm{Al}$ & 93.48 & 0.00 & 8.30 & 6.02 & 4.83 & $107 \%$ \\
\hline $\mathrm{Si}$ & 106.99 & 10.95 & 34.63 & 9.65 & 8.03 & $101 \%$ \\
\hline $\mathrm{Ca}$ & 22.76 & 13.63 & 16.61 & 6.67 & 0.00 & $97 \%$ \\
\hline $\mathrm{Ti}$ & 9.97 & 0.00 & 2.79 & 0.41 & 0.44 & $100 \%$ \\
\hline $\mathrm{Fe}$ & 77.49 & 42.28 & 102.07 & 6.88 & 0.00 & $101 \%$ \\
\hline $\mathrm{OC}$ & 0.94 & 0.35 & 1.75 & 0.00 & 0.55 & $100 \%$ \\
\hline EC & 0.26 & -0.16 & 1.71 & -0.05 & 0.32 & $97 \%$ \\
\hline $\mathrm{EBC}$ & 0.27 & 0.20 & 1.65 & 0.00 & 0.25 & $98 \%$ \\
\hline $\mathrm{CO}$ & 0.09 & 0.06 & 0.40 & 0.00 & 0.00 & $91 \%$ \\
\hline NOx & 3.56 & 0.00 & 28.71 & 0.00 & 2.69 & $98 \%$ \\
\hline $\mathrm{Mg}$ & 6.75 & 0.74 & 1.33 & 4.74 & 1.25 & $99 \%$ \\
\hline $\mathrm{Na}$ & 4.28 & 39.70 & 12.57 & 36.06 & 4.99 & $98 \%$ \\
\hline $\mathrm{P}$ & 1.62 & 19.57 & 2.11 & 1.75 & 0.77 & $99 \%$ \\
\hline $\mathrm{S}$ & 32.71 & 645.10 & 58.35 & 57.28 & 21.77 & $99 \%$ \\
\hline $\mathrm{Cl}$ & 0.83 & 0.00 & 3.77 & 2.07 & 0.43 & $101 \%$ \\
\hline K & 64.66 & 2.38 & 66.34 & 8.11 & 12.44 & $103 \%$ \\
\hline V & 0.12 & 0.81 & 0.32 & 0.13 & 0.06 & $102 \%$ \\
\hline $\mathrm{Cr}$ & 0.35 & 0.11 & 0.74 & 0.00 & 0.08 & $99 \%$ \\
\hline $\mathrm{Mn}$ & 0.86 & 1.95 & 2.65 & 0.43 & -0.12 & $100 \%$ \\
\hline $\mathrm{Ni}$ & 0.04 & 0.46 & 0.59 & 0.11 & 0.04 & $102 \%$ \\
\hline $\mathrm{Cu}$ & 1.42 & 1.20 & 5.43 & 0.27 & 0.00 & $99 \%$ \\
\hline $\mathrm{Zn}$ & 0.00 & 18.09 & 19.82 & 6.42 & 0.00 & $103 \%$ \\
\hline As & 0.00 & 0.20 & 0.23 & 0.11 & 0.00 & $105 \%$ \\
\hline $\mathrm{Se}$ & 0.26 & 1.00 & 1.08 & 0.29 & 0.00 & $102 \%$ \\
\hline $\mathrm{Br}$ & 0.51 & 0.58 & 1.45 & 0.55 & 0.08 & $102 \%$ \\
\hline $\mathrm{Pb}$ & 0.44 & 3.87 & 5.45 & 1.59 & 0.00 & $105 \%$ \\
\hline $\mathrm{Na}^{+}(\mathrm{IC})$ & 27.49 & 38.97 & 0.00 & 54.07 & 12.96 & $97 \%$ \\
\hline $\mathrm{K}^{+}(\mathrm{IC})$ & 53.99 & -7.54 & 58.38 & 6.66 & 21.04 & $103 \%$ \\
\hline $\mathrm{Mg}^{2+}(\mathrm{IC})$ & 5.41 & 2.75 & 0.00 & 5.13 & 0.83 & $93 \%$ \\
\hline $\mathrm{Ca}^{2+}(\mathrm{IC})$ & 19.33 & 11.83 & 13.76 & 6.16 & 3.61 & $97 \%$ \\
\hline $\mathrm{NH}_{4}^{+}$(IC) & 0.00 & 767.34 & 26.11 & 0.00 & 48.58 & $101 \%$ \\
\hline Acetato (IC) & 0.00 & 12.66 & 16.00 & 0.00 & 53.20 & $98 \%$ \\
\hline Formiato (IC) & 4.79 & 5.83 & 0.00 & 2.34 & 35.56 & $105 \%$ \\
\hline $\mathrm{Cl}^{-}(\mathrm{IC})$ & 14.85 & -4.57 & 0.00 & 7.54 & 8.86 & $96 \%$ \\
\hline $\mathrm{NO}_{3}^{-}$(IC) & 16.83 & 0.00 & 36.94 & 13.73 & 39.40 & $97 \%$ \\
\hline $\mathrm{SO}_{4}{ }^{2-}$ & 99.43 & 1994.11 & 69.11 & 146.41 & 128.51 & $99 \%$ \\
\hline Oxalato & 19.78 & 36.71 & 29.48 & 3.23 & 25.33 & $99 \%$ \\
\hline
\end{tabular}

Tabela A-5 - Concentrações absolutas discriminadas em cada uma das cinco fontes de material particulado retidas na análise de fatores principais na fração fina para o conjunto de dados das estações IFP, IBP e FSP. As concentrações são dadas em ng m ${ }^{-3}$, à exceção das variáveis $\mathrm{OC}, \mathrm{EC}, \mathrm{EBC}$ e $\mathrm{PM}_{2.5}$, expressas em $\mu \mathrm{g} \mathrm{m}^{-3}$, e dos gases $\mathrm{CO}, \mathrm{SO}_{2}$ e $\mathrm{NO}_{\mathrm{x}}$, em ppm. As concentrações destacadas em negrito indicam as contribuições majoritárias. $\mathrm{O}$ percentual explicado indica a razão entre a soma das atribuições e o valor medido. As componentes identificadas são (1) emissões veiculares e ressuspensão de solo, (2) emissões industriais e de sulfato, (3) emissões veiculares, (4) aerossol marinho e (5) aerossol orgânico secundário. Células vazias representam ajustes que não foram estatisticamente significativos dentro de um intervalo de confiança de $95 \%$. 